UNIVERSIDADE ESTADUAL PAULISTA

"JÚLIO DE MESQUITA FILHO"

Faculdade de Filosofia e Ciências - Campus de Marília

MICHELE OLIVEIRA DA SILVA

PROTOCOLO PARA PRESCRIÇÃO OU ADAPTAÇÃO DE RECURSOS PEDAGÓGICOS PARA ALUNOS COM PARALISIA CEREBRAL 
UNIVERSIDADE ESTADUAL PAULISTA

"JÚLIO DE MESQUITA FILHO"

Faculdade de Filosofia e Ciências - Campus de Marília

MICHELE OLIVEIRA DA SILVA

PROTOCOLO PARA PRESCRIÇÃO OU ADAPTAÇÃO DE RECURSOS PEDAGÓGICOS PARA ALUNOS COM PARALISIA CEREBRAL

Exame geral de defesa apresentada à Universidade Estadual Paulista "Júlio de Mesquita Filho" como parte dos requisitos para a obtenção do título de Mestre em Educação.

Área de concentração 1: Ensino na Educação Brasileira.

Linha de Pesquisa: Educação Especial no Brasil.

Orientador: Prof. Dr. Eduardo José Manzini 
Ficha Catalográfica

Serviço de Biblioteca e Documentação - UNESP - Campus de Marília

\begin{tabular}{|l} 
Silva, Michele Oliveira da. \\
S586p protocolo para prescrição ou adaptação de recursos \\
pedagógicos para alunos com paralisia cerebral / Michele \\
Oliveira da Silva. - Marília, 2010. \\
195 f. ; $30 \mathrm{~cm}$. \\
Dissertação (Mestrado em Educação) - Faculdade de \\
Filosofia e Ciências, Universidade Estadual Paulista, 2010. \\
Bibliografia: f. 108-120. \\
Orientador: Prof. Dr. Eduardo José Manzini. \\
1. Educação especial. 2. Paralisia cerebral nas crianças. 3. \\
Avaliação. 4. Aluno com paralisia cerebral. I. Autor. II. \\
Título. \\
CDD 371.9
\end{tabular}


MICHELE OLIVEIRA DA SILVA

\title{
PROTOCOLO PARA PRESCRIÇÃO OU ADAPTAÇÃO DE RECURSOS PEDAGÓGICOS PARA ALUNOS COM PARALISIA CEREBRAL
}

\author{
Dissertação apresentada à Universidade Estadual Paulista \\ "Júlio de Mesquita Filho" como parte dos requisitos para a \\ obtenção do título de Mestre em Educação. \\ Área de concentração: Ensino na Educação Brasileira. \\ Linha de Pesquisa: Educação Especial no Brasil. \\ Orientador: Prof. Dr. Eduardo José Manzini
}

Dissertação para a obtenção do título de Mestre em Educação.

Data da aprovação: 10/02/2010

COMISSÃO EXAMINADORA

Presidente e Orientador:

Prof. Dr. Eduardo José Manzini

Prof. do Departamento de Educação Especial, da Faculdade de Filosofia e Ciências - Unesp - Marília-SP.

Membro titular:

Dr. Rita de Cássia Tibério Araújo

Prof. do Departamento de Educação Especial, da Faculdade de Filosofia e Ciências - Unesp - Marília-SP.

Membro titular:

Prof. Dr. Eucia Beatriz Lopes Petean

Prof. do Departamento de Psicologia e Educação, da Faculdade de Filosofia Ciências e Letras de Ribeirão Preto.

Local: Universidade Estadual Paulista

Faculdade de Filosofia e Ciências

UNESP - MARÍLIA-SP. 


\section{Dedicatória}

Dedico este trabalho em primeiro lugar a Deus.

À minha mãe e ao meu pai que são os amores da minha vida.

Ao meu irmão, que mesmo distante está sempre presente.

Ao meu namorado Eduardo por entender as minhas ausências e oferecer o seu amor. 


\section{Agradecimentos}

Ao meu orientador Prof. Dr. Eduardo José Manzini, por me guiar neste trabalho, o meu profundo agradecimento.

À Prof. Dr. Lígia Presumido Braccialli, à Prof. Dr. Rita de Cássia Tibério e à Prof. Dr. Eucia Beatriz Lopes Petean pelas valiosas sugestões para a elaboração e finalização deste trabalho.

Aos professores Dr. Débora Deliberato, Dr. Dagoberto Buin Arena e Dr. Sadao Omote.

Às minhas amigas e amigos companheiros de caminhada, que tomaram outros caminhos, Vanessa, Mara, Milena, Fernada, Joyce, Raquel, Aldine, Walkiria, Daniel e Carlos.

Às minhas amigas, companheiras de caminhada, Priscila e Maria Luisa. A primeira há mais tempo, me dando apoio de sua amizade, a segunda, há um tempo mais recente, mas igualmente querida!

À minha irmã escolhida Giseli e a "dona Maria", por me acolherem em sua casa e me adotarem como membro de sua família. E à minha amiga Michele e seus familiares, por serem tão especiais na minha vida.

Agradeço à minha amiga Rosana, pelos anos de companhia, alegria e incentivo.

À minha amiga Mariana, e a todos os amigos de Santa Cruz do Rio Pardo que souberam entender a minha ausência e conservar a amizade.

À minha amiga e professora Nilda Roder (necessariamente nesta ordem) que me acompanha desde a época do vestibular e é meu exemplo de vida, por sua dedicação e amor à educação.

Aos membros do grupo de pesquisa "Deficiência física e sensoriais", pela amizade e contribuição para este trabalho.

Aos nossos alunos! Por tornar meu trabalho como professora da área de educação especial tão prazeroso.

A Fapesp (Fundação de Amparo a Pesquisa do Estado de São Paulo) pelo apoio financeiro que permitiu a minha dedicação exclusiva a elaboração deste trabalho.

\section{Deus capacita-me para a realização da sua obra! Ao seu nome, meu eterno louvor. Obrigada!}




\section{RESUMO}

SILVA, Michele Oliveira da. Protocolo para prescrição ou adaptação de recursos pedagógicos para alunos com paralisia cerebral. 2009. 195 f. Dissertação (Mestrado em Educação) - Faculdade de Filosofia e Ciências, Universidade Estadual Paulista, Marília, 2010.

Alguns dos critérios para garantir o acesso educacional ao aluno com paralisia cerebral são: adequar os recursos pedagógicos, favorecer a interação social, adequar o mobiliário e favorecer as oportunidades de ensino oferecidas no ambiente da sala de aula. Especificamente nos casos em que os recursos pedagógicos não são acessíveis aos alunos, é necessário adaptálos para atender às suas necessidades e potencialidades educacionais. Nesse contexto, antes de adaptar um recurso pedagógico e planejar estratégias de ensino é necessário avaliar: 1) as características do aluno: características motoras, cognitivas, sensoriais, sociais, preferências individuais e familiares; 2) características do contexto da sala de aula. Dessa maneira, essa pesquisa teve o objetivo de elaborar um instrumento para a prescrição e adaptação de recursos pedagógicos para o ensino do aluno com paralisia cerebral, destinado ao profissional da área de educação especial. Participaram desta pesquisa, onze estudantes do quarto ano de pedagogia da Habilitação em Educação Especial, área de deficiência física e quatro profissionais da área da educação especial. O instrumento foi elaborado em quatro versões. A primeira versão foi usada por um grupo de cinco estudantes. A discussão com esses participantes resultou na construção da segunda versão. A segunda versão foi usada por outro grupo de seis estudantes e por dois profissionais da área de educação especial na avaliação de uma aluna com paralisia cerebral matriculada na segunda série do Ensino Fundamental. Após a discussão da aplicação do segundo grupo e as considerações dos profissionais, a terceira versão foi construída e analisada por outros dois profissionais da área de educação especial. A discussão da terceira versão resultou na elaboração da quarta versão. Por um lado, a realização desta pesquisa contribuiu para fornecer etapas metodológicas sobre a construção de um instrumento de avaliação dentro da área da pedagogia; por outro lado, a quarta versão do protocolo configurou-se em um instrumento para auxiliar o profissional da área de educação especial na avaliação não só do aluno com paralisia cerebral, mas também de suas preferências individuais e das características do ambiente da sala de aula, resultando em dados que direcionam a prescrição ou adaptação de recurso pedagógico para o aluno com paralisia cerebral.

PALAVRAS CHAVE: Educação especial. Avaliação. Aluno com paralisia cerebral. 


\begin{abstract}
SILVA, Michele Oliveira da. Protocol for prescription or adaptation of teaching resources for students with cerebral palsy. 2009. $195 \mathrm{f}$. Dissertation (Master in Education) Universidade Estadual Paulista, Faculdade de Filosofia e Ciências, Marília, 2010.

Some of the criteria to ensure educational access for students with cerebral palsy are adequate teaching resources, promote social interaction; match the furniture and encourage educational opportunities offered in the environment of the classroom. Specifically where teaching resources are not accessible to students, it is necessary to adapt them to suit your needs and educational possibilities. In this context, before adapting a teaching resource planning and teaching strategies need to be assessed: 1) student characteristics: features motor, cognitive, sensory, social, individual and family preferences, 2) characteristics of the context of the classroom. Thus, this study aims to develop an instrument for the prescription and adjustment of teaching resources for teaching students with cerebral palsy, for the professional field of special education. Participants were eleven students in the fourth year of teaching of Special Education, area of disability and four professionals in the field of special education. It was developed in four versions. The first version was used by a group of five students. The discussion with the participants resulted in the construction of the second version. The second version was used by another group of six students and two professionals in the field of special education in the assessment of a student with cerebral palsy enrolled in second grade of elementary school. After discussing the application of the second group and the considerations of professionals, the third version was built and analyzed by two other professionals in the field of special education. The discussion of the third version resulted in the elaboration of the fourth version. First, the development of this research has helped to provide methodological steps on the construction of an assessment tool within the area of pedagogy on the other hand, the fourth version of the protocol is configured on an instrument to assist the professional in the field of education special assessment not only of students with cerebral palsy, but their individual preferences and characteristics of the environment of the classroom, resulting in data related to prescription or adaptation of teaching resource for students with cerebral palsy.
\end{abstract}

Keywords: Special Education. Assessment. Student with cerebral palsy. 


\section{SUMÁRIO}

$\begin{array}{ll}1 \text { INTRODUÇÃO } & 10\end{array}$

2 FUNDAMENTAÇÃO TEÓRICA 12

2.1 Aluno com paralisia cerebral matriculado no ensino regular $\quad 12$

2.2 Atuação do professor do ensino regular e do profissional especializado em 15 educação especial

2.3 Adaptação do recurso pedagógico 17

2.4 Relações entre as características do recurso e as características do aluno

2.5 Avaliação 23

2.5.1 Avaliações necessárias para adaptação do recurso pedagógico para o aluno $\quad 26$ com paralisia cerebral

2.5.2 Aprendizagem e planejamento de ensino $\quad 27$

2.5.3 Estratégias no ensino de alunos com paralisia cerebral 30

2.5.4 Avaliação: Área acadêmica $\quad 34$

2.5.5 Avaliação: Habilidades de comunicação 36

2.5.6 Avaliação: membro superior $\quad 37$

$\begin{array}{ll}\text { 2.5.7 Avaliação: sensorial } & 38\end{array}$

2.5.8 Avaliação: posicionamento 41

2.5.9 Avaliação: contexto social 45

2.6 Avaliação: uso do computador $\quad 46$

2.6.1 Importância da avaliação para a adaptação do recurso pedagógico 48

$\begin{array}{ll}3 \text { OBJETIVO } & 50\end{array}$

4 DESENVOLVIMENTO DAS QUATRO VERSÕES DO INSTRUMENTO DE 51 AVALIAÇÃO

$\begin{array}{ll}\text { 4.1 Participantes } & 51\end{array}$

4.2 Contexto do desenvolvimento das três versões do instrumento de avaliação

5 CONSTRUÇÃO DA PRIMEIRA VERSÃO DO INSTRUMENTO DE AVALIAÇÃO 53 
5.2 Aplicação da primeira versão do instrumento 56

5.3 Avaliação da primeira versão do instrumento $\quad 57$

5.4 Reformulação da primeira versão para a construção da segunda versão 58

6 APLICAÇÃO DA SEGUNDA VERSÃO DO INSTRUMENTO $\quad 84$

6.1 Aplicação da segunda versão do instrumento pelas participantes $\quad 84$

6.1.1 Avaliação da segunda versão do instrumento pelas participantes

6.2 Avaliação de uma aluna com paralisia cerebral matriculada no segundo ano do Ensino Fundamental

6.2.1 Dados da avaliação da aluna

6.2.2 Áreas que necessitam de intervenção e sugestões de estratégias para a aluna avaliada

7 CONSTRUÇÃO DA TERCEIRA VERSÃO DO INSTRUMENTO

7.1 Contribuições das participantes para a construção da terceira versão do 93 instrumento

7.2 Contribuições dos pesquisadores para a construção da terceira versão do instrumento

7.3 Análise da terceira versão do instrumento por profissionais da área da educação especial

8 CONSTRUÇÃO DA QUARTA VERSÃO DO INSTRUMENTO

REFERÊNCIAS

APÊNDICE A - Guia para utilização do instrumento

APÊNDICE B - Protocolo para prescrição ou adaptação de recurso pedagógico para aluno com paralisia cerebral 


\section{INTRODUÇÃO}

O primeiro contato com alunos diagnosticados com paralisia cerebral surgiu após a conclusão do curso de pedagogia, na Habilitação em Deficiência Física na área da Educação Especial na Faculdade de Filosofia e Ciências - UNESP- Campus de Marília.

Nessa ocasião, como parte integrante da carga horária da Habilitação, havia o horário do estágio que era dividido entre o atendimento educacional de alunos com deficiência física, em um centro de atendimento especializado e em uma sala para deficientes físicos em uma escola estadual.

Para a conclusão de uma das disciplinas, foi necessária a elaboração de um recurso pedagógico adaptado para um aluno do estágio. Diante dessa situação, percebeu-se que avaliar as características físicas, cognitivas e sociais do aluno com deficiência física, particularmente os diagnosticados com paralisia cerebral, não era fácil.

No início da disciplina, observaram-se diversas situações nesse sentido: algumas vezes, a avaliação era incompleta, por exemplo, avaliava-se a característica motora e cognitiva e não a característica social; outras vezes, a avaliação resultava em um amontoado de dados dificultando a identificação da potencialidade e da necessidade do aluno, que, na maioria das vezes, pouco contribuía para a adaptação do recurso; ou ainda, as dificuldades motoras do aluno com deficiência física eram mais evidenciadas do que as suas potencialidades. Ao final da disciplina, as dificuldades em avaliar o aluno eram minimizadas, mas permanecia a dificuldade em sistematizar esses dados de maneira organizada para auxiliar na escolha dos materiais para a adaptação do recurso pedagógico.

Após a conclusão da Habilitação, a experiência escolar como docente no ensino fundamental comprovou que a dificuldade em avaliar o aluno para adaptar o recurso pedagógico era uma realidade na rotina dos professores (com ou sem formação em educação especial) e na rotina de qualquer outro profissional da área de Educação Especial.

Observou-se que, por um lado, o professor sem formação em educação especial não conseguia adaptar recursos pedagógicos dentro da perspectiva básica do currículo, pois havia dificuldades para avaliar as habilidades e potencialidades individuais do aluno com deficiência.

Por outro lado, avaliar dimensões tão precisas sobre as capacidades e necessidades do aluno com paralisia cerebral era um processo demorado e cansativo, mesmo para os 
profissionais da área de Educação Especial, visto que esses profissionais não tinham nenhum instrumento que pudesse direcionar essa avaliação em virtude da necessidade de adaptar um recurso pedagógico.

Diante disso, levantou-se a hipótese de que se houvesse um instrumento de avaliação para avaliar as características específicas do aluno, englobando, inclusive, características do seu contexto escolar e a coleta de dados sobre os seus familiares, esse instrumento auxiliaria o profissional da área de educação especial na prescrição ou adaptação do recurso pedagógico para alunos com paralisia cerebral dentro do contexto da educação inclusiva.

Pensando nisso, colocou-se o seguinte problema de pesquisa:

Seria possível desenvolver um instrumento de avaliação para auxiliar o profissional da área de Educação Especial na prescrição de recursos pedagógicos para atingir os objetivos de ensino e atender às necessidades educacionais de alunos com paralisia cerebral?

Quais itens seriam necessários incorporar neste instrumento?

Qual conteúdo o instrumento deveria conter? 


\section{FUNDAMENTAÇÃO TEÓRICA}

Nesta seção, serão apresentadas as fundamentações teóricas sobre: 1) o aluno com paralisia cerebral matriculado no ensino regular; 2) atuação do professor do ensino regular e do profissional especializado em Educação Especial; 3) adaptação do recurso pedagógico; 4) relações entre as características do recurso e as características do aluno; 5) avaliação; 6) avaliações necessárias para adaptação do recurso pedagógico para o aluno com paralisia cerebral e 7) importância da avaliação para a adaptação do recurso pedagógico.

\subsection{Aluno com paralisia cerebral matriculado no ensino regular}

Após 16 anos da reafirmação do direito de todas as pessoas à educação, por meio da Declaração de Salamanca, o sistema educacional brasileiro ainda busca caminhos para atender a um dos mais importantes pontos da educação, que é garantir uma educação de qualidade para todos (BRASIL, 1994).

No Brasil, o documento nacional que visa direcionar o planejamento do projeto pedagógico do ensino fundamental são os Parâmetros Curriculares Nacionais (PCN). Esses materiais constituem-se como base para a construção curricular em cada etapa escolar, sendo pontos norteadores, que visam orientar o sistema de ensino do país.

É um documento flexível que deve ser adaptado a diferentes situações econômicas e políticas de acordo com cada região brasileira.

Neles, o professor encontra uma lista de objetivos pedagógicos para cada série do Ensino Fundamental, além disso, há sugestões pedagógicas para embasar o planejamento da aula, como, por exemplo, atividades que podem ser realizadas para alcançar determinados objetivos de ensino, materiais pedagógicos e estratégias de ensino (BRASIL, 2000).

Assim, os PCNs são concebidos como ferramentas norteadoras da educação brasileira, que orientam e ampliam o conhecimento do professor em relação ao ensino das matérias do Ensino Fundamental.

Sabe-se, porém, que o conteúdo desses materiais é apenas sugestivo, e é função do professor, adaptar o ensino conforme as necessidades dos alunos, considerando os aspectos 
regionais, estaduais e políticos para promover o ensino de diferentes conteúdos, para todos da sala de aula.

Nos casos dos alunos com paralisia cerebral (P.C.), matriculados no Ensino Fundamental, além dessas considerações, o professor terá de promover o acesso físico à atividade, pois, devido às limitações motoras, nem sempre os materiais pedagógicos são acessíveis a esses alunos.

Sabe-se, por exemplo, que qualquer alteração que impeça o funcionamento adequado da linguagem oral e/ou escrita, por serem as vias mais tradicionais de comunicação, pode dificultar o processo de ensino e aprendizagem (SMITH; RYNDAK, 1999).

Além das limitações motoras que são as características mais evidentes nos alunos com paralisia cerebral (GIANNI, 2003), há outras características que podem influenciar no ensino desses alunos, como definiu Souza (2005, p.51):

Paralisia Cerebral descreve um grupo de desordens do movimento e da postura, causando limitação de atividades, que são devidas a alterações não progressivas que ocorreram no cérebro fetal ou infantil. As desordens motoras da paralisia cerebral frequentemente estão acompanhadas por alterações sensoriais, na cognição, comunicação, percepção, comportamento e/ou crises convulsivas.

Além disso, há classificações que permitem identificar o tipo de paralisia cerebral de acordo com o tônus muscular, o grau de comprometimento motor e a distribuição topográfica ${ }^{1}$.

No entanto, como observado por Gauzzi e Fonseca (2004), essas classificações podem diferenciar-se de autor para autor. Dessa maneira, as classificações descritas no presente estudo, seguem definições determinadas.

Para os autores, Sposito e Fonseca (2004) e Gianni (2010), a classificação de paralisia cerebral foi definida como: espástica, discinética (atetóide, coréico, distônico), atáxica e mista. No entanto, há autores (GAUZZI; FONSECA, 2004; SCHWARTZWAN, 2004) que acrescentam a essa definição a classificação hipotônica.

O tipo de paralisia classificada como espástica é a mais comum e se caracteriza principalmente pelo aumento do tônus muscular, que, como consequência, pode contribuir para o aumento do aparecimento de deformidades.

A discinética tem como característica principal a presença de movimentos involuntários. A atáxica, a incoordenação dos movimentos de origem cerebelar, ataxia de tronco quando sentado e dismetria e incoordenação motora.

\footnotetext{
${ }^{1}$ Refere-se à classificação topográfica aquela que descreve o grau de comprometimento motor e os membros comprometidos.
} 
A paralisia cerebral hipotônica é caracterizada pela diminuição do tônus muscular, geralmente temporária, diminuição da força muscular e instabilidade postural.

A paralisia cerebral mista é caracterizada pelo não predomínio de nenhuma das formas piramidais ou extrapiramidais, apresentando uma associação de alterações entre esses dois tipos.

Há, ainda, uma classificação em relação à distribuição topográfica dos membros, que pode ser: diplegia - membros inferiores mais comprometidos do que os membros superiores; hemiplegia - membro superior e membro inferior de um lado do corpo comprometidos; quadriplegia - membros superiores mais comprometidos do que os membros inferiores, além do comprometimento de controle de tronco e cabeça.

É importante para o professor conhecer essa classificação para que ele possa reconhecer as características dos alunos diagnosticados com a paralisia cerebral, e, em seguida, escolher o recurso pedagógico mais acessível às suas possibilidades motoras, cognitivas e sociais.

No entanto, apenas conhecer a classificação não é suficiente para identificar as necessidades e potencialidades específicas de cada aluno.

Isso se deve ao fato de que, apesar de os distúrbios motores e posturais serem características gerais de qualquer tipo de P. C., não há características padronizadas entre os sujeitos, ou seja, cada sujeito possui características próprias em relação às características motoras, sensoriais e/ou cognitivas (MILLER; CLARK, 2002).

Dessa forma, mesmo que haja mais de um aluno com o mesmo diagnóstico de paralisia cerebral, é preciso que as atividades de ensino sejam planejadas de acordo com as características individuais de cada aluno.

No contexto do ensino regular, há diversos fatores que podem dificultar a aprendizagem do aluno com paralisia cerebral, como, por exemplo, a falta de acessibilidade física ao material pedagógico, a falta de planejamento de atividades que correspondam às necessidades dos alunos e a falta de condições no ambiente escolar que favoreçam a inclusão.

Alpino (2008) descreveu determinados aspectos como necessários para fornecer condições acessíveis ao ensino do aluno com paralisia cerebral: disponibilização de professores capacitados para auxiliar o ensino desses alunos, materiais pedagógicos e equipamentos adaptados, retirada de barreiras arquitetônicas, além de disponibilização de mobiliário escolar adequado. 


\subsection{Atuação do professor do ensino regular e do profissional especializado em educação especial}

A matrícula de alunos com deficiência no ensino regular requer formação, sensibilidade e compromisso para que o professor consiga planejar suas aulas levando em consideração as características de cada aluno.

A prática pedagógica é comprometida no momento em que o professor, ao se deparar com um aluno com severos comprometimentos motores, passa a não acreditar que seja possível o ensino desse aluno junto aos demais no ensino regular, antes mesmo, de conhecer suas capacidades (MELO; MARTINS, 2004).

No caso específico dos alunos com paralisia cerebral, o professor, sem conhecimento específico, pode ficar frustrado ao tentar trabalhar com eles e não conseguir fazê-lo adequadamente, pois, na maioria das vezes, suas potencialidades são camufladas pelas limitações motoras (NUNES, 2007).

Para Reganhan (2006), essas dificuldades podem ser atribuídas à falta de uma formação continuada com enfoque no ensino do aluno com deficiência e à falta de assessoria de professores especializados em educação especial.

Assim, há necessidade de uma parceria entre os profissionais especializados em educação especial da área da saúde e da educação e o professor do ensino regular, para garantir um ensino adequado às necessidades desses alunos no ensino comum (CACCIARI; DE LIMA; BERNARDI, 2005; SILVA, 2007; ALPINO, 2008; RAMOS; ALVES, 2008; SAMESHIMA; RODRIGUES; DELIBERATO, 2009). Entre esses profissionais, destaca-se a atuação do professor especialista em parceria com o professor do ensino regular (BRASIL, 1996; BALEOTTI, 2001; MARTÍN; JÁUREGUI; LÓPEZ, 2004; TEZANI, 2004; GONÇALVES, 2006; MARTINS, 2006; MENDES, 2006; PELOSI, 2006; REGANHAN, 2006; DE PAULA, 2007; MELO; MARTINS, 2007; SILVA, 2007; ALPINO, 2008; BRASIL, 2008).

O atendimento educacional especializado deve complementar a formação do aluno, podendo ser oferecido no âmbito escolar ou em locais especializados, no turno inverso ao do período escolar (BRASIL, 2008).

Nas escolas, o profissional especializado em educação especial deve apoiar o trabalho do professor da sala de aula comum, estando na sala de recurso ou colaborando com o ensino dentro da sala de aula regular. 
$\mathrm{Na}$ sala de recurso, os programas disponibilizados devem facilitar a autonomia e independência dos alunos com necessidades educacionais especiais, como, por exemplo, oferecendo programa de enriquecimento curricular, serviços de intervenção precoce para alunos da educação infantil, ações que promovam a acessibilidade arquitetônica, comunicativas (oferecer educação bilíngue contemplando a Língua Brasileira de Sinais, Língua Portuguesa, Braille e Soroban), orientação e mobilidade, comunicação alternativa, oferecer recursos e estratégias para facilitar o ensino, quando não há possibilidades do manuseio dos materiais pedagógicos, entre outros. Entende-se, assim, o atendimento na sala de recurso, como um auxílio para complementar a formação desses alunos, sem que substitua o ensino regular (GARCIA; DE ROSE, 2004; BRASIL 2008).

$\mathrm{Na}$ sala do ensino regular, espera-se que os profissionais especializados atuem em parceria com o professor do ensino comum dentro da própria sala de aula. Nessa parceria, os dois profissionais constroem o planejamento acadêmico, definem estratégias e a avaliação de cada aluno, buscando suprir as necessidades de todos (SILVA, 2007).

Para atender a essa perspectiva, o profissional especializado em educação especial precisa ter uma formação inicial ou continuada, que ofereça conhecimentos específicos da área de educação especial, capacitando-o para atuar em diferentes contextos educacionais, como:

[...] nas salas comuns do ensino regular, nas salas de recursos, nos centros de atendimento educacional especializado, nos núcleos de acessibilidade das instituições de educação superior, nas classes hospitalares e nos ambientes domiciliares, para a oferta dos serviços e recursos de educação especial (BRASIL, 2008, p. 18).

Entende-se, portanto, que a função do profissional especializado é trabalhar em colaboração com o professor do ensino regular, elaborar e organizar recursos pedagógicos e de acessibilidade que eliminem as barreiras para a plena participação dos alunos, oferecer atendimento especializado dentro e fora do ambiente escolar, propor atividades e estratégias pedagógicas que garantam o acesso de todos os alunos aos conteúdos curriculares do ensino regular, tendo em vista a necessidade específica de cada um (ALVES; GOTTI, 2006; MELO; MARTINS, 2007; BRASIL, 2008).

Assim, para garantir uma educação de qualidade para todos, inclusive para o aluno com paralisia cerebral, o profissional especializado em educação especial, em parceria com o professor do ensino regular deve fornecer condições de acessibilidade ao aprendizado do aluno, planejando atividades compatíveis com o seu nível de desenvolvimento, adaptando recursos pedagógicos e definindo estratégias de ensino. 


\subsection{Adaptação do recurso pedagógico}

Os profissionais, entre eles, o professor, sem uma formação específica e/ou uma orientação adequada, no primeiro contato com um aluno com paralisia cerebral, podem considerá-lo como um aluno incapaz de realizar determinadas atividades intelectuais (MOURA, 2004) quando, na maioria das vezes, o que ele não consegue é manipular o material pedagógico.

No entanto, se o aluno permanecer sem realizar as atividades, por não ter acesso a recursos adequados que ofereçam oportunidades de manipulação, pode vir a apresentar uma defasagem no nível de conhecimento, não por falta de capacidade, mas por falta de acessibilidade física à atividade.

Nesse contexto, apenas a garantia de matrícula desses alunos no ensino regular não deve ser considerada como inclusão (TEZANI, 2004; PADILHA, 2006), e, por isso, não se deve esperar que as crianças com deficiências matriculadas na sala de aula regular aprendam apenas pela proximidade com alunos da mesma idade (PELOSI, 2006).

Pelo contrário, é preciso oferecer um ensino direcionado ao aluno, que atenda suas necessidades pedagógicas e ofereça alternativas que contribuam para que todos tenham acesso às atividades propostas.

O decreto n.6094/07 que dispõe sobre a implementação do plano de metas e compromissos da educação, no capítulo IV da assistência técnica e financeira da união, indica que uma das metas do Ministério da Educação é garantir que as escolas tenham recursos pedagógicos para auxiliar o trabalho do professor (BRASIL, 2007).

No entanto, para o ensino dos alunos com paralisia cerebral, o professor pode ter dificuldades para usar os materiais pedagógicos disponíveis na escola, pois nem sempre as dimensões do material facilitam a sua manipulação, devido às características motoras específicas que cada aluno pode apresentar (AUDI, 2006).

Desse modo, para auxiliar a prática pedagógica do professor com o conteúdo do currículo escolar, uma das principais ações é a adaptação do recurso pedagógico.

As duas grandes finalidades para adaptar um recurso pedagógico são: garantir que o aluno consiga ter acesso à atividade, e melhorar o seu desempenho na realização das tarefas (AUDI, 2006).

$\mathrm{O}$ recurso pedagógico pode ser classificado em: pouco estruturado e muito estruturado (MANZINI, 1999; MANZINI; DELIBERATO, 2007). 
O recurso pouco estruturado permite que um mesmo recurso possa ser utilizado com diferentes objetivos e estratégias de ensino, como, por exemplo, jogo de cartas que pode ser usado com o objetivo de trabalhar com os números ou com os desenhos de cada carta. Por sua vez, um recurso muito estruturado só atende a um objetivo específico, como acontece com um jogo com peças construídas com o mesmo material, o mesmo design físico (conservando o mesmo formato, a mesma cor e o mesmo peso) e com diferentes texturas, no qual dificilmente outro objetivo além da identificação das texturas poderá ser trabalhado.

Além de garantir o desenvolvimento acadêmico, Martín, Jáuregui e López (2004) observaram que no caso de alunos com limitações motoras, que, muitas vezes, são privados da manipulação de objetos para a aquisição do conhecimento, a adaptação de recursos pedagógicos pode também prevenir novas limitações.

Pode-se concluir, então, que, desde que as adaptações atendam às necessidades do aluno com paralisia cerebral, o uso de materiais adaptados é determinante para o seu aprendizado, podendo inclusive beneficiar qualquer outro aluno da sala (MANZINI, 2005; PELOSI, 2006; MANZINI, no prelo).

Visando à importância da adaptação de recurso pedagógico, é preciso buscar na literatura a sua definição. Em um contexto educacional (com alunos com P. C.), Manzini $(1999$, p.17) descreveu que o recurso pedagógico é o instrumento mais utilizado no contexto acadêmico e o definiu como sendo um material “[...] concreto, manipulável e com objetivo pedagógico". Assim, pode-se entender por recurso pedagógico adaptado, como um material concreto que se adapta às condições motoras do aluno dentro de um objetivo pedagógico, possibilitando a sua manipulação e a realização da atividade. No entanto, deve-se entender que o recurso, por si só, não promove o ensino, sendo fundamental a presença do professor para oferecer oportunidades de aprendizagem.

Para adaptar um recurso, o professor precisa, em primeiro lugar, partir de um objetivo pedagógico diretamente relacionado com o currículo básico escolar.

Esse currículo deve abranger todas as possibilidades educacionais dos alunos, ou seja, o professor deve trabalhar com um currículo flexível, que direcione o projeto acadêmico, mas aceite mudanças e adaptações em função de determinados contextos escolares (GONZÁLEZ, 2002).

Nesse contexto inclusivo, as atividades podem apresentar diferentes níveis de complexidade, mas a meta do currículo deve ser a mesma para todos os alunos, sendo garantidas as modificações necessárias para promover o aprendizado de todos (CARVALHO, 2000). 
Dessa forma, entende-se que cada aluno tem direito a um ensino baseado no conteúdo do currículo escolar, mas com estratégias que atendam suas necessidades de aprendizagem individuais (FALVEY; GIVNER; KIMM, 2002).

Em relação ao objetivo da atividade e ao planejamento da aula, o recurso pedagógico deve ser adaptado com o intuito de proporcionar o conhecimento e a interação do aluno com o resto da sala de aula, pois, de nada adianta se o recurso pedagógico for adequado às necessidades do aluno, se não favorecer a interação dele com o resto da sala.

Nessa perspectiva, Deliberato $(2007$, p.33) concluiu que "os materiais e procedimentos adaptados devem fazer parte do contexto da sala para propiciar a participação de todos com a garantia de possibilitar a aprendizagem acadêmica".

Em 2006, Gonçalves observou alunos com paralisia cerebral matriculados na sala de aula do ensino regular. Em uma de suas observações, a autora constatou que os recursos pedagógicos adaptados para o ensino de uma aluna com paralisia cerebral se limitavam ao uso de engrossadores de lápis e canetinhas, todos com o objetivo de facilitar a preensão. No entanto, a presença desses recursos adaptados não garantiu que a aluna realizasse as atividades, pois, a autora observou que, em algumas vezes, a aluna permanecia sem fazer nada, em outras, esperava a professora instruir toda a sala para depois ser instruída para realizar a sua atividade.

Sobre esse assunto, não é raro observar alunos com grandes comprometimentos motores, cognitivos e/ou de comunicação, matriculados na sala de aula regular, sem realizar atividade alguma, ou ainda, desenvolvendo atividades sem finalidade pedagógica, mesmo em casos em que há disponibilização de recursos pedagógicos adaptados.

Schmitz (1980), em um estudo sobre o uso dos recursos pedagógicos como auxílio da prática do professor, teceu algumas considerações sobre o uso inadequado que o professor pode fazer desses instrumentos.

Observa-se que as considerações feitas por Schmitz, mesmo não sendo específicas para o uso do recurso pedagógico adaptado, contribuem diretamente para essa prática pedagógica.

Baseados em suas considerações, três aspectos são pontuados como indispensáveis para a utilização efetiva do recurso pedagógico: 1) nenhum recurso substitui o professor; 2) o recurso é um instrumento auxiliar para atingir uma finalidade pedagógica, por isso, não deve ter sua manipulação como objetivo final da atividade; 3) sua utilização não é a coisa mais fundamental na aprendizagem, mas é indispensável para que ela se realize. 
Aliados a ideia de Schmitz, devem-se considerar mais dois aspectos próprios da utilização de recursos pedagógicos adaptados: 1) o recurso só será adaptado quando houver reais necessidades e 2) a adaptação não é permanente.

Em relação ao último aspecto, acredita-se que a adaptação de um recurso pedagógico nunca será permanente, pois, há necessidade de modificação contínua para atender às características do aluno (que estão sempre se modificando) e aos diferentes objetivos pedagógicos.

Mesmo no caso em que os recursos são permanentes, como alguns recursos para comunicação alternativa, há necessidade de modificação contínua no repertório dos materiais, para atender aos diferentes ambientes sociais de que o aluno participa (DELIBERATO, 2007).

Conclui-se, então, que possuir recursos pedagógicos adaptados, por si só, não garante o acesso do aluno à atividade, podendo inclusive dificultar ou até mesmo impossibilitar sua realização, quando as adaptações não são feitas para atender às características do aluno e o contexto em que ele está inserido.

\subsection{Relações entre as características do recurso e as características do aluno}

Da mesma maneira que a simples inserção do aluno com deficiência no ensino regular não torna a escola receptiva às suas necessidades (MARTINS, 2006; BRASIL, 2008), afirma-se que, a utilização de qualquer material pedagógico não torna a atividade acessível ao aluno com deficiência.

O recurso adaptado só é um auxílio no ensino do aluno, quando as decisões para a sua adaptação são baseadas nas características do aluno e do meio escolar. Assim, se o material utilizado para adaptar o recurso não atender às necessidades do aluno, poderá não contribuir com a realização da atividade, podendo inclusive, acentuar suas limitações. Supondo que um aluno diagnosticado com paralisia cerebral, com dificuldades nos movimentos motores dos membros superiores, participa, poucas vezes, do jogo de dominó com o resto de sua sala, devido ao grande tempo que ele gasta para jogar e a frequência com que ele derruba as peças. Pensando em colaborar com o ensino desse aluno, o professor utiliza um dominó que foi adaptado para outro aluno com paralisia cerebral que havia estudado naquela escola e o utiliza com a turma. Contudo, o professor observa que o aluno passa a ter 
mais dificuldade com o manuseio do dominó adaptado do que com o dominó sem adaptação, e, por isso, retoma o uso do antigo dominó.

É possível observar nesse exemplo, que mesmo com a utilização do dominó adaptado, o recurso não favoreceu o ensino do aluno, pelo simples fato de o professor ter escolhido um recurso que foi adaptado anteriormente para outro aluno, que, mesmo tendo o mesmo diagnóstico do aluno em questão, não possuía suas necessidades e potencialidades.

Nesse contexto, Rocha e Deliberato (2008) desenvolveram um estudo com o objetivo de inserir recursos de tecnologia assistiva nas atividades pedagógicas de um aluno com deficiência física. Nele, as pesquisadoras observaram que a disponibilização de materiais pedagógicos comumente encontrados na escola não facilitava a realização das atividades, ao contrário, o uso de tais recursos fazia com que o aluno necessitasse de mais tempo para o término das tarefas, fizesse maior esforço físico e tivesse maior gasto de energia devido à dificuldade em manipulá-los, consequentemente, causando cansaço e desmotivação. No entanto, após uma avaliação detalhada sobre as necessidades do aluno e as demandas da professora, as autoras adaptaram recursos específicos para o aluno em questão, que passou a: 1) expor seus conhecimentos através de ações motoras, 2) participar ativamente do processo de aprendizagem, 3) realizar a mesma atividade no mesmo período de tempo de seus colegas, sem necessitar de tempo extra e 4) ter acesso a um número maior de estímulos, acompanhando o conteúdo desenvolvido pelo professor.

Assim, para adaptar um recurso pedagógico é preciso conhecer as características motoras, cognitivas, emocionais do aluno, e as exigências pedagógicas e sociais do meio em que ele está (ARAÚJO; MANZINI, 2001).

Em relação ao movimento dos membros superiores, observa-se que o peso do recurso, o tamanho, a forma podem contribuir com o movimento ou dificultá-lo na preensão e manipulação dos materiais pedagógicos (CRUZ, 2006; PAIVA, 2007).

Observa-se, então, que a incapacidade pode não ser decorrente apenas da deficiência, mas também da impossibilidade de acesso ao meio (SOUZA, 2003; BERSCH; MACHADO, 2007; BRASILEIRO; MOREIRA; JORGE, 2009).

Para tanto, as dimensões de estímulos que um recurso pode apresentar não podem ser determinadas aleatoriamente, mas, criteriosamente, visando minimizar as dificuldades físicas dos alunos, contribuindo para o manuseio de cada recurso (MANZINI; DELIBERATO, 2007). 
A literatura faz referencias a determinados tipos de materiais e metodologias, que devem ser escolhidos de acordo com as características físicas, comunicativas, visuais e cognitivas do aluno com paralisia cerebral.

Em relação às características físicas, observa-se que, para a criança com paralisia cerebral do tipo atetóide, que apresenta movimentos involuntários nos membros superiores, é indicado o uso de um material mais pesado (BRASIL, 1980; AUDI, 2006; MANZINI; DELIBERATO, 2007).

Em relação ao aluno não falante ou que possui dificuldade para se comunicar com a fala oral, utiliza-se a comunicação alternativa para proporcionar uma comunicação funcional. Para os autores Manzini e Deliberato (1999, p. 98), o uso da comunicação alternativa tem duas finalidades: “1) promover e suplementar a fala; 2) garantir uma forma alternativa de comunicação de um indivíduo que ainda não começou a falar”. Para o uso desse tipo de comunicação, os autores evidenciaram que a escolha dos materiais, como: fotografias, desenhos, sistemas de signos ou cartas, ou ainda, expressões, como gestos manuais, piscar os olhos ou outros, é realizada de acordo com as potencialidades de cada criança.

Em relação ao ensino de alunos com alterações visuais, é necessário que o professor escolha o material que permita uma melhor visualização, de acordo com suas possibilidades, podendo ser, atividades em figuras branco e preto, figuras coloridas, fotos coloridas ou em branco e preto, objetos em miniatura ou objetos em tamanho real (BRUNO, 2005).

Do mesmo modo, para alunos que ainda não conhecem letras, o professor deve escolher entre os materiais, o mais adequado às suas potencialidades, como, por exemplo, o uso de vocabulário com letras, figuras, fotos, objetos ou uma combinação entre esses (HELFER; OLIVEIRA; MIOSSO, 2005; MANZINI; DELIBERATO, 2007).

No processo de adaptação do recurso pedagógico, o aluno pode contribuir com a escolha de determinados materiais e seu design, pois o uso do recurso deve ser benéfico para os dois sujeitos da educação, ou seja, para o aluno e para o professor (MANZINI; SANTOS, 2002).

Alpino (2008) aponta três principais motivos para a recusa do aluno em utilizar o recurso, quando não há a sua participação na adaptação:

1. Questão estética: o aluno não aceita utilizar o recurso devido à aparência estética do material;

2. Questão social: o aluno não aceita utilizar o recurso devido aos valores sociais atribuídos ao seu uso; 
3. Questão funcional: o aluno não aceita utilizar o recurso devido à dificuldade em sua utilização.

Dessa maneira, o que garante que o recurso adaptado favoreça a educação do aluno é uma avaliação precisa sobre: as necessidades e capacidades do aluno, para direcionar a escolha do material mais adequado; as sugestões do aluno sobre a adaptação e o uso do recurso pedagógico; e a elaboração de atividades compatíveis com o currículo escolar da série em que ele está inserido.

\subsection{Avaliação}

A avaliação educacional permite que o professor identifique as necessidades e capacidades do aluno e, posteriormente, inicie o planejamento escolar com metas traçadas sobre o que se pretende ensinar (BRASIL, 2000; MARTÍN; JÁUREGUI; LÓPEZ, 2004; STECKER; LEMBKE; FOEGEN, 2008).

Diante disso, a avaliação favorece o processo educacional, o desenvolvimento pessoal e social do aluno (GUIJARRO, 2005).

No caso do aluno com paralisia cerebral é com a avaliação que o professor identifica as suas potencialidades e necessidades para abstrair objetivos de ensino, contemplando: uso de recursos pedagógicos e elaboração de atividades com estratégias previamente definidas (DE PAULA, 2007).

Manzini (2000a) e Alpino (2008) observaram que é necessário que haja uma avaliação envolvendo as capacidades cognitivas, habilidades da linguagem e da fala, características da área acadêmica, da área social, da área emocional, da área motora, além das características do contexto em que o aluno está inserido, para que as propostas de ensino sejam elaboradas.

A ação de avaliar não deve ter o objetivo de rotular o aluno com mais ou menos facilidade para o aprendizado, pelo contrário, deve identificar as necessidades do aluno para ter acesso à atividade, direcionando a adaptação do recurso pedagógico.

Sabe-se que, cada aluno com P. C. pode apresentar uma diversidade de alterações que lhe são específicas e, que interferem no funcionamento de diversas funções, tais como, na comunicação, que pode variar desde uma comunicação um pouco limitada até uma fala muito comprometida ou, até mesmo, sua ausência (TABITH, 1995), além de limitações 
sensoriais, visuais e/ou auditivas, associadas à limitação motora (OLIVEIRA; CORDANI, 2004; SCHWARTZWAN, 2004).

Sabe-se, ainda, que é responsabilidade do professor observar as características individuais, procurando identificar as vias de acesso para a comunicação e para a aprendizagem, para que, a partir delas, ele consiga adequar toda a metodologia de ensino para cada caso em particular (GODOI, 2001).

Nesse contexto, a avaliação desempenha funções indispensáveis em dois momentos do planejamento de ensino do aluno (MANZINI; DELIBERATO, 2007):

- No primeiro momento, antes de planejar a atividade e as estratégias de ensino, a função da avaliação é coletar dados sobre as possibilidades motoras, cognitivas, sociais e em relação à preferência individual do aluno; e identificar o quanto o ambiente externo está proporcionando acessibilidade ou dificultando o ensino do aluno;

- $\quad$ E o segundo momento, depois de realizada a atividade acadêmica, a função da avaliação é identificar se o material pedagógico contribuiu ou não para a sua manipulação; se as estratégias desenvolvidas foram adequadas para o desenvolvimento da atividade e se o objetivo pedagógico favoreceu o desenvolvimento acadêmico do aluno.

Em resumo, a avaliação do aluno é importante para o processo de adaptação e uso do recurso pedagógico, pois é a partir da avaliação que o professor adapta inicialmente o recurso; depois, identifica quando o recurso não está mais atendendo às necessidades e às potencialidades do aluno; e indica ainda, quais as novas características que as futuras adaptações deverão contemplar.

Nessa tarefa, o professor funciona como mediador entre o conhecimento e o seu aluno, e a sua função é identificar as habilidades e as necessidades educacionais especiais contrapondo aos recursos disponíveis para promover o ensino (FIGUEIREDO; MANZINI, 2002; REGANHAN, 2006).

Dutra (2006) e Delagracia (2007) concordaram com essa afirmação quando afirmaram que é preciso identificar as potencialidades e não só os déficits do aluno com paralisia cerebral.

No entanto, sem um instrumento de avaliação que direcione o olhar do profissional em educação especial e disponibilize de maneira sistematizada os dados coletados, essa tarefa pode transformar-se em um processo demorado e cansativo, e que, muitas vezes, não identifica as reais potencialidades do aluno.

Há na literatura, instrumentos destinados à avaliação a serem utilizados em situação escolar e familiar, com enfoque nos aspectos educacionais. 
$\mathrm{Na}$ área da deficiência visual, Bruno (2005) desenvolveu um instrumento de avaliação educacional para alunos da educação infantil com baixa visão e múltipla deficiência. Para a avaliação, a autora selecionou materiais e os adaptou de acordo com as necessidades da baixa visão e dificuldades neuromotoras, constituindo-se em: brinquedos com cores em alto contraste, jogos pedagógicos adaptados, fotos de objetos, figuras, silhuetas, jogos com numerais, letras, palavras, jogo de memória, quebra-cabeça, jogos de construção e livros infantis. Os materiais foram adaptados em quatro níveis de complexidade: 1) objeto real com cores em alto contraste, 2) foto colorida do objeto, 3) figura em branco e preto com a forma cheia e 4) figura esquemática. Como se trata de uma avaliação para alunos da educação infantil, a autora desenvolveu um sistema de ludo-diagnóstico, com episódios de quatro cenas lúdicas, sendo denominadas como: 1) Que tal fazer um lanche?; 2) Vamos brincar de faz de conta?; 3) Como as coisas funcionam; 4) Vamos brincar de circo ou fazenda? Com o objetivo de complementar essa avaliação, a autora desenvolveu um roteiro de entrevista semiestruturada, para identificar as competências, necessidades e dificuldades dos alunos com os seus familiares. Esse roteiro possibilita a coleta de informações sobre a história da criança, suas preferências, suas competências escolares, possibilidades para adaptação de materiais, equipamentos, estratégias de aprendizagem e expectativas dos pais em relação aos filhos.

$\mathrm{Na}$ área da comunicação, De Paula, em 2007, desenvolveu um protocolo para que profissionais da saúde e da educação pudessem avaliar as habilidades comunicativas de alunos não falantes em ambiente escolar. No mesmo ano, Delagracia (2007) desenvolveu um protocolo para avaliar as habilidades comunicativas de alunos não falantes em ambiente familiar. Esses instrumentos possibilitam a avaliação do aluno em relação à habilidade comunicativa, e permitem a coleta de informação sobre as preferências do aluno, sua capacidade de discriminação visual entre figuras, parceiros de comunicação e mobiliário.

Em relação à avaliação de preensão, Sankako, Oliveira e Manzini (2007) construíram um protocolo para avaliação de habilidades motoras de alunos com paralisia cerebral visando à adaptação de recursos pedagógicos. Esse instrumento disponibiliza fotos que permitem avaliar o tipo de preensão, os tipos de apontar e os tipos de alcance com os membros superiores.

Há na literatura estrangeira o Quality of Upper Extremity Skills Test (QUEST) que tem como objetivo avaliar a qualidade dos movimentos dos membros superiores das crianças com P.C. (DEMATTEO, at al., 1992). Neste instrumento, como parte integrante da avaliação das capacidades motoras com os membros superiores, há uma parte específica que avalia a coordenação motora fina com o uso do lápis, no entanto, o principal objetivo desta avaliação é 
direcionar as sessões de fisioterapias e terapias ocupacionais, por isso, não abarca todos os aspectos educacionais.

E o Handwriting Assesment Protocol (POLLOCK, et al. 2008), que tem o objetivo de avaliar a escrita de crianças em nível primário.

Outro instrumento que chama a atenção por avaliar o aluno dentro do contexto escolar é o School Function Assessment (SFA) que teve sua versão original construída em 1998 na língua inglesa (COSTER, et al., 1998). O SFA consiste em um teste com o formato de um questionário estruturado que permite avaliar o desempenho do aluno nas tarefas funcionais em diferentes contextos escolares do ensino fundamental. Uma das grandes contribuições deste instrumento é que, ao longo da avaliação, é possível observar que dependendo da exigência e condições do ambiente onde está o aluno, a deficiência pode ser ou não evidenciada.

Além desses, outros instrumentos de avaliação foram identificados, porém, não se encontrou nenhum com o objetivo específico de avaliar alunos com paralisia cerebral para adaptar um recurso pedagógico.

Por esse motivo, há necessidade de pesquisar na literatura possíveis itens que possam auxiliar o professor na avaliação do aluno com paralisia cerebral para adaptação de recursos pedagógicos, e para o planejamento de estratégias de ensino.

\subsubsection{Avaliações necessárias para adaptação do recurso pedagógico para o aluno com paralisia cerebral}

Dentro da sala de aula, há fatores internos e externos ao aluno que podem dificultar ou contribuir para o processo de ensino e aprendizagem. Dessa maneira, há necessidade de observar as características internas, em relação às capacidades e necessidades do aluno; e as características externas, que envolvem o ambiente em que o aluno está inserido (ARAÚJO; OMOTE, 2005).

Para Glat e Kadlec (1984), os fatores internos podem estar relacionados à capacidade física e psicológica do aluno. Os fatores externos podem estar relacionados ao ensino, ao ambiente escolar e à competência profissional do professor.

O grande desafio do professor é direcionar os fatores externos para potencializar os fatores internos, favorecendo a aprendizagem dos alunos, por exemplo, o som de uma música 
fora da sala de aula pode dificultar o aprendizado na sala, mas uma música intencionalmente colocada pode favorecer a atenção dos alunos para a aprendizagem de um determinado assunto; uma peça de um jogo que exige um grande esforço físico para a manipulação do aluno com paralisia cerebral pode dificultar o seu aprendizado, mas uma peça que facilite a preensão desse aluno e não exige grande esforço físico, pode ser estimulante para a realização da atividade.

Dessa maneira, pode-se considerar que, para a adaptação de um recurso pedagógico é necessária uma avaliação que contemple:

- $\quad$ Características individuais: possibilidades motoras, cognitivas, afetivas e de comunicação;
- $\quad$ Características acadêmicas: objetivo curricular;
- $\quad$ Características sociais: relacionamento com os pares;
- $\quad$ Características do ambiente externo: exigências do ambiente em que o aluno está inserido e acessibilidade.

Buscaram-se, então, dados na literatura que abordassem temas como: aprendizagem e planejamento de ensino, estratégias, área cognitiva, área da comunicação, área motora, área sensorial, área do contexto familiar e social que pudessem fornecer itens para a avaliação do aluno com paralisia cerebral.

\subsubsection{Aprendizagem e planejamento de ensino}

Entre as muitas funções da escola, as principais são: oferecer um ensino sobre diferentes conhecimentos, otimizar situações para a atividade, contribuir para a interação social dos alunos e para a construção da cidadania.

Em relação à aprendizagem, Glat e Kadlec (1984) dizem que há duas categorias na escola: a aprendizagem intencional e a aprendizagem não intencional.

Por um lado, a aprendizagem intencional é aquela que possui um planejamento previamente elaborado, diminuindo a possibilidade de ações momentâneas de ensaio e erro, devido ao maior controle sobre o processo de ensino.

Por outro lado, a aprendizagem não intencional é aquela que acontece sem nenhum planejamento, constituindo-se em ações momentâneas para a execução das atividades. 
Observa-se que a grande diferença entre as duas categorias de aprendizagem é em relação à presença ou ausência de planejamento. Dalmás (2005) descreveu o planejamento como sendo um processo que percorre três caminhos, o primeiro, saber o que se quer alcançar; o segundo, definir a distância que existe entre o que se tem e o que se quer alcançar e; o terceiro, programar as ações que deverão ser feitas para diminuir essa distância.

No ensino fundamental, a aprendizagem denominada intencional é a que melhor contribui para um ensino de qualidade a todos os alunos, pois é nessa aprendizagem que as atividades são melhores definidas, sendo coerente com o que se pretende ensinar e/ou avaliar (BRASIL, 2000).

Em relação ao currículo escolar, concorda-se com González (2002) ao entender que o currículo só irá oferecer um ensino de qualidade a todos, quando houver um equilíbrio entre a compreensibilidade, referente ao currículo comum e a diversidade, referente às adaptações necessárias às necessidades e habilidades dos alunos.

No Brasil, os documentos em que se baseia o currículo escolar e, consequentemente, são usados como parâmetro para avaliar o aluno em relação aos objetivos do Ensino Fundamental são os PCNs (BRASIL, 2000).

Esses documentos descrevem três competências básicas que devem ser adquiridas pelo aluno do ensino fundamental: 1) ter acesso aos bens culturais; 2) alcançar participação plena no mundo letrado e 3) desenvolver habilidades para resolver problemas da vida cotidiana. Os temas de conhecimento abordados são: temas transversais, língua portuguesa, matemática, história e geografia e ciências naturais. De uma maneira geral, o processo de ensino e aprendizagem é relacionado nesses documentos, considerando dois critérios: 1) o conhecimento anterior do aluno e 2) o conhecimento que o aluno já domina sobre o assunto pretendido.

Definir um plano de aula que contemple o conhecimento acadêmico de todos dentro da sala de aula, inclusive do aluno com deficiência e que, consiga adequar os materiais acadêmicos e as estratégias de ensino, nem sempre tem sido uma tarefa fácil para os professores do ensino regular e/ou do atendimento especializado.

Melo e Martins (2004) evidenciaram que devido à característica física limitada do aluno com paralisia cerebral, que é a sua consequência mais evidente, determinados professores podem considerá-lo como incapaz, sem oferecer oportunidades de ensino que potencializem seu aprendizado.

Em relação à percepção de professores do ensino regular sobre recursos e estratégias para o ensino de alunos com deficiência, nos exemplos de relatos trazidos no estudo de 
Reganhan e Manzini (2009), observou-se que, entre cinco professores entrevistados, quatro referiram-se à dificuldade e deficiência do aluno, sendo que, nenhum se referiu a sua potencialidade.

Os dados encontrados por Reganhan e Manzini (2009) podem influenciar na prática acadêmica do professor em relação ao planejamento de atividade e ao ensino do aluno deficiente, resultando em situações, como observadas por Nunes, Lemos e Mendes (2006), em um estudo sobre o papel do jogo no processo de inclusão de crianças com necessidades educacionais especiais no ensino regular. Nesse estudo, os autores observaram que um aluno deficiente matriculado na terceira série permanecia desenhando o tempo todo durante as aulas, sem que a atividade dele fosse planejada e/ou tivesse qualquer vínculo com o que o resto da sala estava fazendo; e, que, nesse caso, a professora raramente o chamava para participar das atividades, e não planejava nenhuma atividade para esse aluno.

Já na sala de atendimento especializado, o estudo de Mello (1999) teve como o objetivo identificar as concepções de uma comunidade escolar, do interior de São Paulo, sobre a classe especial de alunos com deficiência física. Entre as participantes estavam duas professoras que responderam uma entrevista semiestruturada sobre o assunto pesquisado. Os resultados indicaram que, o aluno com deficiência física não era concebido como incapaz devido a sua deficiência, pelo contrário, as participantes reconheciam o potencial de aprendizagem em seus alunos, desde que, observadas as suas limitações físicas, fossem oferecidos materiais pedagógicos acessíveis e estratégias para o seu ensino.

Informação contrária foi encontrada por Imamura (2008), que realizou um estudo sobre as estratégias de ensino para alunos com deficiência física em uma sala de atendimento especializado com o uso do computador. Nesse trabalho, a autora observou que a professora da classe especial para deficientes físicos descrevia seus alunos pelas limitações físicas, pelas dificuldades e por aquilo que não podiam fazer. Essa situação comprometia parte do trabalho acadêmico, pois, sem nenhum planejamento prévio, algumas situações foram observadas, como, por exemplo: 1) alunos sem realizar atividade alguma por grandes períodos de tempo; 2) alunos desenvolvendo atividade que pouco contribuía para o seu desenvolvimento acadêmico, por não estar compatível com o nível de desenvolvimento deles e 3) alunos jogando sem nenhum objetivo pedagógico, por um grande período de tempo.

González (2002) descreveu que o ensino, no qual o planejamento é baseado nas dificuldades e não nas habilidades dos alunos, é característico do currículo diferenciado, ou seja, aquele que não tem ligação com o que o resto da sala está estudando. Na opinião desse 
autor, esse currículo, na maioria das vezes, é sinônimo de um ensino improvisado, que pouco contribui para o desenvolvimento do aluno.

Martín, Jáuregui e López (2004), ao discutirem uma concepção educacional do ensino inclusivo, alertaram que a improvisação é resultado da falta de compromisso com a realização do planejamento.

A consequência dessa metodologia de ensino é a realização de atividades sem objetivo pedagógico, que podem reforçar as dificuldades acadêmicas do aluno, por não proporcionarem desafios educacionais.

Portanto, é evidenciada a importância de se avaliar a potencialidade do aluno, pois o planejamento das atividades deve partir do que ele já sabe, ou seja, do que ele já faz sozinho, acrescentando conteúdos, progressivamente, para que o aluno possa alcançar o nível seguinte de desenvolvimento (VYGOTSKY, 1991).

No contexto inclusivo, as atividades podem apresentar diferentes níveis de complexidade, para tanto, é necessário que o projeto curricular seja flexível para atender às necessidades de cada aluno (CARVALHO, 2000; GONZÁLEZ, 2002).

Curto, Morillo e Feixidó (2000) descreveram que o planejamento para qualquer tipo de ensino deve contemplar atividades significativas com finalidades pedagógicas bem definidas, concordando com os interesses dos alunos.

Em relação ao uso do recurso pedagógico adaptado como instrumento de ensino na sala de aula, o que pode determinar o sucesso ou o insucesso da atividade é o seu planejamento prévio, com objetivo e estratégias bem definidas.

Dessa forma, entende-se que as atividades devem ser planejadas para todos os alunos, contemplando conteúdos curriculares previamente planejados, com diferentes estratégias de ensino direcionadas a cada aluno, de acordo com suas necessidades individuais (FALVEY; GIVNER; KIMM, 2002).

\subsubsection{Estratégias no ensino de alunos com paralisia cerebral}

No processo de ensino e aprendizagem, a adequação da atividade é garantida quando há o planejamento prévio das estratégias de ensino baseado nas características dos alunos e do contexto em que ele está inserido (SILVA, 2009a). 
Isso pode ser observado, quando há necessidade de escolher estratégias adequadas para se evitar que um aluno, com paralisia cerebral espástica, exerça grandes esforços, evitando o aumento de tônus e desestruturação da postura adequada (ZOPPA, 2001).

O conceito de estratégia foi descrito pelo dicionário Aurélio (FERREIRA, 2004, s/n) em quatro definições: "1. Arte militar de planejar e executar movimentos e operações de tropas, navios ou aviões, visando alcançar ou manter posições relativas e potenciais bélicos favoráveis a futuras ações táticas sobre determinados objetivos; 2. Arte militar de escolher onde, quando e com que travar um combate ou uma batalha; 3. Arte de aplicar os meios disponíveis com vista à execução de objetivos específicos; 4. Arte de explorar condições favoráveis com o fim de alcançar objetivos específicos”. Na área educacional, ao enfocar o recurso pedagógico adaptado e estratégias para o ensino de alunos com deficiência física, Manzini (no prelo, p.14), definiu a estratégia como:

[...] uma ação que acontece no momento do ensino ou da avaliação do aluno. Porém, deve ser planejada anteriormente, levando em consideração as características da deficiência, as potencialidades do aluno, o objetivo que se pretende com a realização da atividade e o nível de complexidade da atividade exigida.

$\mathrm{O}$ autor relatou que as estratégias podem ser identificadas como os verbos de ações das orações no plano de ensino do professor. Um exemplo dessa identificação pode ser observado na frase: o jogo foi disponibilizado do lado esquerdo do aluno e apresentado em ordem crescente de dificuldade. Além disso, o autor afirmou que a flexibilidade é uma das principais características da estratégia. Em outras palavras, a estratégia não deve ser entendida como um procedimento semelhante ao de uma prescrição médica, na qual, cada passo deve ser fielmente seguido, pelo contrário, o planejamento da estratégia deve contemplar mais de uma ação, para uma mesma atividade, pois, caso uma estratégia não seja eficiente, outra estará disponível para atender às perspectivas de ensino e o nível de desenvolvimento do aluno.

Diante dessas definições, entende-se que, o planejamento da estratégia é uma ação que pode determinar o sucesso ou o insucesso da realização de qualquer ação, em um aspecto educacional, é a estratégia que determina a realização da atividade, devendo, portanto, ser uma prática pedagógica habitual do cotidiano de qualquer profissional que atua na área da educação.

No entanto, Reganhan e Manzini (2009), em um estudo sobre a percepção de professores do ensino regular sobre recursos e estratégias para o ensino de alunos com 
deficiência, concluíram que os professores têm dificuldades para definir o conceito de estratégia e, consequentemente, planejá-las em suas ações pedagógicas.

Para elucidar esse assunto, encontraram-se na literatura estudos sobre o uso de estratégias de ensino em ambiente escolar.

Em 2009, Silva (2009a) desenvolveu um estudo cujo objetivo foi identificar as estratégias utilizadas na intervenção de três mediadoras em atividades de reconto de histórias com quatro alunos sem oralidades, diagnosticados com paralisia cerebral. Em seu estudo, a autora identificou nove estratégias de mediação que foram utilizadas na realização das atividades: 1) Ler a história ou sentença para o aluno; 2) Apresentar cartões para reconto da história; 3) Proporcionar a identificação das personagens; 4) Questionar o aluno para favorecer sua expressão ou para compreender a sentença; 5) Favorecer a identificação das palavras dos cartões letrados e sem figura; 6) Solicitar a busca de cartões ilustrados e o aumento da sentença; 7) Indicar as linhas do livro em que os cartões das sentenças serão fixados; 8) Avaliar as ações realizadas pelo aluno; 9) Ler a sentença recontada. A autora observou que, nos casos em que as estratégias desenvolvidas pelas participantes foram previamente elaboradas, a partir da necessidade do aluno, contribuíram para o seu ensino, como, por exemplo, questionamentos e/ou dicas verbais que direcionaram o aluno à resposta correta da atividade; uso de afirmações positivas; elogios no caso de acertos; indicação da figura correta no caso de erro; utilização de frases simples ou complexas para instrução da atividade, dependendo do nível de compreensão do aluno; apresentação das atividades em sentenças únicas e simples ou complexas, respeitando a capacidade de compreensão do aluno; escolha do material de acordo com o nível cognitivo do aluno, podendo ser figuras, material em miniatura ou objetos em tamanho real. Porém, nos casos em que as estratégias escolhidas não foram planejadas e adequadas às necessidades do aluno, nem sempre contribuíram para o seu ensino. Como no caso em que a mediadora se antecipou com a conclusão da atividade, e apresentou as fichas da história na sequência correta, sem que tivesse disponibilizado um tempo adequado para que o aluno realizasse a atividade.

Em 2008, Conroy et al., em um estudo sobre as intervenções realizadas em sala de aula, pontuaram seis tipos de estratégias capazes de favorecer o comportamento dos alunos e contribuir para a aprendizagem: 1) Supervisar e monitorar continuamente a sala; 2) Construir regras para a sala em parceria com os alunos; 3) Proporcionar oportunidade para estimular a resposta dos alunos; 4) Oferecer elogios quando os alunos acertam ou quando comportam-se bem; 5) Oferecer a resposta certa ou feedback no caso de erro; 6) Implementar jogos de bom comportamento, formando pequenos grupos e líderes para ajudar o professor no 
monitoramento da classe de maneira lúdica. No entanto, os autores alertaram que as estratégias só atingem as metas esperadas se houver uma observação inicial dos alunos para que haja um planejamento que englobe as necessidades individuais de cada aluno e, ao mesmo tempo, as necessidades de toda sala.

Em 2006, Sameshima realizou um estudo sobre as habilidades expressivas de um grupo de alunos não falantes durante atividade de jogos. Nesse estudo, a autora participou como mediadora, planejando os jogos e as estratégias, as quais eram utilizadas de acordo com a necessidade de cada aluno e do grupo. Algumas das estratégias utilizadas foram: dicas verbais, instrução verbal, exposição dos recursos por um tempo previamente determinado, indagações que facilitavam a interação, intervenção para que os jogadores mais experientes esperassem a vez do jogador menos experiente e disponibilização de um tempo maior para o término do jogo. Há muitas conclusões nesse estudo que beneficiam o aluno não falante na realização de atividades. Em relação à estratégia, a autora concluiu que o planejamento prévio, tal como, a disponibilização de um tempo maior para que o aluno não falante respondesse o que foi solicitado, facilitou a interação do grupo que realizava o jogo. Essa estratégia merece atenção, pois, muitas vezes, o aluno não conclui uma atividade ou não responde adequadamente o que lhe foi perguntado, não por incapacidade, mas por falta de um tempo adequado que lhe permita fornecer a resposta. No entanto, essa estratégia só será planejada se a necessidade de disponibilizar um tempo maior for avaliada e identificada antecipadamente pelo profissional que trabalha com o aluno. Diante disso, a autora observou que o planejamento das atividades e das estratégias de ensino só foi possível porque a autora tinha conhecimento sobre: 1) os centros de interesse dos alunos, 2) o nível de participação de cada aluno, para poder oferecer oportunidades de participação a todos, independente do seu comprometimento ou timidez e 3) as necessidades de cada aluno e do grupo.

No mesmo ano, Gonçalves (2006) realizou um estudo sobre as estratégias utilizadas no ensino de crianças com paralisia cerebral incluídas no ensino infantil. Nesse estudo, determinadas estratégias foram identificadas: 1) Instruir a sala de uma maneira geral e de uma maneira mais individualizada para a aluna; 2) Deixar a aluna sem realizar atividades em alguns momentos; 3) Deixar a aluna no mesmo lugar o tempo todo, independente do fato de os outros alunos mudarem de lugar; 4) Colar fita adesiva para manter a folha fixa na mesa; 5) Elogiar em voz alta; 6) Fazer gestos de aprovação para a aluna deficiente; 7) Agrupar os alunos em grupo. A autora constatou que, em determinados casos, as estratégias contribuíram para o desenvolvimento do aluno; em outros, as estratégias e/ou a sua falta não favoreceram o seu desenvolvimento, como, no caso em que não havia: 1) a disponibilização de tempo 
suficiente para: 1.1) permitir que a aluna terminasse a atividade, 1.2) para que ela pudesse ser acomodada de forma adequada na cadeira, 1.3) para disponibilizar os materiais e a própria atividade, antes do seu início, o que dificultava a realização das atividades, resultando no seu término parcial ou no seu não término e 2) à falta de estratégia para promover a interação social do aluno, favorecendo a sua desaprovação pelo resto da turma.

Analisando os estudos citados, é possível identificar os momentos em que as estratégias podem ser consideradas como adequadas ou não adequadas, e relacioná-las com a presença ou a ausência de seu planejamento prévio.

Assim, estratégia adequada são ações realizadas que resultam em situações que favorecem o desenvolvimento do aluno, sejam elas de ensino, de interação social, de comunicação, ou outras; e estratégia inadequada são ações realizadas que resultam em situações que dificultam o desenvolvimento do aluno ou que não contribuem em nenhum aspecto para o seu desempenho, quer seja no ensino, na interação social, na comunicação ou em outras. Em relação à presença ou ausência de planejamento prévio, observa-se que, as estratégias que foram consideradas como adequadas foram, na sua grande maioria, previamente planejadas, em função das características do aluno e do ambiente de sua sala de aula. Sendo que, as poucas estratégias que foram consideradas adequadas, sem terem sido planejadas, referiram-se à interação social do aluno, não englobando aspectos educacionais.

Diante da literatura, conclui-se que, por um lado, o uso de estratégia adequada às necessidades do aluno pode favorecer não só o ensino acadêmico, mas a interação social, a comunicação e o posicionamento dos alunos. Por outro lado, o uso de estratégia inadequada pode dificultar o ensino, a interação social e o desenvolvimento dentro da sala de aula.

\subsubsection{Avaliação: Área acadêmica}

É com a avaliação inicial que o professor irá planejar sua prática pedagógica nas diferentes áreas acadêmicas de acordo com as características de seus alunos (BRASIL, 2000).

$\mathrm{Na}$ escola, a escrita é uma das habilidades mais significantes no processo de ensino e aprendizagem. Observa-se que, a escrita é a base para todo e qualquer estudo, dessa maneira, é justificável que a alfabetização seja o alvo primeiro dentre os objetivos pretendidos para os escolares. 
Entende-se, então, que uma avaliação prévia para identificar a habilidade do aluno em relação à escrita possa direcionar o planejamento de atividades relevantes ao nível de seu desenvolvimento, auxiliando a prática pedagógica do professor. Especificamente, em relação à avaliação da escrita, e incorporando a avaliação da habilidade de leitura, Capovilla e Capovilla (2000) desenvolveram um procedimento de avaliação e intervenção para desenvolver a consciência fonológica e ensinar as correspondências grafofonêmicas. Para essa intervenção foi disponibilizada uma série de trinta e nove atividades, divididas em objetivos principais: quatro atividades sobre rima, quatro atividades sobre aliteração, uma sobre a rima e a aliteração; três atividades sobre a consciência fonológica, oito atividades sobre a consciência silábica, três atividades sobre a identidade fonêmica, nove atividades sobre a consciência fonêmica e uma atividade sobre a correspondência grafema-fonema. Diante desses referenciais, observa-se que a avaliação das potencialidades do aluno no instrumento de Capovilla e Capovilla é feita levando em consideração as atividades realizadas, a participação do aluno e o desenvolvimento da sala em relação ao que se espera para uma determinada série.

No entanto, para avaliar o aluno com paralisia cerebral, além dessas considerações, é necessário avaliar também as condições externas do meio físico que impossibilitam ou viabilizam o ensino desse aluno e outras capacidades que lhe são inerentes.

Nessa perspectiva, o aluno deve ser avaliado pela sua capacidade de produzir um texto, independente do fato de ele escrever em um papel ou se devido às dificuldades motoras, ele o produza oralmente.

Entende-se, assim, que a avaliação das características cognitivas do aluno e o seu nível de desenvolvimento são indispensáveis para direcionar o planejamento futuro em cada etapa do ensino (MANZINI; DELIBERATO, 2007). Dessa maneira, é a partir da avaliação que o professor escolherá os materiais com diferentes níveis de abstração, o mais adequado ao ensino do aluno, tais como, objetos em tamanho real, objetos em miniatura, fotos, figuras coloridas e/ou figuras em branco e preto (MILLIKIN, 1996). Especificamente, para a alfabetização, é a avaliação que indicará a necessidade de adaptar o alfabeto móvel em diferentes materiais, do mesmo modo que, para o ensino da matemática, é a avaliação que indicará a necessidade de se trabalhar com materiais concretos, principalmente no início da aprendizagem (GODOI, 2001). 


\subsubsection{Avaliação: Habilidades de comunicação}

A interação humana é realizada principalmente pela comunicação oral. Essa comunicação está presente em todos os contextos da sociedade.

No entanto, os sujeitos que, por diversos fatores, não apresentam a fala oral $^{2}$ podem ter sua interação social prejudicada. Nesses casos, há dificuldades para que esses sujeitos participem de ambientes sociais que são comuns à maioria das pessoas, permanecendo em um círculo bastante restrito (SILVA, 2009b).

Especificamente no ambiente escolar, severos distúrbios de comunicação oral podem dificultar a interação entre professor e aluno, assim como a interação deste com os demais alunos, consequentemente, dificultando o processo de ensino e aprendizagem (SAMESHIMA; DELIBERATO, 2007).

Estudos indicam que o uso de recursos e estratégias adequados pode facilitar a comunicação entre interlocutores, mesmo em caso em que o aluno não possui comunicação oral (SAMESHIMA; DELIBERATO, 2007; SILVA, 2009a). No entanto, a indicação desses recursos e estratégias para a comunicação depende da avaliação individual referente às características motoras e habilidade cognitiva do aluno.

Em relação à capacidade motora, alunos com dificuldade na comunicação oral têm necessidade de usar diferentes partes do corpo para expressar mensagens comunicativas: gestos, manuseio de vocalizadores, o uso da cabeça, dos dedos, da mão, do olhar fixo, piscar os olhos, mexer as sobrancelhas, expressão facial para apontar figuras da comunicação alternativa (GLENNEN, 1996) e, por isso, a avaliação dessas potencialidades é determinante para a escolha de instrumentos de comunicação e/ou recursos pedagógicos que poderão ser utilizados (MANZINI; DELIBERATO, 2004).

Em outras palavras, não só as vocalizações devem ser alvo da avaliação, mas qualquer tipo de linguagem, incluindo as expressões faciais, os gestos e os movimentos corporais, pois, a falta de conhecimento do professor sobre as habilidades e necessidades de comunicação dos alunos pode dificultar a ação de adaptar materiais pedagógicos (DE PAULA, 2007).

Como uma das, primeiras características a ser avaliada, Manzini (2000c) destacou a identificação dos mecanismos que a criança utiliza para expressar preferências, desejos ou

\footnotetext{
${ }^{2}$ Entende-se por alunos que não apresentam fala oral, aqueles que não conseguem se comunicar pela fala, ou seja, não conseguem oralizar.
} 
recusa com o uso dos conceitos "sim" ou "não", pois, em caso de dificuldades motoras em que o aluno não consigue realizar movimentos com a cabeça, outras partes do corpo devem ser utilizadas.

Deliberato (2007), em um estudo sobre a acessibilidade comunicativa no contexto acadêmico, evidenciou a importância de uma avaliação prévia para identificar as possibilidades comunicativas do aluno. Essa avaliação, segundo a autora, é indispensável para planejar uma intervenção adequada com recursos de comunicação a partir do vocabulário funcional do aluno em diferentes ambientes, na interação com diversos interlocutores.

Conclui-se, dessa maneira, que além da escolha adequada do recurso para comunicação, é necessário desenvolver estratégias que facilitem a interação do aluno com diferentes parceiros de comunicação, e, consequentemente, proporcionar situações significativas para que o aluno desenvolva a habilidade comunicativa (BERSH; MACHADO, 2007).

\subsubsection{Avaliação: membro superior}

É indiscutível a importância dos movimentos realizados com os membros superiores na vida dos seres humanos para a realização de atividades.

Todas as atividades que são comuns à vida diária do ser humano são realizadas com a presença direta ou indireta da função manual, como, por exemplo, segurar um pente para pentear o cabelo, segurar o talher para se alimentar ou mesmo segurar o próprio alimento, vestir-se, escrever com o lápis ou digitar um texto, entre outras infinitas atividades (SILVA; BRACIALLI; MANZINI, 2009).

Para a obtenção de novos conhecimentos, a função dos membros superiores é indispensável para gerar estímulos e para que haja a exploração do ambiente externo (PAIVA, 2007).

Nesse contexto, a mão é responsável pela preensão de objetos com diferentes formas e tamanhos, além de captar e interpretar estímulos referentes à dor e temperatura dos objetos manipulados. No entanto, determinadas situações patológicas, como no caso da paralisia cerebral, podem apresentar comprometimentos motores dos membros superiores, relacionados à alteração de tônus, a deformidades, aos déficits sensoriais, e resultar em impacto na realização das atividades que requerem o uso da função manual (SAURON, 2001). 
Esses comprometimentos determinam as possibilidades de preensão referentes ao quadro motor e tátil de cada aluno. Por esse motivo, avaliar essas habilidades das extremidades superiores torna-se fundamental para que o recurso seja adaptado de acordo com as suas possibilidades, permitindo o seu manuseio funcional (CRUZ, 2006; SANKAKO; OLIVEIRA; MANZINI, 2007).

Outro aspecto muito comum nos alunos com paralisia cerebral e que é avaliado no instrumento de preensão de Sankako, Oliveira e Manzini (2007), é a utilização excessiva da mão não comprometida ou a não utilização da mão com maior limitação motora.

Essa situação é bastante comum nos alunos com paralisia cerebral. Eles, frequentemente, utilizam o membro com melhor desempenho para manipular os materiais e evitam utilizar o membro mais comprometido, mesmo tendo condições físicas para fazer o movimento.

Entre as várias razões para justificar o uso do lado sem comprometimento ou menos comprometido, está na facilidade em utilizar esse membro em relação ao outro, e/ou a tentativa de ocultar o membro com maior comprometimento motor.

A utilização do membro mais comprometido deve ser incentivada pelo professor, pois a falta de funcionalidade pode agravar ainda mais as deformidades motoras, as dores musculares e, consequentemente, acentuar a limitação funcional.

É função do professor avaliar a possibilidade dos dois membros superiores em realizar as atividades e/ou manipular recursos pedagógicos, para que, quando necessário, sejam planejadas estratégias que favoreçam o movimento desses membros, principalmente do mais comprometido, de acordo com as capacidades de cada aluno.

\subsubsection{Avaliação sensorial}

Para adaptar o recurso pedagógico e planejar as metas de ensino é necessário avaliar as possibilidades sensoriais, para utilizá-las em favor do desenvolvimento do aluno. Por isso, torna-se indispensável fazer uma avaliação para identificar se há ou não alguma alteração sensorial antes de adaptar um recurso pedagógico (MANZINI; DELIBERATO, 2007), identificando inclusive se tem origem orgânica, ou se é determinada pela falta de experiência com o ambiente externo (GUSMAN; TORRE, 2001), devido à privação de exploração motora, como consequência das limitações físicas. 
A visão é um canal sensorial que deve ser estimulado na criança através de experiências e interação com o meio ambiente, para que, na fase adulta, possa proporcionar associações mutissensoriais, tais como, identificar o tipo de textura, o tamanho de um objeto, sem ter que tocá-lo, apenas pela visão (CHAIKIN, 2004). No caso da criança com paralisia cerebral, é importante observar se essa criança apresenta ou não alteração visual, visto que, o número de crianças com paralisia cerebral que apresenta alterações visuais é maior do que o número de crianças sem deficiência (TALUSE, 2001). Gallaue e Ozmun (2005) afirmaram que a capacidade visual engloba determinadas habilidades: 1) a percepção em nível plano, que foi definida como sendo a habilidade de localizar um objeto específico dentro de um cenário; 2) a percepção de profundidade, que permite a visão tridimensional de objetos; 3) coordenação visual-motora é a habilidade de observar e acompanhar um objeto em movimento, de tal maneira que possa ser feita uma interceptação na sua trajetória. Observa-se que, as habilidades visuais descritas por Gallaue e Ozmun (2005) quando limitadas, interferem diretamente na realização de atividades. Dessa maneira, a avaliação dessas habilidades é importante para adaptar o recurso pedagógico e planejar estratégias de ensino. Porém, a limitação visual pode não estar, especificamente, apenas no aluno, pois a localização da sua carteira na sala pode favorecer ou impossibilitar a visualização das atividades na lousa, principalmente, no caso do aluno com paralisia cerebral, quando mal posicionado em relação à lousa, tentando visualizá-la, pode liberar espasmos tônicos extensores. Em relação à atividade, o seu posicionamento na carteira respeitando o campo visual do aluno contribui para que haja concentração na realização da atividade (PEREIRA, 2001), além disso, devem ser observadas as possibilidades visuais do aluno antes de planejar a atividade, para que, quando necessário haja uma adaptação no tamanho da fonte e na escolha entre a cor da letra em relação ao fundo, contribuindo para visualização do aluno.

Em relação ao tato, o que pode influenciar na preensão de objetos pelo aluno com paralisia cerebral é a possível alteração na sensibilidade térmica, tátil e/ou na função discriminativa. A sensibilidade térmica é a que permite que o indivíduo identifique as diferentes temperaturas que tocam a pele, identificando o quente ou o frio; a sensibilidade tátil é a que permite que o indivíduo perceba quando algo encostou sobre a sua pele (DORETTO, 2005), o tato discriminativo é responsável por reconhecer o tamanho, forma, textura e movimentação de objetos na pele (CARDOSO; SINISCALCHI, 2010). Em qualquer tipo de alteração relacionada ao tato, há influencia na preensão, manipulação e, consequentemente, na realização das atividades com qualquer tipo de objeto. Em relação à habilidade motora, há estudos na literatura que permitem relacionar o tipo de paralisia cerebral à determinada 
característica sobre a preensão motora de membros superiores. Em 2004, Mélo realizou uma avaliação para identificar a sensibilidade nas mãos de oito crianças com paralisia cerebral diplégica (6 espástico, 1 atetóide e 1 coreoatetose) comparadas com 8 crianças sem deficiência, em idade escolar. Nesse estudo, entre os resultados encontrados, destaca-se que há uma diminuição da sensibilidade tátil nas mãos das crianças com paralisia cerebral quando comparadas com crianças sem deficiência, da mesma idade.

Em 2007, Paiva analisou a influência da textura do recurso pedagógico em atividade de encaixe realizada por seis alunos com paralisia cerebral espástica. Para esse estudo, a autora utilizou um instrumento chamado de transdutor de força capaz de medir a força de preensão palmar exercida pelo aluno durante a atividade. Esse transdutor foi revestido com três tipos de texturas, a lisa: papel verniz, a intermediária: papel camurça e a áspera: lixa, com as quais os alunos realizaram atividades de encaixe. A autora concluiu que houve diferenças entre a preensão de um mesmo objeto com texturas diferentes: para realizar a atividade com a textura áspera houve necessidade de uma menor força palmar em comparação com as outras texturas; e que, com a manipulação do objeto revestido com a textura lisa, o tempo de realização da tarefa foi menor, assim como, teve o melhor desempenho na trajetória do movimento. O trabalho evidenciou que as texturas dos recursos pedagógicos podem influenciar no desempenho da realização da atividade em alunos com paralisia cerebral espástica.

No mesmo ano, Oliveira (2007) avaliou a sensibilidade e a função motora de membros superiores em crianças com paralisia cerebral do tipo diplegia espástica. Nesse estudo, foram avaliadas trinta crianças com diagnóstico de paralisia cerebral e trinta crianças sem deficiência. Entre os resultados encontrados, destaca-se o déficit de sensibilidade encontrado nas crianças com paralisia cerebral, mesmo em crianças com comprometimento motor predominantemente em membros inferiores, quando comparadas com crianças sem deficiência da mesma idade. Dessa maneira o autor reforça a necessidade de avaliação criteriosa de todos os membros, mesmo naqueles que, aparentemente, não possuem comprometimento evidente.

Em relação ao olfato, entende-se que, apesar de pouco estudado como instrumento da prática pedagógica, pode trazer benefícios para o desenvolvimento do aluno, principalmente, no caso daqueles que apresentam alterações em outros canais sensoriais. Dessa maneira, atribui-se ao olfato o papel de detectar a presença de diferentes odores que, por sua vez, podem desencadear recordações e sensações de diversas naturezas, como, por exemplo, calmante, relaxante, agradável, irritante e enjoativa (WOSNY, et al., 2008). 
Em relação à audição, é função do professor e de todos os profissionais atuando na escola, observar a possível perda auditiva que os alunos possam apresentar. Lamônica, Chiari e Pereira (2002) desenvolveram um estudo com o objetivo de estudar a provável ocorrência de perda auditiva em indivíduos com paralisia cerebral sem queixa de problemas de audição. Nesse estudo, entre 67 indivíduos com paralisia cerebral, entre 7 e 16 anos, 51\% apresentaram perda auditiva, desde o grau leve ao grau severo, sem que tivesse sido diagnosticado antes do estudo. Os autores consideraram que esse diagnóstico tardio pode ser devido a determinados fatores: 1) a perda auditiva ser mascarada pelas alterações motoras do indivíduo, ou seja, a ausência de resposta aos estímulos auditivos é atribuída pela dificuldade em realizar movimentos motores e, 2) devido à conduta dos familiares de antecipar e interpretar as ações do indivíduo.

Para os autores Cardoso e Siniscalchi (2010) qualquer alteração sensorial pode afetar a área motora, social, emocional e cognitiva do indivíduo. $\mathrm{Na}$ escola, a avaliação sensorial antes de adaptar um recurso pedagógico pode favorecer a realização da atividade, pois, identificando as alterações sensoriais, o profissional da área da educação especial pode adaptar um recurso que possua características físicas para reforçar as capacidades do aluno e, ao mesmo tempo, evitarem reações adversas com o contato de determinado material, impossibilitando a sua manipulação.

Desse modo, é necessário investigar as possibilidades sensoriais do aluno, para proporcionar, quando necessário, situações de experiências, conhecimento e exploração do ambiente externo.

\subsubsection{Avaliação: posicionamento}

Avaliar a capacidade motora é indispensável para indicar o recurso pedagógico que irá possibilitar o manuseio do aluno e a realização da atividade. Em relação ao posicionamento, é sabido que o favorecimento da realização de qualquer atividade e a prevenção de posturas viciosas dependem diretamente de um posicionamento adequado (SANTOS, 1998).

Em situação de trabalho, um indivíduo sentado causa maior impacto na coluna vertebral do que um indivíduo na posição em pé (MORO, 2000). 
No ensino fundamental, o aluno permanece sentado na sua cadeira realizando atividades a maior parte das horas em que está na escola, por isso, conclui-se que o posicionamento é um dos fatores importantes a ser observado durante o período escolar.

Os autores Braccialli, Manzini e Vilarta (2005) e Alpino (2008) alertaram em seus estudos que a permanência na postura sentada, por um grande período de tempo, piora a postura dos alunos com paralisia cerebral espástica e que, portanto, há necessidade de se oferecer oportunidades para que esses alunos modifiquem sua postura.

Em 2000, Moro desenvolveu um estudo comparativo da postura sentada do sujeito em três diferentes situações de mobiliário. O estudo contou com 37 estudantes com idade variando entre 18 e 26 anos que realizaram uma atividade de leitura por aproximadamente 45 segundos, em três tipos de mobiliário, denominados por mobiliários A, B e C. Os mobiliários denominados por A eram formados por cadeira com assento apresentando inclinação de $30^{\circ}$, com apoio de joelhos e mesa inclinada em $15^{\circ}$. Os mobiliários denominados por $\mathrm{B}$ eram formados por cadeira com assento apresentando inclinação de $30^{\circ}$, com apoio de joelhos e mesa na horizontal. Os mobiliários denominados por $\mathrm{C}$ eram semelhantes aos modelos encontrados na escola, formados por cadeira com assento, mesa na posição horizontal, sem apoio para joelhos e com suporte para costas. Com os dados obtidos, o autor fez apontamentos sobre a comparação entre o uso dos mobiliários $\mathrm{A}, \mathrm{B}$ e $\mathrm{C}$ e chegou a determinadas conclusões: A e B permitiram que o tronco se mantivesse mais alinhado com o quadril, diminuindo as sobrecargas posturais ocorridas em maior número na posição $C$; e que os mobiliários A e B favoreceram a postura do braço em relação à linha do tronco e diminuíram a força na coluna vertebral. Entre o mobiliário $\mathrm{A}$ e $\mathrm{B}$, a mesa que melhor contribuiu para o posicionamento da atividade em relação à postura do pescoço foi o mobiliário A, já que este possuía uma mesa inclinada que diminuía a inclinação do pescoço para fazer a atividade. Diante dos resultados, o autor concluiu que o posicionamento em situação experimental que melhor contribuiu para uma postura mecanicamente correta foram os mobiliários da situação $\mathrm{A}$, diferentes dos mobiliários encontrados nas escolas, que, geralmente, se assemelham aos da situação C.

Em outro estudo, Silva e Santos (2007) verificaram se os mobiliários escolares usados nas salas das séries iniciais do ensino fundamental de uma cidade do Rio Grande do Sul eram (in) adequados aos seus usuários. Para esses autores, o estudo se justificou pelo fato de que a saúde física, psicológica e, consequentemente, a atenção e o interesse para a aprendizagem dependem diretamente do uso de mobiliários escolares que contribuam para uma postura sentada adequada. Já no início da pesquisa, eles observaram uma situação 
bastante comum nas escolas regulares, os mobiliários eram utilizados por alunos de diferentes faixas etárias. Assim, foi constatado que uma mesma mobília era utilizada por crianças das séries iniciais, por jovens das séries finais do ensino fundamental e por adultos da educação de jovens e adultos. Como resultado, os autores concluíram que o mobiliário encontrado na escola favorecia à manutenção da postura inadequada, desconfortos, vícios e desvios de postura, que, consequentemente, afetam a atenção do aluno e o seu aprendizado.

Com base nesses estudos, fica evidente que nem sempre o mobiliário encontrado na escola proporciona um posicionamento adequado dos alunos.

No caso dos alunos com paralisia cerebral, a falta de um mobiliário adequado traz consequências ainda mais severas, pois a postura inadequada pode limitar movimentos motores necessários à realização das atividades, e contribuir para uma piora no quadro de limitações motoras apresentadas, contribuindo para acentuar a dor crônica nesses alunos.

Segundo Mirabelli-Susens (2004), a presença da dor crônica em uma pessoa pode diminuir a sua capacidade de realizar atividades, se relacionar com outras pessoas, participar de atividades sociais, diminuindo a qualidade de vida.

Sabe-se, no entanto, que devido à falta de conhecimento sobre como posicionar adequadamente o aluno com paralisia cerebral, e a falta de mobiliário com adaptações necessárias a cada aluno presente na escola, nem sempre esses alunos mantêm uma postura adequada. E que, portanto, acentua-se uma das maiores dificuldades dos alunos com paralisia cerebral, que é manter um equilíbrio postural para a realização das atividades no ambiente escolar (BRACCIALLI et al., 2008).

Um posicionamento adequado permite aos alunos com paralisia cerebral maior estabilidade, favorecendo o controle motor funcional mais fino, devido à redução da influência de movimentos anormais e a diminuição das deformidades (MARUJO, 2001), contribuindo para o ensino.

Para que uma postura sentada funcional seja mantida, Radell (1996) descreveu que há cinco itens que precisam ser observados para facilitar a função de braço e mão: 1) a estabilidade postural; 2) a mobilidade; 3) o posicionamento adequado da cabeça; 4) do tronco e 5) dos pés.

Dessa maneira, para que alunos com grandes limitações motoras consigam um posicionamento adequado é necessário um mobiliário adaptado de acordo com suas necessidades (BRACCIALLI et al., 2008).

Algumas das adaptações que podem ser feitas no mobiliário a fim de contribuir para um posicionamento adequado dos alunos com dificuldades motoras estão relacionadas ao 
assento, ao uso da faixa no tórax, uso do abdutor, apoios para os pés, entre outras, que deverão ser escolhidas de acordo com a necessidade de cada aluno (BRACCIALLI; MANZINI; REGANHAN, 2004; BRACCIALLI; MANZINI; VILARTA, 2005).

A disponibilização de um assento adaptado às necessidades individuais do aluno pode favorecer a adequação postural, o controle motor voluntário e reduzir as deformidades (ALPINO, 2008). Os mesmos benefícios podem ser conquistados quando o apoio para os pés é regulado adequadamente (MARTÍN; JÁUREGUI; LÓPES, 2004).

No entanto, o estudo de Braccialli, Manzini e Aires (2003) que investigou os tipos de mobiliários utilizados nas salas especiais para deficiente físico em cidades do Estado de São Paulo, constatou, com a análise de questionários respondidos por dezenove professores de salas especiais, que, quatorze relataram que os mobiliários existentes na sala não eram adaptados para os alunos individualmente, e, que, quando possível, apresentavam alguns ajustes. Observa-se que, mesmo em salas com atendimento prioritário ao aluno com deficiência física, há a necessidade da oferta de mobiliários adaptados às necessidades específicas de cada aluno.

Além da cadeira, as características da mesa podem dificultar ou favorecer o ensino dos alunos com limitações motoras, como no caso dos alunos com paralisia cerebral. Algumas dessas características estão relacionadas à altura da mesa, a sua possível inclinação na parte superior, ao tamanho da tampa e ao modelo escolhido.

Sobre esse assunto, Braccialli, Manzini e Vilarta (2005) estudaram a influência do mobiliário adaptado na variação angular da curvatura lombar em dez indivíduos com paralisia cerebral espástica que mantinham a posição sentada sem auxílio. Nesse estudo, os autores revelaram que a mesa com recorte semicírculo à altura do tórax "[...] proporcionou o endireitamento do tronco, pois, restabeleceu a curvatura fisiológica da região lombar, consequentemente a retroversão pélvica diminuiu e a cabeça alinhou-se com o corpo" (BRACCIALLI; MANZINI; VILARTA, 2005, p. 94).

Diante da literatura, observa-se que é necessário que haja um posicionamento adequado a todos os alunos, em especial aos alunos com paralisia cerebral.

Sabe-se, porém, que mesmo não fazendo parte das responsabilidades do professor disponibilizar mobiliários adequados, é a partir da sua avaliação que a necessidade destes é indicada aos profissionais responsáveis para a aquisição desse tipo de mobiliário. 


\subsubsection{Avaliação: contexto social}

A permanência e o sucesso acadêmico do aluno matriculado no ensino regular dependem das relações sociais que se estabelecem entre esse aluno e a sociedade escolar (BARBOSA; AZEVEDO; CASELATTO, 2007). Nos casos dos alunos com deficiência, as situações em que o aluno é matriculado em classe comum, mas continua realizando atividades solitariamente, não devem ser entendidas como inclusão (OMOTE, 2004).

Em relação aos alunos com paralisia cerebral, o favorecimento da interação do aluno dentro da sala de aula depende, na maioria dos casos, de medidas tomadas pelo professor com o objetivo específico de favorecer o desempenho acadêmico do aluno em interação com o resto da sala (ALPINO, 2008), como, por exemplo, no caso dos alunos que usam a comunicação alternativa, na qual é indispensável que os símbolos sejam conhecidos por todos, para que haja possibilidade de interação entre os alunos (MILLIKIN, 1996).

Assim, a interação social do aluno com os outros sujeitos da educação deve ser uma das metas a ser alcançada para garantir que todos participem das oportunidades educacionais oferecidas pela escola (BRASIL, 2000).

Segundo Antunes (2001), a sociabilidade e a rede de relações sociais são elementos insubstituíveis na formação humana, e é papel do professor investigar e proporcionar ensinamentos referentes a ações que contribuam para um bom relacionamento social entre os alunos.

Nessa perspectiva, um dos aspectos colaborativos para garantir a qualidade educacional é estimular um clima social favorável, que envolva o maior número possível de sujeitos (DÁLMAS, 2005).

Acredita-se então, que o professor seja o responsável por oferecer oportunidades de interação social entre alunos, principalmente, em caso em que haja essa dificuldade. A exemplo dessa ação, Conroy et al. (2008) descreveram que é no início do ano que o professor e seus alunos devem planejar as regras da sala, contemplando regras de comportamento para favorecer a aprendizagem de todos, que deverão ser cumpridas ao longo do ano letivo.

Sobre esse assunto, Ravazzi e Gomes (2009) desenvolveram um estudo sobre a interação do aluno com paralisia cerebral nas aulas de educação física. Entre os resultados desse estudo, os autores observaram que entre quinze alunos sem deficiência, da sala que possuía alunos com deficiência, quando questionados se havia alguma aluno deficiente ou diferente em sua turma, onze responderam que sim, e quatro responderam que não. Os autores 
observaram que, o que contribuiu para que o aluno com paralisia cerebral fosse aceito ou não no convívio social foi a postura dos professores em relação à presença do aluno em sua turma.

Omote (2005) descreveu determinados aspectos que podem influenciar nas atitudes sociais em relação à inclusão, como, por exemplo: 1) presença ou ausência de uma formação especializada para receber os alunos com deficiência em sua sala; 2) a compreensão do professor sobre a importância das atitudes sociais para a permanência do aluno com deficiência em sua sala; 3) o grau de comprometimento do aluno; 4) as características do contexto social; 5) conteúdo das informações previamente recebidas do aluno antes de sua chegada e, 6) experiências anteriores.

Observa-se que, a interação social pode se tornar favorável ou desfavorável à presença do aluno com deficiência no ensino regular, dessa maneira, acredita-se que, o professor especializado e outros profissionais atuantes na escola devem planejar e executar contextos significativos, para possibilitar atitudes sociais favoráveis (BRASIL, 2000), seja entre alunos, funcionários e/ou professores. No entanto, essas ações apenas serão desenvolvidas se forem identificadas como necessárias.

\subsection{Avaliação: uso do computador}

O computador como um instrumento auxiliar ao ensino dentro da sala de aula tem se tornado uma ferramenta indispensável, porém, só é entendido como sendo pedagógico, quando o seu uso se justifica por um planejamento educacional específico, contemplando estratégias de ensino que o viabilize para o desenvolvimento de atividades acadêmicas (IMAMURA, 2008).

No caso de alunos com limitações motoras que impedem ou dificultam o manuseio de lápis, o uso do computador pode garantir o acesso a escrita, a produção de texto e, no caso dos alunos com dificuldade ou ausência da fala oral, esse instrumento pode auxiliar na comunicação funcional (BERSCH, 2006).

Imamura (2008) complementou que o uso do computador por alunos com deficiência, além de favorecer o acesso ao currículo e à comunicação, pode também favorecer a interação desses indivíduos com seus pares e servir como fonte de informações atualizadas sobre assuntos de seus interesses. 
No entanto, as dimensões físicas do computador nem sempre favorecem a manipulação do aluno com paralisia cerebral. A utilização das teclas ou do mouse convencional, por um aluno com dificuldades motoras nos membros superiores, pode ser uma tarefa difícil ou até mesmo impossível de ser realizada.

Nesse contexto, uma avaliação sobre as potencialidades motoras do aluno pode favorecer a adaptação de acionadores de diferentes tamanhos, modelos e finalidades, para alunos com maiores comprometimentos motores que não conseguem acessar o teclado tradicional (GLENNEM, 1996).

Glennem (1996) observou que para cada caso haverá uma adaptação específica, como, por exemplo, em relação à regulação da pressão para acionar o teclado para alunos com alto tônus muscular, evitando o acionamento repetido de uma mesma tecla, assim como, o uso de acionadores com ativação mais leve para alunos com hipotonia.

Concordando com essas contribuições, Sampaio e Reis (2004) descreveram que é necessário fazer uma avaliação das características do sujeito com paralisia cerebral e os recursos disponíveis para direcionar as adaptações no computador. Sobre a avaliação do aluno, os autores destacaram as seguintes características: motora, cognitiva e socioemocional; e sobre a avaliação dos recursos disponíveis: possibilidades e dificuldades de acesso ao computador e escolha dos recursos adaptados que poderão facilitar a sua manipulação. Em relação às adaptações, os autores destacaram que há três possibilidades de modificação para tornar o computador acessível às necessidades do usuário: 1) recursos de acessibilidade do próprio computador (Windows), nos quais pode ser modificado o tamanho da fonte, a velocidade do cursor, o acionamento da tecla, entre outros, sugeridos para indivíduos que necessitam de modificações, mas não de adaptações, devido ao pouco nível de dificuldade; 2) adaptações intermediárias, que são materiais adaptados ao usuário e não à máquina, como, por exemplo, órteses, pulseira de peso, entre outras; 3 ) adaptações no próprio computador, como, por exemplo, mouses especiais, acionadores eletrônicos, programas especiais, entre outras.

Lourenço (2008) traduziu, adaptou e sistematizou um instrumento de avaliação do uso do computador por alunos com paralisia cerebral. Esse estudo justificou-se pela necessidade de oferecer acesso ao uso do computador, contemplando as necessidades físicas dos alunos, suas potencialidades e a exigência da tarefa que deveriam ser desempenhadas. $\mathrm{O}$ instrumento ainda não está na sua versão final para uso, mas encontra-se na versão-teste, que pode ser objeto de estudos para comprovar sua eficácia quanto à avaliação de alunos com paralisia cerebral. 
Conclui-se, dessa maneira, que há possibilidade de adaptação para facilitar o uso do computador para alunos com dificuldades motoras, contribuindo para o seu acesso e, consequentemente, o sucesso de suas atividades, no entanto, é preciso fazer uma avaliação precisa sobre as características do aluno e dos recursos disponíveis, e utilizar os instrumentos disponíveis para cumprir tal tarefa.

\subsubsection{Importância da avaliação para a adaptação do recurso pedagógico}

Observa-se, que, antes de adaptar um recurso pedagógico para ser utilizado em qualquer dimensão de conhecimento é necessário avaliar as características motoras, cognitivas, comunicativas, sociais do aluno, e do ambiente escolar em que ele está inserido.

Essa avaliação justifica-se pela necessidade de se observar o aluno como um todo e não considerando suas partes individuais. Entende-se que, muitas vezes, sem um instrumento que auxilie o professor na indicação dessas áreas, a avaliação pode focalizar uma característica que esteja mais evidente e deixar outras que são indispensáveis para o seu ensino. Para exemplificar essa situação, pode-se pensar em uma avaliação na qual, o professor avalia o aluno com paralisia cerebral e verificar que ele não lê. Diante dessa avaliação o professor oferece atividades e adapta recursos para desenvolver essa habilidade de acordo com suas necessidades, no entanto, o professor não avalia (anteriormente a adaptação) que há grandes dificuldades para o aluno interagir com o resto da sala, e que, essa situação influencia na realização da atividade de leitura, visto que, na maioria das vezes, para se avaliar a capacidade de leitura do aluno é preciso que ele leia em voz alta ou que utilize algum recurso de comunicação alternativa para o professor, diante da sala de aula. Na situação anterior, o professor identificou uma necessidade do aluno e ofereceu condições para o seu desenvolvimento, no entanto, a avaliação parcial não identificou outra necessidade que não estava tão evidente, mas que antecedia a primeira.

A seguir, na Figura 1, um esquema é apresentado demonstrando que quando a avaliação considera um maior número de variáveis fornece dados para direcionar a adaptação do recurso e o planejamento de estratégias para participação do aluno com paralisia cerebral no contexto da sala de aula comum. Consequentemente, acredita-se que essa avaliação possa contribuir para uma aprendizagem planejada, direcionada e aumentar as condições para proporcionar elementos favoráveis ao ensino do aluno com paralisia cerebral. 


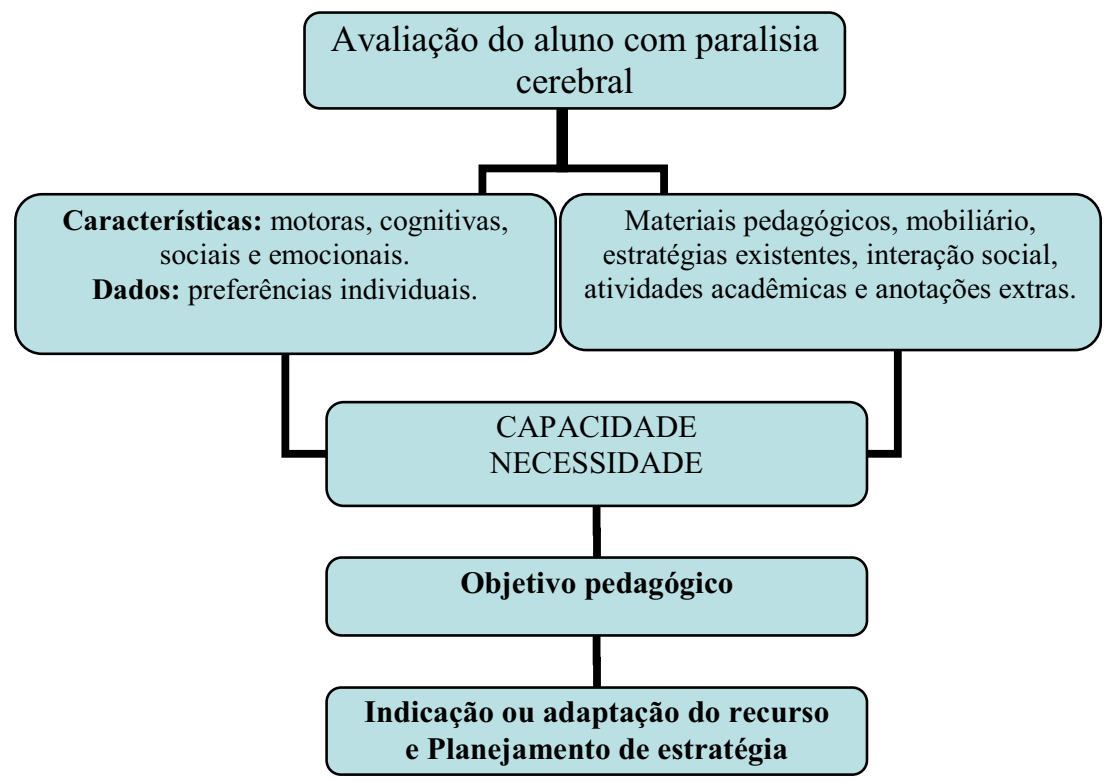

Figura 1- Esquema da avaliação do aluno com paralisia cerebral

Assim, diante da falta de um instrumento que direcione essa avaliação e reúna de modo sistematizado toda a informação, o objetivo desse estudo é proposto. 


\section{OBJETIVO}

Elaborar um instrumento de avaliação para prescrição e adaptação de recursos pedagógicos para o ensino do aluno com paralisia cerebral e planejamento de estratégias. 


\section{DESENVOLVIMENTO DAS QUATRO VERSÕES DO INSTRUMENTO DE AVALIAÇÃo}

O instrumento de avaliação foi construído em quatro versões ${ }^{3}$, e a metodologia para a elaboração dos instrumentos foi inicialmente baseada nas orientações descritas por Audi (2004), que desenvolveu um protocolo de avaliação de acessibilidade física em escolas do Ensino Fundamental. No entanto, ao longo do desenvolvimento da atual pesquisa, houve adequações metodológicas específicas para atender a problemática e o objetivo do estudo.

No trabalho de Audi (2004) o instrumento de avaliação foi construído em três versões, das quais, a primeira versão, após ter sido construída a partir de referências bibliográficas específicas, foi avaliada por um grupo de arquitetos, que analisaram o instrumento e direcionaram a construção da segunda versão. Esta versão, por sua vez, foi utilizada na avaliação de escolas de um determinado município, por um grupo de participantes da área da educação e pela própria pesquisadora. Nessa etapa do estudo, as informações sobre a utilização do instrumento nortearam a construção da sua terceira versão.

\subsection{Participantes}

Participaram da pesquisa onze estudantes do quarto ano de pedagogia da Habilitação em Educação Especial, área de deficiência física, da Faculdade de Filosofia e Ciências, UNESP, Marília, e quatro profissionais da área de educação especial (três docentes do Programa de Pós-graduação em Educação e do departamento de Educação Especial, e o outro, formado em pedagogia com Habilitação em Deficiência Física e aluna do programa de Pósgraduação em Educação, na linha de Educação Especial no Brasil).

\subsection{Contexto do desenvolvimento das três versões do instrumento de avaliação}

\footnotetext{
${ }^{3}$ O projeto de pesquisa foi submetido à avaliação do Comitê de Ética da Faculdade de Filosofia e Ciências da UNESP - Campus de Marília, sendo aprovado pelo Parecer no . 2210/2008 na data de 27/08/2008. Os participantes do estudo assinaram o termo de consentimento livre e esclarecido.
} 
As participantes deste estudo eram alunas das turmas do período diurno e do período noturno da Habilitação em Educação Especial, na Área de Deficiência Física. Algumas cursavam o quarto ano do curso de graduação em Pedagogia, da Faculdade de Filosofia e Ciências de Marília; e outras, já eram formadas e estavam complementando seus estudos.

$\mathrm{Na}$ ocasião do desenvolvimento da pesquisa, além do estágio curricular, as participantes concluíam a disciplina Métodos, Técnicas e Recursos para o Ensino do Aluno Deficiente Físico, na qual, um dos principais objetivos era avaliar as características físicas, motoras e cognitivas do aluno com deficiência física para projetar um recurso pedagógico adaptado, e aplicá-lo.

Até aquele momento, as participantes eram orientadas a avaliar o aluno do estágio seguindo determinados critérios que eram aprendidos na disciplina, já que, anteriormente a esta pesquisa, não havia um instrumento que pudesse guiar a avaliação, visando prescrever e/ou adaptar um recurso pedagógico.

Aproveitando essa situação específica, as participantes foram convidadas a participar da pesquisa, utilizando o instrumento de avaliação para avaliar seu aluno do estágio. Dessa maneira, as participantes que não optassem participar da pesquisa não teriam nenhum prejuízo curricular ou acadêmico, pois poderiam fazer a avaliação do aluno como elas já haviam sido orientadas (sem o uso do instrumento).

É preciso salientar, ainda, que o estágio da Habilitação era na área da deficiência física, por isso, nem todos os alunos do estágio tinham o diagnóstico de paralisia cerebral.

Assim, havia alunos com paralisia cerebral matriculados no ensino fundamental, alunos com paralisia cerebral não matriculados no Ensino Fundamental, e alunos não diagnosticados com paralisia cerebral. A decisão de manter todas as participantes (que avaliaram alunos não diagnosticados com paralisia cerebral e aqueles diagnosticados, mas que não estavam matriculados no Ensino Fundamental), justificou-se por entender que naquele momento da pesquisa, o que se pretendia era verificar se os itens avaliativos do instrumento eram entendidos pelas participantes. Dessa forma, o foco da pesquisa, naquele momento, era a interpretação do instrumento e não o resultado da avaliação do aluno, podendo, portanto, permanecer no estudo as participantes que possuíam alunos com deficiência física sem o diagnóstico de paralisia cerebral. Nessas condições, as participantes poderiam optar por usar os dados coletados para adaptar o recurso, caso o instrumento as auxiliasse nessa avaliação; ou caso o instrumento não as auxiliasse, as alunas poderiam colaborar com o estudo, descrevendo os motivos pelos quais o instrumento não foi funcional para a avaliação daquele determinado aluno. 


\section{CONSTRUÇÃO DA PRIMEIRA VERSÃO DO INSTRUMENTO DE AVALIAÇÃO}

Para a construção da primeira versão do instrumento de avaliação foram considerados: 1) a análise de recursos pedagógicos já adaptados; 2) materiais publicados sobre recursos pedagógicos adaptados; 3) instrumentos de avaliação com enfoque educacional; 4) referências literárias para a elaboração dos itens avaliativos e estruturação do instrumento. O processo de construção da primeira versão do instrumento demorou sete meses (de abril a outubro de 2008).

Inicialmente, foram analisados os recursos pedagógicos existentes no Laboratório de Educação Especial Prof. Ernani Vidon (por volta de 100 recursos, tais como, caderno imantado, réguas adaptadas, caderno de madeira, jogo de memória, jogo da multiplicação, livro de leitura ampliado, virador de páginas, etc.). Essa analise teve o objetivo de identificar o tipo de material que foi utilizado para a adaptação desses recursos, identificando inclusive as suas dimensões (peso, tamanho, forma, textura, entre outras). Essa análise de materiais permitiu entender que a matéria-prima utilizada é determinante para o sucesso ou fracasso da adaptação do recurso, devendo, portanto, ser item obrigatório no instrumento de avaliação.

O segundo passo para obtenção de conhecimento decorreu a partir da leitura dos Livros do Portal de Ajudas Técnicas para Educação: equipamento e material pedagógico para educação, capacitação e recreação da pessoa com deficiência física, volumes 1,2 e 4 (MANZINI; SANTOS, 2002; MANZINI; DELIBERATO, 2004; MANZINI; DELIBERATO, 2007). Esses materiais forneceram fotos dos recursos adaptados e a descrição da matériaprima utilizada para a adaptação, além da indicação da estratégia que poderia ser utilizada em cada aplicação do recurso. Nesse sentido, os objetivos da leitura desses materiais foram: 1) conhecer os tipos de matérias-prima que foram utilizados para a adaptação dos recursos descritos; 2) identificar as relações entre o objetivo da adaptação e o objetivo da atividade pedagógica pretendida; 3) observar as dimensões físicas que cada recurso possuía, ou seja, diferentes tamanhos, cores e formas para atender às necessidades do aluno para o qual o recurso foi adaptado; e 4) identificar as estratégias planejadas para a utilização de cada recurso.

O terceiro passo foi buscar na literatura, instrumentos de avaliação já publicados. Nessa etapa da pesquisa foram identificados instrumentos de avaliação para serem utilizados na área da educação especial, com diferentes objetivos: para avaliar a acessibilidade arquitetônica (AUDI, 2004; AUDI, MANZINI, 2006); para avaliar alunos com baixa visão e 
deficiência física no ensino infantil (BRUNO, 2005); para avaliar habilidades comunicativas em situação familiar (DELAGRACIA, 2007) e em situação escolar (DE PAULA, 2007); para avaliar a preensão de alunos com paralisia cerebral visando à adaptação de recursos pedagógicos (SANKAKO; OLIVEIRA; MANZINI, 2007) e para avaliar a acessibilidade do aluno com paralisia cerebral ao computador (LOURENÇO, 2008), sempre enfocando aspectos educacionais, mas nenhum com o objetivo específico de avaliar o aluno com paralisia cerebral e o seu contexto acadêmico, visando adaptar um recurso pedagógico. No entanto, os instrumentos mencionados contribuíram para a elaboração estrutural do atual instrumento, fornecendo subsídios para a elaboração de itens de avaliação.

O quarto passo foi buscar na literatura referências sobre adaptação de recursos pedagógicos, ensino, aprendizagem e características sobre o aluno com paralisia cerebral.

Todos esses materiais contribuíram para que os itens propostos na primeira versão do instrumento avaliassem não só as características motoras, cognitivas e pedagógicas do aluno com paralisia cerebral, mas, também, itens sobre os contextos sociais, familiares e escolares.

\subsection{Estruturação da primeira versão do instrumento}

De início, optou-se por basear a estruturação do atual instrumento nos protocolos de De Paula (2007) e Delagracia (2007), desenvolvendo uma avaliação dispostas em quadros. Depois, foi necessário optar por uma maneira de sistematizar a avaliação em dimensões de habilidades para facilitar a utilização do instrumento, já que havia dezessete dimensões avaliativas diferentes. Encontraram-se, então, as considerações feitas por Manzini (1990/1991), que mesmo sendo específicas para a construção de roteiro de entrevista e não de avaliação, contribuíram para a sistematização das áreas de habilidade. Essa contribuição justifica-se, por acreditar que, para a elaboração de ambos os materiais, os mesmos cuidados devem ser considerados, já que na elaboração dos dois instrumentos o que se pretende é a compreensão das sentenças diminuindo a possibilidade de coletar informações falsas ou equivocadas. Dessa maneira, seguindo as orientações desse trabalho, foram colocadas frases introdutórias antes de cada tema questionado, já que, para o autor, são essas frases que informam o sujeito sobre o assunto que será abordado, e alertam quando haverá mudança de um tema para outro, evitando confusões entre temas diferentes. 
Outra característica da primeira versão do instrumento foi a necessidade de estipular um único critério de ordenação para todas as dimensões avaliativas, assim, procurou-se ordená-las de modo que os itens avaliativos iniciassem com a resposta que representasse a habilidade completa da ação, seguindo gradualmente, até apresentar a última resposta com a mínima habilidade esperada para aquela ação específica. Bunchaft e Cavas (2002, p. 127) descreveram esse procedimento quando definiram as escalas de avaliação:

Escala de avaliação é um instrumento de medida psicológica no qual se ordenam aspectos qualitativos de indivíduos ou objetos de modo a haver uma correspondência numérica; o avaliador deve posicionar o indivíduo ou objeto cujas características estão sendo julgadas em determinado ponto de um contínuo ou numa categoria pertencente a uma série ordenada de categorias.

À título de exemplo, essa ordenação pode ser observada nas cinco opções de respostas que foram fornecidas para responder sobre a habilidade de leitura do aluno:

1) O aluno é capaz de ler?

2) O aluno lê os nomes de pessoas do seu convívio?

3) O aluno lê seu próprio nome?

4) $\mathrm{O}$ aluno lê as iniciais do seu próprio nome?

5) O aluno lê as vogais?

Dessa maneira, a primeira versão do instrumento foi formada por 61 folhas divididas em: a) uma folha para a capa do instrumento com o nome do estudo, o nome da pesquisadora, o nome do orientador, a instituição de fomento e a instituição de ensino; b) uma folha de apresentação do objetivo do instrumento e para quem era destinado; c) duas folhas com os nomes das dimensões de avaliação; d) 57 páginas dispostas em quadros, totalizando 110 itens avaliativos divididos em dezessete dimensões: 1) Dimensão acadêmica: potencialidades do aluno; 2) Dimensão acadêmica: material pedagógico; 3) Dimensão da linguagem e comunicação; 4) Dimensão cognitiva; 5) Dimensão cognitiva: conhecimentos matemáticos; 6) Dimensão social; 7) Dimensão motora: posicionamento; 8) Dimensão motora: material pedagógico; 9) Dimensão sensorial; 10) Dimensão emocional; 11) Dimensão do contexto familiar; 12) Dimensão das preferências individuais; 13) Dimensão dos recursos do ambiente e do professor; 14) Objetivos de ensino frente à avaliação; 15) Categorias para a adaptação ou confecção do recurso; 16) Reflexões para a escolha da estratégia de ensino e 17) Estratégias de ensino. 


\subsection{Aplicação da primeira versão do instrumento}

No dia 30 de outubro de 2008 foi marcada uma reunião com as cinco participantes em uma sala de aula na própria Universidade. Naquela ocasião, o instrumento foi apresentado pela pesquisadora, que leu pausadamente a folha inicial, as folhas de apresentação e os itens avaliativos do instrumento.

Depois da apresentação do material, cada participante recebeu uma cópia impressa e encadernada do instrumento e, em seguida, foi combinado que cada uma levaria o instrumento para que pudesse avaliar o aluno do estágio. Nesse dia, um período de 14 dias foi estipulado para que as participantes realizassem a avaliação e, posteriormente, comparecessem a uma reunião para a análise da utilização do instrumento.

A seguir, estão disponibilizadas no Quadro 1, informações a respeito das participantes que utilizaram a primeira versão do instrumento; e no Quadro 2, informações a respeito dos alunos avaliados pelas participantes.

Para garantir o sigilo das participantes e dos alunos avaliados, os nomes das participantes foram substituídos pelas iniciais P1, P2, P3, P4, e P5, e os nomes dos alunos foram substituídos pelas iniciais A1, A2, A3, A4 e A5. Dessa maneira, a P1 avaliou o aluno A1, a P2 avaliou o aluno A2, e assim, consecutivamente.

\begin{tabular}{|l|l|l|l|l|}
\hline Nome & Idade & $\begin{array}{l}\text { Conclusão } \\
\text { do curso de } \\
\text { Pedagogia }\end{array}$ & \multicolumn{1}{|c|}{ Habilitações } & Outras informações: \\
\hline P1 & 26 & $\begin{array}{l}\text { Julho de } \\
2009\end{array}$ & $\begin{array}{l}\text { Educação Especial: } \\
\text { Deficiência Física }\end{array}$ & Nível básico em Libras - 2008 \\
\hline P2 & 24 & $\begin{array}{l}\text { Julho de } \\
2009\end{array}$ & $\begin{array}{l}\text { Educação Especial: } \\
\text { Deficiência Física }\end{array}$ & $\begin{array}{l}\text { Contato com a área de comunicação } \\
\text { alternativa (estágio). }\end{array}$ \\
\hline P3 & 24 & $\begin{array}{l}\text { Julho de } \\
2009\end{array}$ & $\begin{array}{l}\text { Educação Especial: } \\
\text { Deficiência Física }\end{array}$ & $\begin{array}{l}\text { Magistério 2003 } \\
\text { Alfabetização em Braille }-2003 \\
\text { Técnico em mobilidade e locomoção - } \\
\text { 2003 } \\
\text { Nível básico em Libras - 2005 } \\
\text { Contato com a área de comunicação } \\
\text { alternativa (estágio). }\end{array}$ \\
\hline P4 & 32 & $\begin{array}{l}\text { Julho de } \\
2009\end{array}$ & $\begin{array}{l}\text { Educação Especial: } \\
\text { Deficiência Física }\end{array}$ & $\begin{array}{l}\text { Formação para } \\
\text { magistério; } \\
\text { Administração } \\
\text { escolar }\end{array}$ \\
\hline P5 & 45 & 1985 & & \\
\hline
\end{tabular}

Quadro 1- Características das participantes da pesquisa 


\begin{tabular}{|c|c|c|c|}
\hline NOME & $\begin{array}{lll}\begin{array}{l}\text { Diagnóstico } \\
\text { avaliado }\end{array} & \text { do aluno } \\
\end{array}$ & $\begin{array}{lll}\text { Idade } & \text { do } & \text { aluno } \\
\text { avaliado } & & \\
\end{array}$ & Informações: \\
\hline A1 & $\begin{array}{l}\text { Paralisia } \quad \text { Cerebral } \\
\text { Espástica (Quadriplégico) }\end{array}$ & 30 anos & $\begin{array}{l}\text { Atendimento } \\
\text { pedagógico no CEES. }\end{array}$ \\
\hline A2 & Síndrome 9p-. & 12 anos & $\begin{array}{l}\text { Atendimento } \\
\text { pedagógico no CEES. }\end{array}$ \\
\hline A3 & $\begin{array}{l}\text { Paralisia Cerebral } \\
\text { Espástica (Diplégico) }\end{array}$ & 7 anos & $\begin{array}{l}\text { Primeiro ano do Ensino } \\
\text { Fundamental; } \\
\text { Atendimento } \\
\text { pedagógico no CEES. }\end{array}$ \\
\hline A4 & $\begin{array}{l}\text { Paralisia Cerebral } \\
\text { Espástica (Diplégico) }\end{array}$ & 7 anos & $\begin{array}{l}\text { Primeiro ano do Ensino } \\
\text { Fundamental; } \\
\text { Atendimento } \\
\text { pedagógico no CEES. }\end{array}$ \\
\hline A5 & $\begin{array}{ll}\text { Paralisia } & \text { Cerebral: } \\
\text { (hemiplégico) } & \end{array}$ & 23 anos & $\begin{array}{l}\text { Atendimento } \\
\text { pedagógico no CEES; } \\
\text { Cursando a Educação } \\
\text { de Jovens e Adultos } \\
\text { (EJA). }\end{array}$ \\
\hline
\end{tabular}

Quadro 2- Características dos alunos avaliados com o uso da primeira versão do instrumento.

\subsection{Avaliação da primeira versão do instrumento}

No dia 13 de novembro de 2008, houve a primeira reunião entre as participantes e a pesquisadora, comparecendo apenas três participantes. No dia 27 de novembro de 2008, houve uma nova reunião, comparecendo todas as participantes, sendo as duas reuniões gravadas.

Para a construção da segunda versão do instrumento foram consideradas as anotações feitas pela pesquisadora, as gravações das reuniões e os instrumentos preenchidos.

Para conduzir as reuniões, o instrumento foi analisado folha por folha, guiado por perguntas norteadoras:

1. Vocês acham que há itens que precisam ser suprimidos/substituídos/modificados?

2. Vocês preencheram as folhas na sequência, ou foi em áreas específicas que vocês já conheciam?

3. Ficou algum item sem preencher? Por quê?

4. Há algum item que ficaria mais fácil de ser entendido se fosse acrescentada figura ilustrativa? 


\subsection{Reformulação da primeira versão para a construção da segunda versão}

As modificações realizadas na primeira versão do instrumento para a construção da segunda versão foram feitas a partir das dúvidas e sugestões das participantes. No entanto, essas informações não foram consideradas como definitivas, pois, caso fosse necessário, as exclusões e as antigas formatações seriam retomadas para a reconstrução da próxima versão seguinte do instrumento.

De acordo com as dúvidas e sugestões, a segunda versão do protocolo foi construída, com as principais modificações:

1) Mudança na ordem das áreas de conhecimento no instrumento;

2) Exclusão de itens que se repetiam;

3) Inclusão de itens que faltavam;

4) Inserção da escala numérica identificando o número correspondente ao grau de desempenho da habilidade avaliada (BUNCHAFT; CAVAS, 2002);

5) Reescrita de sentenças que apresentavam dupla interpretação;

6) Modificação de sentenças que deixaram seu lugar de origem para serem níveis avaliativos dentro de uma área geral, deixando a tabela mais operacional;

7) Modificação do comando sobre as anotações adicionais, observações específicas ou dificuldade do aluno para a escolha de um único comando;

8) Exclusão da linha final "sugestão para atividade", pois esse item já era avaliado no final do instrumento;

9) Exclusão da maioria das setas indicativas que não eram necessárias;

10) Substituições de verbos de ação nas sentenças, por outros mais específicos sobre o que se pretendia avaliar;

11) Retirada de palavras depreciativas;

12) Redefinição de tabelas.

Uma das primeiras modificações da primeira versão do instrumento para a construção da segunda versão foi o acréscimo do número de páginas no índice, que havia ficado sem numeração. Essa modificação foi necessária, pois, apesar de o instrumento ser 
paginado, era gasto um tempo considerável ao procurar por uma área específica, sendo preciso manipular todas as folhas do instrumento.

Outra modificação realizada foi a mudança do primeiro título. Na primeira versão, estava como "área acadêmica: potencialidades do aluno", no entanto, no momento da construção da segunda versão, a modificação para "área cognitiva: potencialidade do aluno" ficou mais adequada. Essa modificação foi necessária para que a tabela pudesse abranger a parte cognitiva, incluindo a parte específica da linguagem, conhecimentos matemáticos, discriminação de figuras e potencialidades em compreender fatos históricos, que na primeira versão ficaram isolados da parte da escrita e leitura.

Dessa forma, observa-se que na primeira versão, os primeiros quatro itens eram dispostos da seguinte maneira:

- $\quad$ Área acadêmica: potencialidades do aluno

○ Habilidade em relação ao desenho,

○ Habilidade em relação a leitura;

○ Habilidade em relação à escrita;

- Produção de texto, frase e palavras;

- Área acadêmica: material pedagógico

2.1) Auxiliares da escrita,

2.2) Avaliação sobre o tipo de letra em atividades impressas;

- $\quad$ Área da linguagem e comunicação

3.1) Habilidade de comunicação;

3.2) Parceiros de comunicação;

3.3) Regras gerais para comunicação;

3.4) Relato de fatos em diferentes tempos verbais.

4) Área cognitiva

4.1) Discriminação de figuras entre certa quantidade e cores;

4.2) Potencialidade em compreender fatos históricos e fatos que provavelmente ocorrerão no futuro; reconhecimento de personagens históricos e atuais da política ou reconhecimento de personagens da área artística;

4.3) Conhecimentos matemáticos.

Para o preenchimento do instrumento com as áreas de habilidade dispostas nessa ordem, as participantes tiveram dificuldades para utilizar o instrumento, pois, na ordem em que as habilidades estavam dispostas, elas se misturavam ao longo dos itens avaliados, como 
pode ser observado: 1) avaliação individual do aluno, independente do recurso pedagógico utilizado, como no caso da avaliação das habilidades para desenhar, escrever, ler, produzir texto, discriminação de figuras, potencialidade em compreender fatos e conhecimentos matemáticos; 2) avaliação individual do aluno, com o uso de recursos pedagógicos específicos, como no caso da avaliação das habilidades em relação aos auxiliares da escrita; 3 ) avaliação do aluno em um contexto de interação, como no caso da avaliação da área da habilidade de comunicação; regras gerais para comunicação e relato de fatos em diferentes tempos verbais.

Outro aspecto observado foi que as sentenças da subárea "auxiliares da escrita", que, como o nome sugeria, deveriam avaliar as potencialidades da escrita e seus auxiliares, não cumpriam esses objetivos. Ao contrário, essas sentenças avaliavam as potencialidades inerentes à leitura, compreensão de texto e ao uso de material pedagógico, e, que, portanto, deveriam estar em outra área de habilidade. Por isso, suas sentenças foram excluídas pela área "potencialidade de leitura", sendo necessária a modificação do seu nome, que antes era "habilidade em relação a leitura" para "habilidades em relação a leitura: material pedagógico".

Diante de tanta modificação, considerou-se necessário refazer a disposição das áreas de habilidade em uma ordem que facilitasse a compreensão e o preenchimento de suas sentenças. Assim, a segunda versão ficou como segue (com o nome de algumas áreas e subáreas já modificadas).

1) Área cognitiva: potencialidades do aluno

1.1) Habilidade em relação à interpretação de figuras, fotos ou objetos;

1.2) Habilidades em relação a leitura: material pedagógico;

1.3) Habilidades em relação à escrita;

1.4) Produção de texto, frase e palavra;

1.5) Discriminação de figuras entre certa quantidade e cores;

1.6) Potencialidade em compreender fatos históricos e fatos futuros, reconhecimento de personagens históricas e atuais;

1.7) Conhecimentos matemáticos;

2) Área da linguagem e comunicação

2.1) Habilidade de comunicação;

2.2) Parceiros de comunicação;

2.3) Regras gerais para comunicação; 
2.4) Relato de fatos em diferentes tempos verbais (com o uso da fala oral, com figuras da comunicação alternativa ou outro tipo de comunicação funcional);

3) Área acadêmica

3.1) Observações específicas sobre a atividade;

3.2) Avaliação sobre o tipo de letra em atividades impressas.

$\mathrm{Na}$ estrutura das tabelas também houve consideráveis modificações, como, por exemplo, a retirada da coluna com o símbolo “( )", pois, as participantes ficaram confusas se poderia ser deixada em branco, caso não fizesse parte do nível do aluno. No lugar dessa exclusão, foram adicionadas duas colunas, que poderiam aparecer na tabela de acordo com a necessidade do item avaliativo. Assim, caso o item avaliativo não necessitasse de uma avaliação complementar, foi adicionada a coluna com alternativas "sim ou não", para avaliar se o item era ou não correspondente ao aluno.

No Quadro 3, observa-se um exemplo da primeira versão do instrumento e no Quadro 4, observa-se um exemplo da segunda versão do instrumento, com as modificações já incorporadas.

\begin{tabular}{|l|c|c|c|c|c|}
\hline \multicolumn{2}{|c|}{ Itens para avaliação } & \multicolumn{2}{c|}{ ELE TEM DIFICULDADE? } & Caso o aluno faca a atividade com dificuldade, \\
\cline { 2 - 4 } & Muita & Pouca & Nenhuma & \\
\hline $\begin{array}{l}\text { 1.1) Monta uma história com } \\
\text { sequência de .desenhos. }\end{array}$ & & & & \\
$\begin{array}{l}\text { Ex: Se é dado figuras sequenciais, por } \\
\text { exemplo, uma com o menino andando, } \\
\text { outra com o menino caindo e a outra } \\
\text { com o menino chorando, ele coloca } \\
\text { na sequência correta? }\end{array}$ & ( ) & ( ) & ( ) & ( ) & \\
\hline
\end{tabular}

Quadro 3 - Exemplo da Seção principal da primeira versão

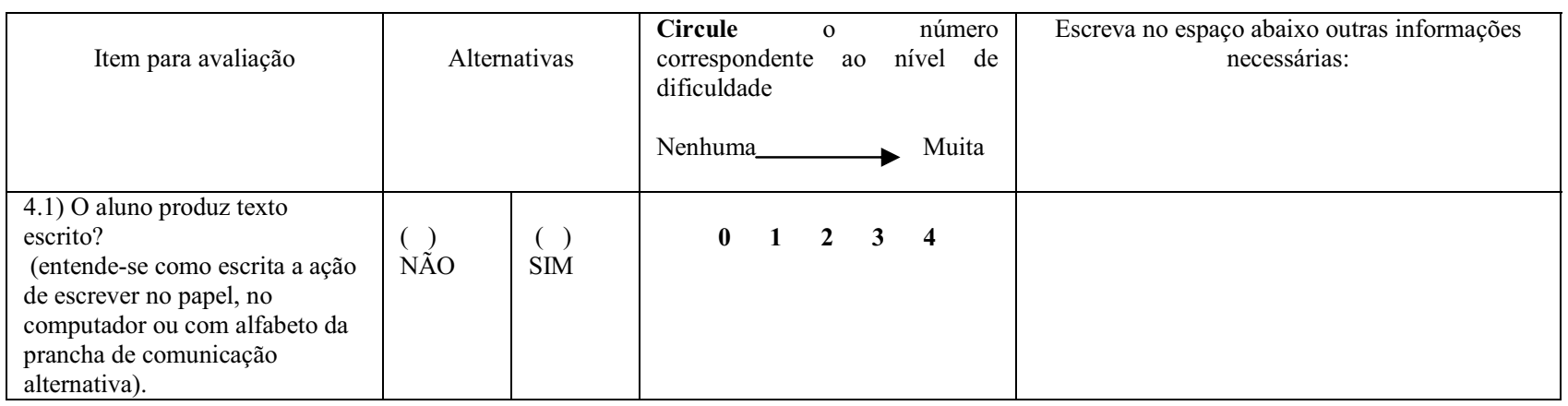

Quadro 4 - Exemplo da Seção principal da segunda versão

No entanto, se o item avaliativo necessitasse de especificação era adicionada a coluna "níveis de habilidade", para que o nível do aluno pudesse ser avaliado. Como exemplo dessa mudança, observa-se que na área "habilidade em relação ao desenho" intitulada na 
segunda versão como "habilidade em relação à interpretação de figuras, fotos e objetos", apenas inserir as variáveis "sim e não" não eram suficientes para avaliar a potencialidade do aluno, pois, para essa avaliação era necessário saber, por exemplo, como o aluno realizava uma determinada atividade avaliada e quais materiais eram necessários para o planejamento do recurso pedagógico, já que essa era a principal finalidade do instrumento.

Nesse sentido, julgou-se necessário extinguir o quadro da "dimensão acadêmica: material pedagógico", e o quadro da dimensão intitulada "auxiliares da escrita" para aproveitar seus itens avaliativos em uma só dimensão. A junção dessas duas dimensões na segunda versão do instrumento forneceu ao avaliador uma lista mais completa de opções, para que ele escolhesse a que melhor descrevesse a habilidade do seu aluno. No Quadro 5, observa-se um exemplo da seção principal da segunda versão do instrumento com as modificações descritas anteriormente:

\begin{tabular}{|c|c|c|}
\hline Itens para avaliação & $\begin{array}{c}\text { Habilidade } \\
\text { (marque apenas o nível correspondente ao seu aluno) }\end{array}$ & $\begin{array}{l}\text { Escreva no espaço abaixo } \\
\text { outras informações: }\end{array}$ \\
\hline \multirow{5}{*}{$\begin{array}{l}\text { Ex: Ao fornecer figuras sequenciais, por exemplo, } \\
\text { uma com o gato andando, outra com um peixe na } \\
\text { janela e a outra com o gato de barriga cheia, e é } \\
\text { lido o texto referente as figuras mencionadas, ele } \\
\text { as coloca na sequência correta? }\end{array}$} & $\begin{array}{l}\text { ( ) Sim, ele não tem dificuldade para realizar essa } \\
\text { atividade. }\end{array}$ & \\
\hline & $\begin{array}{l}\text { ( ) Sim, mas ele precisa de fotos das cenas reais, pois ele } \\
\text { não reconhece desenhos. }\end{array}$ & \\
\hline & $\begin{array}{l}\text { ( ) Sim, mas ele precisa de objetos em miniatura que } \\
\text { representam o real. }\end{array}$ & \\
\hline & $\begin{array}{l}\text { ( ) Sim, mas ele precisa trabalhar com objetos em } \\
\text { tamanho que representem o tamanho real. }\end{array}$ & \\
\hline & ( ) Não, ele não faz essa atividade & \\
\hline
\end{tabular}

Quadro 5 - Exemplo da Seção principal da segunda versão

Outra modificação realizada em relação à estrutura das tabelas foi a substituição dos comandos "ele tem dificuldade? muita, pouca, nenhuma" pelo comando "circule o número correspondente ao nível de dificuldade", construído por medidas escalares, do tipo escala numérica. Essa modificação foi baseada nos estudos de Bunchaft e Cavas (2002), que sugeriram a utilização de medidas escalares como sendo as mais utilizadas para medir atitudes, traços de personalidade e avaliações de desempenho, os autores as classificaram em cinco categorias: numérica, gráfica, escolha forçada, padrão e pontos acumulados.

Para justificar essa mudança no presente estudo, observou-se que as opções "muita, pouca, nenhuma" limitavam a avaliação do nível de desempenho do aluno, como, por exemplo, quando em uma primeira avaliação, foi constatado que o aluno tinha "muita" dificuldade para realizar uma determinada tarefa, e, em uma segunda avaliação, o aluno tem um ganho no desenvolvimento, mas não o suficiente para que o avaliador indique a opção "pouca" dificuldade em relação à habilidade avaliada. Dessa maneira, o avaliador teria que escolher a mesma opção, e quando comparadas a primeira e a segunda avaliação, os 
resultados em relação à eficácia da sua intervenção poderiam gerar dúvidas, já que a avaliação não apontaria nenhum progresso no desenvolvimento do aluno, como pode ser observado no Quadro 6:

\begin{tabular}{|l|c|c|c|c|c|}
\hline \multicolumn{2}{|c|}{ Item para avaliação } & \multicolumn{2}{|c|}{ Ele tem dificuldade? } & \multirow{2}{*}{ Caso o aluno faca a atividade com dificuldade, } \\
\cline { 2 - 4 } & Muita & Pouca & Nenhuman & \\
\hline $\begin{array}{l}\text { 4.1) O aluno produz texto } \\
\text { escrito (entende-se escrito } \\
\text { como a ação de escrever no } \\
\text { papel, no computador palavras: } \\
\text { alfabeto da comunicação } \\
\text { alternativa). }\end{array}$ & ( ) & ( ) & ( ) & ( ) & \\
\hline
\end{tabular}

Quadro 6 - Exemplo da Seção principal da primeira versão

Da mesma maneira, se o avaliador utilizasse a segunda versão do instrumento, optando por circular o grau " 4 " de dificuldade, e, em uma reavaliação, o aluno apresentasse um pequeno ganho em seu desenvolvimento, permitindo que o avaliador optasse por circular o grau “3”. Ao comparar a primeira avaliação com a reavaliação, o instrumento indicaria que, apesar de o aluno ainda apresentar dificuldades em relação à habilidade, houve uma melhora no seu desenvolvimento, concluindo que a sua intervenção estava sendo adequada, como pode ser observado no Quadro 7:

\begin{tabular}{|c|c|c|c|c|c|}
\hline Item para avaliação & $\begin{array}{c}\text { Habilidade } \\
\text { (marque apenas o que corresponde ao nível do aluno) }\end{array}$ & \multicolumn{4}{|c|}{$\begin{array}{l}\text { Circule o número correspondente } \\
\text { ao nível de dificuldade para } \\
\text { realizar a atividade } \\
\text { Nenhuma }\end{array}$} \\
\hline $\begin{array}{l}\text { 3.1) Como é a escrita do seu aluno? } \\
\text { Entende-se nesse item como } \\
\text { habilidade de escrita como: escrita } \\
\text { com lápis, ou com computador ou } \\
\text { com material da comunicação } \\
\text { alternativa. }\end{array}$ & $\begin{array}{l}\text { ( ) A escrita está adequada às regras ortográficas, apresentando } \\
\text { um baixo índice de erros em relação a escrita total do texto. } \\
\text { Ex: Ele não tem grandes dificuldades com a escrita, pois, } \\
\text { escreve bem, tendo poucos erros ortográficos. }\end{array}$ & $\mathbf{0}$ & 2 & 3 & 4 \\
\hline
\end{tabular}

Quadro 7 - Exemplo da Seção principal da segunda versão

O nome da última coluna, que tinha como finalidade fornecer um espaço extra para outras informações que não tivessem sido contempladas nas sentenças, foi substituída, pois uma das sugestões das participantes era que toda fileira que tivesse o objetivo de coletar informações adicionais do avaliador deveria manter um mesmo título, já que havia lugares em que era pedido para que o avaliador descrevesse as dificuldades do aluno e, em outros, para o avaliador descrever informações que fossem necessárias. 
Nesse sentido, duas das participantes que avaliaram o instrumento disseram que não haviam percebido mais de um título para esse tipo de fileira, seguindo o primeiro comando observado. Essa questão nos remete a uma situação muito comum que ocorre em provas de admissão em concursos e/ou vestibulares. Coloca-se um mesmo comando em muitas questões seguidas, como, por exemplo, de que há uma resposta verdadeira entre as falsas, e após um número considerável de ocorrência, substitui-se o comando, colocando que há uma resposta falsa entre as verdadeiras, confundindo os candidatos, que já haviam interiorizado o primeiro comando.

Outra sugestão, foi a retirada da última coluna (quando houvesse) com a sentença "sugestões para atividades"; essa sentença foi identificada como repetitiva, visto que, ao final do instrumento, já havia a parte sobre a estratégia de ensino que abarcava essa questão.

Em relação aos itens, foram feitas algumas alterações na escrita das sentenças, procurando deixá-las autoexplicativas, por exemplo, a sentença: "após a leitura de uma história, o aluno faz desenhos de acordo com a história ouvida?". Houve questionamentos sobre o verbo de ação utilizado nessa sentença, pois, uma das participantes relatou que o seu aluno não fazia o desenho por causa da limitação motora, e não por incapacidade cognitiva. Observou-se então, que esse item trazia dois objetos de avaliação, sendo que um era avaliar a habilidade do aluno em fazer desenhos (ato motor) e o outro, avaliar se ele era capaz de reconstruir uma história após escutá-la. Real e Parker (2000) descreveram que esse tipo de pergunta, com duas ou mais questões em uma única sentença, causa confusão para quem está respondendo, já que o entrevistado tende a optar por uma das duas opções. Assim, já que o objetivo da construção dessa sentença era o segundo questionado, houve a necessidade de modificar a escrita, para a forma: "após a leitura de uma história, o aluno monta uma sequência de acordo com a história ouvida?"

Uma das modificações da sentença "O desenho do aluno tem semelhança com o que ele pretende desenhar? Ex: Quando o aluno desenha uma pessoa, já é possível distinguir braços e cabeça?", também foi em relação à escrita, já que sugeria duas avaliações, sendo uma referente à potencialidade motora do aluno e a outra referente ao conhecimento de parte e todo, que era o seu objetivo, como pode ser observado no Quadro 8:

\begin{tabular}{|c|c|c|c|c|}
\hline \multirow{2}{*}{ Itens para avaliação } & \multicolumn{3}{|c|}{ ELE TEM DIFICULDADE? } & \multirow{2}{*}{$\begin{array}{l}\text { Caso o aluno faca a atividade com } \\
\text { dificuldade, descreva-as em poucas palavras: }\end{array}$} \\
\hline & Muita & Pouca & Nenhuma & \\
\hline
\end{tabular}




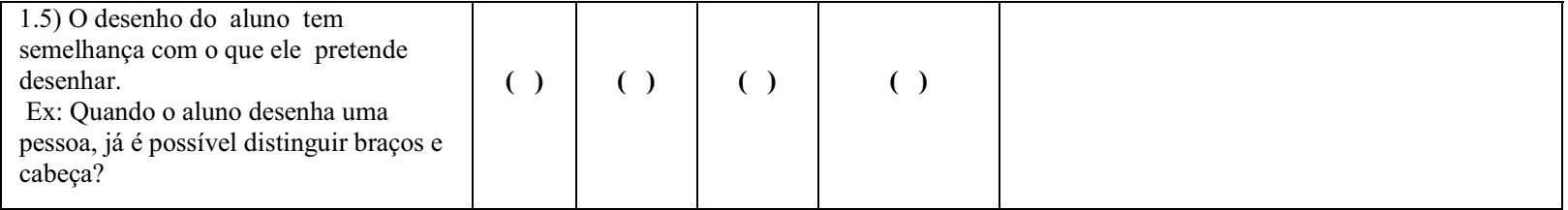

Quadro 8 - Exemplo da Seção principal da primeira versão

Sobre esse tipo de avaliação, Bunchaft e Cavas (2002) relataram que os princípios gerais para a construção de escalas de avaliação são que os itens devem ser afirmativos, ou seja, capazes de dizer aquilo que são e o que não são; além de serem exatos, ou seja, capazes de descrever o que querem definir. Dessa maneira, o item avaliativo dessa tabela passou a ser: “1.5) O aluno monta um quebra-cabeça?”. Para uma melhor compreensão, foi acrescentada a definição de quebra-cabeça disponibilizada pelo dicionário Houaiss (HOUAISS, 2001). Além disso, foram acrescentadas duas colunas extras que avaliavam a necessidade ou não do auxílio de material extra e de modelo para a realização da atividade, como observado no Quadro 9:

\begin{tabular}{|c|c|c|c|}
\hline $\begin{array}{l}\text { Itens para } \\
\text { avaliação }\end{array}$ & $\begin{array}{c}\text { Habilidade } \\
\text { (marque apenas o nível } \\
\text { correspondente ao seu aluno) }\end{array}$ & $\begin{array}{l}\text { Ele precisa de material auxiliar } \\
\text { para realizar essa atividade? }\end{array}$ & $\begin{array}{c}\text { Ele precisa de auxílio para realizar a } \\
\text { atividade? }\end{array}$ \\
\hline \multirow{5}{*}{$\begin{array}{l}\text { 1.5) O aluno } \\
\text { monta um } \\
\text { "quebra-cabeça?" } \\
\text { Quebra-cabeça: } \\
\text { jogo que consiste } \\
\text { em combinar } \\
\text { diferentes peças } \\
\text { para com elas } \\
\text { formar um todo, } \\
\text { que pode ser uma } \\
\text { figura. }\end{array}$} & $\begin{array}{l}\text { ( ) Sim, ele consegue montar um } \\
\text { quebra-cabeça com } 8 \text { ou mais } \\
\text { peças }\end{array}$ & \multirow{4}{*}{$\begin{array}{l}\text { ( ) Não, ele não precisa de } \\
\text { material auxiliar, pois, ele faz a } \\
\text { atividade com qualquer material. } \\
\text { ( ) Sim, ele precisa trabalhar com } \\
\text { fotos de cenas reais, pois ele não } \\
\text { reconhece desenhos. } \\
\text { ( ) Sim, ele precisa trabalhar com } \\
\underline{\text { fotos, e com auxílio de objetos em }} \\
\underline{\text { miniatura de cenas reais. }} \\
\text { ( ) Sim, ele precisa trabalhar com } \\
\underline{\text { fotos, e com auxílio de objetos em }} \\
\underline{\text { tamanho que representem o real. }}\end{array}$} & \multirow{4}{*}{$\begin{array}{l}\text { ( ) Sim, há necessidade que o modelo } \\
\text { permaneça na carteira no momento da } \\
\text { atividade } \\
\text { ( ) Sim, há necessidade de que ele } \\
\text { visualize o modelo antes da realização } \\
\text { da atividade. } \\
\text { ( ) Sim, ele precisa de instruções para } \\
\text { realizar a atividade. } \\
\text { ( ) Sim, ele precisa de dicas verbais } \\
\text { para realizar a atividade. } \\
\text { ( ) Sim, ele precisa de ajuda física para } \\
\text { realizar a atividade }\end{array}$} \\
\hline & $\begin{array}{l}\text { ( ) Sim, ele consegue montar um } \\
\text { quebra-cabeça com até } 6 \text { peças. }\end{array}$ & & \\
\hline & $\begin{array}{l}\text { ( ) Sim, ele consegue montar um } \\
\text { quebra-cabeça com até } 4 \text { peças. }\end{array}$ & & \\
\hline & $\begin{array}{l}\text { ( ) Sim, ele consegue montar um } \\
\text { quebra-cabeça com até } 2 \text { peças. }\end{array}$ & & \\
\hline & $\begin{array}{l}\text { ( ) Não, ele não faz essa } \\
\text { atividade. }\end{array}$ & Não preencher & \\
\hline
\end{tabular}

Quadro 9 - Exemplo da Seção principal da segunda versão

À área "habilidade em relação à leitura" foi acrescentada a frase "material pedagógico" e foram feitas modificações que permitiram um maior enxugamento dos itens. Assim, a tabela possuía cinco itens para avaliação, como pode ser observado no Quadro 10:

\begin{tabular}{|c|c|l|l|l|l|}
\hline \multirow{2}{*}{ Itens para avaliação } & \multirow{2}{*}{ Variáveis } & \multicolumn{2}{|c|}{ ELE TEM DIFICULDADE? } & \multicolumn{2}{|c|}{ Caso o aluno faça a atividade com } \\
\cline { 3 - 4 } & & Muita & Pouca & Nenhuma & $\frac{\text { dificuldade, descreva-as em poucas }}{\text { palavras: }}$ \\
\hline
\end{tabular}




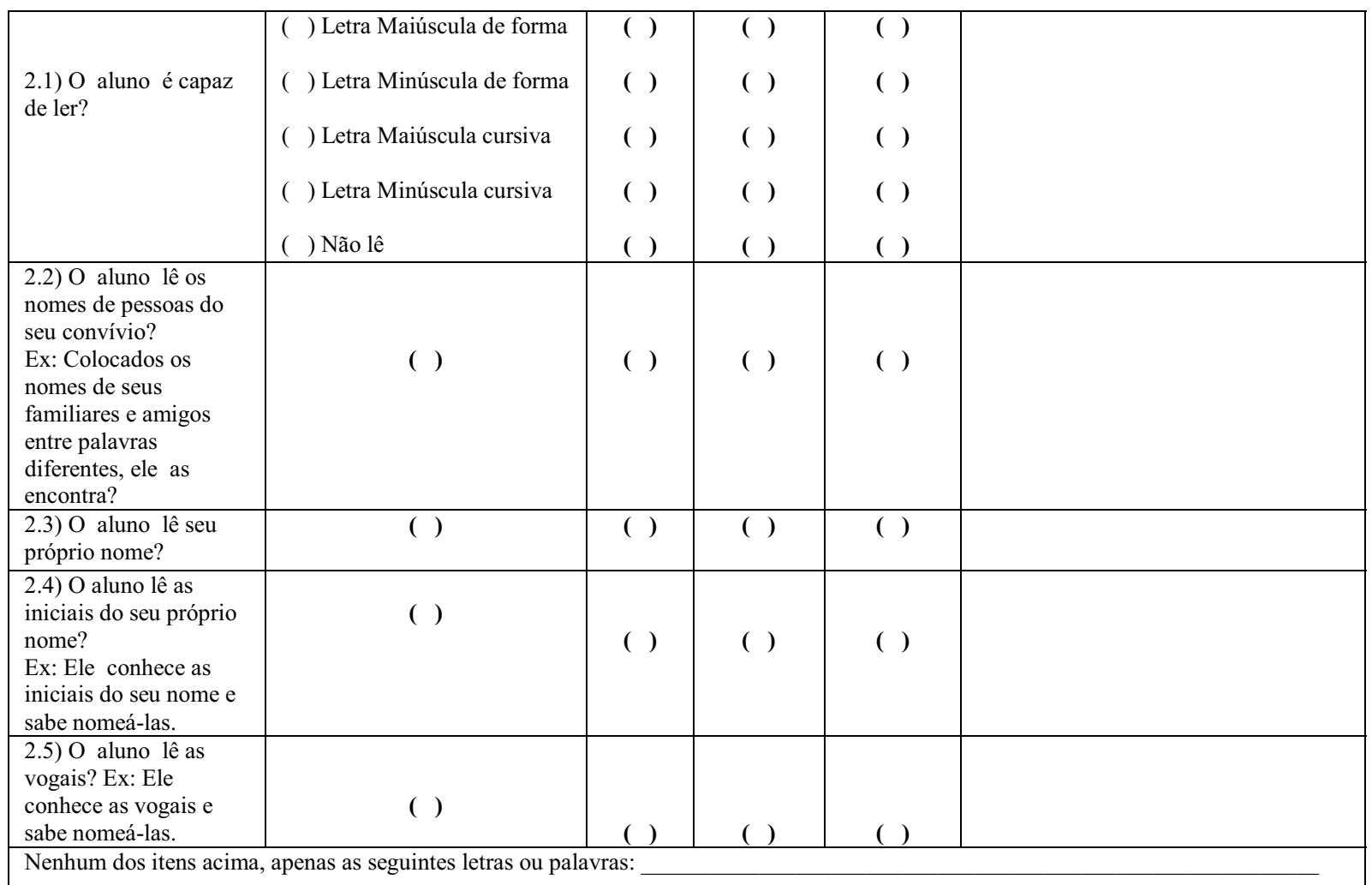

Quadro 10 - Exemplo da Seção principal da primeira versão

Na segunda versão, essa tabela passou a ter o único item "como é a leitura do aluno? (independente se ele é capaz de oralizar ou ler silenciosamente, o importante é saber se ele é capaz de interpretar um texto escrito)", como pode ser observado no Quadro 11, tornando-a mais abrangente e possibilitando que os outros itens de avaliação da primeira versão fossem incorporados à coluna das habilidades da segunda versão do instrumento:

\begin{tabular}{|c|c|c|c|}
\hline Itens para avaliação & $\begin{array}{l}\text { Habilidade } \\
\text { (marque apenas o nível correspondente ao } \\
\text { seu aluno) }\end{array}$ & Opções & $\begin{array}{l}\text { Escreva no espaço abaixo outra informação que você } \\
\text { julgue necessárias: }\end{array}$ \\
\hline \multirow{7}{*}{$\begin{array}{l}\text { 2.1) Como é a } \\
\text { leitura do aluno? } \\
\text { (independente se } \\
\text { ele é capaz de } \\
\text { oralizar ou ler } \\
\text { silenciosamente, o } \\
\text { importante é saber } \\
\text { se ele é capaz de } \\
\text { interpretar um texto } \\
\text { escrito) }\end{array}$} & $\begin{array}{l}\text { ( ) Ele lê qualquer tipo de texto que faça } \\
\text { parte do seu contexto. }\end{array}$ & \multirow{6}{*}{$\begin{array}{l}\text { ( ) Letra Maiúscula } \\
\text { de forma } \\
\text { ( ) Letra Minúscula } \\
\text { de forma } \\
\text { ( ) Letra Maiúscula } \\
\text { cursiva }\end{array}$} & \\
\hline & ( ) Ele lê textos simples & & \\
\hline & ( ) Ele lê sentenças curtas. & & \\
\hline & ( ) Ele lê o seu próprio nome. & & \\
\hline & $\begin{array}{l}\text { ( ) Ele reconhece as letras do seu próprio } \\
\text { nome. }\end{array}$ & & \\
\hline & $\begin{array}{l}\text { ( ) Ele reconhece as iniciais do seu } \\
\text { próprio nome. }\end{array}$ & & \\
\hline & ( ) Ele não lê. & Não preencher & \\
\hline \multicolumn{4}{|c|}{ Nenhum dos itens acima, apenas as seguintes letras ou palavras: } \\
\hline
\end{tabular}

Quadro 11 - Exemplo da Seção principal da segunda versão 
Além dessas modificações, à área da "habilidade de leitura" foi acrescentada, como pode ser observado no Quadro 12, uma tabela com a sentença "que tipo de auxílio o aluno necessita para realizar a compreensão de uma atividade escrita?" que foi uma reformulação da antiga "área acadêmica: material pedagógico" com as sentenças do item avaliativo da área "auxiliares da escrita", que foram excluídas dessa área e readaptadas em lugares mais adequados.

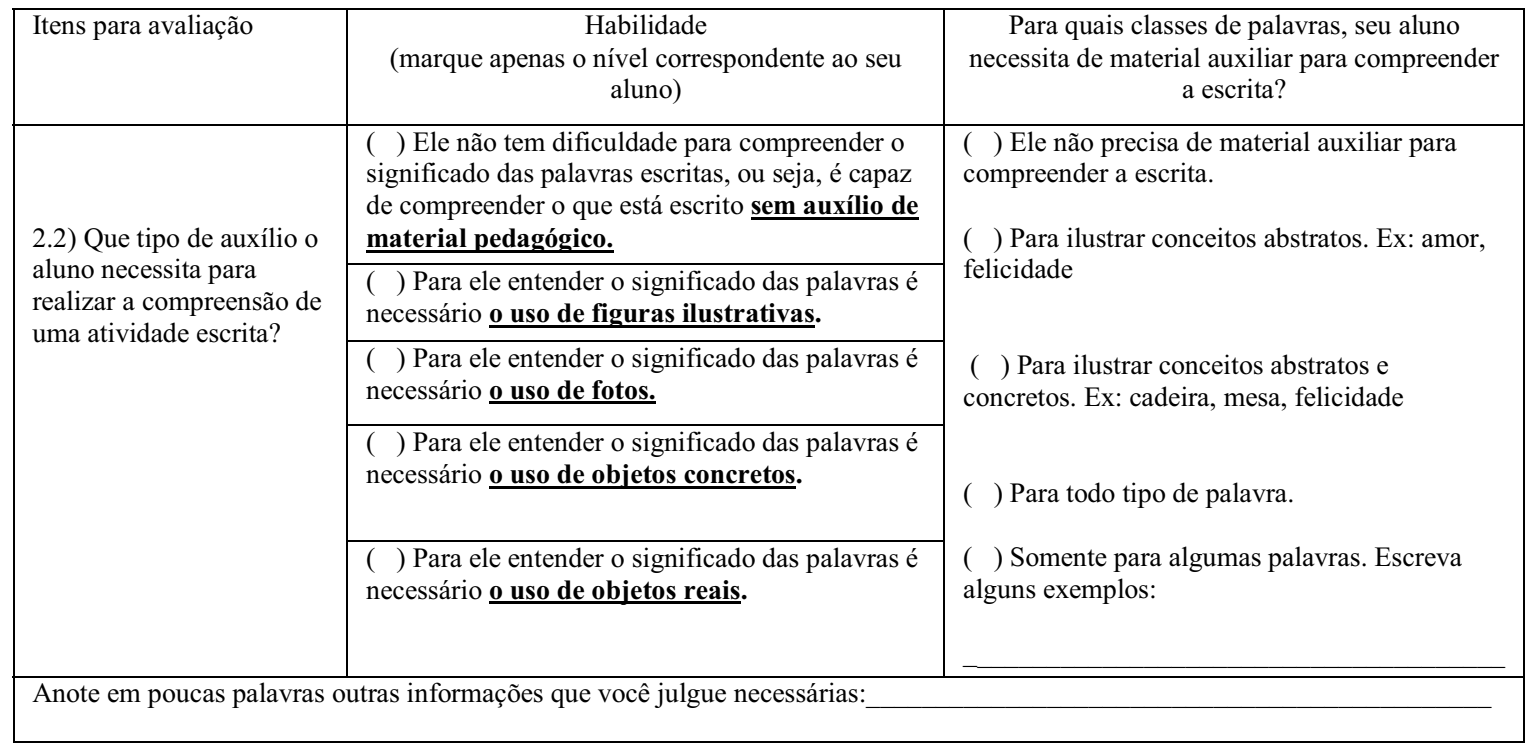

Quadro 12 - Exemplo da Seção principal da segunda versão

A área "habilidade em relação à escrita" também sofreu consideráveis modificações. Observa-se no Quadro 13, um exemplo da tabela da primeira versão, que possuía sete sentenças avaliativas:

\begin{tabular}{|c|c|c|}
\hline 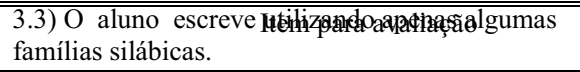 & ( ) & $\begin{array}{l}\text { Posqferba, qusaikiva no espaço abaixo outra informação que você julgue } \\
\text { importante: }\end{array}$ \\
\hline 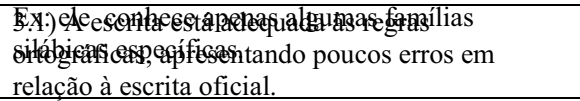 & ( ) & \\
\hline $\begin{array}{l}\text { Ex: Ele não tem grandes dificuldades com a } \\
\text { escrita, pois escreve bem, tendo poucos erros } \\
\text { ortográficos. }\end{array}$ & & \\
\hline $\begin{array}{l}\text { 3.2) Para escrever, o aluno utiliza a sílaba } \\
\text { inteira, mas há trocas silábicas. } \\
\text { Ex: Para escrever a palavra "gato", pode haver a } \\
\text { troca da sílaba "ga" por "ca" devido à sonoridade, } \\
\text { assim, a escrita pode ficar "cato". }\end{array}$ & ( ) & 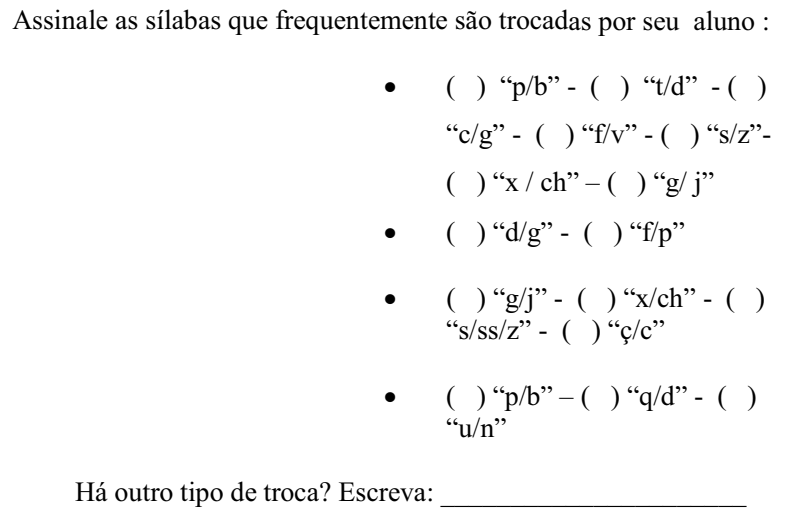 \\
\hline
\end{tabular}




\begin{tabular}{|c|c|c|}
\hline $\begin{array}{l}\text { 3.4) O aluno escreve utilizando as letras do seu } \\
\text { nome. } \\
\text { Ex: Carlos, ele usa as letras } \mathrm{c}-\mathrm{a}-\mathrm{r}-1-\mathrm{o}-\mathrm{s} \\
\text { para todas as palavras que ele escreve. }\end{array}$ & ( ) & \\
\hline $\begin{array}{l}\text { 3.5) } \mathrm{O} \text { aluno escreve utilizando apenas as } \\
\text { vogais. }\end{array}$ & ( ) & \\
\hline $\begin{array}{l}\text { 3.6) O aluno escreve utilizando as letras do } \\
\text { alfabeto aleatoriamente, ou seja, sem nenhuma } \\
\text { ligação com a sonoridade ou com a escrita. }\end{array}$ & ( ) & \\
\hline 3.7) $\mathrm{O}$ aluno não escreve. & ( ) & \\
\hline
\end{tabular}

Quadro 13 - Exemplo da Seção principal da primeira versão

A segunda versão, com as modificações, passou a ter apenas uma sentença geral que ficou intitulada de “como é a escrita do seu aluno?”. Seus antigos itens para avaliação da primeira versão foram incorporados aos níveis de habilidade dessa única sentença na segunda versão, sendo ainda necessário o acréscimo da sentença “o aluno faz garatujas" por sugestão das participantes, como pode ser observado no Quadro 14:

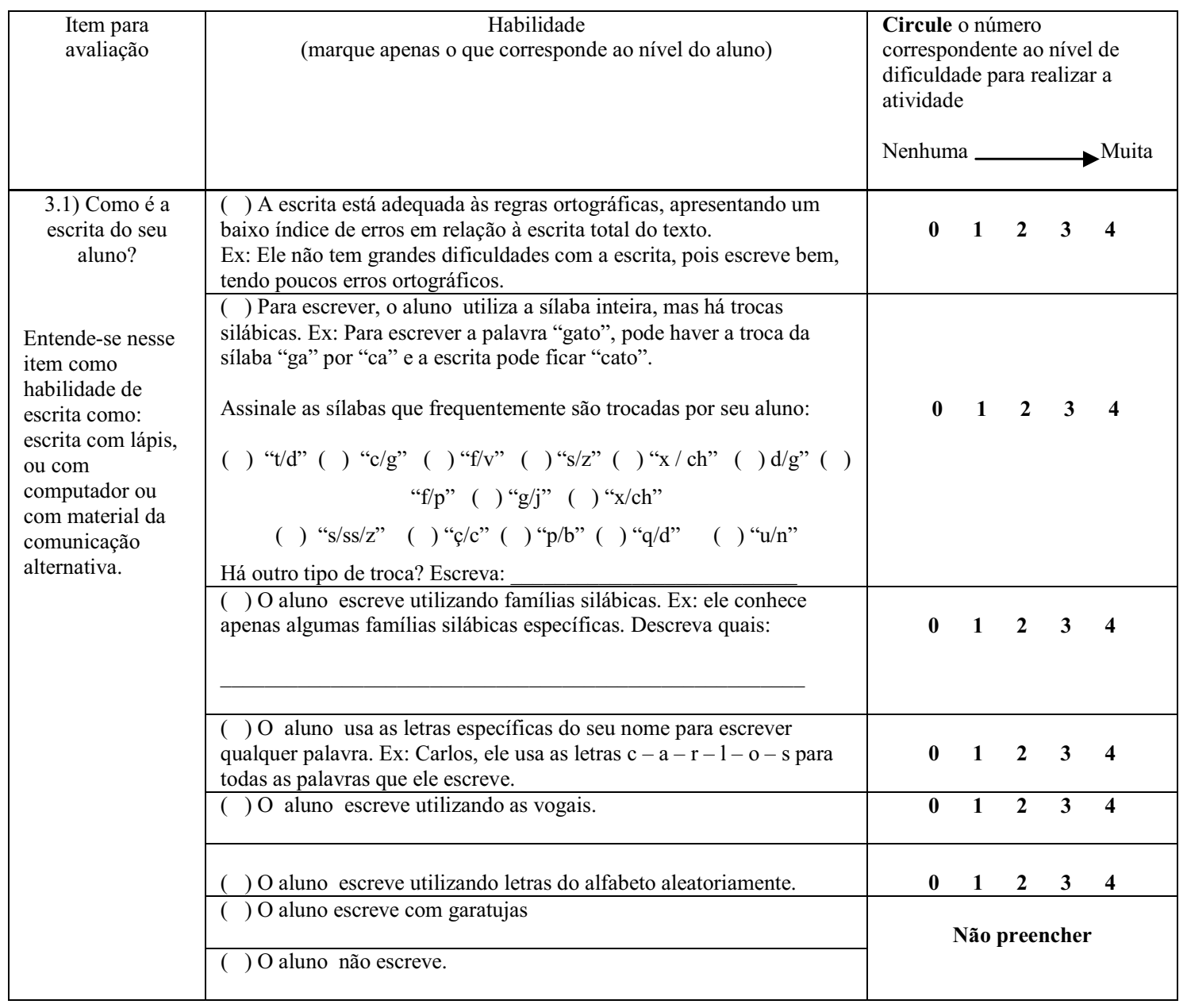

Quadro 14 - Exemplo da Seção principal da segunda versão. 
$\mathrm{Na}$ área "produção de texto, frase e palavra" houve o acréscimo das variáveis "sim e não". Esse acréscimo foi necessário pelo fato de ter havido dúvidas em relação ao preenchimento desses itens, partindo apenas do comando inicial contido na seção principal.

Dessa maneira, no Quadro 15, observa-se como a seção principal era na primeira versão:

\begin{tabular}{|l|c|c|c|c|c|}
\hline \multicolumn{2}{|c|}{ Item para avaliação } & \multicolumn{3}{c|}{ Ele tem dificuldade? } & Caso o aluno faca a atividade com dificuldade, \\
\cline { 2 - 4 } & Muita & Pouca & Nenhuma & \\
\hline $\begin{array}{l}\text { 4.1) O aluno produz texto escrito } \\
\text { (entende-se escrito como a ação de } \\
\text { escrever no papel, no computador ou com poucas palavras: } \\
\text { alfabeto da comunicação alternativa). }\end{array}$ & ( ) & ( ) & ( ) & ( ) & \\
\hline
\end{tabular}

Quadro 15 - Exemplo da Seção principal da primeira versão

E observa-se, no Quadro 16, como a seção principal ficou após as modificações:

\begin{tabular}{|c|c|c|c|c|c|c|c|c|}
\hline Item para avaliação & \multicolumn{2}{|c|}{ Alternativas } & $\begin{array}{r}\text { Circule } \\
\text { ao nível } \\
\begin{array}{r}\text { Nenhum } \\
\mathbf{0}\end{array} \\
\end{array}$ & \multicolumn{3}{|c|}{$\begin{array}{l}\text { Circule o número correspondente } \\
\text { ao nível de dificuldade }\end{array}$} & $\begin{array}{l}\text { pondente } \\
\text { Muita } \\
4\end{array}$ & $\begin{array}{c}\text { Escreva no espaço abaixo outras } \\
\text { informações que você julgue necessárias: }\end{array}$ \\
\hline $\begin{array}{l}\text { 4.1) O aluno produz texto escrito? } \\
\text { (entende-se como escrita a ação } \\
\text { de escrever no papel, no } \\
\text { computador ou com alfabeto da } \\
\text { comunicação alternativa). }\end{array}$ & NÃ & $\begin{array}{l}(\text { ( ) } \\
\text { SIM }\end{array}$ & $\mathbf{0}$ & 1 & 2 & 3 & 4 & \\
\hline
\end{tabular}

Quadro 16 - Exemplo da Seção principal da segunda versão

$\mathrm{Na}$ área "cognitiva", que continha o item "discriminação de figuras entre certa quantidade e cores", foi modificada a sentença que questionava se o aluno discriminava cores fortes. Esse termo "cores fortes" ficou vago e duvidoso, pois poderia ser entendido como cores como o vermelho, ou poderia ser entendido como a maneira como a cor era demonstrada, sendo apagada ou vibrante. Real e Parker (2000) nos alertaram que é preciso evitar a ambiguidade nas perguntas que é ocasionada pelo uso de frases ou palavras vagas. Dessa maneira, optou-se pela sentença, o aluno discrimina "apenas cores específicas, especifique”, deixando a opção bem abrangente às possibilidades do aluno.

$\mathrm{O}$ item "potencialidade em compreender fatos históricos e fatos que provavelmente ocorrerão no futuro; reconhecimento de personagens históricas e atuais da política ou reconhecimento de personagens da área artística" passou a ser intitulado como "potencialidade em compreender fatos históricos, atuais e futuros; reconhecimento de personagens históricas e atuais". Essa modificação permitiu que o item ficasse mais objetivo e amplo, pois foram retirados os termos personagens da política e da área artística, que restringiam a avaliação. Para ilustrar essa modificação, observa-se que o item avaliativo 
expresso na primeira versão "o aluno reconhece personagens atuais (da política ou atores) através de fotos ou desenhos?" passou a questionar na segunda versão "o aluno reconhece personagens atuais?". Além disso, foi incluída a sentença "entende fatos que estão ocorrendo atualmente?", pois, só eram questionados sobre a potencialidade de entender fatos do passado e do futuro, faltando a compreensão de fatos atuais.

$\mathrm{Na}$ área de conhecimentos matemáticos, houve uma primeira mudança na estruturação da tabela, da qual, em determinados lugares foram retiradas as variáveis "sim ou não", permitindo que o avaliador tivesse o acesso direto à coluna das habilidades. Isso foi necessário, porque as participantes escolhiam uma das variáveis (sim ou não) e depois não sabiam se era preciso especificar o nível de habilidade do aluno. Essa situação também foi observada por Delagracia (2007) no desenvolvimento do protocolo para avaliação de habilidades comunicativas. Nesse estudo, a autora trazia em seu instrumento uma tabela com a mesma estruturação do atual. E com a análise do preenchimento do instrumento, a autora observou que houve dúvidas em relação ao preenchimento dessa coluna, resultando em um grande número de respostas em branco. Além dessa readaptação na estrutura da tabela, houve a inserção dos comandos "sim e não" em baixo dos parênteses questionadores da terceira coluna, como segue o Quadro 17, com o exemplo da primeira versão:

\begin{tabular}{|c|c|c|c|c|c|}
\hline \multirow{2}{*}{\multicolumn{2}{|c|}{ Item avaliativo }} & \multirow[t]{2}{*}{ Itens avaliativos } & \multicolumn{2}{|c|}{$\begin{array}{c}\text { Precisa de objeto } \\
\text { concreto para realizar as } \\
\text { atividades? }\end{array}$} & \multirow{2}{*}{$\begin{array}{c}\text { Escreva as possíveis estratégias } \\
\text { que poderão ser realizadas para } \\
\text { melhorar essa habilidade do } \\
\text { aluno. }\end{array}$} \\
\hline & & & NÃO & SIM & \\
\hline \multirow{3}{*}{$\begin{array}{l}\text { 13.1) O aluno } \\
\text { reconhece } \\
\text { números? } \\
\text { Ex: Ele nomeia } \\
\text { corretamente os } \\
\text { números. }\end{array}$} & \multirow[b]{2}{*}{ ( ) SIM } & $\begin{array}{l}\text { ( ) Sim, reconhece os números indicados } \\
\text { para a série em que ele está. }\end{array}$ & () & () & \\
\hline & & $\begin{array}{l}\text { ( ) Sim, mas até o número específico. } \\
\text { Especifique: }\end{array}$ & () & () & \\
\hline & NÃO & Não preencher & \multicolumn{2}{|c|}{ Não preencher } & \\
\hline
\end{tabular}

Quadro 17 - Exemplo da Seção principal da primeira versão

Passando a ser, como segue no Quadro 18, na segunda versão:

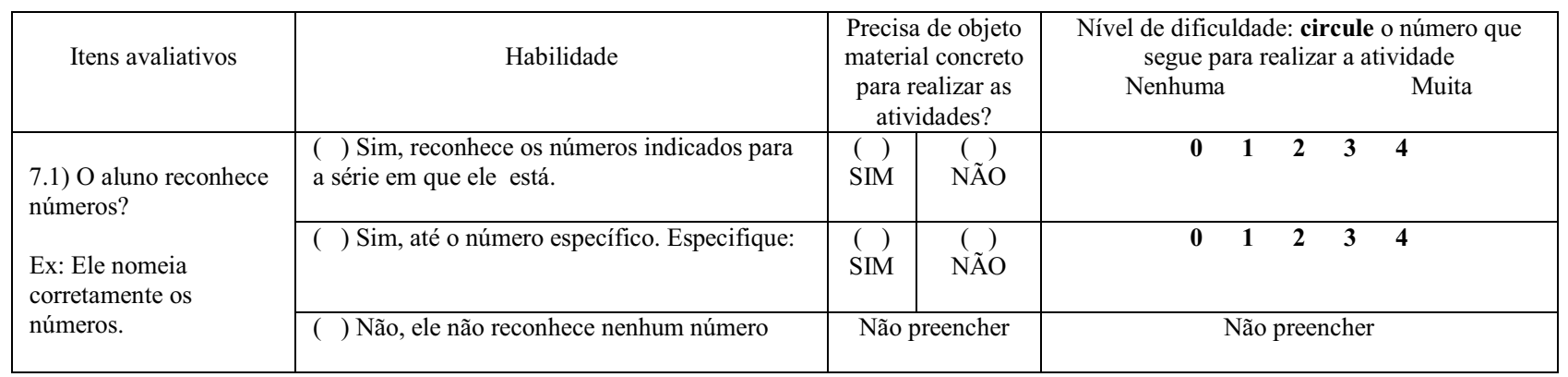

Quadro 18- Exemplo da Seção principal da segunda versão 
Além disso, na área "conhecimentos matemáticos" foi incluído um item avaliativo sobre a potencialidade do aluno em manipular calendário, e outro, sobre a potencialidade de fazer contas de multiplicação, que acabaram ficando de fora da primeira versão.

$\mathrm{Na}$ área "linguagem e comunicação", a estruturação da tabela, que na primeira versão continha quatro itens para avaliação, como podem ser observados no Quadro 19, foi reformulada em apenas um item avaliativo geral, e os outros itens foram acrescentados aos níveis de habilidades na segunda versão do instrumento, como podem ser observados no Quadro 20:

\begin{tabular}{|c|c|c|c|c|c|c|}
\hline \multicolumn{2}{|c|}{ Item para avaliação } & \multirow[t]{2}{*}{ Habilidade } & \multicolumn{3}{|c|}{ ELE TEM DIFICULDADE? } & \multirow{2}{*}{$\begin{array}{l}\text { Caso o aluno tenha } \\
\frac{\text { dificuldades, descreva-as }}{\text { em poucas palavras: }}\end{array}$} \\
\hline & & & Muita & Pouca & Nenhuma & \\
\hline \multirow{5}{*}{$\begin{array}{l}\text { 7.1) } \mathrm{O} \text { aluno } \\
\text { se comunica } \\
\text { com a fala } \\
\text { (linguagem } \\
\text { oral). }\end{array}$} & \multirow{5}{*}{ ( ) } & ( ) Fala oralmente, sem auxílio nenhum. & ( ) & ( ) & ( ) & \\
\hline & & $\begin{array}{l}\text { ( ) Fala, mas faz gestos para que seja } \\
\text { entendido. } \\
\text { Ex: Fala usando expressões faciais, gestos com } \\
\text { o uso das mãos. }\end{array}$ & ( ) & ( ) & ( ) & \\
\hline & & $\begin{array}{l}\text { ( ) Fala, mas tem ajuda de figuras para que } \\
\text { seja entendido. } \\
\text { Ex: Fala, mas usa a prancha de comunicação } \\
\text { alternativa para auxiliar. }\end{array}$ & ( ) & ( ) & ( ) & \\
\hline & & $\begin{array}{l}\text { ( ) Fala, mas usa vocalizadores. } \\
\text { Ex: Fala, mas precisa de aparelhos que } \\
\text { aumentem o som da fala. }\end{array}$ & ( ) & ( ) & ( ) & \\
\hline & & $\begin{array}{l}\text { ( ) Fala, mas utiliza outro tipo de auxílio para } \\
\text { se comunicar. Identifique: }\end{array}$ & ( ) & ( ) & ( ) & \\
\hline \multirow{7}{*}{$\begin{array}{l}\text { 7.2) } \mathrm{O} \text { aluno } \\
\text { não se } \\
\text { comunica com a } \\
\text { fala (linguagem } \\
\text { oral) }\end{array}$} & \multirow{7}{*}{ ( ) } & $\begin{array}{l}\text { ( ) O aluno utiliza figuras para comunicação. } \\
\text { Ex: Ele utiliza a prancha de comunicação } \\
\text { alternativa com figuras impressas. }\end{array}$ & ( ) & ( ) & ( ) & \\
\hline & & $\begin{array}{l}\text { ( ) O aluno utiliza fotos para a comunicação. } \\
\text { Ex. Ele não consegue interpretar figuras, por } \\
\text { isso, ele utiliza a prancha de comunicação } \\
\text { alternativa com fotos. }\end{array}$ & ( ) & ( ) & ( ) & \\
\hline & & $\begin{array}{l}\text { ( ) O aluno utiliza objetos para a } \\
\text { comunicação. } \\
\text { Ex: Ele não consegue interpretar figuras ou } \\
\text { fotos, por isso, ele precisa de objetos para se } \\
\text { comunicar, por exemplo, o uso de uma "maça" } \\
\text { de plástico para dizer "maça". }\end{array}$ & ( ) & ( ) & ( ) & \\
\hline & & $\begin{array}{l}\text { ( ) O aluno utiliza gestos para se comunicar. } \\
\text { Ex: Ele utiliza gestos manuais e corporais para } \\
\text { se comunicar, por exemplo, para dizer que } \\
\text { "gosta de alguma coisa" ele balança a cabeça } \\
\text { como sinal de "sim" ou faz o gesto com a mão. }\end{array}$ & ( ) & ( ) & ( ) & \\
\hline & & ( ) Utiliza Libras para se comunicar. & ( ) & ( ) & ( ) & \\
\hline & & $\begin{array}{l}\text { ( ) O aluno utiliza a mordida para a } \\
\text { comunicação. } \\
\text { Ex: O aluno não se comunica de outra } \\
\text { maneira, por isso, frequentemente ele morde } \\
\text { (os outros ou a si próprio) tentando se } \\
\text { comunicar. }\end{array}$ & ( ) & ( ) & ( ) & \\
\hline & & $\begin{array}{l}\text { ( ) O aluno utiliza expressões faciais para se } \\
\text { comunicar. } \\
\text { Ex: Ele "pisca os olhos com frequência", faz } \\
\text { "caretas", ou "mexe as sobrancelhas" para } \\
\text { indicar "sim ou não". }\end{array}$ & ( ) & ( ) & ( ) & \\
\hline
\end{tabular}




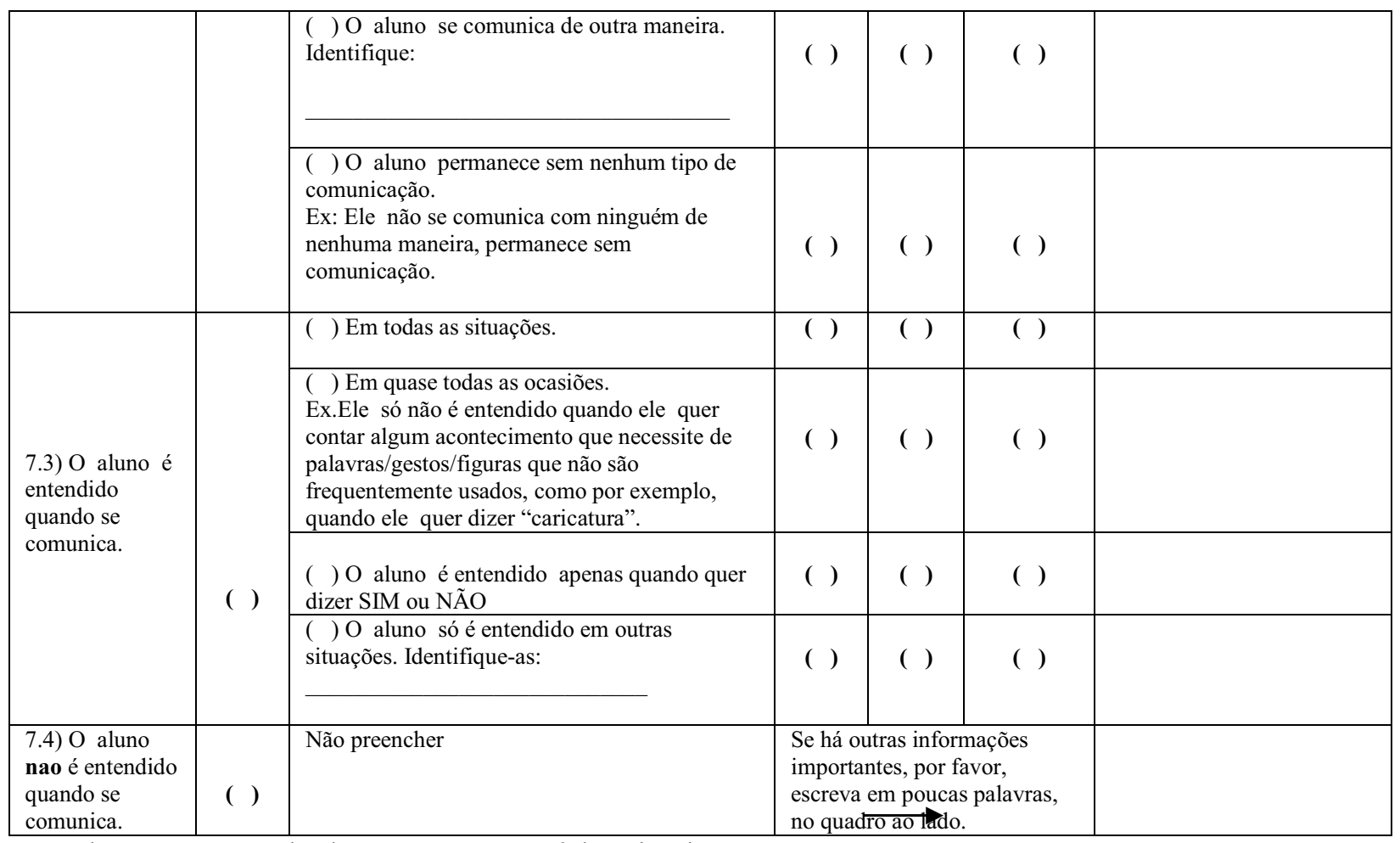

Quadro 19 - Exemplo da Seção principal da primeira versão

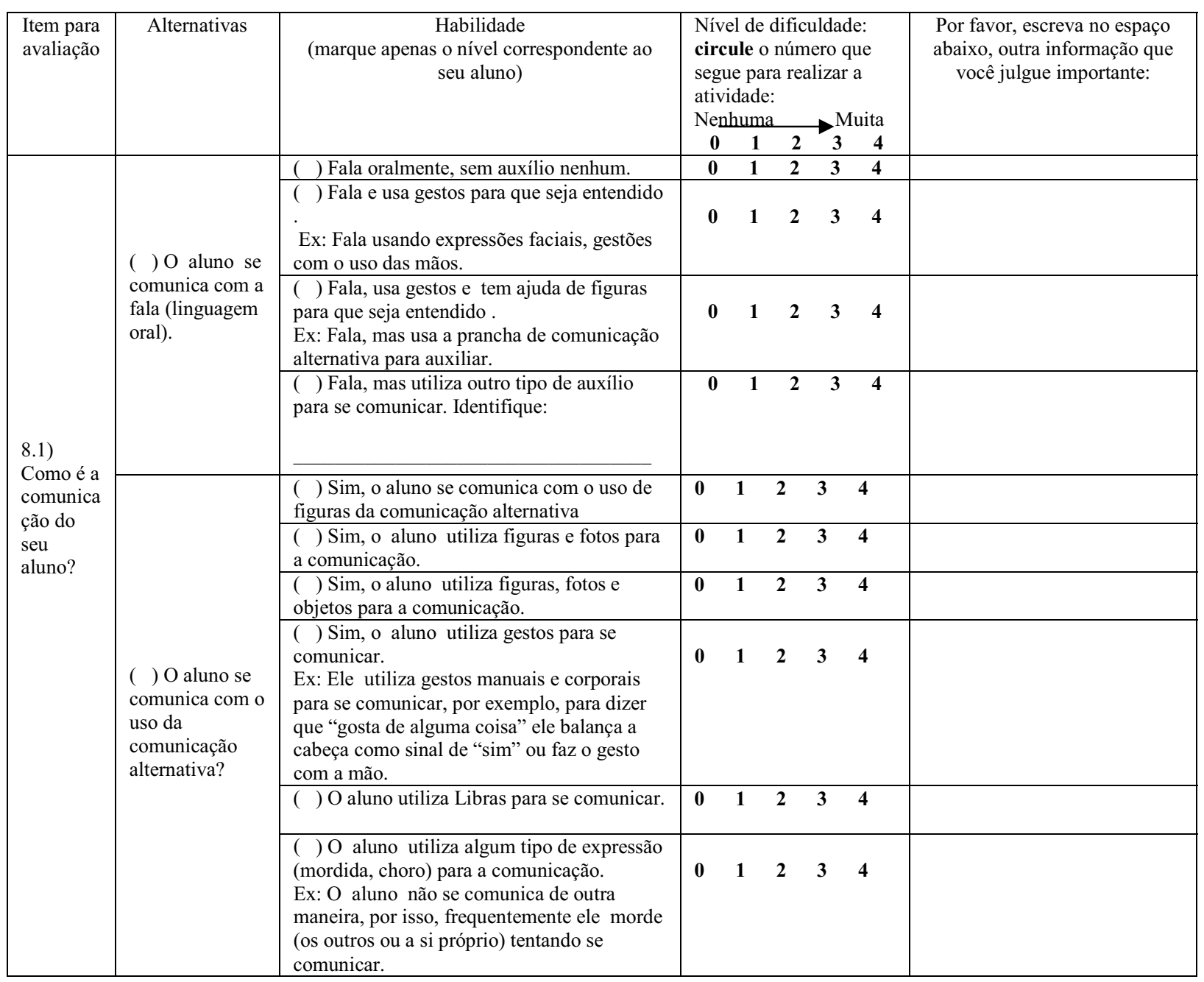




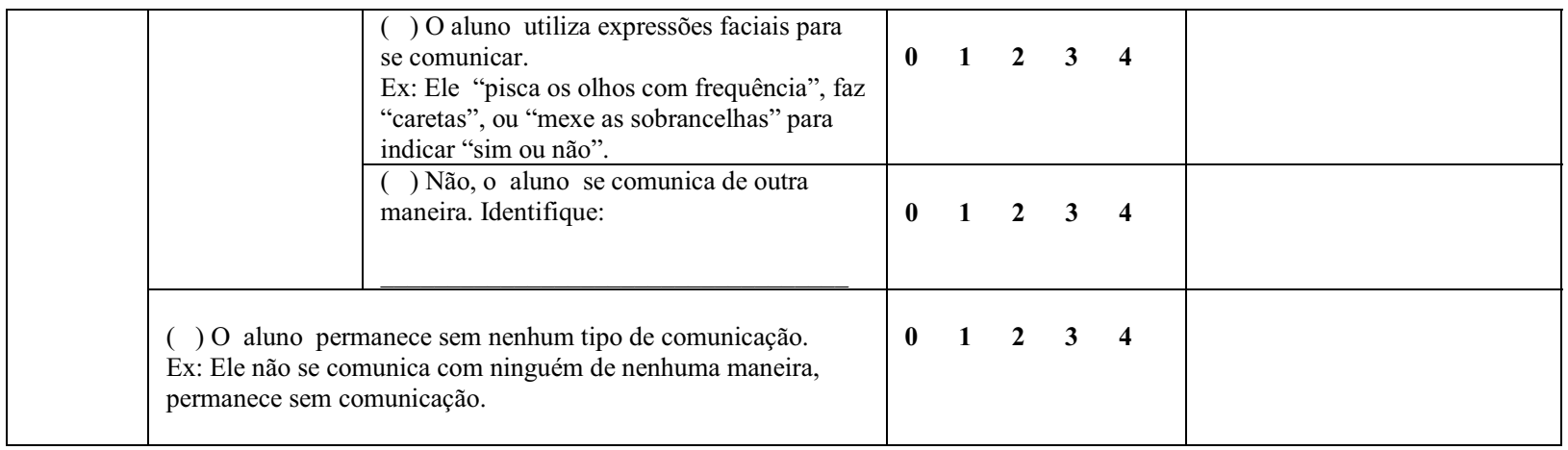

Quadro 20 - Exemplo da Seção principal da segunda versão

Em relação à dimensão das atividades pedagógicas, houve a necessidade de incluir uma tabela avaliativa que foi intitulada de "observações especificas sobre as atividades".

Essa tabela foi constituída por cinco itens avaliativos:

- O aluno realiza atividades referentes ao que está sendo trabalhado com o resto da sala?

- O aluno precisa de auxílio extra para concluir as atividades propostas para ele?

- O aluno precisa de um tempo maior para concluir a atividade?

- A atividade do aluno é compartilhada com o aprendizado da sala?

- O aluno conclui as atividades propostas para ele?

Dentre estes, o item "o aluno precisa de um tempo maior para concluir a atividade?", merece atenção, pois entende-se que o tempo disponibilizado para a realização das atividades aos alunos com paralisia cerebral é uma das estratégias fundamentais para garantir o seu aprendizado, já que, em muitos casos, essa realização é dificultada por um complexo quadro de limitações motoras (GODOI, 2001; MARTÍN; JÁUREGUI; LÓPEZ, 2004).

Em relação à tabela com o item "avaliação sobre o tipo de letra em atividades impressas", que era construída como se segue no Quadro 21, houve a retirada da coluna "ele tem dificuldade", pois essa pergunta discordava do objetivo da avaliação que era identificar o tipo de letra que facilita a visualização do aluno para a adaptação das atividades. A necessidade dessa tabela justifica-se por concordar com Taluse (2001) que salientou que, em alguns casos, a criança não realiza a atividade por não conseguir visualizá-la, já que há uma grande frequência de alterações oculares nessa população, e não por incapacidade cognitiva para realizar a atividade. Visando adequar ainda mais o material avaliativo, foram acrescentados exemplos de cores da letra em relação à cor do fundo, baseadas nas normas 
técnicas 9050 (BRASIL, 2004), que sugeriram determinadas cores de escrita combinadas com determinadas cores de fundo melhoram o contraste de estímulo gráfico. Porém, manteve-se na tabela um espaço para que o avaliador indicasse outro tipo de letra, outro tamanho e outro fundo que fosse mais indicado para o aluno, e que não eram contemplados pelos exemplos do instrumento. Observa-se no Quadro 22, a tabela da segunda versão após as modificações:

\begin{tabular}{|c|c|c|c|c|c|}
\hline & \multirow{2}{*}{$\begin{array}{l}\text { Tamanho da fonte em contraste } \\
\text { com a cor do fundo: }\end{array}$} & \multicolumn{3}{|c|}{ ELE TEM DIFICULDADE? } & \multirow[b]{2}{*}{$\begin{array}{l}\text { Por favor, escreva } \\
\text { no espaço abaixo, } \\
\text { outra informação } \\
\text { que você julgue } \\
\text { importante: }\end{array}$} \\
\hline & & $\begin{array}{r}\text { Muita } \\
\downarrow\end{array}$ & $\begin{array}{r}\text { Pouca } \\
\downarrow\end{array}$ & $\begin{array}{c}\text { Nenhuma } \\
\downarrow\end{array}$ & \\
\hline \multirow{4}{*}{$\begin{array}{l}\text { 6.1) Marque ao lado, } \\
\text { o tamanho da fonte, } \\
\text { e o contraste em } \\
\text { relação à escrita } \\
\text { com o fundo da } \\
\text { figura que é melhor } \\
\text { visualizada pelo seu } \\
\text { aluno. }\end{array}$} & 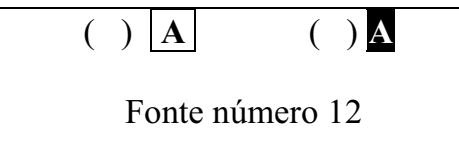 & ( ) & ( ) & ( ) & \\
\hline & $\begin{array}{l}\text { ( ) } \mathbf{A} \quad() \mathbf{A} \\
\text { Fonte número } 18\end{array}$ & $($ ) & ( ) & ( ) & \\
\hline & $\begin{array}{l}\text { ( ) } \mathbf{A} \quad(\text { ) } \mathbf{A} \\
\text { Fonte número } 26\end{array}$ & ( ) & ( ) & ( ) & \\
\hline & $\begin{array}{l}\text { ( ) } \mathbf{A} \quad(\text { ) } \mathbf{A} \\
\text { Fonte número } 48\end{array}$ & ( ) & ( ) & ( ) & \\
\hline & $\begin{array}{l}\text { Outra fonte. Especifique: } \\
\text { Tamanho da } \\
\text { fonte: } \\
\text { Cor da } \\
\text { escrita: } \\
\text { Cor do fundo: }\end{array}$ & ( ) & ( ) & ( ) & \\
\hline
\end{tabular}

Quadro 21 - Exemplo da Seção principal da primeira versão

\begin{tabular}{|l|l|l|l|}
\hline & \multicolumn{1}{|c|}{ Alternativas } & \multicolumn{2}{|c|}{ Contraste em relação à cor da letra e o fundo: } \\
\hline $\begin{array}{l}\text { 17.1) Marque ao lado, o } \\
\text { tamanho da fonte, e o } \\
\text { contraste em relação a } \\
\text { escrita com o fundo da } \\
\text { figura que deve ser } \\
\text { impressa para o aluno. }\end{array}$ & ( ) tamanho - 12 & $\begin{array}{l}\text { ( ) Letra preta } \\
\text { impressa na folha } \\
\text { branca }\end{array}$ & $\begin{array}{l}\text { ( ) Letra branca } \\
\text { impressas na folha } \\
\text { preta }\end{array}$ \\
\cline { 2 - 4 } $\begin{array}{l}\text { (marque a que é ideal } \\
\text { para o seu aluno) }\end{array}$ & ( ) tamanho-18 & $\begin{array}{l}\text { ( ) Letra verde } \\
\text { escuro impressa na } \\
\text { folha branca }\end{array}$ & $\begin{array}{l}\text { ( ) Letra amarela } \\
\text { impressa na folha } \\
\text { preta }\end{array}$ \\
\hline
\end{tabular}




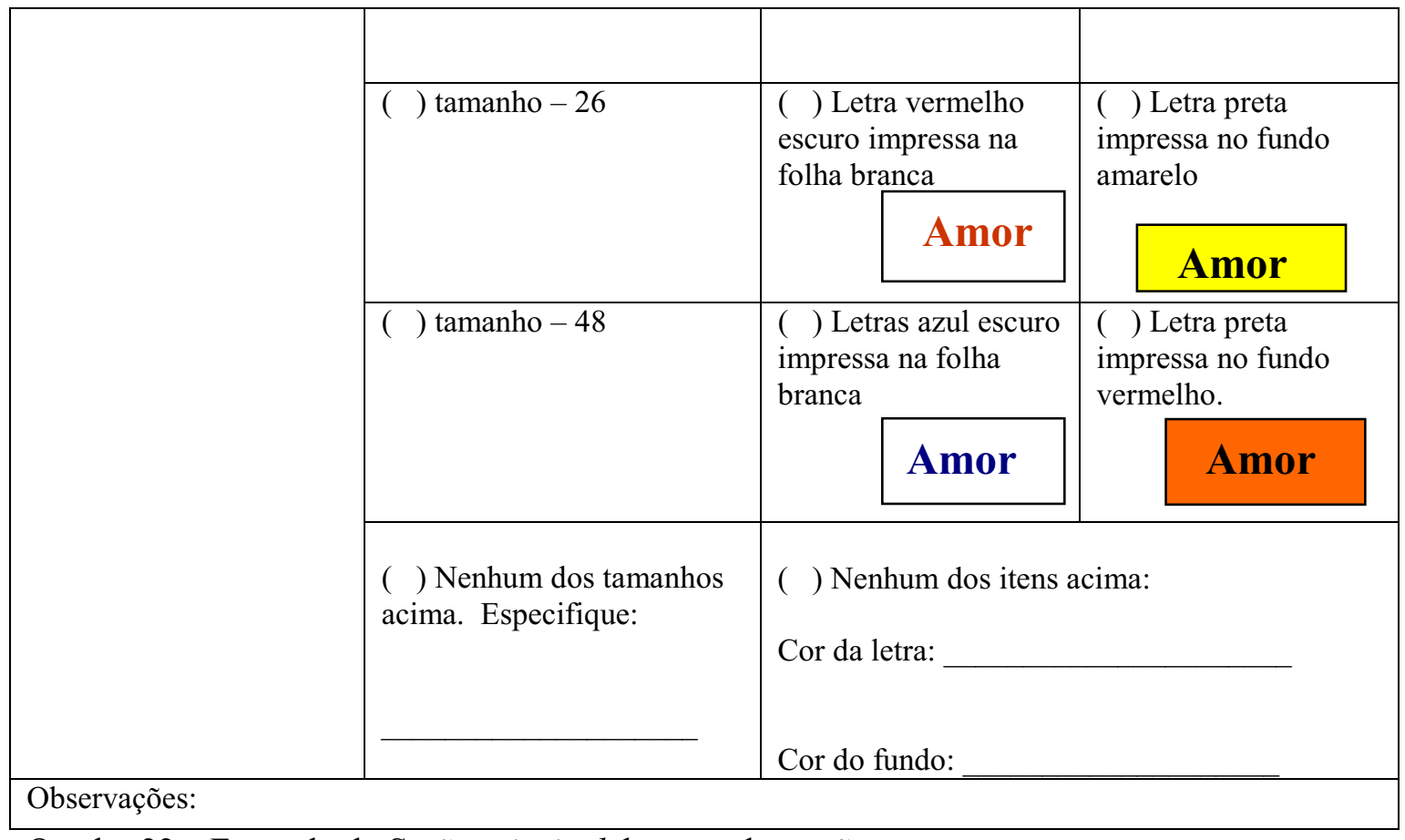

Quadro 22 - Exemplo da Seção principal da segunda versão

Na dimensão social, foi incluída no nível de habilidade a opção "sim, apenas com o professor" por sugestão das participantes, pois, elas alegaram que há situações em que a interação social acontece apenas entre professor e aluno, sem que outras pessoas do contexto escolar participem. Nessa mesma tabela, foi acrescentada à coluna que questionava sobre a frequência com que a ação acontecia, uma subcoluna com a opção "sempre" completando as duas já existentes "frequentemente e raramente". Ainda nessa área, na primeira versão, havia um item que questionava "se o aluno é respeitado pela turma quando ele está realizando atividade individualmente" e outro, que questionava se "ele é respeitado pela turma quando ele está realizando uma atividade coletivamente”. Essa divisão causou dúvidas sobre a avaliação desse item, pois as participantes não entenderam se era para responder se o aluno fazia ou não atividades sozinho e/ou em grupo. Real e Parker (2000) relataram que um dos problemas de ser realizar uma pergunta incompreensível é que as informações fornecidas pelo sujeito podem ser imprecisas. Para dificultar a interpretação desse item, o exemplo demonstrativo não era compatível com o que a sentença avaliava, como pode ser observado no Quadro 23:

\begin{tabular}{|l|l|l|l|}
\hline Item avaliativo & $\begin{array}{l}\text { Variávei } \\
\mathrm{s}\end{array}$ & Habilidade & $\begin{array}{c}\text { Por favor, escreva no espaço abaixo, outra informação } \\
\text { que você julgue importante: }\end{array}$ \\
\hline $\begin{array}{l}\text { 14.8) Ele é } \\
\text { respeitado pela }\end{array}$ & & ( ) Sim, por todos. & \\
\hline
\end{tabular}




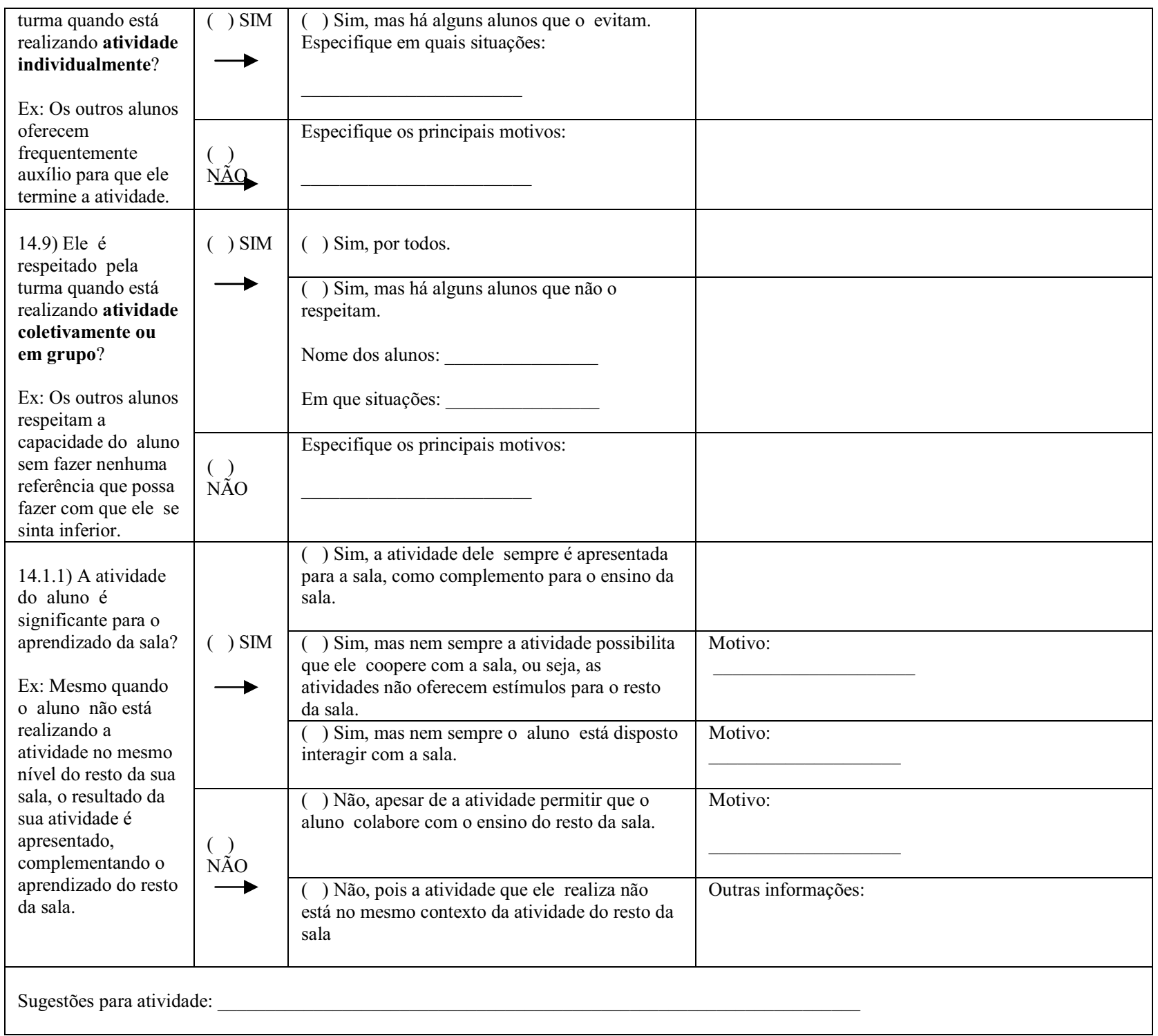

Quadro 23 - Exemplo da Seção principal da primeira versão

Assim, para um melhor entendimento sobre o objetivo da avaliação que era identificar se o aluno é respeitado em sala de aula, com o foco no social e não na sua potencialidade de realização da atividade, a sentença ficou: "Ele é respeitado pelos outros alunos na sala de aula?". Com esse item mais geral, a avaliação passou a não restringir uma situação especifica. Além disso, a última coluna onde havia um espaço para anotações adicionais foi mantida, caso o avaliador julgasse necessário pontuar outras situações que não eram contempladas no instrumento, como pode ser observado no Quadro 24:

\begin{tabular}{|l|l|l|}
\hline Item avaliativo & \multicolumn{1}{|c|}{ Itens avaliativos } & Escreva no espaço abaixo, outras informações: \\
\hline $\begin{array}{l}\text { 14.8) Ele é } \\
\text { respeitado pelos }\end{array}$ & $($ ) Sim, por todos. & \\
\hline
\end{tabular}




\begin{tabular}{|c|c|}
\hline $\begin{array}{l}\text { outros alunos na } \\
\text { sala de aula? }\end{array}$ & $\begin{array}{l}\text { ( ) Sim, mas há alunos que fazem brincadeiras } \\
\text { pejorativas em relação a ele. } \\
\text { Nome das crianças: }\end{array}$ \\
\hline $\begin{array}{l}\text { Ex: Os outros } \\
\text { alunos respeitam o } \\
\text { aluno sem fazer }\end{array}$ & Situações: \\
\hline inferiorizado. & $\begin{array}{l}\text { ( ) Sim, mas há alguns alunos que o evitam. } \\
\text { Nome: }\end{array}$ \\
\hline & Situações: \\
\hline
\end{tabular}

Quadro 24 - Exemplo da Seção principal da segunda versão

$\mathrm{Na}$ dimensão "motora: posicionamento", havia o item "que tipo de cadeira seu aluno utiliza" com o subitem "os pés do aluno ficam adequadamente apoiados no apoio, ou seja, deixando o ângulo do joelho em 90 graus?”, do qual foram retiradas as palavras “deixando o ângulo do joelho em 90 graus", pois, entende-se que para cada tipo de aluno é indicado um posicionamento adequado diferente.

A coluna intitulada "a cadeira possibilita uma posição estável para o aluno?", na primeira versão, era dividida em quatro linhas, sendo que cada linha continha três subcolunas, com três parênteses em cada, que ficavam dispostos para serem assinaladas em qualquer das opções: “totalmente, parcialmente ou nenhuma". Por sugestão das participantes, conclui-se que, essa grande quantidade de opção repetida com uma única possibilidade de escolha só gerava poluição visual e confundia o avaliador, como pode ser observado no Quadro 25:

\begin{tabular}{|c|c|c|c|c|c|c|c|}
\hline \multirow{2}{*}{$\begin{array}{l}\text { Itens para } \\
\text { avaliação }\end{array}$} & \multirow{2}{*}{$\begin{array}{l}\text { Níveis para } \\
\text { avaliação }\end{array}$} & \multirow{2}{*}{$\begin{array}{l}\text { Possui } \\
\text { apoio } \\
\text { para os } \\
\text { pés? }\end{array}$} & \multirow[t]{2}{*}{ Habilidade } & \multicolumn{3}{|c|}{$\begin{array}{c}\text { A cadeira possibilita uma posição } \\
\text { estável para o aluno ? }\end{array}$} & \multirow{2}{*}{$\begin{array}{l}\text { Por favor, escreva no espaço } \\
\text { abaixo, outra informação que } \\
\text { você julgue importante: }\end{array}$} \\
\hline & & & & $\begin{array}{l}\text { Totalment } \\
\mathrm{e}\end{array}$ & $\begin{array}{l}\text { Parcialment } \\
\text { e } \\
+\end{array}$ & $\begin{array}{l}\text { Nenhum } \\
\mathrm{a} \\
\downarrow\end{array}$ & \\
\hline \multirow{3}{*}{$\begin{array}{l}\text { 15.1) Que } \\
\text { tipo de } \\
\text { cadeira seu } \\
\text { aluno utiliza? }\end{array}$} & \multirow{3}{*}{$\begin{array}{l}\text { ( ) Cadeira } \\
\text { escolar } \\
\text { comum. } \\
\text { ( ) Cadeira de } \\
\text { rodas } \\
\text { ( ) Cadeira } \\
\text { adaptada. } \\
\text { Ex: cadeira } \\
\text { com encosto } \\
\text { adaptado para o } \\
\text { próprio aluno } \\
\text { ( ) Outro tipo }\end{array}$} & $\begin{array}{l}\text { ( ) } \\
\text { SIM }\end{array}$ & $\begin{array}{l}\text { ( ) Os pés do aluno } \\
\text { ficam adequadamente } \\
\text { apoiados no apoio, ou } \\
\text { seja, deixando o ângulo } \\
\text { do joelho em } 90^{\circ} \text {. }\end{array}$ & ( ) & ( ) & ( ) & 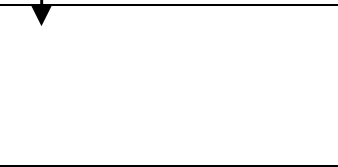 \\
\hline & & & $\begin{array}{l}\text { ( ) Os pés do aluno } \\
\text { não ficam } \\
\text { adequadamente } \\
\text { apoiados no apoio, ou } \\
\text { seja, contribui para uma } \\
\text { postura inadequada. }\end{array}$ & ( ) & ( ) & ( ) & \\
\hline & & $($ ) & $\begin{array}{l}\text { ( ) O aluno não } \\
\text { precisa de apoio nos } \\
\text { pés, pois ele tem } \\
\text { estabilidade. }\end{array}$ & ( ) & ( ) & ( ) & \\
\hline
\end{tabular}




\begin{tabular}{|l|l|l|l|l|l|l|}
\hline & $\begin{array}{l}\text { de cadeira. } \\
\text { Descreva, em } \\
\text { poucas } \\
\text { palavras, como } \\
\text { é essa cadeira: }\end{array}$ & NÃO & $\begin{array}{l}\text { ( ) O aluno precisa de } \\
\text { apoio, pois, sua postura } \\
\text { na cadeira é inadequada, } \\
\text { mas sua cadeira não } \\
\text { possui nenhum apoio } \\
\text { para pés. }\end{array}$ & ( ) & ( ) & ( ) \\
\hline
\end{tabular}

Quadro 25 - Exemplo da Seção principal da primeira versão

Dessa forma, as quatro linhas foram mescladas, formando apenas uma linha com as opções mencionadas citadas apenas uma vez, já que qualquer que fosse a situação do aluno, apenas um item avaliativo poderia ser assinalado, pois eles eram excludentes, como mostra o Quadro 26:

\begin{tabular}{|c|c|c|c|c|c|}
\hline $\begin{array}{l}\text { Itens para } \\
\text { avaliação }\end{array}$ & Níveis para avaliação & $\begin{array}{l}\text { Possui } \\
\text { apoio } \\
\text { para os } \\
\text { pés? }\end{array}$ & Habilidade & $\begin{array}{c}\text { A cadeira possibilita } \\
\text { uma posição } \\
\text { estável para o aluno? }\end{array}$ & $\begin{array}{l}\text { Escreva no espaço } \\
\text { abaixo, outra } \\
\text { informação que você } \\
\text { julgue importante: }\end{array}$ \\
\hline \multirow{4}{*}{$\begin{array}{l}\text { 15.1) Que } \\
\text { tipo de } \\
\text { cadeira seu } \\
\text { aluno } \\
\text { utiliza? }\end{array}$} & \multirow{3}{*}{$\begin{array}{l}\text { ( ) Cadeira escolar } \\
\text { comum. } \\
\text { ( ) Cadeira de rodas } \\
\text { ( ) Cadeira adaptada. } \\
\text { Ex: cadeira com encosto } \\
\text { adaptado para o próprio } \\
\text { aluno }\end{array}$} & \multirow{2}{*}{$\begin{array}{l}(\text { ) } \\
\text { SIM }\end{array}$} & $\begin{array}{l}\text { ( ) Os pés do aluno ficam } \\
\text { adequadamente apoiados no apoio. }\end{array}$ & \multirow{4}{*}{$\begin{array}{l}\text { ( ) TOTALMENTE } \\
\text { ( ) } \\
\text { PARCIALMENTE }\end{array}$} & \\
\hline & & & $\begin{array}{l}\text { ( ) Os pés do aluno não ficam } \\
\text { adequadamente apoiados no apoio, ou } \\
\text { seja, contribui para uma postura } \\
\text { inadequada. }\end{array}$ & & \\
\hline & & \multirow[b]{2}{*}{$\begin{array}{c}(\text { ) } \\
\mathrm{NÃO}\end{array}$} & $\begin{array}{l}\text { ( ) O aluno não precisa de apoio nos } \\
\text { pés, pois ele tem estabilidade. }\end{array}$ & & \\
\hline & $\begin{array}{l}\text { aluno } \\
\text { ( ) Outro tipo de } \\
\text { cadeira. } \\
\text { Descreva, em poucas } \\
\text { palavras, como é essa } \\
\text { cadeira: }\end{array}$ & & $\begin{array}{l}\text { ( ) O aluno precisa de apoio, pois, sua } \\
\text { postura na cadeira é inadequada, mas sua } \\
\text { cadeira não possui nenhum apoio para } \\
\text { pés. }\end{array}$ & & \\
\hline
\end{tabular}

Quadro 26 - Exemplo da Seção principal da primeira versão

$\mathrm{Na}$ dimensão "motora: material pedagógico”, o item avaliativo, que na primeira versão era "seu aluno manuseia lápis para realizar as atividades referentes à escrita?”, foi modificado para a segunda versão para "o aluno manuseia lápis para realizar as atividades". Essa modificação permitiu que o item tornasse mais abrangente, pois na primeira versão o item ficava restrito aos alunos que escreviam, o que não era tão relevante para essa avaliação, já que o objetivo principal era conhecer como era o manuseio e o tipo de lápis que o aluno utilizava, independente se era para pintar, para escrever ou para rabiscar.

Já no item que avaliava “o tamanho da borracha utilizada pelo aluno”, por sugestão das participantes, foi retirada a coluna que avaliava o tamanho da borracha, pois, de acordo com as participantes, quando o modelo da borracha é mencionado, o tamanho já fica implícito.

Na tabela sobre a avaliação da "utilização da régua", observada no Quadro 27, foi incluída uma coluna para questionar se a régua utilizada pelo aluno era normal ou adaptada, exemplificada no Quadro 28: 


\begin{tabular}{|c|c|c|c|}
\hline Itens para avaliação & $\begin{array}{l}\text { Variáve } \\
\text { is }\end{array}$ & Habilidade & $\begin{array}{l}\text { Caso o aluno tenha dificuldades, descreva-as em } \\
\text { poucas palavras: }\end{array}$ \\
\hline \multirow[t]{2}{*}{$\begin{array}{l}\text { 17.3) Seu aluno } \\
\text { manuseia régua? }\end{array}$} & $\begin{array}{l}(\text { ) } \\
\text { SIM }\end{array}$ & $\begin{array}{l}\text { ( ) Ele manuseia com muita dificuldade } \\
\text { ( ) Ele manuseia com pouca dificuldade } \\
\text { ( ) Ele manuseia com nenhuma dificuldade }\end{array}$ & \\
\hline & $\underset{\mathrm{NA} O}{()}$ & \multicolumn{2}{|c|}{ Por favor, escreva no espaço abaixo, outra informação que você julgue importante: } \\
\hline
\end{tabular}

Quadro 27 - Exemplo da Seção principal da primeira versão

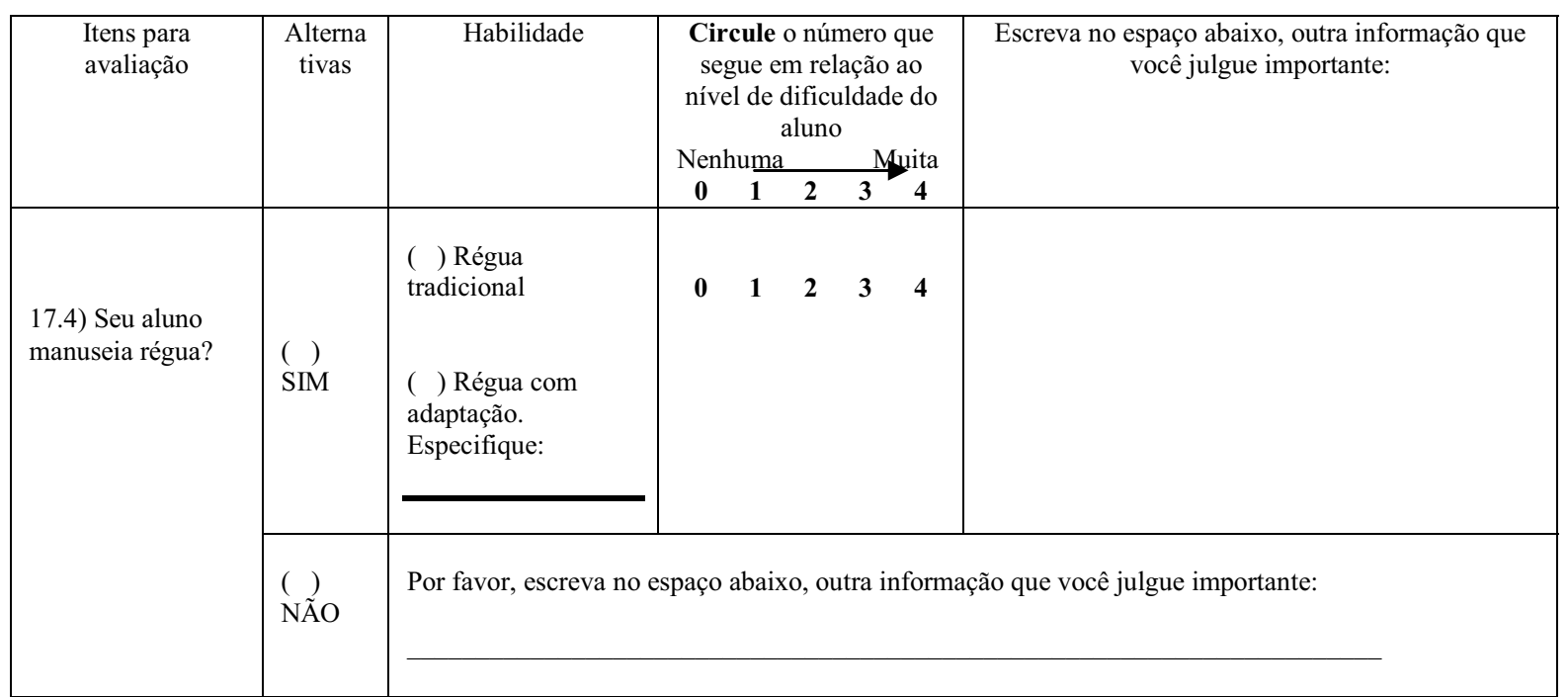

Quadro 28 - Exemplo da Seção principal da segunda versão

No item da primeira versão "seu aluno faz atividade no caderno", a coluna "caso o aluno tenha dificuldades, descreva-as em poucas palavras", como pode ser observado no Quadro 29, foi substituída pela coluna “o limite da pauta é respeitado?”, como pode ser observado no Quadro 30. Essa substituição foi necessária, pois as participantes relataram que os alunos têm o caderno com pauta, mas as pautas nem sempre são respeitadas. Dessa forma, apenas perguntar o tipo de caderno utilizado não trazia nenhuma informação que contribuiria para a adaptação do recurso.

\begin{tabular}{|c|c|c|c|c|c|c|}
\hline \multirow[b]{2}{*}{ Itens para avaliação } & \multirow[b]{2}{*}{ Variáveis } & \multirow{2}{*}{$\begin{array}{l}\text { Indique como são as pautas do } \\
\text { caderno: }\end{array}$} & \multicolumn{3}{|c|}{ ELE TEM DIFICULDADE? } & \multirow{2}{*}{$\begin{array}{l}\frac{\text { Caso o aluno tenha }}{\text { dificuldades }} \\
\text { descreva-as em poucas } \\
\text { palavras: }\end{array}$} \\
\hline & & & $\begin{array}{r}\text { Muita } \\
\downarrow \\
\downarrow\end{array}$ & Pouca & Nenhuma & \\
\hline & & $\begin{array}{l}\text { ( ) Com pautas simples, ou seja, com } \\
\text { linhas do caderno tradicional, sem } \\
\text { modificações. }\end{array}$ & ( ) & ( ) & ( ) & \\
\hline & & $\begin{array}{l}\text { ( ) Com pautas engrossadas, ou seja, } \\
\text { com as linhas mais grossas em relação } \\
\text { às linhas do caderno tradicional }\end{array}$ & ( ) & ( ) & ( ) & \\
\hline & $\longrightarrow$ & $\begin{array}{l}\text { ( ) Com pautas espaçadas, ou seja, } \\
\text { com um espaço maior entre as linhas } \\
\text { em relação às linhas do caderno } \\
\text { tradicional }\end{array}$ & ( ) & ( ) & ( ) & \\
\hline
\end{tabular}




\begin{tabular}{|l|l|l|l|l|l|l|}
\hline & $\begin{array}{l}\text { ( ) Com outro tipo de pauta. } \\
\text { Especifique: }\end{array}$ & ( ) & ( ) & ( ) & \\
& & & & & & \\
\hline
\end{tabular}

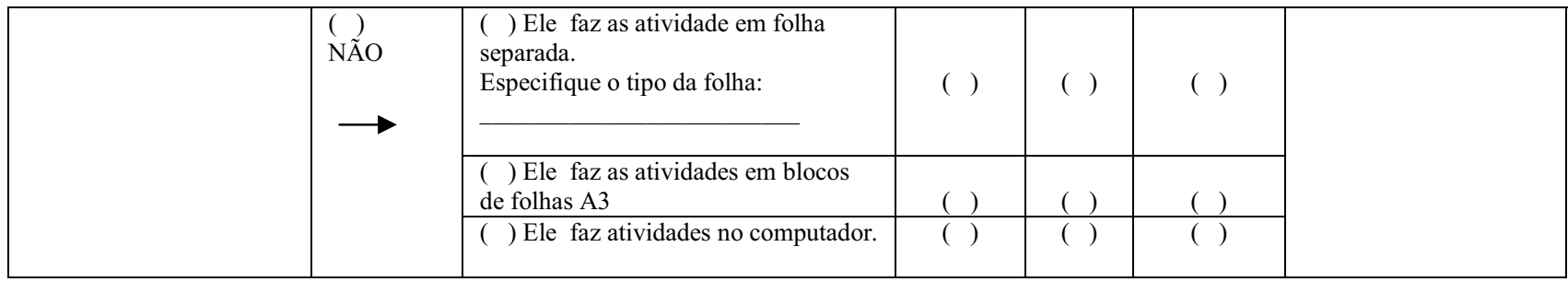

Quadro 29 - Exemplo da Seção principal da primeira versão

\begin{tabular}{|c|c|c|c|c|c|c|c|c|}
\hline $\begin{array}{l}\text { Itens para } \\
\text { avaliação }\end{array}$ & $\begin{array}{l}\text { Alternat } \\
\text { iva }\end{array}$ & Indique como são as pautas do caderno: & $\begin{array}{r}\text { Circul } \\
\text { relaçã } \\
\mathbf{0}\end{array}$ & & $\begin{array}{l}\text { erc } \\
\text { el } \\
\text { aly } \\
\text { ahu } \\
\text { lui } \\
\mathbf{2}\end{array}$ & a & $\begin{array}{l}\text { gue em } \\
\text { uldade } \\
4\end{array}$ & Outras informações: \\
\hline \multirow{7}{*}{$\begin{array}{l}\text { 18.1) Seu } \\
\text { aluno faz } \\
\text { atividades } \\
\text { no caderno? }\end{array}$} & \multirow{4}{*}{$\begin{array}{l}(\text { ) } \\
\text { SIM }\end{array}$} & $\begin{array}{l}\text { ( ) Com pautas simples, ou seja, com linhas do } \\
\text { caderno tradicional, sem modificações. }\end{array}$ & $\mathbf{0}$ & 1 & 2 & 3 & 4 & \multirow{4}{*}{$\begin{array}{l}\text { O limite da pauta é } \\
\text { respeitado? } \\
\text { ( ) Sim, ele consegue escrever } \\
\text { respeitando o limite das pautas } \\
\text { ( ) Sim, mas ele tem } \\
\text { dificuldade. } \\
\text { ( ) Não, sua escrita não } \\
\text { respeita os limites das pautas. }\end{array}$} \\
\hline & & $\begin{array}{l}\text { ( ) Com pautas engrossadas, ou seja, com as } \\
\text { linhas mais grossas em relação às linhas do } \\
\text { caderno tradicional: } \\
\text { Qual espessura: }\end{array}$ & $\mathbf{0}$ & 1 & 2 & 3 & 4 & \\
\hline & & $\begin{array}{l}\text { ( Com pautas espaçadas, ou seja, com um } \\
\text { espaço maior entre as linhas em relação às } \\
\text { linhas do caderno tradicional }\end{array}$ & $\mathbf{0}$ & 1 & 2 & 3 & 4 & \\
\hline & & $\begin{array}{l}\text { ( ) Com outro tipo de pauta. } \\
\text { Especifique: }\end{array}$ & $\mathbf{0}$ & 1 & 2 & 3 & 4 & \\
\hline & \multirow{3}{*}{$\stackrel{(~)}{\mathrm{NA} O}$} & $\begin{array}{l}\text { ( ) Ele faz as atividade em folha separada. } \\
\text { Especifique o tamanho da folha: }\end{array}$ & $\mathbf{0}$ & 1 & 2 & 3 & 4 & \multirow[t]{3}{*}{ Outras informações: } \\
\hline & & $\begin{array}{l}\text { A4 ( ) Carta ( ) Ofício ( ) Papel para } \\
\text { desenho } \\
\text { () Almaço. } \\
\text { Outra, especifique: }\end{array}$ & & & & & & \\
\hline & & ( ) Ele faz atividades no computador. & $\mathbf{0}$ & 1 & 2 & 3 & 4 & \\
\hline
\end{tabular}

Quadro 30 - Exemplo da Seção principal da segunda versão

O item da área "em relação ao movimento para indicar algo especifico" trazia a seguinte sentença: “como seu aluno indica para algo específico?”. O verbo "indicar” gerou insegurança e a principal pergunta feita pelas participantes foi: o verbo "indicar" quer dizer “apontar"? Manzini (2003) relatou que para escolher um vocabulário que garanta a compreensão de uma sentença é preciso que haja intimidade com a linguagem da população 
estudada. Em vista disso, o item foi modificado para a segunda versão para: "Como seu aluno aponta para indicar algo específico?".

Para a segunda versão, foi incluída uma tabela avaliativa sobre a descrição do posicionamento manual do aluno no momento da realização de atividades com o lápis ou com peças pequenas. A inclusão desse item foi importante para avaliar se, nos casos em que há um membro superior mais comprometido do que o outro, o aluno deixa de utilizá-lo e sobrecarrega o de melhor funcionamento. Esse item avaliativo já havia sido questionado no instrumento de preensão de Sankako, Oliveira e Manzini (2007, p. 150) como forma de uma única pergunta “Quando uma mão está manuseando o recurso a outra auxilia?”, porém, para o atual instrumento, o item foi incorporado à tabela com adaptações a sua escrita e com acréscimo de exemplos, como pode ser visto no Quadro 31:

\begin{tabular}{|l|l|l|}
\hline \multicolumn{1}{|c|}{ Item avaliativo } & \multicolumn{1}{|c|}{ Habilidade } & \multicolumn{1}{c|}{$\begin{array}{c}\text { Por favor, escreva no espaço abaixo, outra } \\
\text { informação que você julgue importante: }\end{array}$} \\
\hline \multirow{2}{*}{$\begin{array}{l}\text { 22.2) Função de auxílio das mãos ao } \\
\text { realizar as atividades }\end{array}$} & $\begin{array}{l}\text { ( ) Enquanto uma mão está realizando a atividade } \\
\text { a outra está auxiliando, como, por exemplo, } \\
\text { segurando o papel ou apoiada em cima da mesa . }\end{array}$ & $\begin{array}{l}\text { ( ) Enquanto uma mão está realizando a atividade } \\
\text { a outra está sem função, pois ele evita utilizar a } \\
\text { outra mão. }\end{array}$ \\
\hline
\end{tabular}

Quadro 31 - Exemplo da Seção principal da segunda versão

$\mathrm{Na}$ área "preferências individuais", houve a inclusão das seguintes questões para complementar a tabela: 1) qual o time de futebol favorito? 2) qual o personagem de desenho favorito? 3) qual o artista favorito? 4) qual a música favorita?

No item que avaliava o "posicionamento da cadeira do aluno em relação a sala", foi excluído o subitem “28.5) o aluno fica isolado da turma?”, pois conclui-se que essa informação deverá ser uma conclusão dos dados coletados com a avaliação. Além disso, esse tipo de pergunta pode influenciar o avaliador, já que é dado um modelo de comportamento que pode existir ou não no contexto da sala de aula. No momento da construção das perguntas é importante escolher as palavras e frases que não influenciem o sujeito, pois, caso haja palavras tendenciosas, essas poderão influenciar a resposta do sujeito ou ainda inibi-lo (REAL; PARKER, 2000; MANZINI, 2003).

No item que questionava sobre a estratégia utilizava, foi acrescentada uma breve explicação definindo o que seria estratégia de ensino e estratégia de avaliação, caso o avaliador não entendesse a diferença entre os dois termos utilizados, seguindo a definição de Manzini (no prelo, p.14): 
Estratégia para o ensino: nesse tipo de estratégia, o professor deve prever quais os estímulos podem ser apresentados ao aluno em diferentes momentos na realização da atividade. Por exemplo, nos momentos em que o aluno consegue fazer a tarefa com facilidade, com dificuldade ou nos momentos em que ele não consegue fazer a tarefa, além dos tipos de auxílio motor que podem ser acrescentados. Estratégia para a avaliação: o professor não fornece nenhum tipo de ajuda para que o aluno consiga realizar a atividade, pois, o professor deve observar e avaliar o que o aluno é capaz de fazer sem ajuda.

$\mathrm{Na}$ segunda versão do instrumento, como pode ser observado no Quadro 32, foi incluída uma tabela, que avalia os aspectos positivos da área emocional do aluno, visto que os itens da primeira versão do instrumento só avaliavam aspectos negativos, que contribuíam para a avaliação do aluno, mas não traçavam seu perfil. A inclusão dessa nova tabela atende aos preceitos de Souza (2004), que afirmou que os aspectos emocionais nos indivíduos com paralisia cerebral devem ser avaliados, para que, quando necessário, sofram intervenções para que o sujeito tenha perspectivas mais positivas de vida. $\mathrm{O}$ autor descreveu que, quando o quadro emocional do indivíduo é estável pode colaborar para a sua reabilitação, e para a sua interação social, proporcionando uma melhorar qualidade de vida. Dessa maneira, a nova tabela foi incluída, sendo os itens baseados nos instrumentos de avaliação de Bruno (2005), De Paula (2007) e Delagracia (2007).

\begin{tabular}{|c|c|c|c|c|c|}
\hline \multirow{3}{*}{$\begin{array}{l}\text { Item avaliativo } \\
\begin{array}{l}\text { 24.4) Marque ao } \\
\text { lado os aspectos } \\
\text { positivos do seu } \\
\text { aluno }\end{array}\end{array}$} & \multirow{2}{*}{$\begin{array}{l}\text { Habilidade } \\
\text { ( ) Alegre }\end{array}$} & \multicolumn{3}{|c|}{$\begin{array}{l}\text { COM QUE } \\
\text { FREQUÊNCIA? }\end{array}$} & \multirow[t]{2}{*}{$\begin{array}{l}\text { Por favor, escreva no espaço abaixo, outra informação } \\
\text { que você julgue importante: }\end{array}$} \\
\hline & & $\begin{array}{l}\text { ( ) } \\
\text { Nun } \\
\text { ca }\end{array}$ & $\begin{array}{c}\text { ( ) } \\
\text { Às } \\
\text { vezes }\end{array}$ & $\begin{array}{l}\text { ( ) } \\
\text { Sem } \\
\text { pre }\end{array}$ & \\
\hline & ( ) Atento & $\begin{array}{l}\text { ( ) } \\
\text { Nun } \\
\text { ca }\end{array}$ & $\begin{array}{c}\text { ( }) \\
\text { Às } \\
\text { vezes }\end{array}$ & $\begin{array}{l}\text { ( ) } \\
\text { Sem } \\
\text { pre }\end{array}$ & \\
\hline & ( ) Participativo & 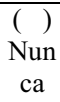 & $\begin{array}{c}\text { ( }) \\
\text { Às } \\
\text { vezes }\end{array}$ & $\begin{array}{l}\left(\begin{array}{r}) \\
\text { Sem } \\
\text { pre }\end{array}\right.\end{array}$ & \\
\hline & ( ) Brincalhão & $\begin{array}{c}\text { ( ) } \\
\text { Nun } \\
\text { ca }\end{array}$ & $\begin{array}{c}\text { ( }) \\
\text { Às } \\
\text { vezes }\end{array}$ & $\begin{array}{l}\text { ( ) } \\
\text { Sem } \\
\text { pre }\end{array}$ & \\
\hline & ( ) Interessado & $\begin{array}{l}\text { ( ) } \\
\text { Nun } \\
\text { ca }\end{array}$ & 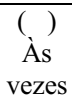 & $\begin{array}{l}\text { ( ) } \\
\text { Sem } \\
\text { pre }\end{array}$ & \\
\hline & ( ) Tem força de vontade & 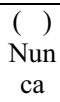 & 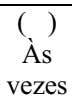 & $\begin{array}{l}\left(\begin{array}{l}) \\
\text { Sem } \\
\text { pre }\end{array}\right.\end{array}$ & \\
\hline
\end{tabular}

Quadro 32 - Exemplo da Seção principal da segunda versão

Foram, ainda, retiradas as palavras depreciativas dos itens avaliativos em todo o instrumento, como, por exemplo, as palavras “só, apenas, mas”, que deixavam os níveis de 
habilidade com cargas negativas, caso fosse compatível com o nível do aluno. Um exemplo disso é a resposta da pergunta "o aluno se comunica pela fala (linguagem oral)?” que era "Fala, mas faz gestos para que seja entendido". O uso do "mas" gerava a interpretação errônea de que usar gestos para complementar a fala era um déficit, quando, na realidade, é uma característica muito importante, que contribui para que o aluno seja entendido. Sobre esse assunto, Real e Parker (2000) alertaram para que as sentenças devem ser claras, simples e neutras para evitar que as palavras e frases tenham cargas emocionais que podem resultar em informações imprecisas ou ainda bloquear certas respostas.

Após essas modificações na primeira versão do instrumento, sua segunda versão foi elaborada. 


\section{APLICAÇ̃̃O DA SEGUNDA VERSÃO DO INSTRUMENTO}

A segunda versão do instrumento foi utilizada em dois momentos: 1) por seis alunas da Habilitação em Educação Especial e 2) pelos próprios pesquisadores na avaliação de uma aluna com paralisia cerebral matriculada no Ensino Fundamental.

\subsection{Aplicação da segunda versão do instrumento pelas participantes}

No dia 18 de março de 2009, a segunda versão do instrumento foi entregue às outras seis participantes. Naquela ocasião, a pesquisadora apresentou o instrumento, lendo as orientações gerais para preenchimento e os itens avaliativos, sem que nenhuma informação adicional fosse fornecida. Esse cuidado foi necessário, para não influenciá-las na interpretação e preenchimento do instrumento.

Após a entrega dos instrumentos, as participantes foram instruídas a avaliarem o aluno do estágio. Assim, naquele mesmo dia, uma nova data foi combinada para marcar uma reunião, na qual, as dúvidas e sugestões sobre a utilização do instrumento seriam discutidas.

A seguir, estão disponibilizadas no Quadro 33 informações a respeito das participantes que utilizaram a segunda versão do instrumento; e no Quadro 34, informações a respeito dos alunos avaliados pelas participantes.

Para garantir o sigilo das participantes e dos alunos avaliados, os nomes das participantes foram substituídos pelas iniciais P6, P7, P8, P9, P10 e P11, e os nomes dos alunos foram substituídos pelas iniciais A6, A7, A8, A9, A10 e A11. Dessa maneira, a P6 avaliou o aluno A6, a P7 avaliou o aluno A7, e assim, consecutivamente.

\begin{tabular}{|l|l|l|l|l|}
\hline Nome & Idade & $\begin{array}{l}\text { Conclusão } \\
\text { do curso } \\
\text { de } \\
\text { Pedagogia }\end{array}$ & \multicolumn{1}{|c|}{ Habilitações } & Outras informações: \\
\hline P6 & 28 & 2006 & $\begin{array}{l}\text { Habilitação em Educação Especial: } \\
\text { Deficiência Física, } \\
\text { Habilitação em administração e } \\
\text { supervisão escolar. }\end{array}$ & $\begin{array}{l}\text { Curso de magistério, } \\
\text { Leciona há 10 anos no } \\
\text { Ensino Fundamental. }\end{array}$ \\
\hline P7 & 28 & 2006 & $\begin{array}{l}\text { Habilitação em Educação Especial: } \\
\text { Deficiência Física, } \\
\text { Habilitação em administração e }\end{array}$ & $\begin{array}{l}\text { Curso de magistério, } \\
\text { Leciona há 10 anos no } \\
\text { Ensino Fundamental. }\end{array}$ \\
\hline
\end{tabular}




\begin{tabular}{|l|l|l|l|l|}
\hline & & & supervisão escolar. & \\
\hline P8 & 23 & 2006 & $\begin{array}{l}\text { Habilitação em administração e } \\
\text { supervisão, } \\
\text { Habilitação em Educação Especial: } \\
\text { Deficiência Física. }\end{array}$ & $\begin{array}{l}\text { Curso de magistério, } \\
\text { Leciona há 5 anos no } \\
\text { Ensino Fundamental, } \\
\text { Aluna do programa de } \\
\text { pós-graduação em } \\
\text { educação de Marília. }\end{array}$ \\
\hline P9 & 43 & 2004 & $\begin{array}{l}\text { Habilitação em Educação Especial: } \\
\text { Deficiência Física. }\end{array}$ & $\begin{array}{l}\text { Curso de magistério, } \\
\text { Aluna do curso de pós- } \\
\text { graduação: Educação } \\
\text { Especial e Inclusão. }\end{array}$ \\
\hline P10 & 31 & 2008 & $\begin{array}{l}\text { Habilitação em Educação Especial: } \\
\text { Deficiência Física }\end{array}$ & $\begin{array}{l}\text { Habilitação em Educação Especial: } \\
\text { Deficiência auditiva, deficiência } \\
\text { visual e deficiência física. }\end{array}$ \\
\hline P11 & 26 & 2005 & $\begin{array}{l}\text { É interprete de Libras } \\
\text { na rede estadual de } \\
\text { ensino. }\end{array}$ \\
\hline
\end{tabular}

Quadro 33 - Características das participantes da pesquisa

\begin{tabular}{|l|l|l|l|}
\hline NOME & \multicolumn{1}{|c|}{$\begin{array}{c}\text { Diagnóstico do aluno } \\
\text { avaliado }\end{array}$} & \multicolumn{1}{|c|}{$\begin{array}{c}\text { Idade do aluno } \\
\text { avaliado }\end{array}$} & \multicolumn{1}{c|}{ Informações: } \\
\hline A6 & $\begin{array}{l}\text { Paralisia Cerebral } \\
\text { (Tetraplégica) }\end{array}$ & 28 anos & Atendimento no CEES \\
\hline A7 & Mielomeningocele & 17 anos & Atendimento no CEES. \\
\hline A8 & $\begin{array}{l}\text { Atrofia cortical do lobo } \\
\text { frontal }\end{array}$ & 12 anos & $\begin{array}{l}\text { APAE; } \\
\text { Atendimento no CEES }\end{array}$ \\
\hline A9 & $\begin{array}{l}\text { Paralisia Cerebral } \\
\text { Espástica (Diplégico) }\end{array}$ & 8 anos & $\begin{array}{l}\text { Segundo ano do Ensino } \\
\text { Fundamental, } \\
\text { Atendimento no CEES }\end{array}$ \\
\hline A10 & $\begin{array}{l}\text { Síndrome de Hismith ML } \\
\text { Cort }\end{array}$ & 11 anos & $\begin{array}{l}\text { Quarta série do Ensino } \\
\text { Fundamental, } \\
\text { Atendimento no CEES. }\end{array}$ \\
\hline A11 & $\begin{array}{l}\text { Paralisia cerebral espástica } \\
\text { (Diplégica) }\end{array}$ & 17 anos & $\begin{array}{l}\text { Quinta série do ensino } \\
\text { fundamental. } \\
\text { E deficiente auditiva e está } \\
\text { iniciando na Libras. }\end{array}$ \\
\hline
\end{tabular}

Quadro 34- Características dos alunos avaliados com o uso da segunda versão do instrumento.

\subsubsection{Avaliação da segunda versão do instrumento pelas participantes}

No dia 17 de abril, reuniram-se as participantes e os pesquisadores para a análise da aplicação do instrumento, sendo que a pesquisadora anotou todas as informações no próprio instrumento. 
Cada participante relatou a sua avaliação. Dentre das onze participantes, apenas uma apontou uma dúvida em relação ao significado de uma palavra contido no instrumento, as outras disseram entender as dimensões avaliativas do instrumento.

No caso da participante P8, o instrumento utilizado na avaliação do aluno A8 ficou, na sua maior parte, em branco ou respondido negativamente (ou seja, a maioria das atividades avaliadas no instrumento não condizia com o nível de desenvolvimento do aluno). Essa situação foi devida à especificidade do quadro clínico do aluno, que não correspondia às habilidades esperadas para o Ensino Fundamental.

No caso da participante P6, com a avaliação da aluna A6, o instrumento ficou totalmente em branco ou respondido negativamente. Isso se deve ao fato de que a aluna não havia frequentado uma escola anteriormente, e o seu quadro clínico exigia prioridades que não eram compatíveis com as avaliadas no instrumento, como, por exemplo, auxílio para realizar atividades de vida diária e comunicação.

\subsection{Avaliação de uma aluna com paralisia cerebral matriculada no segundo ano do Ensino Fundamental}

Por ocasião da matrícula de uma aluna diagnosticada com paralisia cerebral no segundo ano do ensino fundamental (estrutura curricular de nove anos), dois profissionais com experiência em Educação Especial ${ }^{4}$ avaliaram a aluna com o uso do instrumento.

A avaliação da aluna teve inicio no dia 16 de junho de 2009. Nessa data, a sala da diretoria foi disponibilizada. Para essa avaliação, alguns materiais que estavam disponíveis no Laboratório de Educação Especial Prof. Ernani Vidon (UNESP- Marília) foram selecionados e levados para auxiliar na avaliação: 1) caderno de madeira com $40 \mathrm{~cm}$ de largura por $60 \mathrm{~cm}$ de comprimento, com canaletas coladas em uma placa de latão; 2) alfabeto em madeira imantado; 3) letras em E.V.A.; 4) lápis com engrossador emborrachado; 5) quebra-cabeça com duas, três e nove peças; 6) jogo das texturas; 7) cenas com sequência de um acontecimento com 3 cenas; 8) formas geométricas em E.V.A. medindo $4 \mathrm{~cm}$ de largura por $4 \mathrm{~cm}$ de comprimento; 9) ábaco em madeira, com base de $22 \mathrm{~cm}$ de comprimento, $8,5 \mathrm{~cm}$ de

\footnotetext{
${ }^{4}$ Sendo um Docente do Programa de Pós-graduação em Educação e do departamento de Educação Especial, e o outro, formado em pedagogia com Habilitação em deficiência física e aluna do programa de Pós-graduação em Educação, na linha de Educação Especial no Brasil.
} 
largura e 2,5 cm de altura; com peças com diâmetro de $4,5 \mathrm{~cm}$, com furo de $0,5 \mathrm{~cm} ; 10$ ) régua normal e régua em madeira com adaptação cilíndrica para a preensão; 11) foto, figura colorida, figura em preto e branco de um único objeto; 12) figura colorida e preto e branco de um conjunto de figuras; 13) revista; 14) suporte de madeira que permite inclinar verticalmente a atividade; 15) dominó em cores, feito em madeira, com $4 \mathrm{~cm}$ de comprimento, $9 \mathrm{~cm}$ de largura e $1 \mathrm{~cm}$ de espessura, sendo uma peça com duas cores e 16) calculadora falada em português.

Naquele dia, foi possível avaliar a aluna em relação à dimensão da leitura, escrita, matemática, posicionamento, discriminação de figuras, contexto emocional, linguagem e comunicação, dimensão social, dimensão motora, material pedagógico, área sensorial, dimensão emocional e dimensão do contexto familiar.

Observou-se que não foi necessário utilizar todos os materiais levados para auxiliar na avaliação, como, por exemplo:

- O jogo de cores não precisou ser utilizado, pois, no momento de interação entre o avaliador e a aluna, ela conseguiu descriminar as cores da blusa da coordenadora pedagógica sem dificuldade;

- A revista com fotos dos artistas de novelas, que auxiliaria na avaliação do reconhecimento de personagens atuais, foi desconsiderada pelo motivo de, anteriormente a avaliação, a aluna relatar que não assistia novelas;

- E ainda, materiais que não auxiliaram no desempenho da aluna: letras em EVA, que não facilitaram a visualização da letra, devido ao tamanho e às cores do material; figura colorida e em branco e preto de um conjunto de figuras, que, no caso, era a figura de uma cesta de frutas que, julgou-se que não era uma figura que permitia boa visualização, devido à qualidade da impressão do desenho.

A avaliação iniciou-se às 14 horas e terminou às 16 horas e 20 minutos com pausa de 20 minutos para o intervalo.

Devido ao tempo, e ao cansaço físico dos avaliadores e da aluna, julgou-se prudente marcar um segundo dia para avaliar alguns itens não realizados. Dessa maneira, marcou-se uma segunda avaliação para o dia 18 de junho de 2009, no entanto, nesse dia a professora precisou abonar, marcando uma nova data para o dia 22 de junho de 2009.

Novamente, no dia 22 houve um imprevisto, a aluna não compareceu à aula, sendo necessário remarcar a avaliação para o dia 23. 
Naquele dia foram levados os seguintes instrumentos: 1) alfabeto com as famílias silábicas em madeira, material já adaptado para a aluna específica, em virtude da necessidade avaliada anterior; 2) suporte de alumínio com pauta de barbante para a escrita; 3) tesoura com adaptação e 4) notebook, mouse convencional e software Mestre versão 1.0 (GOYOS; FREIRE, 1994).

Com a avaliação da aluna, foi possível identificar suas potencialidades e pontuar as áreas que necessitavam de intervenção; além disso, os dados contribuíram para direcionar a escolha da adaptação necessária para atender às necessidades da aluna.

\subsubsection{Dados da avaliação da aluna}

A avaliação da aluna e a sistematização dos dados confirmaram uma das características mais importantes do instrumento, que é buscar as potencialidades do aluno e as áreas que necessitam de intervenção.

Para melhor visualização, essas informações foram descritas seguindo as áreas avaliadas:

Características gerais da aluna: tem nove anos de idade e foi matriculada em 2009 no segundo ano do Ensino Fundamental (com estrutura curricular de nove anos). Anteriormente, havia frequentado a sala de deficiente físico em uma escola estadual da cidade, devido ao seu diagnóstico de paralisia cerebral - Diplégica.

Área interpretação de figuras fotos ou objetos: ao fornecer figuras correspondentes a uma história contada oralmente pela avaliadora, foi capaz de sequenciá-la sem dificuldade, e após a atividade, foi capaz de recontar a história. Identifica uma figura específica entre outras sem dificuldade e reconhece a figura de um desenho, seja no desenho em preto e branco, desenho colorido, miniatura ou objeto.

Área da leitura: conhece e sabe nomear todas as letras do alfabeto, em relação às famílias silábicas, no entanto, a aluna tende a ler as letras separadamente, mas, com ajuda verbal do mediador, a aluna leu as palavras (em letra maiúscula de forma): boi, queijo, Leda, papai, Zeza, pia, Xuxa.

Área da escrita: escreve com ajuda verbal do mediador, apresentando dois níveis de desempenho: 1) com o lápis e o caderno, precisa de mais ajuda verbal para escrever; 2) com a disposição das peças do alfabeto móvel, escreve mais rapidamente, pois, há o auxílio do 
material concreto no qual ela pode escolher entre as peças que procura e, ainda, a ajuda verbal do mediador.

Área da produção de frases: identifica palavras com rima e produz frases oralmente em diferentes tempos verbais.

Área da discriminação de figuras: discrimina uma figura específica dentre outras e sabe nomear as cores sem dificuldade.

Potencialidade em compreender fatos históricos, atuais e futuros: entende fatos, relatos em qualquer tempo verbal.

Conhecimento matemático: reconhece a sequência dos números com o auxílio do material concreto até o número nove; reconhece formas geométricas e faz contas de adição e subtração indicadas para a sua série. Em relação às outras habilidades, como, por exemplo, divisão, multiplicação e uso da calculadora, constatou-se que, essas habilidades ainda não eram objetivos da série em que estava matriculada, por isso, não faziam parte do seu domínio.

Área da linguagem e comunicação: fala oralmente sem dificuldade e por isso, é entendida em qualquer situação; entende ordens simples e complexas; faz troca de turno (mantém um diálogo); inicia uma conversa; relata fatos pessoais em diferentes tempos verbais; relata acontecimentos com terceiros em diferentes tempos verbais.

Área acadêmica: faz as mesmas atividades do resto da sala, mas com ajuda dos outros alunos.

Atividades impressas: em relação a atividades impressas, visualiza as atividades, mas, tem mais facilidade quando elas são apresentadas em um fundo que contrasta com as figuras. Outra característica observada, é que a aluna visualiza as figuras com maior facilidade, quando são apresentadas na posição vertical.

Área social: interage bem com as pessoas, inclusive com os alunos e com a sua professora; respeita as regras da sala e é respeitada pela turma.

Área motora: posicionamento: a cadeira e a mesa da aluna foram avaliadas anteriormente e adaptadas de acordo com as suas necessidades.

Área motora: material pedagógico: escreve com um lápis com a espessura mais grossa, mas tem dificuldades para realizar os movimentos da escrita; em relação ao uso da borracha, ela não apresenta nenhuma dificuldade em manuseá-la. Em relação ao caderno, a coordenadora pedagógica já havia adaptado um caderno com pautas ampliadas com espessura $1,5 \mathrm{~cm}$, com a avaliação, constatou-se que esse caderno adaptado favorecia o aprendizado e estava de acordo com suas necessidades. Em relação aos movimentos para acionar o mouse do computador foi avaliado que a aluna fazia dois movimentos, o primeiro de manusear o 
mouse para posicionar o cursor no lugar desejado, e o segundo, após esse movimento, a aluna soltava o mouse e fazia o movimento com o dedo indicador para acioná-lo; no entanto, com a instrução verbal do avaliador, indicando que a aluna deveria segurar o mouse, posicionar o cursor, continuar segurando o mouse, e, ao mesmo tempo, sem soltar o mouse, ela deveria pressioná-lo com o dedo indicador, a aluna começou a fazer o movimento com mais precisão, contudo, ela precisou ser sempre lembrada. Em relação ao uso da mão não dominante, a aluna usa esse membro para auxiliar o outro, desde que ela seja lembrada pela mediadora.

Área sensorial: discrimina todo o tipo de superfície e discrimina som e olfato sem dificuldade.

Área emocional: é alegre, comunicativa, não adota comportamento de autoestimulação, não é agressiva, não se distrai facilmente, é atenta, participativa, interessada e tem muita força de vontade para realizar as atividades e interagir socialmente com os outros alunos.

Localização do aluno na sala: a aluna senta na primeira carteira de frente à lousa, o que facilita a sua visualização.

Estratégias de ensino: a professora usa como estratégia deixar a aluna sentar com outro aluno para auxiliá-la nas atividades, todo dia há um rodízio de aluno, o que contribui para a sua aprendizagem, para a interação social entre ela e os outros alunos, e facilita o trabalho da professora.

\subsection{2 Áreas que necessitam de intervenção e sugestões de estratégias para a aluna avaliada.}

Aproveitando o clima favorável da sala, o interesse e o envolvimento profissional da professora e da coordenadora pedagógica, que se mostraram interessadas e comprometidas com a aprendizagem da aluna, e relacionam esses fatores com a avaliação da aluna foi sugerido:

- Continuar trabalhando em grupo, pois, o trabalho em grupo favorece a interação social, e pelas características da aluna, o trabalho em grupo é estimulante para ela. No entanto, observar se os ajudantes não excedem no auxílio, fazendo as atividades por ela. 
- Em relação à posição da atividade na mesa, o posicionamento vertical contribui para o posicionamento adequado da aluna, favorecendo a postura do pescoço e facilitando a sua visualização, principalmente, em atividades de leitura. Essa posição pode ser conseguida com o auxílio de um suporte em cima da mesa da aluna.

- Trabalhar com atividades que apresentem as famílias silábicas e não as letras isoladas do alfabeto, para potencializar o que a aluna já sabe.

- Em relação à atividade de quebra-cabeça, sugere-se que comece a ser trabalhado com um objeto concreto em que falte uma parte, para que a aluna monte, em seguida, gradualmente, o material deve ser substituído por foto, e depois por figura, como, por exemplo, uma figura conhecida pela aluna. Nas primeiras tentativas da aluna, a figura precisa ser simples, sem muitos detalhes, apresentando contraste em relação à figura e ao fundo, além disso, o modelo inteiro deve permanecer na mesa, sendo retirado quando ela mostrar independência para realizar a atividade. Devem ser fornecidas dicas verbais e ajuda física quando necessárias.

- Em relação à produção de texto, a aluna tem facilidade em comunicar-se, por isso, deve ser estimulada a produzir textos oralmente, enquanto adquire a escrita.

- Em relação aos conhecimentos matemáticos, a aluna sabe sequenciar, mas apresentou dificuldades para encontrar a correspondência gráfica do número, mesmo com o uso do material concreto. Assim, sugerem-se atividades com materiais concretos, que podem ser planejadas em situação de jogos, aproveitando a facilidade de interação da aluna com os outros alunos.

- Em relação ao uso do computador, duas estratégias são sugeridas: 1) instrução verbal para instrução do movimento do manuseio correto do mouse, quando necessário, sendo gradualmente retirada; 2) retirada de estímulos-surpresa para evitar a liberação de espasmos crônicos extensores, como, por exemplo, músicas para indicar que a tarefa foi concluída. Caso esse tipo de estímulo seja necessário, explicar para a criança toda a atividade anteriormente, inclusive, demonstrando o estímulo, para evitar o elemento surpresa. 
- Materiais pedagógicos, a régua e a tesoura convencional não facilitam o manuseio da aluna, necessitando ser adaptadas para a sua utilização.

- Em relação ao uso da mão não dominante, a aluna precisa ser lembrada para que a utilize como auxílio nos movimentos da mão dominante.

A partir da avaliação da aluna, determinados materiais adaptados foram sugeridos:

1. Régua com apoiador circular para facilitar a preensão da aluna;

2. Tesoura adaptada, permitindo que o movimento seja feito com a mão em pronação;

3. Adaptação de quebra-cabeça com fotos e figuras da preferência da aluna;

4. Material concreto com as famílias silábicas e suporte de alumínio com separador de barbante para escrita.

A avaliação da aluna contribuiu para que novas modificações fossem feitas para a construção da terceira versão do instrumento, para facilitar o seu uso e a compreensão das áreas avaliativas. 


\section{CONSTRUÇÃO DA TERCEIRA VERSÃO DO INSTRUMENTO}

A partir da análise do uso da segunda versão do instrumento pelas participantes na avaliação de seus alunos do estágio, e pelos próprios pesquisadores na avaliação de uma aluna com o diagnóstico de paralisia cerebral matriculada no Ensino Fundamental, a terceira versão do instrumento foi elaborada.

\subsection{Contribuições das participantes para a construção da terceira versão do instrumento}

Com as análises das participantes sobre o uso do instrumento, foi possível realizar novas mudanças que contribuíram para a formulação da terceira versão do instrumento, em relação à substituição de palavras com dois significados, como, por exemplo, quando uma participante revelou que ficou confusa com a palavra "brincalhão" apresentada na área intitulada "características emocionais do aluno". Essa palavra era uma das opções de resposta do item que questionava os aspectos positivos do aluno. Na interpretação da participante, a palavra "brincalhão" teria dois significados: 1) brincalhão no sentido de brincar com brinquedos e 2) brincalhão no sentido de fazer brincadeiras verbais. Concordando com Bunchaft e Cavas (2002) quando alertaram que é preciso evitar termos genéricos para não causar confusão na interpretação dos itens, optou-se por retirá-la e inserir um espaço em branco para que possibilitasse ao avaliador anotar, quando necessário, outras características positivas da criança.

\subsection{Contribuições dos pesquisadores para a construção da terceira versão do instrumento}

Com a análise da avaliação da aluna com o uso da segunda versão do instrumento, foi possível realizar novas mudanças que contribuíram para a formulação da terceira versão do instrumento, em relação à:

- Acréscimo de novas áreas de avaliação e aperfeiçoamento das existentes;

- Mudança na parte estrutural do instrumento;

- Ilustração de itens de avaliação; 
- Divisão do instrumento em quatro partes: Parte I: avaliação do aluno: contexto individual; Parte II: avaliação do aluno: contexto social; Parte III: resumo da avaliação e Parte IV: categorias para a adaptação ou confecção do recurso.

Em relação à coluna "circule o número que segue em relação ao nível de dificuldade do aluno”, julgou-se necessário acrescentá-la nas áreas de habilidade que não a possuíam, como, por exemplo, na área "habilidade em relação à interpretação de figuras, fotos ou objetos" em que houve a substituição da última coluna para adequação desta, como pode ser observado no Quadro 35, na segunda versão do instrumento, e no Quadro 36, na terceira versão do instrumento:

\begin{tabular}{|c|c|c|}
\hline Itens para avaliação & $\begin{array}{c}\text { Habilidade } \\
\text { (marque apenas o nível correspondente ao seu aluno) }\end{array}$ & $\begin{array}{l}\text { Escreva no espaço abaixo outra } \\
\text { informação que você julgue necessárias: }\end{array}$ \\
\hline \multirow{5}{*}{$\begin{array}{l}\text { 1.2)O aluno identifica uma figura específica } \\
\text { entre outras figuras? } \\
\text { Ex: Quando é apresentada uma figura com } \\
\text { diversos detalhes, como, por exemplo, uma } \\
\text { cesta de frutas, ele identifica, a partir da } \\
\text { pergunta do avaliador: onde está a maçã? }\end{array}$} & $\begin{array}{l}\text { ( ) Sim, ele não tem dificuldade para realizar essa } \\
\text { atividade. }\end{array}$ & \\
\hline & $\begin{array}{l}\text { ( ) Sim, ele precisa trabalhar com fotos de cenas reais, } \\
\text { pois não reconhece desenhos. }\end{array}$ & \\
\hline & $\begin{array}{l}\text { ( ) Sim, ele precisa trabalhar com fotos, e com auxílio } \\
\text { de objetos em miniatura de cenas reais. }\end{array}$ & \\
\hline & $\begin{array}{l}\text { ( ) Sim, ele precisa trabalhar com fotos, e com auxílio } \\
\text { de objetos em tamanho que representem o real. }\end{array}$ & \\
\hline & ( ) Não, ele não faz essa atividade. & \\
\hline
\end{tabular}

Quadro 35 - Exemplo da Seção principal da segunda versão

\begin{tabular}{|c|c|c|c|c|c|c|}
\hline Itens para avaliação & $\begin{array}{c}\text { Habilidade } \\
\text { (marque apenas o nível correspondente ao seu aluno) }\end{array}$ & \multicolumn{5}{|c|}{$\begin{array}{l}\text { Circule o número correspondente ao nível } \\
\text { de dificuldade para realizar a atividade } \\
\text { Nenhuma }\end{array}$} \\
\hline \multirow{5}{*}{$\begin{array}{l}\text { 1.2)O aluno identifica uma figura } \\
\text { específica entre outras figuras? } \\
\text { Ex: Quando é apresentada uma } \\
\text { figura com diversos detalhes, } \\
\text { como, por exemplo, uma cesta de } \\
\text { frutas, ele identifica, a partir da } \\
\text { pergunta do avaliador: onde está a } \\
\text { maçã? }\end{array}$} & ( ) Sim, ele não tem dificuldade para realizar essa atividade. & \multirow{5}{*}{$\mathbf{0}$} & \multirow{5}{*}{1} & \multirow{5}{*}{2} & \multirow{5}{*}{3} & \multirow{5}{*}{4} \\
\hline & $\begin{array}{l}\text { ( ) Sim, ele precisa trabalhar com fotos de cenas reais, pois ele } \\
\text { não reconhece desenhos. }\end{array}$ & & & & & \\
\hline & $\begin{array}{l}\text { ( ) Sim, ele precisa trabalhar com objetos em miniatura de } \\
\text { cenas reais. }\end{array}$ & & & & & \\
\hline & $\begin{array}{l}\text { ( ) Sim, ele precisa trabalhar com objetos em tamanho que } \\
\text { representem o real. }\end{array}$ & & & & & \\
\hline & ( ) Não, ele não faz essa atividade. & & & & & \\
\hline
\end{tabular}

Quadro 36 - Exemplo da Seção principal da terceira versão

Observa-se ainda, no Quadro 35, que algumas respostas do nível de habilidade traziam como sugestão o uso de mais de um objeto para a realização da ação questionada, como, por exemplo, o uso de fotos e objetos em miniatura. Constatou-se que esse tipo de resposta não era viável, pois, o uso de objetos de diferente natureza pode confundir o aluno, ao invés de colaborar para a sua aprendizagem, por isso, foi retirada. 
$\mathrm{Na}$ área "habilidades em relação à leitura: material pedagógico" foram acrescentados três itens avaliativos no nível de habilidade: 1) Ele lê as famílias silábicas; 2) Ele reconhece o alfabeto e 3) Ele reconhece as vogais, ampliando as possibilidades avaliativas dessa área.

Na área "habilidades em relação à escrita", optou por retirar o exemplo do nível de habilidade que continha a palavra "apenas", a qual se torna depreciativa. Essa mudança já havia sido feita para a construção da segunda versão, no entanto, nota-se que, este exemplo específico passou despercebido na reformulação do instrumento.

$\mathrm{Na}$ área "conhecimentos matemáticos", optou-se pela reestruturação dos itens avaliativos, que estavam dispostos na segunda versão: 7.1) reconhece números?; 7.2) o aluno sequencia os números?; 7.3) reconhece formas geométrica?; 7.4) o aluno faz correspondência entre a quantidade de objetos com a representação em números? 7.5) o aluno utiliza calculadora?; 7.6) sabe manusear o calendário?; 7.7) o aluno faz contas de adição?; 7.8) o aluno faz contas de subtração?; 7.9) faz contas de divisão?; 7.1.0) o aluno faz contas de multiplicação? Essa sequência dificultava a avaliação, por não estar de acordo com a estruturação do instrumento que tem o intuito de começar das habilidades gerais, seguindo para as específicas, ou seja, o item 7.1 não estava em um lugar adequado, por isso, para a terceira versão do instrumento essa área passou a ter a seguinte sequência: 7.1) faz contas de adição?; 7.2) faz contas de subtração?; 7.3) o aluno faz contas de multiplicação?; 7.4) o aluno faz contas de divisão?; 7.5) o aluno sequencia os números?; 7.6) o aluno faz correspondência entre a quantidade de objetos com a representação em números? 7.7) o aluno reconhece números?; 7.8) o aluno utiliza calculadora?; 7.9) o aluno reconhece formas geométrica?; 7.1.0) o aluno sabe manusear o calendário?. Além disso, os níveis de habilidades sobre a realização de contas de adição, subtração, multiplicação e divisão que na primeira versão, traziam a resposta afirmativa "sim, faz as contas de ...", foi acrescentado "sim, faz as contas de ... , indicadas para sua série". Acredita-se que, o acréscimo dessa informação foi relevante, pois, em alguns casos, a avaliação poderia sugerir que a não realização da atividade seria um déficit do aluno, quando na verdade, a habilidade não estava compatível com o nível de ensino do aluno.

$\mathrm{Na}$ "área motora: posicionamento”, acrescentou-se ao item de avaliação a opção "a cadeira possui faixa para o posicionamento dos pés", que não constava na segunda versão.

$\mathrm{Na}$ “área motora: material pedagógico", acrescentou-se na terceira versão do instrumento o item para avaliar as possibilidades do manuseio da tesoura e adequou-se à formatação da coluna, possibilitando a anotação de observações sobre adaptações 
anteriormente feitas nesses materiais, como pode ser observado no Quadro 37 e no Quadro 38:

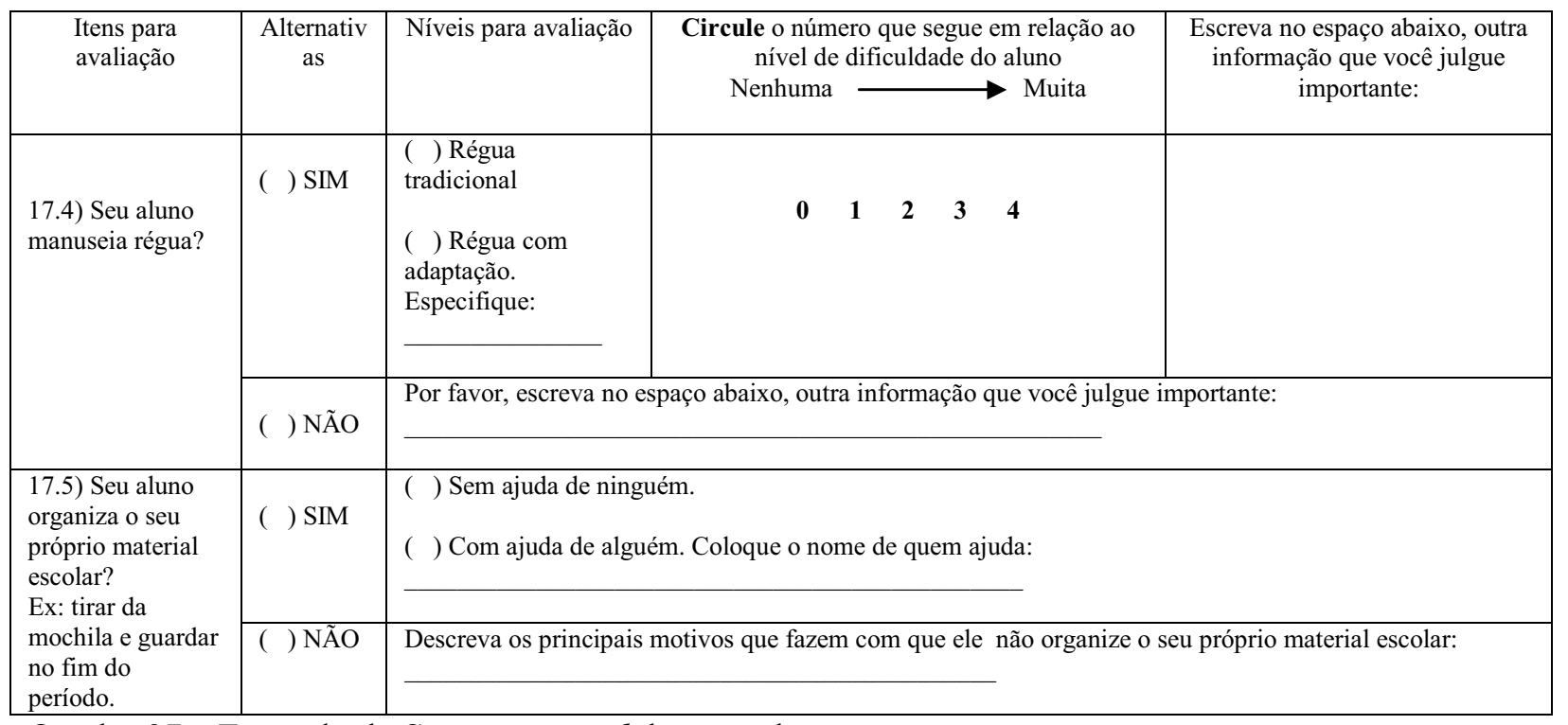

Quadro 37 - Exemplo da Seção principal da segunda versão

\begin{tabular}{|c|c|c|c|c|c|c|c|c|}
\hline \multirow[t]{2}{*}{$\begin{array}{l}\text { Itens para } \\
\text { avaliação }\end{array}$} & \multirow[t]{2}{*}{ Alternativas } & \multirow[t]{2}{*}{$\begin{array}{l}\text { Níveis para } \\
\text { avaliação }\end{array}$} & \multirow[t]{2}{*}{ Outras observações } & \multicolumn{5}{|c|}{$\begin{array}{c}\text { Circule o número que segue em } \\
\text { relação ao nível de dificuldade do } \\
\text { aluno }\end{array}$} \\
\hline & & & & Nenhuma & & & & Muita \\
\hline \multirow{3}{*}{$\begin{array}{l}\text { Seu aluno } \\
\text { manuseia } \\
\text { tesoura? }\end{array}$} & \multirow[t]{2}{*}{ ( ) SIM } & $\begin{array}{l}\text { ( ) Tesoura } \\
\text { tradicional }\end{array}$ & & $\mathbf{0}$ & 1 & 2 & 3 & 4 \\
\hline & & $\begin{array}{l}\text { ( ) Tesoura } \\
\text { adaptada }\end{array}$ & Descreva a adaptação:. & $\mathbf{0}$ & 1 & 2 & 3 & 4 \\
\hline & ( ) NÃO & \multicolumn{7}{|c|}{ Por favor, escreva no espaço abaixo, outra informação que você julgue importante: } \\
\hline \multirow{3}{*}{$\begin{array}{l}\text { Seu aluno } \\
\text { manuseia } \\
\text { régua? }\end{array}$} & \multirow[t]{2}{*}{ ( ) SIM } & $\begin{array}{l}\text { ( ) Régua } \\
\text { tradicional }\end{array}$ & $\begin{array}{l}\text { ( ) Madeira } \\
\text { ( ) Plástico } \\
\text { ( ) Outra: }\end{array}$ & $\mathbf{0}$ & 1 & 2 & 3 & 4 \\
\hline & & ( ) Adaptada & Descreva a adaptação: & $\mathbf{0}$ & 1 & 2 & 3 & 4 \\
\hline & & \multicolumn{7}{|c|}{ Por favor, escreva no espaço abaixo, outra informação que você julgue importante: } \\
\hline \multirow{3}{*}{$\begin{array}{l}\text { Seu aluno } \\
\text { organiza o seu } \\
\text { próprio } \\
\text { material } \\
\text { escolar? } \\
\text { Ex: tirar da } \\
\text { mochila e } \\
\text { guardar no fim } \\
\text { do período. }\end{array}$} & ( ) SIM & \multicolumn{2}{|c|}{ ( ) Com ajuda de alguém. Coloque o nome de quem ajuda: } & & & & & \\
\hline & & \multicolumn{2}{|c|}{ ( ) Sem ajuda de ninguém. } & $\mathbf{0}$ & 1 & 2 & 3 & 4 \\
\hline & ( ) NÃO & \multicolumn{7}{|c|}{ Descreva os principais motivos que fazem com que ele não organize o seu próprio material escolar: } \\
\hline
\end{tabular}

Quadro 38 - Exemplo da Seção principal da terceira versão

Para a construção da terceira versão, o protocolo de avaliação de preensão de Sankako, Oliveira e Manzini (2007) foi adaptado para o formato de figura e inserido na terceira versão do instrumento. A seguir, é observado um exemplo dessa tabela no Quadro 39: 


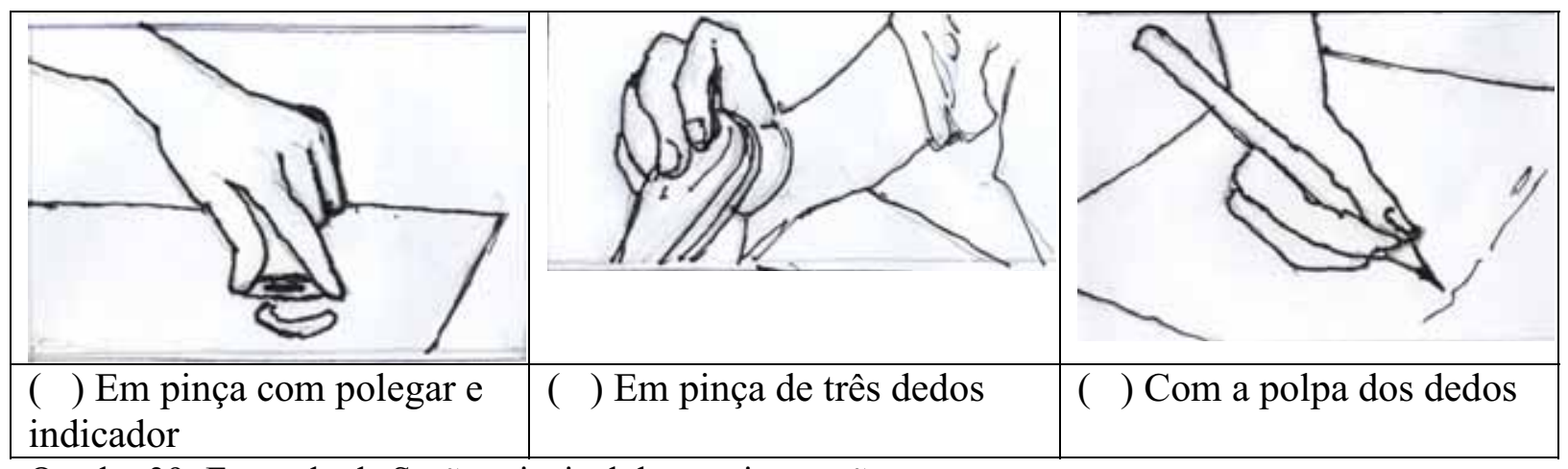

Quadro 39- Exemplo da Seção principal da terceira versão

Ainda para auxiliar a avaliação do aluno em relação aos reflexos tônico cervical assimétrico e tônico cervical simétrico, foram acrescentadas figuras ilustrativas baseadas nas figuras apresentadas no trabalho de Shirmer et al. (2007), que desenvolveram um manual de orientação para atendimento especializado para deficiente físico, como pode ser observado no Quadro 40:

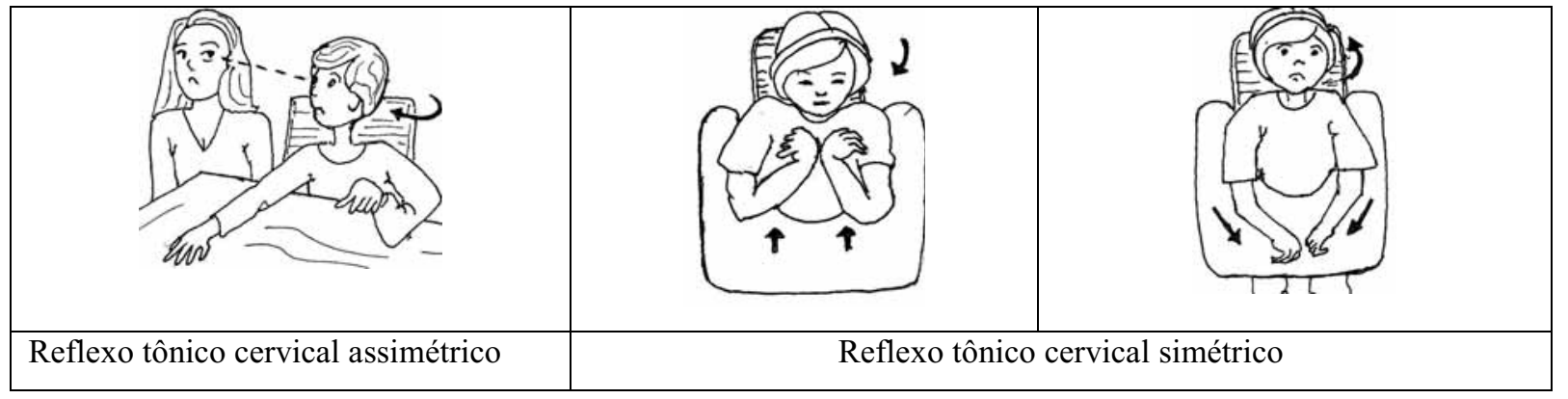

Quadro 40- Exemplo das ilustrações da terceira versão

À área "recursos do ambiente e do professor" que avaliava o acesso do aluno ao uso do computador, foi acrescentada uma tabela avaliativa sobre a presença de estímulo-surpresa no desencadeamento de padrão motor anormal, que pode ser observada no Quadro 41. A necessidade do acréscimo dessa tabela partiu da avaliação da aluna feita pelos pesquisadores, que, desencadeou espasmos tônicos extensores na presença do estímulo sonoro para indicar o acerto ou o erro da atividade que estava sendo realizada. Nos estudos de Magalhães e Lambertucci (2004), as autoras sugeriram que no uso de equipamentos suspensos, como balanço, há necessidade de demonstrar e instruir verbalmente todos os movimentos esperados para a execução da atividade. Observa-se que, apesar de as atividades estudas pelos autores serem diferentes do uso do computador, há em comum, a presença do estímulo-surpresa para o aluno, no qual o mesmo tipo de estratégia pode ser utilizado. 


\begin{tabular}{|c|c|c|c|}
\hline $\begin{array}{l}\text { Item para } \\
\text { avaliação }\end{array}$ & Habilidades & $\begin{array}{l}\text { Para que tipo de estímulo } \\
\text { (marque mais de um se } \\
\text { necessário) }\end{array}$ & Acrescente outras informações necessárias: \\
\hline \multirow{4}{*}{$\begin{array}{l}22.2) \text { Ele } \\
\text { desencadeia padrão } \\
\text { motor anormal na } \\
\text { presença de } \\
\text { estímulos } \\
\text { surpresa? } \\
\text { Ex: no caso de } \\
\text { acerto da atividade, } \\
\text { o programa do } \\
\text { computador ativa } \\
\text { uma música, nesse } \\
\text { momento, o aluno } \\
\text { assusta e } \\
\text { desencadeia um } \\
\text { padrão motor } \\
\text { anormal. }\end{array}$} & ( ) Sim, a todo momento. & \multirow{3}{*}{$\begin{array}{l}\text { ( ) sonoro } \\
\text { ( ) visual } \\
\text { ( ) outro: }\end{array}$} & \\
\hline & $\begin{array}{l}\text { ( ) Sim, mas só quando ele } \\
\text { não é avisado previamente que } \\
\text { o estímulo irá ocorrer. }\end{array}$ & & \\
\hline & $\begin{array}{l}\text { ( ) Não, mas só quando ele é } \\
\text { avisado previamente que o } \\
\text { estímulo irá ocorrer }\end{array}$ & & \\
\hline & $\begin{array}{l}\text { ( ) Não, ele não desencadeia } \\
\text { padrão anormal na presença de } \\
\text { estímulo surpresa }\end{array}$ & Não preencher & \\
\hline
\end{tabular}

Quadro 41- Exemplo da Seção principal da terceira versão

A "área de avaliação sobre a localização do aluno na sala", que pode ser observada no Quadro 42, sofreu consideráveis modificações, primeiro, com a incorporação de novos itens baseados no estudo de Calviño (1998). Segundo esse autor, há diferentes tipos de disposição em grupo, sendo compreendidos três tipos:

1. Disposição linear e restritivas, que pode ser identificada em três ocasiões, 1) com fileiras de pessoas uma atrás das outras, com o coordenador à frente da sala; 2) pessoas agrupadas em forma de "U" com o coordenador à frente da sala; 3) pessoas agrupadas sem nenhuma ordenação específica no fundo da sala, com o coordenador à frente dessas pessoas.

2. Disposição circular, na qual as pessoas e o coordenador são dispostos em círculo, sem que o coordenador ocupe local de destaque.

3. Grupos combinados, nos quais são abordados diferentes tipos de grupos, no entanto, são agrupamentos que dependem especificamente de uma estratégia específica.

Além disso, para uma melhor visualização dos itens avaliativos, optou-se por ilustrálos, como pode ser observado no Quadro 43:

\begin{tabular}{|c|c|c|c|c|c|}
\hline \multicolumn{6}{|c|}{$\begin{array}{l}\text { 28) QUAL A LOCALIZACAO DA CADEIRA DESSE ALUNO EM RELAÇÃO À SALA? Ex: primeira carteira da primeira fileira do } \\
\text { lado da porta. }\end{array}$} \\
\hline \multirow{2}{*}{$\begin{array}{l}\text { 28.1) Possibilita } \\
\text { a interação dele } \\
\text { com os outros } \\
\text { alunos? }\end{array}$} & \multirow{2}{*}{$\begin{array}{l}\text { 28.2) Possibilita a } \\
\text { interação dele } \\
\text { com o professor? }\end{array}$} & \multirow{2}{*}{$\begin{array}{l}28.3) \\
\text { Possibilita a } \\
\text { visualização } \\
\text { dele da lousa? }\end{array}$} & \multirow{2}{*}{$\begin{array}{l}28.4) \\
\text { Possibilita a } \\
\text { locomoção } \\
\text { dele ao } \\
\text { armário de } \\
\text { materiais? }\end{array}$} & \multicolumn{2}{|c|}{$\begin{array}{l}\text { 28.5) A localização dos alunos permanece fixa todos os } \\
\text { dias? }\end{array}$} \\
\hline & & & & $\mathrm{SIM} \downarrow$ & NÃO \\
\hline
\end{tabular}




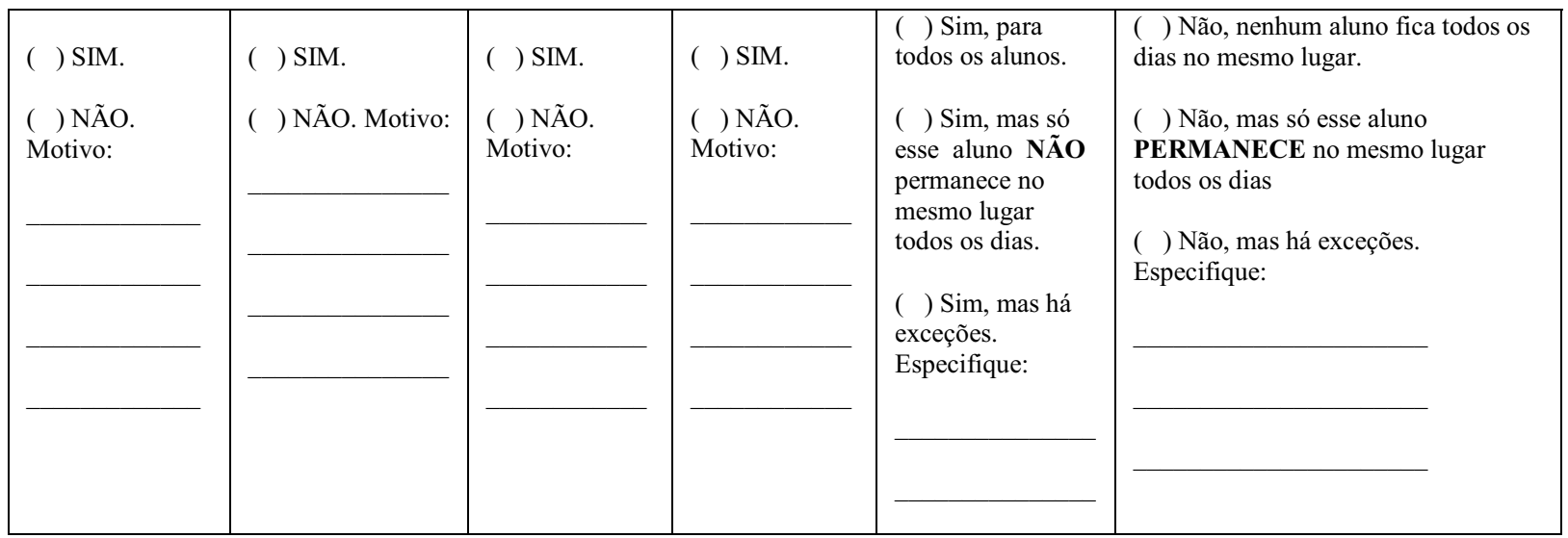

Quadro 42- Exemplo da Seção principal da segunda versão

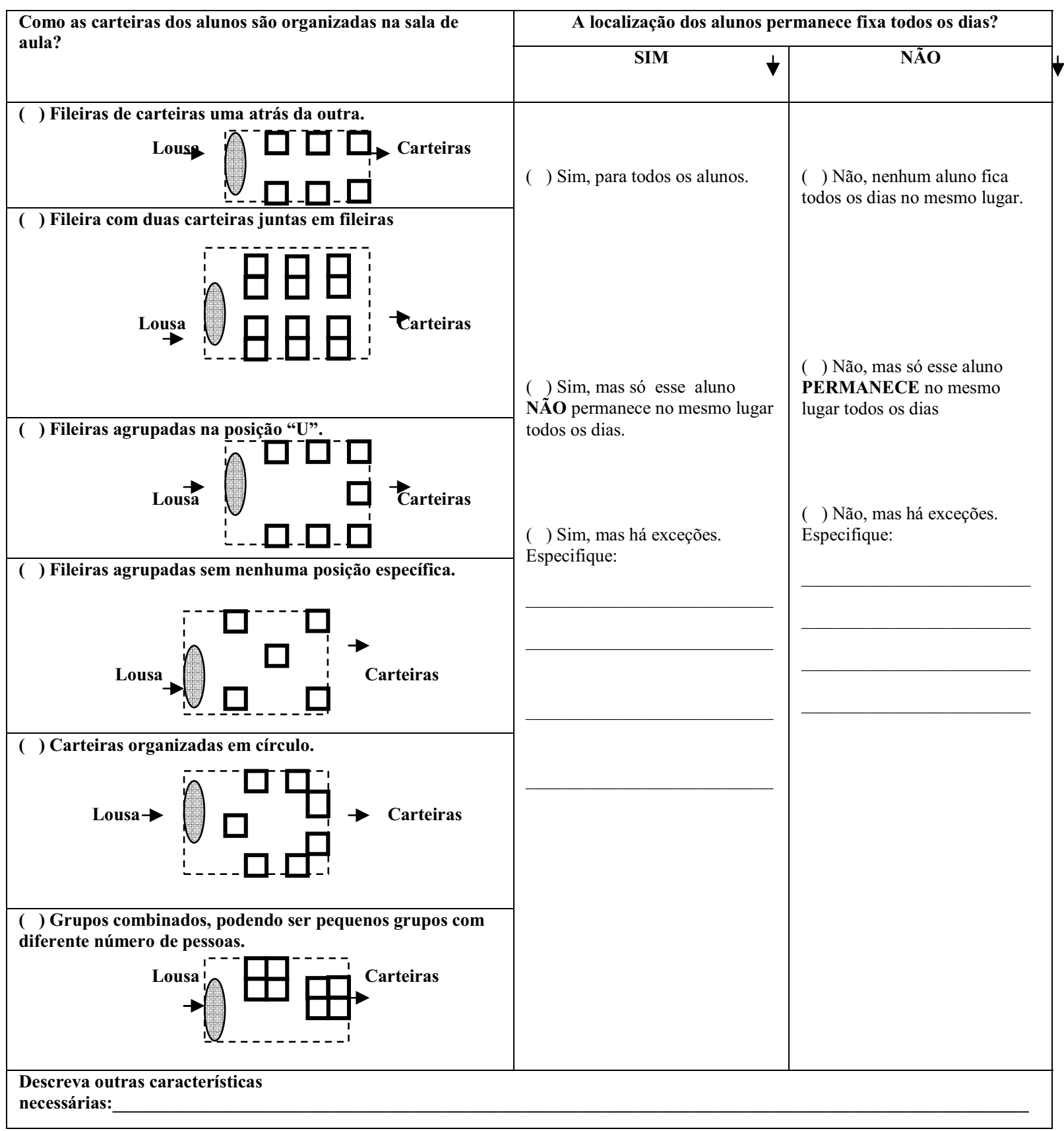

Quadro 43- Exemplo da Seção principal da terceira versão 
Com a avaliação da segunda versão do instrumento, optou-se por dividir a terceira versão em quatro partes, sendo que as duas primeiras foram destinadas à avaliação do aluno em diferentes contextos, e a terceira e a quarta parte, destinadas à sistematização de dados, planejamento de estratégias e adaptação do recurso pedagógico:

Parte I - avaliação das habilidades do aluno. Para avaliar o aluno com esta parte do instrumento, o aluno e o avaliador devem estar em um ambiente sem a interferência de barulho e/ou pessoas.

Parte II - avaliação do aluno em sala de aula. Para avaliar o aluno com esta parte do instrumento, o avaliador deve permanecer dentro da sala de aula para que as avaliações em relação a essas habilidades sejam feitas.

Parte III - sistematização dos dados da avaliação. Nessa parte os dados avaliados devem ser sistematizados observando as habilidades do aluno e as áreas que necessitam de intervenção.

Parte IV - planejamento de estratégias e escolha de materiais para adaptação. Essa parte serve para que as estratégias sejam planejadas e para que as decisões sobre o tipo de material para a adaptação do recurso sejam feitas de acordo com as características do aluno.

Além disso, com a avaliação da aluna observaram-se duas características importantes. A primeira foi que, a utilização dos materiais pedagógicos levados para complementar a avaliação com o uso do instrumento permitiu que o avaliador não seguisse criteriosamente a ordem dos itens trazidos no instrumento, pois, o uso de um único material pedagógico permitiu, de uma só vez, a avaliação de mais de uma dimensão do aluno, como, por exemplo, no momento da avaliação da escrita com o uso de recurso com peças do alfabeto móvel, foi possível avaliar: 1) a potencialidade do aluno em discriminar uma peça entre uma determinada quantidade; 2) a preensão de peças pequenas; 3) a habilidade de escrita; e 4) o auxílio da mão não dominante na realização de atividades.

A segunda característica observada foi que, houve necessidade de propor atividades para a avaliação da aluna com o uso do instrumento. Naquela ocasião, mesmo não sendo instruída pelo instrumento a necessidade do planejamento de atividades para a avaliação do aluno, os pesquisadores planejaram atividades e estratégias, que foram utilizadas em cada dimensão avaliada, levando em consideração o uso de cada recurso pedagógico. 


\subsection{Análise da terceira versão do instrumento por profissionais de área da Educação Especial}

Uma cópia da terceira versão do instrumento foi entregue no dia um de setembro a dois profissionais da área de Educação Especial, sendo docentes do Programa de PósGraduação em Educação e do departamento de educação especial (com formação em Fisioterapia e Terapia ocupacional), que foram membros da banca de qualificação deste estudo.

A qualificação aconteceu no dia 28 de setembro de 2009. Naquela ocasião, os profissionais analisaram o instrumento e sugeriram determinadas modificações para a quarta versão.

Dessa maneira, a quarta versão foi elaborada com as principais modificações em relação à terceira versão:

- Destinar o instrumento à avaliação de profissionais da área de Educação Especial, e, não mais, apenas ao professor especialista;

- Dividir o instrumento em apenas três partes, juntando a parte I e a parte II do instrumento;

- Elaborar um guia de aplicação do instrumento, descrevendo a importância de cada dimensão avaliada;

- Redefinir determinados quadros avaliativos, quanto à sua estruturação;

- Substituir terminologias que não eram compreendidas por outras específicas;

- Redefinir determinados quadros avaliativos, quanto ao seu conteúdo;

- Excluir determinadas dimensões avaliativas: 1) acesso ao computador e; 2) tipo de preensão; por já existirem instrumentos destinados a essas avaliações;

- Substituir o quadro de avaliação sobre mobiliário escolar por um quadro de observação, para que o profissional identifique, se o mobiliário fornece ou não uma postura adequada ao aluno, solicitando, quando necessário, o auxílio de um profissional habilitado para a indicação de outro mobiliário. 


\section{CONSTRUÇÃO DA QUARTA VERSÃO DO INSTRUMENTO}

Após a análise dos profissionais, a terceira versão foi reelaborada para definir a quarta versão (APÊNDICE B).

$\mathrm{Na}$ dimensão cognitiva, o item avaliativo que questionava "como é a escrita do aluno" sofreu duas modificações, a primeira, em relação à habilidade que respondia "a escrita está adequada às regras ortográficas, apresentando um baixo índice de erros em relação a escrita total do texto", foi retirada a frase em negrito; e a segunda em relação à retirada da régua avaliativa da segunda opção de resposta das habilidades, como podem ser observadas no Quadro 44 e no Quadro 45:

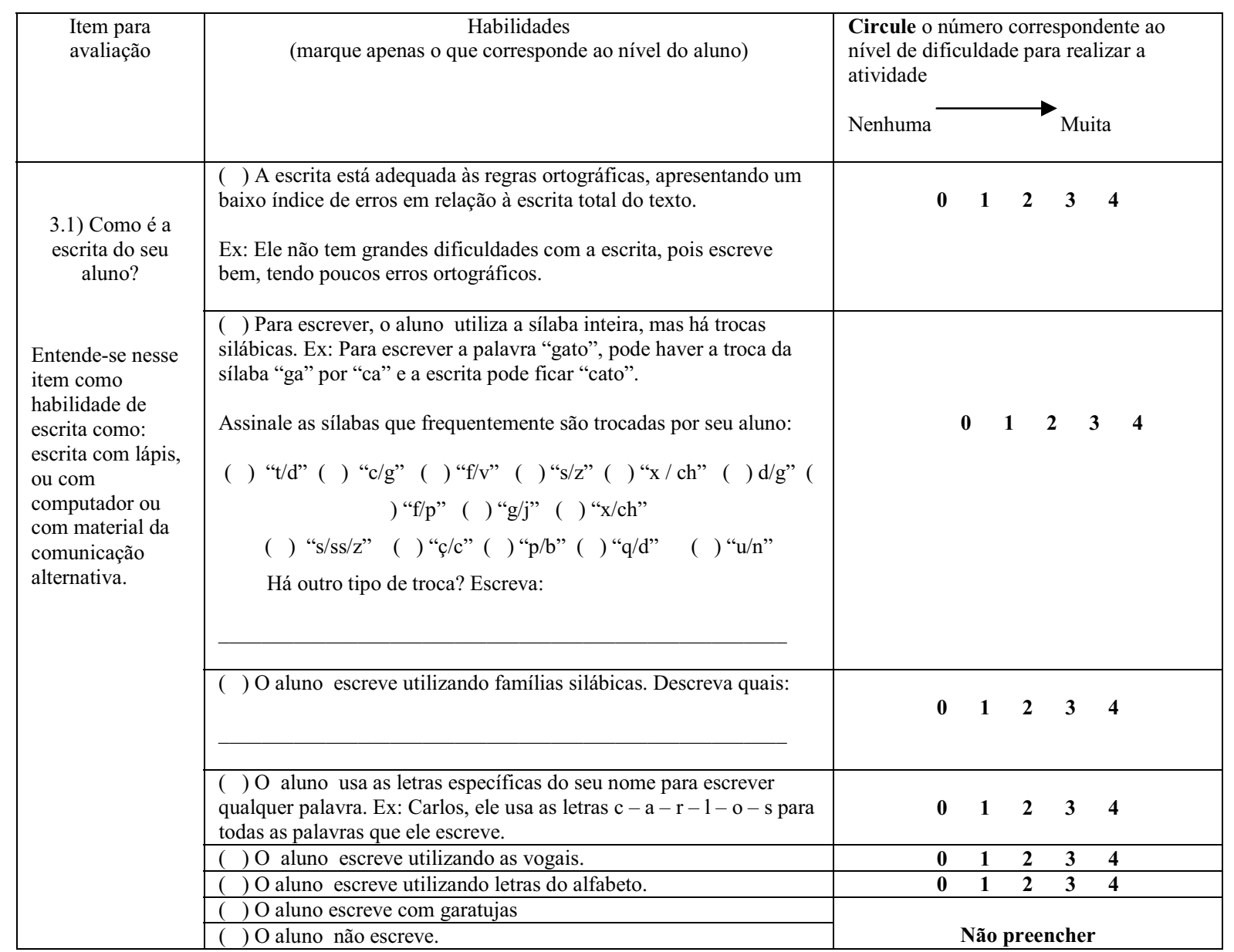

Quadro 44 - Exemplo da seção principal da terceira versão. 


\begin{tabular}{|c|c|c|c|c|c|c|}
\hline $\begin{array}{l}\text { Item para } \\
\text { avaliação }\end{array}$ & $\begin{array}{c}\text { Habilidades } \\
\text { (marque apenas o que corresponde ao nível do aluno) }\end{array}$ & \multicolumn{5}{|c|}{$\begin{array}{l}\text { Circule o número correspondente ao nível de } \\
\text { dificuldade para realizar a atividade } \\
\text { Nenhuma } \longrightarrow \text { Muita }\end{array}$} \\
\hline $\begin{array}{l}\text { 3.1) Como é a } \\
\text { escrita do seu } \\
\text { aluno? }\end{array}$ & $\begin{array}{l}\text { A escrita está adequada às regras ortográficas? } \\
\text { Ex: Ele não tem grandes dificuldades com a escrita, pois escreve } \\
\text { bem, tendo poucos erros ortográficos. } \\
\text { ( ) SIM ( ) NÃO }\end{array}$ & $\mathbf{0}$ & 1 & 2 & 3 & 4 \\
\hline \multirow[t]{6}{*}{$\begin{array}{l}\text { Entende-se nesse } \\
\text { item como } \\
\text { habilidade de } \\
\text { escrita como: } \\
\text { escrita com lápis, } \\
\text { ou com } \\
\text { computador ou } \\
\text { com material da } \\
\text { comunicação } \\
\text { alternativa. }\end{array}$} & 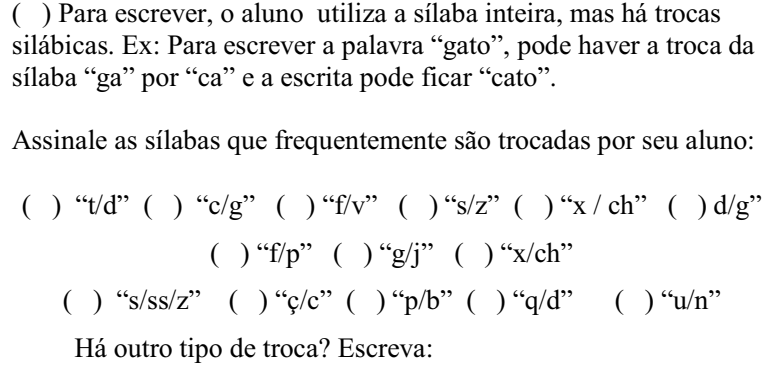 & \multicolumn{5}{|c|}{ Não preencher } \\
\hline & ( ) O aluno escreve utilizando famílias silábicas. Descreva quais: & $\mathbf{0}$ & 1 & 2 & 3 & 4 \\
\hline & $\begin{array}{l}\text { ( ) } \mathrm{O} \text { aluno usa as letras específicas do seu nome para escrever } \\
\text { qualquer palavra. Ex: Carlos, ele usa as letras } \mathrm{c}-\mathrm{a}-\mathrm{r}-1-\mathrm{o}-\mathrm{s} \\
\text { para todas as palavras que ele escreve. }\end{array}$ & $\mathbf{0}$ & 1 & 2 & 3 & 4 \\
\hline & ( ) $\mathrm{O}$ aluno escreve utilizando as vogais. & $\mathbf{0}$ & 1 & 2 & 3 & 4 \\
\hline & ( ) $\mathrm{O}$ aluno escreve utilizando letras do alfabeto. & $\mathbf{0}$ & 1 & 2 & 3 & 4 \\
\hline & ( ) O aluno escreve com garatujas & \multicolumn{5}{|c|}{ Não preencher } \\
\hline
\end{tabular}

Quadro 45 - Exemplo da seção principal da quarta versão.

Em relação à substituição de terminologias vagas, houve substituições como, por exemplo, no item que avaliava a sensibilidade tátil do aluno em relação ao contato com diferentes tipos de superfície. Este item avaliativo questionava, "o aluno apresenta incompatibilidade tátil com relação à alguma superfície?” (vide Quadro 46), por unanimidade, os profissionais concluíram que esse termo não era adequado para a avaliação pretendida, sendo, substituída por "Como o aluno reage ao contato com determinadas superficies?". Além dessa mudança, houve outras adequações naquele quadro para direcionar a avaliação pretendida, como pode ser observado no Quadro 47:

\begin{tabular}{|c|c|c|c|c|c|c|}
\hline \multirow[t]{2}{*}{ Item avaliativo } & \multirow[t]{2}{*}{ Habilidades } & \multicolumn{5}{|c|}{$\begin{array}{l}\text { Circule o número que segue em relação ao } \\
\text { nível de dificuldade do aluno }\end{array}$} \\
\hline & & \multicolumn{5}{|c|}{ 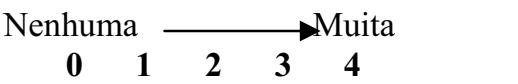 } \\
\hline & ( ) Sim, as superfícies lisas & $\mathbf{0}$ & 1 & 2 & 3 & 4 \\
\hline $\begin{array}{l}\text { 18.4) O aluno } \\
\text { apresenta } \\
\text { Incompatibilidad } \\
\text { e tátil com } \\
\text { relação a alguma } \\
\text { determinada } \\
\text { superfície? }\end{array}$ & ( ) Sim, as superfícies onduladas & $\mathbf{0}$ & 1 & 2 & 3 & 4 \\
\hline
\end{tabular}




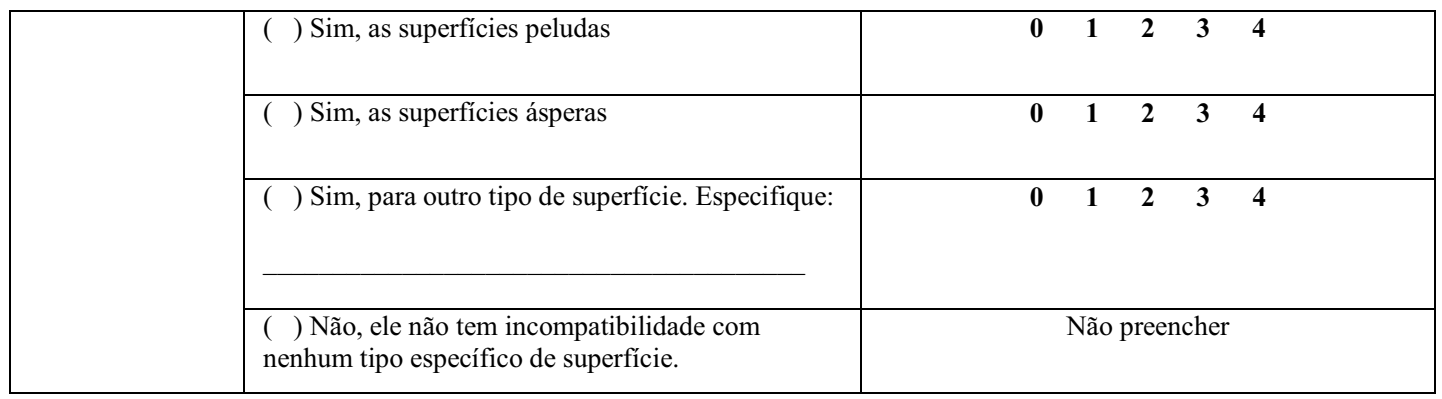

Quadro 46 - Exemplo da seção principal da terceira versão.

\begin{tabular}{|c|c|c|c|c|c|c|c|c|}
\hline \multirow{4}{*}{$\begin{array}{l}\begin{array}{c}\text { Item } \\
\text { avaliativo }\end{array} \\
\\
\\
15.4) \\
\text { Como o } \\
\text { aluno } \\
\text { reage ao } \\
\text { contato } \\
\text { com } \\
\text { determina } \\
\text { das } \\
\text { superfície } \\
\text { s? }\end{array}$} & \multirow{2}{*}{$\begin{array}{l}\text { Habilidades } \\
\begin{array}{l}\text { Superfícies } \\
\text { lisas }\end{array}\end{array}$} & \multicolumn{2}{|c|}{$\begin{array}{l}\text { O aluno nomeia o } \\
\text { tipo de superfície } \\
\text { através do tato? }\end{array}$} & \multicolumn{2}{|c|}{$\begin{array}{c}\text { O aluno discrimina, } \\
\text { mas não nomeia } \\
\text { quando esta em } \\
\text { contato com essa } \\
\text { superfície? }\end{array}$} & \multicolumn{2}{|c|}{$\begin{array}{l}\text { O aluno reage de } \\
\text { alguma maneira } \\
\text { quando tem } \\
\text { contato com essa } \\
\text { superfície? }\end{array}$} & \multirow{2}{*}{$\begin{array}{l}\text { Como é a reação do aluno? } \\
\text { ( ) Normal } \\
\text { ( ) Pouco exagerada } \\
\text { ( ) Muito exagerada } \\
\text { ( ) Ele se recusa a tocar } \\
\text { nessa superfície }\end{array}$} \\
\hline & & $\begin{array}{l}\text { ( ) } \\
\text { Não }\end{array}$ & ( ) $\mathrm{Sim}$ & ( ) Não & ( ) $\mathrm{Sim}$ & $\begin{array}{c}(\text { ( ) } \\
\text { Não }\end{array}$ & $\begin{array}{l}(\text { ) } \\
\text { Sim }\end{array}$ & \\
\hline & $\begin{array}{l}\text { Superfícies } \\
\text { onduladas }\end{array}$ & $\begin{array}{l}\text { ( ) } \\
\text { Não }\end{array}$ & ( ) $\mathrm{Sim}$ & ( ) Não & ( ) $\mathrm{Sim}$ & $\begin{array}{l}\text { ( ) } \\
\text { Não }\end{array}$ & ( ) & $\begin{array}{l}\text { ( ) Normal } \\
\text { ( ) Pouco exagerada } \\
\text { ( ) Muito exagerada } \\
\text { ( ) Ele se recusa a tocar } \\
\text { nessa superfície }\end{array}$ \\
\hline & $\begin{array}{l}\text { Superfícies } \\
\text { peludas }\end{array}$ & $\begin{array}{l}\text { ( ) } \\
\text { Não }\end{array}$ & ( ) $\mathrm{Sim}$ & ( ) Não & ( ) $\mathrm{Sim}$ & $\begin{array}{l}\text { ( ) } \\
\text { Não }\end{array}$ & ( ) & $\begin{array}{l}\text { ( ) Normal } \\
\text { ( ) Pouco exagerada } \\
\text { ( ) Muito exagerada } \\
\text { ( ) Ele se recusa a tocar } \\
\text { nessa superfície }\end{array}$ \\
\hline & $\begin{array}{l}\text { Superfícies } \\
\text { com material } \\
\text { imitando } \\
\text { cabelo. }\end{array}$ & $\begin{array}{l}\text { ( ) } \\
\text { Não }\end{array}$ & ( ) $\mathrm{Sim}$ & ( ) Não & ( ) $\operatorname{Sim}$ & $\begin{array}{l}(\text { ) } \\
\text { Não }\end{array}$ & $\begin{array}{l}(\text { ) } \\
\text { Sim }\end{array}$ & $\begin{array}{l}\text { ( ) Normal } \\
\text { ( ) Pouco exagerada } \\
\text { ( ) Muito exagerada } \\
\text { ( ) Ele se recusa a tocar } \\
\text { nessa superfície }\end{array}$ \\
\hline & $\begin{array}{l}\text { Superfícies } \\
\text { ásperas }\end{array}$ & $\begin{array}{l}\text { ( ) } \\
\text { Não }\end{array}$ & ( ) $\mathrm{Sim}$ & ( ) Não & ( ) $\mathrm{Sim}$ & $\begin{array}{l}\text { ( ) } \\
\text { Não }\end{array}$ & $\begin{array}{l}\text { ( ) } \\
\text { Sim }\end{array}$ & $\begin{array}{l}\text { ( ) Normal } \\
\text { ( ) Pouco exagerada } \\
\text { ( ) Muito exagerada } \\
\text { ( ) Ele se recusa a tocar } \\
\text { nessa superfície }\end{array}$ \\
\hline & $\begin{array}{l}\text { Outro tipo de } \\
\text { superfície. } \\
\text { Especifique: }\end{array}$ & $\begin{array}{l}(\text { ( ) } \\
\text { Não }\end{array}$ & ( ) $\mathrm{Sim}$ & ( ) Não & ( ) $\mathrm{Sim}$ & $\begin{array}{c}(\text { ( ) } \\
\text { Não }\end{array}$ & $\begin{array}{l}\text { ( ) } \\
\text { Sim }\end{array}$ & $\begin{array}{l}\text { ( ) Normal } \\
\text { ( ) Pouco exagerada } \\
\text { ( ) Muito exagerada } \\
\text { ( ) Ele se recusa a tocar } \\
\text { nessa superfície }\end{array}$ \\
\hline
\end{tabular}

Quadro 47 - Exemplo da seção principal da quarta versão.

Além dessa modificação, na dimensão sensorial foi acrescentado o quadro para avaliar a sensibilidade térmica do aluno, como pode ser observado no Quadro 48:

\begin{tabular}{|c|l|l|c|c|c|}
\hline $\begin{array}{c}\text { Item } \\
\text { avaliativo }\end{array}$ & Habilidades & $\begin{array}{l}\text { O aluno } \\
\text { nomeia o } \\
\text { tipo de } \\
\text { temperatura } \\
\text { pelo tato? }\end{array}$ & $\begin{array}{c}\text { O aluno } \\
\text { discrimina, mas } \\
\text { não nomeia } \\
\text { quando esta em } \\
\text { contato com essa } \\
\text { temperatura? }\end{array}$ & $\begin{array}{c}\text { O aluno reage de alguma } \\
\text { maneira quando tem } \\
\text { contato com essa } \\
\text { temperatura? }\end{array}$ & Como é a reação do aluno? \\
\hline
\end{tabular}




\begin{tabular}{|c|c|c|c|c|c|c|c|c|}
\hline \multirow{2}{*}{$\begin{array}{l}15.5) \text { Como o } \\
\text { aluno reage } \\
\text { ao contato } \\
\text { com } \\
\text { determinadas } \\
\text { temperaturas } \\
?\end{array}$} & $\begin{array}{l}\text { Temperatura } \\
\text { fria }\end{array}$ & $\begin{array}{l}\text { ( ) } \\
\text { Não }\end{array}$ & $\begin{array}{l}(\text { ) } \\
\text { Sim }\end{array}$ & $\begin{array}{l}\text { ( ) } \\
\text { Não }\end{array}$ & $\begin{array}{l}(\text { ) } \\
\text { Sim }\end{array}$ & $\begin{array}{l}(\text { ) } \\
\text { Não }\end{array}$ & ( ) $\operatorname{Sim}$ & $\begin{array}{l}\text { ( ) Normal } \\
\text { ( ) Pouco exagerada } \\
\text { ( ) Muito exagerada } \\
\text { ( ) Ele se recusa a tocar nessa superfície }\end{array}$ \\
\hline & $\begin{array}{l}\text { Temperatura } \\
\text { quente }\end{array}$ & $\begin{array}{l}\text { ( ) } \\
\text { Não }\end{array}$ & $\begin{array}{l}(\text { ) } \\
\text { Sim }\end{array}$ & $\begin{array}{l}\text { ( ) } \\
\text { Não }\end{array}$ & $\begin{array}{l}(\text { ) } \\
\text { Sim }\end{array}$ & $\begin{array}{l}\text { ( ) } \\
\text { Não }\end{array}$ & ( ) $\operatorname{Sim}$ & $\begin{array}{l}\text { ( ) Normal } \\
\text { ( ) Pouco exagerada } \\
\text { ( ) Muito exagerada } \\
\text { ( ) Ele se recusa a tocar nessa superfície }\end{array}$ \\
\hline
\end{tabular}

Quadro 48 - Exemplo da seção principal da quarta versão.

O quadro sobre a sistematização dos dados, na terceira versão, era como demonstrado no Quadro 49:

30) De acordo com a avaliação realizada, descreva em poucas palavras o que se pede:

\begin{tabular}{|c|c|}
\hline HABILIDADES DO ALUNO & \\
\hline ÁREAS QUE PRECISAM DE INTERVENÇÃO \\
\hline
\end{tabular}

Quadro 49 - Exemplo da seção principal da terceira versão.

Com a reformulação, esse quadro foi dividido em dois quadros, sendo o primeiro, referente às habilidades do aluno; o segundo, referente às necessidades do aluno. Além disso, os quadros da sistematização das habilidades e necessidades do aluno passaram a apresentar os nomes das dimensões avaliadas para guiar o preenchimento do avaliador, como pode ser observado no Quadro 50 e Quadro 51:

\begin{tabular}{|l|}
\hline \multicolumn{1}{|c|}{ HABILIDADES DO ALUNO, ou seja, o que ele faz: } \\
\hline Dimensão cognitiva: \\
\hline Dimensão da linguagem e comunicação: \\
\hline Dimensão motora e material pedagógico: \\
\hline Dimensão sensorial: \\
\hline Dimensão acadêmica: \\
\hline Dimensão social: \\
\hline Dimensão motora, posicionamento: \\
\hline
\end{tabular}

Quadro 50 - Exemplo da seção principal da quarta versão 


\begin{tabular}{|l|}
\hline \multicolumn{1}{|c|}{ DIMENSÕES QUE NECESSITAM DE INTERVENÇ̃̃O: } \\
\hline Dimensão cognitiva: \\
\hline Dimensão da linguagem e comunicação: \\
\hline Dimensão motora e material pedagógico: \\
\hline Dimensão sensorial: \\
\hline Dimensão acadêmica: \\
\hline Dimensão social: \\
\hline Dimensão motora, posicionamento: \\
\hline
\end{tabular}

Quadro 51 - Exemplo da seção principal da quarta versão

Além disso, foi acrescentado o quadro intitulado "informações específicas" para anotação de dados do contexto familiar e das preferências do aluno, como pode ser observado no Quadro 52:

\begin{tabular}{|l|}
\hline \multicolumn{1}{|c|}{ INFORMAÇÕES ESPECÍFICAS: } \\
\hline DADOS DO CONTEXTO FAMILIAR: \\
\hline DADOS SOBRE AS PREFERENCIAS DO ALUNO: \\
\hline
\end{tabular}

Quadro 52 - Exemplo da seção principal da quarta versão

E outro quadro intitulado "outras informações necessárias", para o avaliador acrescentar dados que não foram contemplados no instrumento, como pode ser observado no Quadro 53: 
O quadro sobre as "características da paralisia cerebral", na terceira versão, pretendia avaliar o tipo de tônus apresentado pelo aluno (como observado no Quadro 54). Sobre essa questão, os profissionais sugeriram a retirada desse item, por dois motivos: 1) por ser uma característica que dificilmente poderia ser avaliada apenas com o protocolo; 2) e pela formação de determinados profissionais que utilizariam o protocolo, como, por exemplo, o professor de educação especial, que, mesmo possuindo habilitação em educação especial dificilmente poderia realizar esse tipo de avaliação. Nesse sentido, esse quadro foi substituído pela classificação da paralisia cerebral (veja Quadro 55), que poderá guiar o profissional na escolha de materiais, sendo coerentes com as possibilidades motoras de cada aluno, de acordo com o tipo de paralisia cerebral.

\begin{tabular}{|c|c|c|}
\hline Item para avaliação & Alternativas & Acrescente em poucas palavras outras informações necessárias: \\
\hline $\begin{array}{l}\text { 32.1) O aluno apresenta } \\
\text { que tipo de tônus } \\
\text { muscular? }\end{array}$ & $\begin{array}{l}\text { ( ) Ele apresenta } \\
\text { rigidez muscular } \\
\text { (hipertonia) } \\
\text { ( ) Ele apresenta } \\
\text { flacidez muscular } \\
\text { (hipotonia) } \\
\text { ( ) Não tem } \\
\text { alteração de tônus } \\
\text { ( ) Não sei }\end{array}$ & \\
\hline
\end{tabular}

Quadro 54 - Exemplo da seção principal da terceira versão.

\begin{tabular}{|c|c|c|}
\hline Item para avaliação & Alternativas & $\begin{array}{l}\text { Acrescente em poucas palavras outras informações } \\
\text { necessárias: }\end{array}$ \\
\hline $\begin{array}{l}\text { 30.1) Qual é o tipo de } \\
\text { paralisia cerebral do } \\
\text { aluno avaliado? }\end{array}$ & $\begin{array}{l}\text { ( ) Espástica } \\
\text { ( ) Discinética } \\
\text { ( ) Atáxica } \\
\text { ( ) Hipotônica } \\
\text { ( ) Mista } \\
\text { ( ) Não sei }\end{array}$ & \\
\hline $\begin{array}{l}\text { 30.2) Qual é a } \\
\text { classificação } \\
\text { topográfica? }\end{array}$ & $\begin{array}{l}\text { ( ) hemiplegia } \\
\text { ( ) diplegia } \\
\text { ( ) quadriplegia } \\
\text { ( ) Não sei }\end{array}$ & \\
\hline
\end{tabular}

Quadro 55 - Exemplo da seção principal da quarta versão.

Além dessas modificações, foi acrescentado no final do instrumento um apêndice com as referências de determinados instrumentos de avaliação já publicados que poderão 
complementar a avaliação do aluno, na área visual, na área comunicativa, na área de preensão, para adaptação de recursos pedagógicos e na área de acesso ao computador, caso o profissional julgue necessário.

À elaboração da quarta versão do instrumento, acrescentou-se, ainda, um guia para direcionar a avaliação (APÊNDICE A). O guia para avaliação foi elaborado com o seguinte conteúdo: 1) introdução ao tema, contemplando: a) a importância da avaliação para a adaptação do recurso pedagógico; b) indicação das dimensões que devem ser avaliadas no aluno com paralisia cerebral; c) elaboração de estratégias no ensino do aluno com paralisia cerebral; 2) apresentação do protocolo; 3) descrição do instrumento; 4) orientação sobre o preenchimento do protocolo. 


\section{CONSIDERAÇÕES FINAIS}

A problematização deste estudo partiu da necessidade de garantir o acesso às atividades para alunos com paralisia cerebral matriculados no ensino fundamental. Nessa perspectiva, observou-se que, era preciso adaptar o recurso pedagógico e disponibilizar um ambiente que oferecesse oportunidades de ensino.

Com a revisão bibliográfica, concluiu-se que, uma avaliação que coletasse dados sobre as características dos alunos com paralisia cerebral, as condições acessíveis ou não oferecidas pelo meio, em relação aos materiais pedagógicos, mobiliários, interação social, planejamento de ensino e estratégia, poderia direcionar a adaptação do recurso pedagógico e o planejamento de estratégia para o ensino de acordo com as potencialidades e necessidades desses alunos.

Encontraram-se, na literatura, diversos instrumentos de avaliação, no entanto, não foi identificado nenhum instrumento com o objetivo específico de avaliar essas áreas de habilidade do aluno e do ambiente escolar visando a adaptação do recurso pedagógico e planejamento de estratégias para alunos com paralisia cerebral.

Dessa maneira, o objetivo deste estudo foi desenvolver um instrumento de avaliação que auxiliasse o profissional em educação especial a avaliar o aluno com paralisia cerebral no contexto da sala de ensino comum das séries iniciais do Ensino Fundamental, visando prescrever ou adaptar recursos pedagógicos e planejar estratégia para o ensino.

Após a construção da sua primeira versão, o instrumento foi utilizado pelas participantes deste estudo. Naquele momento, as dúvidas e sugestões sobre a sua utilização favoreceram a melhora das áreas de avaliação que já existiam, para adequação estrutural do instrumento e para a inclusão de áreas que o instrumento não possuía, constituindo-se na segunda versão do instrumento.

A análise e a utilização da segunda versão, por outras participantes e profissionais da área da educação especial, formaram a base para construção da sua terceira versão.

Esta foi analisada por outros dois profissionais da área de educação especial, que sugeriram mudanças em determinados itens de avaliação e a construção de um guia para avaliação com o uso do instrumento, dando origem à quarta versão do protocolo.

Ao analisar o processo de elaboração das versões do protocolo, destaca-se a contribuição dos profissionais que participaram da pesquisa. Cada qual, com um conhecimento específico da sua área de formação (pedagogos com Habilitação em deficiência 
física, psicólogo, fisioterapeuta e terapeuta ocupacional), todos com experiência em atuar na área de educação especial, contribuiu para que o protocolo tornasse um instrumento de avaliação apto a avaliar diferentes dimensões do aluno, incluindo, as características do contexto da sala de aula.

Ao finalizar este estudo, por um lado, é possível pontuar determinadas contribuições que o uso do protocolo para prescrição ou adaptação de recurso pedagógico acrescentou: 1) à formação das participantes e 2) à prática do profissional de educação especial que utilizará o instrumento.

Em relação à formação das participantes, a elaboração desta pesquisa contribui para: 1.1) instrumentalizá-las, pois, com o uso do instrumento, elas avaliaram o aluno do estágio considerando não só as suas características, mas, também, as características do ambiente escolar em que ele estava inserido; 1.2) proporcionar reflexão para avaliar as capacidades do aluno e as áreas em que ele necessita de intervenção, e não focalizando as suas dificuldades e, 1.3) capacitá-las a avaliar o aluno com paralisia cerebral com o uso do atual instrumento.

Em relação ao uso do instrumento pelo profissional de educação especial, é possível evidenciar as contribuições acrescentadas à sua prática:

1. Amplia o foco de avaliação. O protocolo avalia nove dimensões: dimensão cognitiva, dimensão da linguagem e da comunicação; dimensão motora e material pedagógico; dimensão social; dimensão do contexto familiar; dimensão das preferências individuais; dimensão acadêmica: recursos do ambiente e do professor; dimensão social: interação do aluno e dimensão motora: posicionamento;

2. Avalia a potencialidade e a necessidade do aluno, e não só as suas limitações. $O$ protocolo guia a avaliação do profissional para identificar as potencialidades do aluno e as dimensões, nas quais, o aluno necessita de intervenção, sempre com foco no que o aluno faz, seja com ajuda ou sozinho; seja com recursos pedagógicos comuns ou com adaptação, nunca focalizando o que ele não pode fazer devido às suas limitações;

3. Sugere o uso de recurso adaptados. No decorrer do protocolo, em determinadas avaliações, o profissional encontra, em forma de pergunta avaliativa, a indicação de alguns recursos adaptados, que, caso o profissional não os conheçam antes, com a utilização do instrumento, ele adquire esse conhecimento, pode servir de sugestão para as próximas atividades do aluno, caso o avaliador julgue necessário; 
4. Sugere o uso de estratégias. Além da parte específica para reflexões para estratégia, o protocolo disponibiliza ainda, algumas estratégias, em forma de perguntas avaliativas, ao longo do protocolo, que podem servir de sugestões para as próximas atividades, caso o avaliador identifique essa necessidade no aluno;

5. Sistematiza os dados por dimensões avaliadas. A parte da sistematização de dados permite que o profissional descreva em cada dimensão avaliada, a potencialidade e a necessidade do aluno e, ainda, disponibiliza um espaço para que o profissional descreva os dados familiares e as preferências do aluno;

6. Relaciona a prescrição ou adaptação do recurso com os dados da paralisia cerebral. O guia de avaliação do protocolo contém uma breve introdução sobre a importância de avaliar o aluno com paralisia cerebral para escolher o material para adaptação. Além disso, há disponibilizado no protocolo, uma parte destinada à escolha de categorias para adaptação do recurso, que relaciona as características do aluno com a escolha e a adaptação do recurso. Mesmo não englobando todas as possíveis características do aluno com paralisia cerebral, o conteúdo do protocolo permite que o avaliador identifique a necessidade de escolher dentre os materiais, o mais adequado para a adaptação, visando potencializar o desenvolvimento do aluno;

7. Disponibiliza referências de outros instrumentos de avaliação publicados. Ao final do instrumento, em forma de apêndice, são disponibilizadas referências de instrumentos de avaliação que poderão complementar a avaliação do aluno, caso o avaliador identifique essa necessidade.

Por outro lado, é possível pontuar determinados fatores que poderão ser considerados desfavoráveis, caso não sejam observados pelo profissional que utilizará o instrumento:

1) O profissional precisará de uma capacitação para utilizar o instrumento. Ao longo da elaboração deste estudo, observou-se que ser for oferecida uma capacitação sobre como utilizar o instrumento, o profissional com formação em educação especial terá mais facilidade em avaliar o aluno, sistematizar os dados da avaliação e prescrever ou adaptar um recurso pedagógico;

2) Determinadas dimensões de avaliação são sensíveis à avaliação de dois profissionais em um mesmo aluno. A avaliação de um mesmo aluno por dois profissionais poderá apresentar diferenças, como, por exemplo, na avaliação do nível de dificuldade do aluno para desenvolver determinadas atividades, pois, o nível de dificuldade no 
desenvolvimento de um aluno pode ser interpretado de maneira diferente pelos avaliadores em relação à escala numérica proposta no instrumento (grau de dificuldade $0,1,2,3$ ou 4);

3) A avaliação poderá ter que ser realizada em mais de um dia ou de um período. $O$ avaliador precisará julgar com competência o melhor momento para encerrar a avaliação em um determinado tempo e recomeçar no dia posterior. Isso deverá ser considerado pelo fato de que a fadiga pode influenciar no resultado da avaliação, na medida em que, o aluno e o avaliador podem demonstrar sinais de cansaço e perder o interesse e a atenção pela atividade, devido ao cansaço físico e mental e;

4) O avaliador deverá disponibilizar os recurso pedagógicos mencionados ao longo do instrumento. Anteriormente à avaliação, o avaliador deverá disponibilizar os recursos pedagógicos adaptados ou não adaptados mencionados como critérios para a avaliação de determinada dimensão, o que poderá dificultar o uso do instrumento, em determinados casos em que o avaliador não conhecer os recursos descritos no instrumento.

Apesar de haver características do uso do instrumento que poderão limitar o seu uso, o presente estudo indicou que o conjunto das contribuições, além de guiar a prescrição ou adaptação do recurso pedagógico, favorece o profissional a observar as situações de interação social do aluno com seus parceiros de sala, para, em seguida, planejar estratégias favoráveis a essa interação.

Acredita-se, assim, que o atual instrumento possa favorecer o ensino do aluno com paralisia cerebral, possibilitando que o profissional adapte o recurso de acordo com as características do aluno, planeje estratégias favoráveis ao ensino, e planeje atividades que atendam suas reais necessidades acadêmicas no contexto da escola regular. 


\section{REFERÊNCIA}

ANTUNES, C. A sala de aula de Geografia e história: inteligências múltiplas, aprendizagem significativa e competências no dia-a-dia. Campinas: Papirus, 2001.

ALPINO, A. M. S. Consultoria colaborativa escolar do fisioterapeuta: acessibilidade e participação do aluno com paralisia cerebral em questão. 2008. 190f. Tese (Doutorado) Universidade Federal de São Carlos, 2008.

ALVES, D. O; GOTTI, M. O. Atendimento educacional especializado: concepção, princípios e aspectos Organizacionais. Ministério da Educação/Secretaria da Educação Especial (Org.). III Seminário Nacional de formação de Gestores e Educadores: Ensaios pedagógicos, Brasília, p. 267 - 272, 2006.

ARAÚJO, R. C. T; MANZINI, E. J. Recursos de ensino na escolarização do aluno com deficiência física. In: MANZINI, E. J. (Org.). Linguagem, cognição e ensino do aluno com deficiência. Marília: UNESP Publicações, 2001. p. 1-12.

ARAÚJO, R. C. T.; OMOTE, S. Atribuição de gravidade à deficiência física em função da extensão do acometimento e do contexto escolar. Revista Brasileira de Educação Especial. Marília: ABPEE, v. 11, n.2, p. 241 - 254, 2005. Quadrimestral.

AUDI, E. M. M. Protocolo para avaliação de acessibilidade física em escolas de ensino fundamental. 2004. 228 f. Dissertação (Mestrado em Educação) - Faculdade de Filosofia e Ciências, Universidade Estadual Paulista, Marília, 2004.

AUDI, M. Estudo comparativo do comportamento motor de membro superior em encefalopatias que fazem uso de pulseira estabilizadora. 2006. 112f. Dissertação (Mestrado em Educação) - Faculdade de Filosofia e Ciências, Universidade Estadual Paulista, Marília, 2006.

AUDI, E. M. M.; MAZINI, E. J. Protocolo para avaliação de acessibilidade física em escolas do ensino fundamental: um guia para gestores e educadores. Marília: ABPEE, 2006.

BALEOTTI, L. R. Experiência escolar do aluno com deficiência física no ensino comum: o ponto de vista do aluno. 2001. 78f. Dissertação (Mestrado em Educação) - Faculdade de Filosofia e Ciências, Universidade Estadual Paulista, Marília, 2001. 
BARBOSA, A. J. G.; AZEVEDO, P. R.; CASELATTO, P. Atitudes dos pares em relação aos alunos com necessidades especiais: socialização e inclusão escolar. In: MANZINI, E. J. (Org.). Inclusão do aluno com deficiência na escola: os desafios continuam. Marília: ABPEE/FAPESP, 2007, p. 75-88.

BERSCH, R. Tecnologia assistiva e educação inclusiva. In: Ministério da Educação/Secretaria da Educação Especial (Org.). III Seminário Nacional de formação de Gestores e Educadores: Ensaios pedagógicos. Brasília, 2006. p. 281 - 286.

BERSCH, R.; MACHADO, R. Auxílio em atividades de vida diária: material escolar e pedagógico adaptado. In: SHIRMER, C. R. et al. Atendimento educacional especializado: deficiência física. Brasília SEESP/SEED/MEC. Brasília/DF. 2007. p. 41-53.

BRACIALLI et al. Influencia do assento da cadeira adaptada na execução de uma tarefa de manuseio. Revista Brasileira de Educação Especial. Marília: ABPEE, v. 1, n.14, p. 141 154, 2008. Quadrimestral.

BRACIALLI, L. M. P.; MANZINI, E. J.; AIRES, G. Mobiliário escolar adaptado para o deficiente físico: procedência, disponibilidade e critérios para utilização em classes especiais. In: MARQUEZINE, M. C. et al. (Org.). Educação física, atividades motoras e lúdicas, e acessibilidade de pessoas com necessidades especiais. Londrina: Eduel, 2003. p. 193-204.

BRACIALLI, L. M. P.; MANZINI, E. J.; REGANHAN, W. Contribuição de um programa de jogos e brincadeiras adaptadas para a estimulação de habilidades motoras em alunos com deficiência física. Temas sobre desenvolvimento, v. 13, n.77, p.7-46, 2004.

BRACIALLI, L. M. P.; MANZINI, E. J.; VILARTA, R. Influencia do mobiliário adaptado na variação angular da curvatura lombar de indivíduos com paralisia cerebral espástica.

Fisioterapia Brasil, v. 6, n.2, p.1142-1146, 2005.

BRASIL. Ministério da educação e cultura. Material pedagógico: manual de utilização. Rio de Janeiro: MEC/CENESP/FENAME/APAE de São Paulo, 1980. p. 410 - 445.

Declaração de salamanca e linha de ação sobre necessidades educativas especiais. Brasília: Corde, 1994.

Lei 9.394/96, de 20 de dezembro de 1996. Estabelece as diretrizes e bases da educação nacional. Diário Oficial [da] República Federativa do Brasil. Brasília, D. F., 31 de dez. de 1996. 
- Ministério da Educação - Secretaria da Educação Fundamental. Parâmetros curriculares nacionais: introdução aos parâmetros curriculares nacionais. 2. ed. Rio de Janeiro: DP\&A, 2000.

. Decreto n. 6094, de 24 de abril de 2007. Dispõe sobre a implementação do plano de metas e compromissos: todos pela educação. Brasília, 2007.

. Associação Brasileira de Normas Técnicas. NBR 9050: acessibilidade a edificações, mobiliários, espaços e equipamentos urbanos. Rio de Janeiro: ABNT, 2004. Disponível em: $<$ HTTP:// www.mj.gov.br/sedh/at/CORDE/ dpdh/corde/ABNT/NBR9050.31052004.pdf $>$. Acesso em: 11 jul. 2008.

. Política nacional da educação em uma perspectiva da educação inclusiva. Documento elaborado pelo Grupo de Trabalho nomeado pela Portaria $n^{\circ} 555 / 2007$, prorrogada pela Portaria $n^{\circ}$ 948/2007, entregue ao Ministro da Educação em 07 de janeiro de 2008. Disponível em: $<$ http://portal.mec.gov.br/arquivos/pdf/politicaeducespecial.pdf $>$. Acesso em: 20 mar. 2009.

BRASILEIRO, J.C.; MOREIRA, T. M. M.; JORGE, M. S. B. Interferência dos fatores ambientais na vida de crianças com paralisia cerebral. Revista Acta Fisiátrica, n. 16 (3); p.132-137, 2009.

BRUNO; M. M. G. Avaliação educacional de alunos com baixa visão e múltipla deficiência na educação infantil: uma proposta de adaptação e elaboração de instrumentos. 2005. 157f. v.2.Tese (Doutorado em Educação) - Faculdade de Filosofia e Ciências, Universidade Estadual Paulista, 2005.

BUNCHAFT, G.; CAVAS, C. S. T. Sob medida: um guia sobre a elaboração de medidas do comportamento e suas aplicações. São Paulo: Vetor, 2002.

CACCIARI, F. R.; DE LIMA, F. T.; BERNARDI, M. R. Ressignificando a prática: um caminho para a inclusão. Construção psicopedagógica. São Paulo, v 13; n. 10, p. 2005. Disponível em: http://ressignificandoaprática-bb/um caminho para a inclusão-b.mht $>$. Acesso em: 15 out. 2009.

CALVIÑO, M. Tipos de Organización funcional para El trabajo grupal. Revista Educación: una revista cubana que hace esencia de pensamiento. Cuba: Ciência Y Vitalidad, n. 94, mayoagosto, p. $2-7,1998$.

CAPOVILLA, A. G. S.; CAPOVILLA; F. C. Problemas de leitura e escrita: como identificar, prevenir e remediar numa abordagem fônica. 2 ed. São Paulo: Memmon, 2000. 
CARDOSO, L. R.; SINISCALCHI, M. G. Aspectos neuroanatômicos e neurofisiológicos do processamento sensorial. In: MOURA, et al. (Org.). Fisioterapia: aspectos clínicos e práticos da reabilitação. 2 ed. São Paulo: Artes Médicas/ AACD, 2010. p. 675-678.

CARVALHO, R. E. Temas em educação especial. 2. ed. Rio de Janeiro: W V A ed., 2000.

CHAIKIN, L. E. Distúrbios da visão e disfunção visuo perceptiva. In: Umphred, d. A. Reabilitação Neurológica, Tradução de Eloisa Galluzzi dos Santos et al., 4 ed. Barueri: Manole, 2004. p. 865-899.

CONROY, M. A. et al. Classwide interventions: effective instruction makes a difference. Teaching Exceptional Children, v. 40, n. 6, p. 24-30, 2008.

COSTER, W. J. et al. School Function Assesment: user manual. San Antonio, Texas: Therapy Skill Builders, 1998.

CRUZ, D. M. C. Brincar é estimular? Preensão, função manual e sua estimulação em préescolares com paralisia cerebral do tipo hemiparesia espástica. 2006. 152f. Dissertação (Mestrado em Educação Especial) - Universidade Federal de São Carlos, São Carlos, 2006.

CURTO, L. M.; MORILLO, M. M.; FEIXIDÓ, M. M. Escrever e ler: como as crianças aprendem e como o professor pode ensiná-las a escrever e ler. Tradução: Ernani Rosa. Porto Alegre: Artmed, 2000.

DALMÁS, A. Planejamento participativo na escola: elaboração, acompanhamento e avaliação. 13 ed. Petrópolis: Rio de Janeiro, 2005.

DE PAULA, R. Desenvolvimento de um protocolo para avaliação de habilidades comunicativas de alunos não falantes em ambientes escolar. 2007. 148 f. Dissertação (Mestrado em educação) - Faculdade de Filosofia e Ciências, Universidade Estadual Paulista, Marília, 2007.

DELAGRACIA, J. D. Desenvolvimento de um protocolo para avaliação de habilidades comunicativas para alunos não falantes em situação familiar. 2007. 98f. Dissertação (Mestrado em educação) - Faculdade de Filosofia e Ciências, Universidade Estadual Paulista, Marília, 2007.

DELIBERATO, D. Acessibilidade comunicativa no contexto acadêmico. In: MANZINI, E. J. (Org.). Inclusão do aluno com deficiência na escola: os desafios continuam. Marília: ABPEE/FAPESP, 2007. p. 25-36. 
DEMATTEO, C. et al. Quality of upper extremity skills test (QUEST). Hamilton: Mc Master University, Neurodevelopmental Clinical Research Unit. 1992. Disponível em: <www.canchild.ca/default.aspx?tabid=205-86k>. Acesso em: 16 jul. 2008.

DORETTO, D. Fisiopatologia clínica do sistema nervoso: fundamentos da semiologia. 2 ed. São Paulo: Atheneu, 2005.

DUTRA, C. P. Políticas públicas de inclusão e o papel da educação especial. In: MANZINI, E. J. (Org.). Inclusão e Acessibilidade. Marília: APPEE. 2006. p. 67 - 76.

FALVEY, M. A.; GIVNER, C. C.; KIMM, C. O que eu farei segunda-feira pela manhã? In: STAINBACK, S.; STAINBACK, W. Inclusão: um guia para educadores. Tradução de Magda França Lopes. Porto Alegre: Artes Médicas Sul, 1999. p. 142 -168.

FERREIRA, A. B. H. Novo dicionário eletrônico Aurélio versão 5.0. São Paulo: Positivo Informática LTDA, 2004.

FIGUEIREDO, C. A. V.; MANZINI, E. J. O recurso pedagógico sob o ponto de vista do aluno da habilitação do curso de pedagogia. Revista Brasileira de Educação Especial. Marília: ABPEE, n.8, v. 2, p. 183 - 204, 2002. Quadrimestral.

GALLAHUE, D. L.; OSMUN, J. Compreendendo o desenvolvimento motor: bebês, crianças, adolescentes e adultos. 3 ed. Tradução: Maria Aparecida da Silva Pereira Araújo, Juliana de Medeiros Ribeiro, Juliana Pinheiro Souza e Silva, São Paulo: Phorte, 2005.

GARCIA, S. C; DE ROSE, T. M. S. Rendimento acadêmico e adaptação escolar de alunos participantes na modalidade inclusiva de ensino que combina sala regular e salas de recursos. Revista Brasileira de Educação Especial. Marília: ABPEE, n.10, v. 1, p. 1 - 14, 2004. Quadrimestral.

GAUZZI, L. D. V; FONSECA, L. F. Classificação da paralisia cerebral. In: LIMA; C. L. A.; FONSECA, L. F. Paralisia cerebral: neurologia, ortopedia e reabilitação. Rio de Janeiro: Guanabara koogan, 2004. p. 37 - 44.

GIANNI, M. A. Paralisia cerebral. In: TEIXEIRA, E. et al. Terapia Ocupacional na reabilitação física. São Paulo: Roca, 2003. p. 89-100.

. Paralisia cerebral: aspectos clínicos. In: MOURA, et al. (Org.). Fisioterapia: aspectos clínicos e práticos da reabilitação. 2 ed. São Paulo: Artes Médicas/ AACD, 2010. p. $13-25$. 
GLAT, R.; KADLEC, V. P. S. A criança e suas deficiências: métodos e técnicas de atuação psicopedagógica. Rio de Janeiro: Agir, 1984.

GLENNEN, S. L. Augmentative and alternative communication systems. In: GLENNEN, S. L.; DE COSTE, D. C. Handbook of augmentative and alternative communication. São Diego: Singular Theomson Learning, 1996. p. 59-96.

GODOI, A. M. Trabalho escolar com crianças portadoras de paralisia cerebral. In: SOUZA, A. M. C.; FERRORETTO, I. (Org.). Paralisia cerebral: aspectos práticos. São Paulo: Memnon, 2001. p. $351-355$.

GONÇALVES, A. K. S. Estratégias pedagógicas inclusivas para crianças com paralisia cerebral na educação infantil. 2006. 136f. Dissertação (Mestrado em Educação) Universidade Federal de São Carlos, São Carlos, 2006.

GONZÁLEZ, J. A. T. Educação e diversidade: bases didáticas e Organizativas. Tradução de Ernani Rosa. Porto Alegre: Artmed, 2002.

GOYOS, C.; ALMEIDA, J. C. B. Mestre. Computer software. São Carlos, 1994.

GUIJARRO, M. R. B. Inclusão: um desafio para os sistemas educacionais. In: Ministério da Educação/Secretaria da Educação Especial (Org.). Ensaios pedagógicos: construindo escolas inclusivas, Brasília, p. 7 - 14, 2005.

GUSMAN, S.; TORRE, C. A. Fisioterapia em paralisia cerebral. In: SOUZA, A. M. C.; FERRARETTO, I. Paralisia Cerebral: aspectos práticos. 2. ed. São Paulo: Memnon, 2001. p. 169 - 206.

HELFER, I. C.; OLIVEIRA, R. D.; MIOSSO, S. M. P. O brincar e a realidade de aprendizagem da criança com deficiência física decorrente da paralisia cerebral. Arquivos Brasileiros de Paralisia Cerebral, v.1(2). Mennon: edições científicas, p. 26-35, 2005. Quadrimestral

HOUAISS, A. Dicionário Hoauiss da Língua Portuguesa. 3008f. São Paulo: Objetiva, 2001.

IMAMURA, E. T. Formação continuada do professor para uso de recurso de informática com alunos com deficiências físicas. 2008. 161 f. Dissertação (Mestrado em educação) Faculdade de Filosofia e Ciências, Universidade Estadual Paulista, Marília, 2008. 
LAMÔNICA, D. A. C.; CHIARI, B. M.; PEREIRA, L. D. Perda auditiva em indivíduos paralíticos cerebrais: discussão etiológica. Revista Brasileira Otorrinolaringol, v. 68, n.1, janfev, p. 40-44, 2002. Disponível em: <http: // www. sborl.Org..br>. Acesso em: 19 out. 2009.

LOURENÇO, G. F. Protocolo para avaliar a acessibilidade ao computador para alunos com paralisia cerebral. 2008. 212 f. Dissertação (Mestrado em educação especial) Universidade Federal de São Carlos (UFSCar), São Carlos, 2008.

MAGALHÃES, L. C.; LAMBERTUCCI, M. C. F. Integração sensorial na criança com paralisia cerebral. In: LIMA; C. L. A.; FONSECA, L. F. Paralisia cerebral: neurologia, ortopedia e reabilitação. Rio de Janeiro: Guanabara koogan, 2004. p. 299 - 309.

MANZINI, E. J. Recurso pedagógico adaptado e estratégias para o ensino de alunos com deficiência fisica. 20 f. no prelo. 1990/1991.

A entrevista na pesquisa social. Didática, São Paulo, v. 26/27, p. 149-158,

Recursos pedagógicos para o ensino de alunos com paralisia cerebral. Revista Mensagem da APAE, n.84, v. 36, p. 17-21,1999.

. Avaliação educacional do aluno com necessidades especiais: enfocando o deficiente físico. In: OMOTE, S. (Org.). Boletim do COE (Faculdade de Filosofia e Ciências - UNESP). Marília: UNESP Publicações, n. 5, p. 91-105, nov. 2000a.

Análise de tarefa: procedimento indicado para ensino do aluno com deficiência física. In: OMOTE, S. (Org.). Boletim do COE (Faculdade de Filosofia e Ciências - UNESP). Marília: UNESP Publicações, n. 5, p. 113-118, nov. 2000b.

Dificuldades de comunicação de crianças com deficiência física: um procedimento para utilização da resposta sim ou não? In: OMOTE, S. (Org.). Boletim do COE (Faculdade de Filosofia e Ciências - UNESP). Marília: UNESP Publicações, v. 5, n. 5, p. 107-111, nov. 2000c.

Considerações sobre a elaboração de roteiro para entrevista semi-estruturada. In: MARQUESINE, M. C.; ALMEIDA, M. A.; OMOTE, S. (Org.). Colóquios sobre pesquisa em Educação Especial. Londrina: Eduel, 2003. p. 11-25. 
. Tecnologia assistiva para educação: recursos pedagógicos adaptados. Ministério da Educação/Secretaria da Educação Especial (Org.). Ensaios pedagógicos: construindo escolas inclusivas, Brasília, p. $82-86,2005$.

MANZINI, E. J.; DELIBERATO, D. Comunicação alternativa aumentativa. In: MANZINI, E. J.; CAMPELLO, J. E. (Org.). Educação Especial. São Luís: Imprensa Universitária, (Coleção Prata da Casa, 6),1999. p. 95-103.

Portal de ajudas técnicas: equipamento e material pedagógico especial para educação, capacitação e recreação da pessoa com deficiência física - recursos para comunicação alternativa. Brasília: MEC/SEESP, 2004. fascículo 2.

. Portal de ajudas técnicas para educação: equipamento e material pedagógico para educação, capacitação e recreação da pessoa com deficiência física: recursos pedagógicos adaptados II. Brasília: ABPEE-MEC: SEESP, 2007. fascículo 4.

MANZINI, E. J.; SANTOS, M. C. F. Portal de ajudas técnicas para educação: equipamento e material pedagógico para educação, capacitação e recreação da pessoa com deficiência física: recursos pedagógicos adaptados. Brasília: MEC: SEESP, 2002. fascículo 1.

MARTÍN, M. C.; JÁUREGUI M. V. G.; LÓPEZ, M. L. S. Incapacidade motora: orientações para adaptar a escola. Tradução de Fátima Murad. Porto Alegre: Artmed, 2004.

MARTINS, L. A. R. Formação de professores numa perspectiva inclusiva: algumas constatações. In: MANZINI, E. J. (Org.). Inclusão e Acessibilidade, Marília: ABPEE, 2006. p. $17-28$.

MARUJO, V. L. M. B. Fonoaudiologia em Paralisia Cerebral. In: SOUZA, A. M. C. de; FERRORETO, I. Paralisia cerebral: aspectos práticos. 2 ed. São Paulo: Frontis Editorial, 2001. p. 207-230.

MELLO, M. I. T. Concepções acerca da deficiência física: estudo realizado com uma comunidade escolar. 1999. 96 f. Dissertação (Mestrado em Pós Graduação Em Educação) Universidade Estadual Paulista Júlio de Mesquita Filho.

MELO, F. R. L. V.; MARTINS, L. A. R. O que pensa a comunidade escolar sobre o aluno com paralisia cerebral.Revista Brasileira de Educação Especial, Marília: ABPEE; n.1, v.10, p. 15-92, 2004. Quadrimestral. 
Acolhendo e atuando com alunos que apresentam paralisia cerebral na classe regular: a organização da escola. Revista Brasileira de Educação Especial, Marília: ABPEE; n.1, v.13, p. 111-130, 2007. Quadrimestral.

MÉLO, T. R. Avaliação da sensibilidade em mãos de crianças portadoras de paralisia cerebral do tipo diplegia em idade escolar. 2004, 80f. Monografia do curso de fisioterapia, UNIOESTE, Cascavel, 2004.

MENDES, E. G. Colaboração entre ensino regular e especial: o caminho do desenvolvimento pessoal para a inclusão escolar. In: MANZINI, E. J. (Org.). Inclusão e Acessibilidade.

Marília: APPEE, 2006. p. 29 - 42.

MILLER, G.; CLARK, G. D. Paralisia cerebral: causas, conseqüências e conduta. São Paulo: Manole, 2002.

MILLIKIN, C. C. Symbol systems and vocabulary selection strategies. In: GLENNEN, S. L.; DE COSTE, D. C. Handbook of augmentative and alternative communication. São Diego: Singular Theomson Learning, 1996. p. 97-148.

MIRABELLI-SUSENS, L. Gerenciamento da dor. In: UMPHRED, D. A. Reabilitação Neurológica. 4 ed. São Paulo: Manole, 2004. p. 936-961.

MORO, A. R. P. Análise do sujeito na postura sentada em três diferentes situações de mobiliário cadeira-mesa simulado em um protótipo. Revista Eletrônica do Estudo do Movimento Humano (Kinein), v. 1, n 1, set-dez, p.1/1, 2000.

MOURA, M. J. Inclusão e escolaridade. In: LIMA, C. L. A.; FONSECA, L. F. Paralisia cerebral. Rio de Janeiro: MEDSI Guanabara, 2004. p. 399-412.

NUNES, A. M. S. O perfil do cuidador da criança portadora de Paralisia Cerebral. Revista Meio Ambiente Saúde; v. 2 (1), p. 1-21, 2007.

NUNES, A. L. R.; LEMOS, H. D. D.; MENDES, C. R. O papel do jogo no processo de inclusão de crianças com necessidades educacionais especiais: alternativas no cotidiano escolar. Revista Ponto de Vista, Florianópolis, n.8, p. 31-54, 2006.

OLIVEIRA, M. C. Avaliação da sensibilidade, função motora de membros superiores e desempenho funcional de crianças portadoras de paralisia cerebral. 2007, 181f. Dissertação (Mestrado) - Universidade Estadual de Campinas. Faculdade de Ciências Médicas, Campinas, 2007. 
OMOTE, S. Inclusão: da intenção à realidade. In: OMOTE, S. (Org.). Inclusão: intenção e realidade, Marília: Fundepe, 2004. p. 1 - 10.

OMOTE, S. et al. Mudança de atitudes sociais em relação à inclusão. Paidéia, v. 15 (32), p. 387-398, 2005.

PADILHA, A. M. L. Práticas pedagógicas e a inserção sócio-cultural do deficiente: a complexidade da proposta. In: MANZINI, E. J. (Org.). Inclusão e Acessibilidade. Marília: APPEE, 2006. p. $43-50$.

PAIVA, P. C. Influência da textura do recurso pedagógico em atividade de encaixe realizada por alunos com paralisia cerebral. 2007. 104f. Dissertação (Mestrado em educação) Faculdade de Filosofia e Ciências, Universidade Estadual Paulista, Marília, 2007.

PELOSI, M. B. Por uma escola que ensine e não apenas acolha recursos e estratégias para inclusão escolar. In: MANZINI, E. J. (Org.). Inclusão e Acessibilidade. Marília: APPEE. 2006. p. $121-132$.

PEREIRA, D. B. Terapia Ocupacional em Paralisia Cerebral Atetóide e Atáxica. In: SOUZA, A. M. C.; FERRARETTO, I. Paralisia Cerebral: aspectos práticos. 2 ed, São Paulo: Memnon, 2001. p. $243-250$.

POLLOCK, N. et al. The Mac Master: handwriting assessment protocol. School of Rehabilitation Science: Mc Master University, 2008. Disponível em: $<$ www.canchild.ca/default.aspx?tabid=205-86k>. Acesso em: 16 jul. 2008.

RADELL, U. Augmentative and alternative communication assessment strategies: seating and positioning. In: GLENNEN, S. L.; DE COSTE, D. C. (Org.). Handbook of augmentative and alternative communication. San Diego London: Singular Theomson Learning, 1996. p. 193 242.

RAMOS, A. S.; ALVES, L. M. A fonoaudiologia na relação entre escolas regulares de ensino fundamental e escolas de educação especial no processo de inclusão. Revista Brasileira de Educação Especial. Marília: ABPEE, v.14, n 2, p. 235 - 250, 2008. Quadrimestral.

RAVAZZI, L.; GOMES, N. M. A inclusão de alunos com paralisia cerebral nas aulas de educação física. In: V Congresso Brasileiro Multidisciplinar de Educação Especial, 2009, Londrina. Anais do V Congresso Brasileiro Multidisciplinar de Educação Especial. Londrina: UEL, 2009. p. 273-278. 
REAL, L. M.; PARKER, R. A. Metodologia de pesquisa: do planejamento a execução. Tradução de Nivaldo Montingelli Jr. São Paulo: Pioneira, 2000.

REGANHAN, W. G. Recursos e estratégias para o ensino de aluno com deficiência: percepção de professores. 2006. 216f. Dissertação (Mestrado em Educação) - Faculdade de Filosofia e Ciências, Universidade Estadual Paulista, Marília, 2006.

REGANHAN, W. G.; MANZINI, E. J. Percepção de professores do ensino regular sobre recursos e estratégias para o ensino de alunos com deficiência. Revista Educação Especial, Santa Maria, v. 22, n 34, p.127-138, 2009. Disponível em:

$<$ http://www.ufsmbr/revistaeducacaoespecial> Acesso em: 12 nov. 2009.

ROCHA, A. N. D. C.; DELIBERATO, D. A tecnologia assistiva como instrumento facilitador da inclusão escolar de alunos com deficiência física. In: V Congresso Brasileiro Multidisciplinar de Educação Especial, 2009, Londrina. Anais do V Congresso Brasileiro Multidisciplinar de Educação Especial. Londrina: UEL, 2009, p. 500-509.

SAMESHIMA, F. S. Habilidade Expressiva de um grupo de alunos não falantes durante as atividades de jogos. 2006. 135f. Dissertação (Mestrado em Educação) - Faculdade de Filosofia e Ciências, Universidade Estadual Paulista, Marília, 2006.

SAMESHIMA, F. S.; DELIBERATO, D. Identificação das habilidades expressivas utilizadas por um grupo de alunos não falantes durante atividades de jogos. In: MANZINI, E. J. (Org.). Inclusão do aluno com deficiência na escola: os desafios continuam. Marília:

ABPEE/FAPESP, 2007, p. 37 - 50.

SAMESHIMA, F. S.; RODRIGUES, I. B.; DELIBERATO, D. A parceria entre especialista, professor e família no processo de implementação da comunicação alternativa: uma condição necessária. In: V Congresso Brasileiro Multidisciplinar de Educação Especial, 2009, Londrina. Anais do V Congresso Brasileiro Multidisciplinar de Educação Especial. Londrina: UEL, 2009, p. 379-388.

SAMPAIO, M. J. T.; REIS, N. M. M. Utilização da informática na Paralisia Cerebral: possibilidades e recursos na clínica da terapia ocupacional. In: LIMA; C. L. A.; FONSECA, L. F. Paralisia cerebral: neurologia, ortopedia e reabilitação. Rio de Janeiro: Guanabara Koogan, 2004. p. $289-298$.

SANKAKO, A. N.; OLIVEIRA, F.T.; MANZINI, E. J. Protocolo para avaliação de habilidades motoras para adaptar recursos pedagógicos. In: MANZINI, E. J. (Org.). Inclusão do aluno com deficiência na escola: os desafios continuam. Marília: ABEPEE/FAPESP, 2007 , p. $139-152$. 
SANTOS, L. S. B. Adaptações na paralisia cerebral. In: SOUZA, A. M. C. de; FERRORETO, I. Paralisia cerebral: aspectos práticos. São Paulo: Frontis Editorial, 1998. p. 333-345.

SAURON, F. N. Órteses para membros superiores. In: SOUZA, A. M. C.; FERRARETTO, I. Paralisia Cerebral: aspectos práticos. 2 ed. São Paulo: Memnon, 2001. p. 127-134.

SCHIMITZ, E. F. Didática moderna: Fundamentos. 2 ed. Rio de Janeiro: Livros técnicos e científicos, 1980.

SCHWARTZWAN, J. S. Paralisia Cerebral. Arquivos Brasileiros de Paralisia Cerebral. São Paulo: Memnon, v.1(1), p. 5-17, 2004. Quadrimestral.

SHIRMER, C. R. et al. Atendimento educacional especializado: deficiência física. Formação continuada a distância de professores para o atendimento educacional especializado.

Brasília: SEESP/SEED/MEC, 2007.

SILVA, A. N. Estratégias de mediação em atividade de reconto de histórias com alunos não oralizados. 2008, 78f. Dissertação (Mestrado em Educação) - Faculdade de Filosofia e Ciências, Universidade Estadual Paulista, Marília, 2009a.

SILVA, D. B. R. Avaliação das atividades de crianças com paralisia cerebral na escola regular: participação, níveis de auxílio e desempenho. 2007, 116f. Dissertação (Mestrado em Educação Especial) - Universidade Federal de São Carlos, São Carlos, 2007.

SILVA, M. O. Um retrato da comunicação alternativa no Brasil: relatos de pesquisas e experiências. Revista Brasileira de Educação Especial, Marília: ABPEE, n.2, v.14, p. 327$328,2009 b$.

SILVA, M. O.; BRACIALLI, L. M. P.; MANZINI, E. J. Instrumentos de avaliação motora em crianças e adolescentes ( 0 a 16 anos) com paralisia cerebral. 32f. In: IV Seminário Nacional Promoção de inclusão mediada pelas tecnologias assistivas, Curitiba. Anais: Inclusão, acessibilidade e promoção humana. Curitiba: UTP/UEPA/UFBA, p. 27-28, 2009.

SILVA, M. T. M.; SANTOS, A. P. Análise descritiva da adequação do mobiliário escolar nas séries iniciais do ensino fundamental. Revista Roteiro, Joaçaba (RS), v 31, p. 123-134, 2008.

SMITH, M. A.; RYNDAK, D. L. Estratégias práticas para a comunicação com todos os alunos. In: STAINBACK, S.; STAINBACK, W. Inclusão: um guia para educadores. Tradução de Magda França Lopes. Porto Alegre: Artes Médicas Sul, 1999. p. 110-128. 
SOUZA, A. M. C. Definição de paralisia cerebral. Resenha de: International Workshop on Definiton and Classification of Cerebral Palsy. Bethesda, Mariland. Arquivos Brasileiros de Paralisia Cerebral, v.1(3). Mennon: edições científicas. p. 50-52, 2005. Quadrimestral.

SOUZA, D. M. C. Ampliação do repertório funcional de portadores de deficiência física. 2003, 100f. Dissertação (Mestrado em Educação Especial) - Universidade Federal de São Carlos, São Carlos, 2003.

SOUZA, P. A. Aspectos motivacionais na reabilitação da paralisia cerebral. In: LIMA; C. L. A.; FONSECA, L. F. Paralisia cerebral: neurologia, ortopedia e reabilitação. Rio de Janeiro: Guanabara Koogan, 2004. p. $211-219$.

SPOSITO, M. M. M.; FONSECA, A. P. C. Visão da fisiatria no tratamento da criança com paralisia cerebral. In: LIMA, C. L. A.; FONSECA, L. F. Paralisia cerebral. Rio de Janeiro: MEDSI Guanabara, 2004. p. 241-248.

STECKER, P. M; LEMBKE, E. S.; FOEGEN, A. Using progress-monitoring data to improve instructional decision making. Preventing School Failure, v. 52, n.2, Winter, 2008.

TABITH JÚNIOR, A. Foniatria: disfonias, fissuras, labiopalatais, paralisia cerebral. 7 ed. São Paulo: Cortez, 1995.

TALUSE, M. K. U. Oftalmologista em paralisia cerebral. In: SOUZA, A. M. C.; FERRORETO, I. Paralisia cerebral: aspectos práticos. 2 ed. São Paulo: Frontis Editorial, 2001. p. 135-147.

TEZANI, T. C. R. Os caminhos para a construção da escola inclusiva: a relação entre a gestão escolar e o processo de inclusão. 2004, 207f. Dissertação (Mestrado em Educação Especial) - Universidade Federal de São Carlos, São Carlos, 2004.

VYGOTSKY, L. S. A formação social da mente. Tradução José Cipolla Neto; Luis Silveira Menna Barreto; Solange Castro Afeche. 4 ed. São Paulo: Martins Fontes, 1991.

ZOPPA, A. C. L. Terapia Ocupacional em paralisia cerebral. In: SOUZA, A. M. C.; FERRORETTO, I. (Org.). Paralisia cerebral: aspectos práticos. 2 ed. São Paulo: Memnon, 2001. p. $231-242$.

WOSNY, A. M. et al. Estética dos odores: o sentido do olfato e a enfermagem. Rev. Latinoam enfermagem, v. 16 (2), p. 153-156, 2008. Disponível em: www.eerp.usp.br/rlae. Acesso em: 19 out. 2009. 
APÊNDICE A- GUIA PARA UTILIZAÇÃO DO INSTRUMENTO 


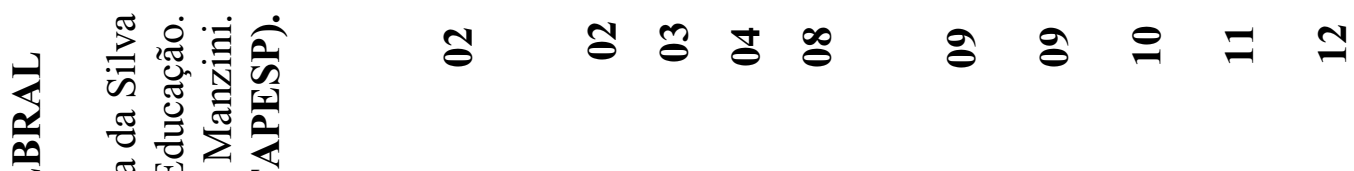

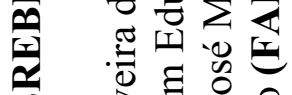

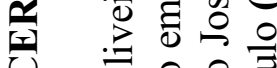

४

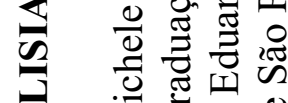

$\gtreqless \quad \sum \bigcup_{1}^{\circ}$

\&

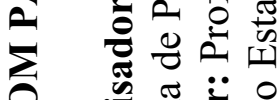

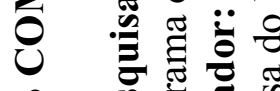

ช \&

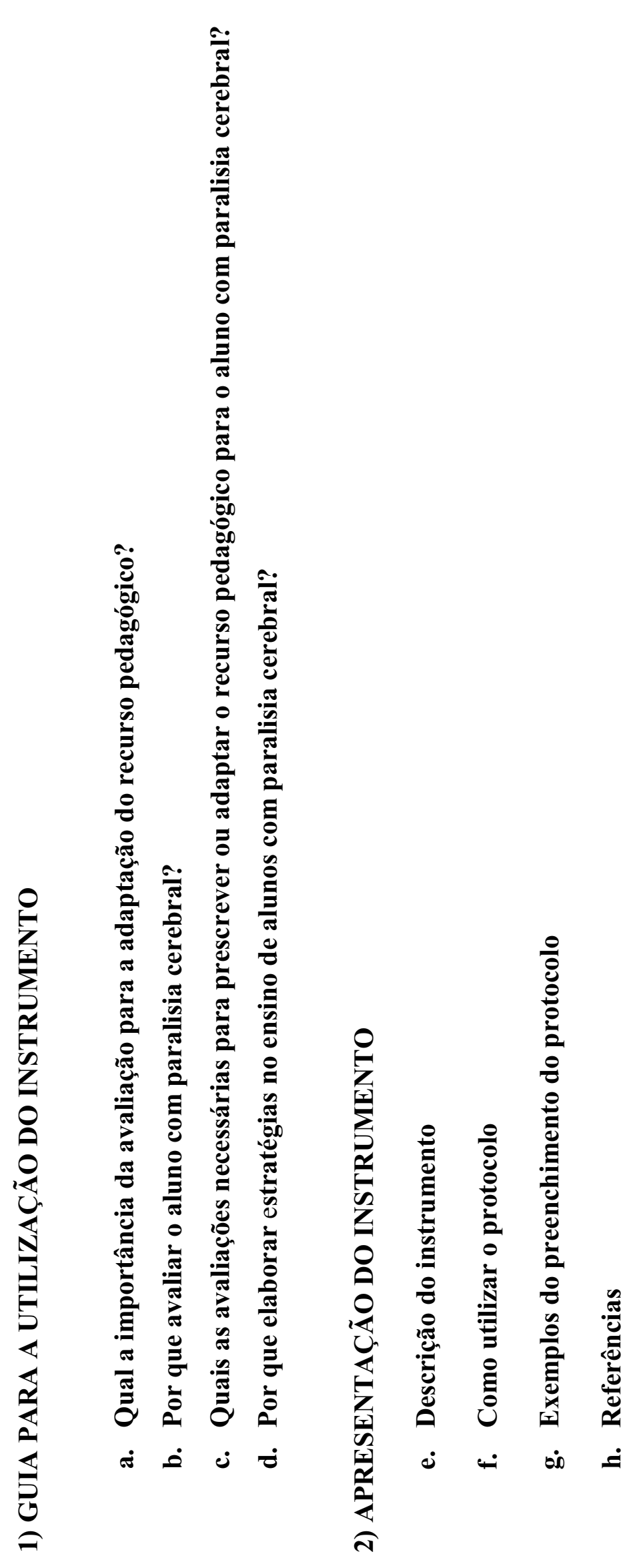

致

政

正

द

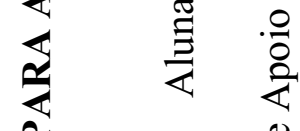

:

葛

8

莫

8

(8)

证

园

$\frac{\pi}{4}$

잉

3

क

ํ.

Tี

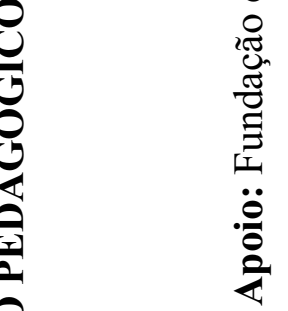




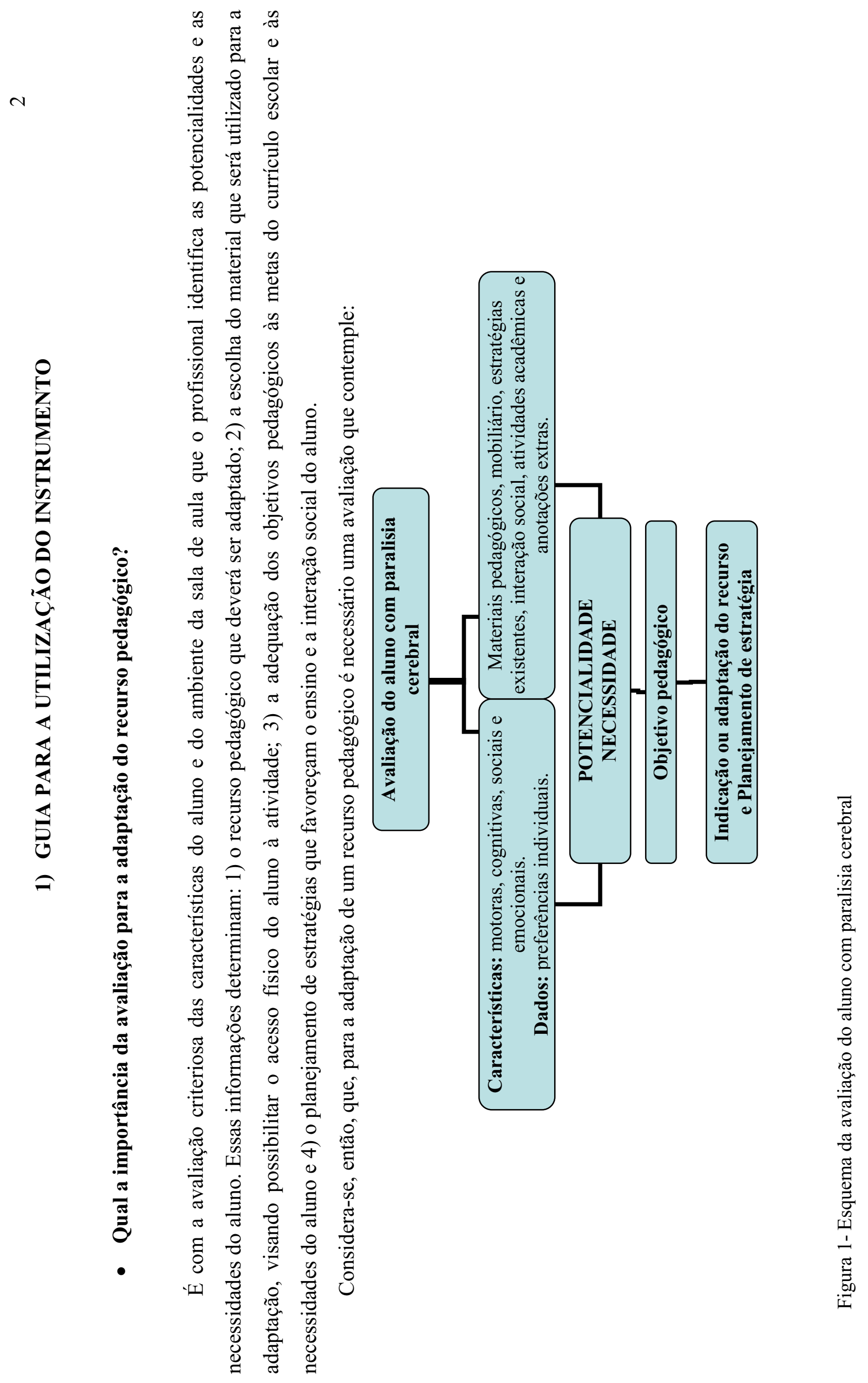




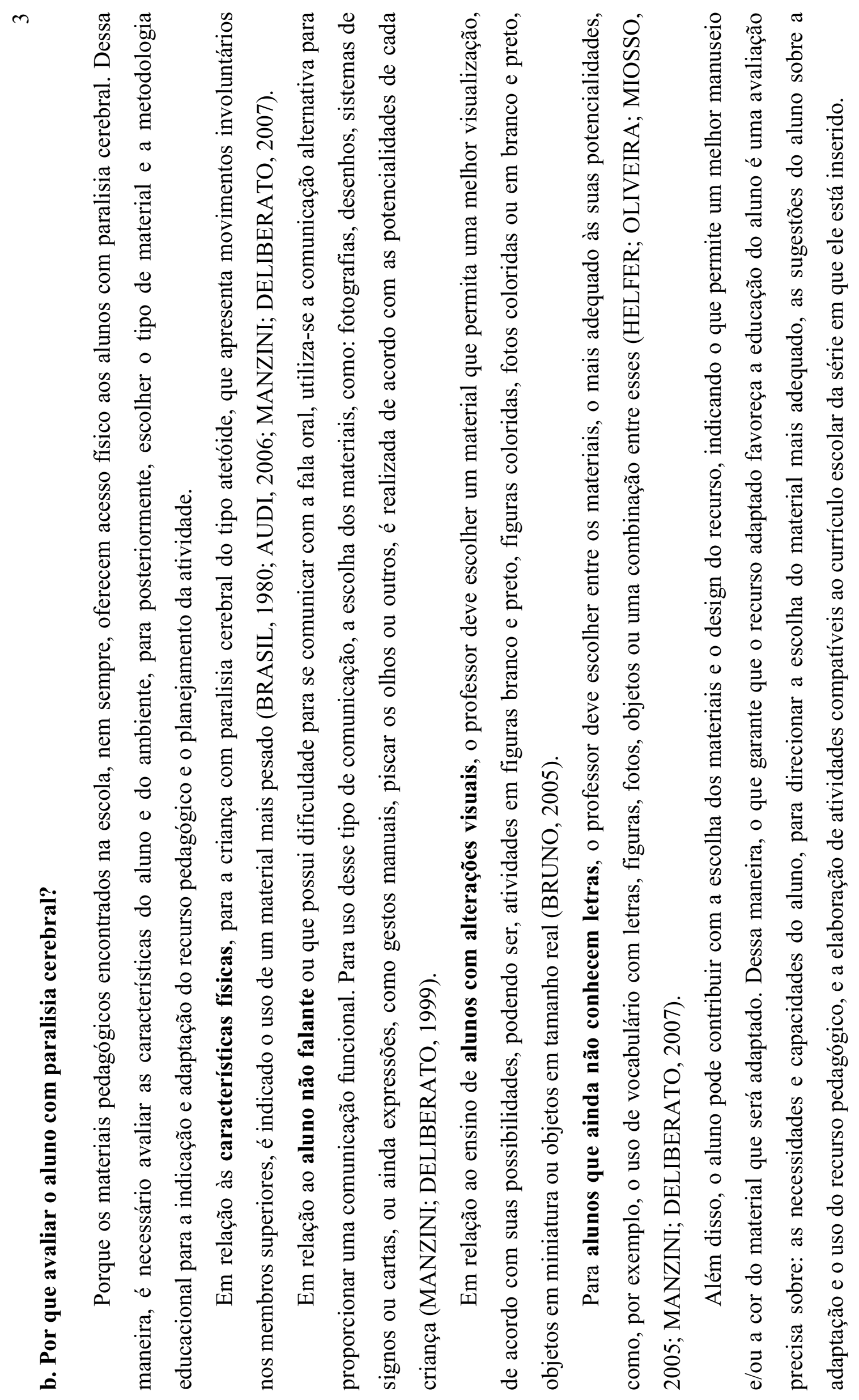




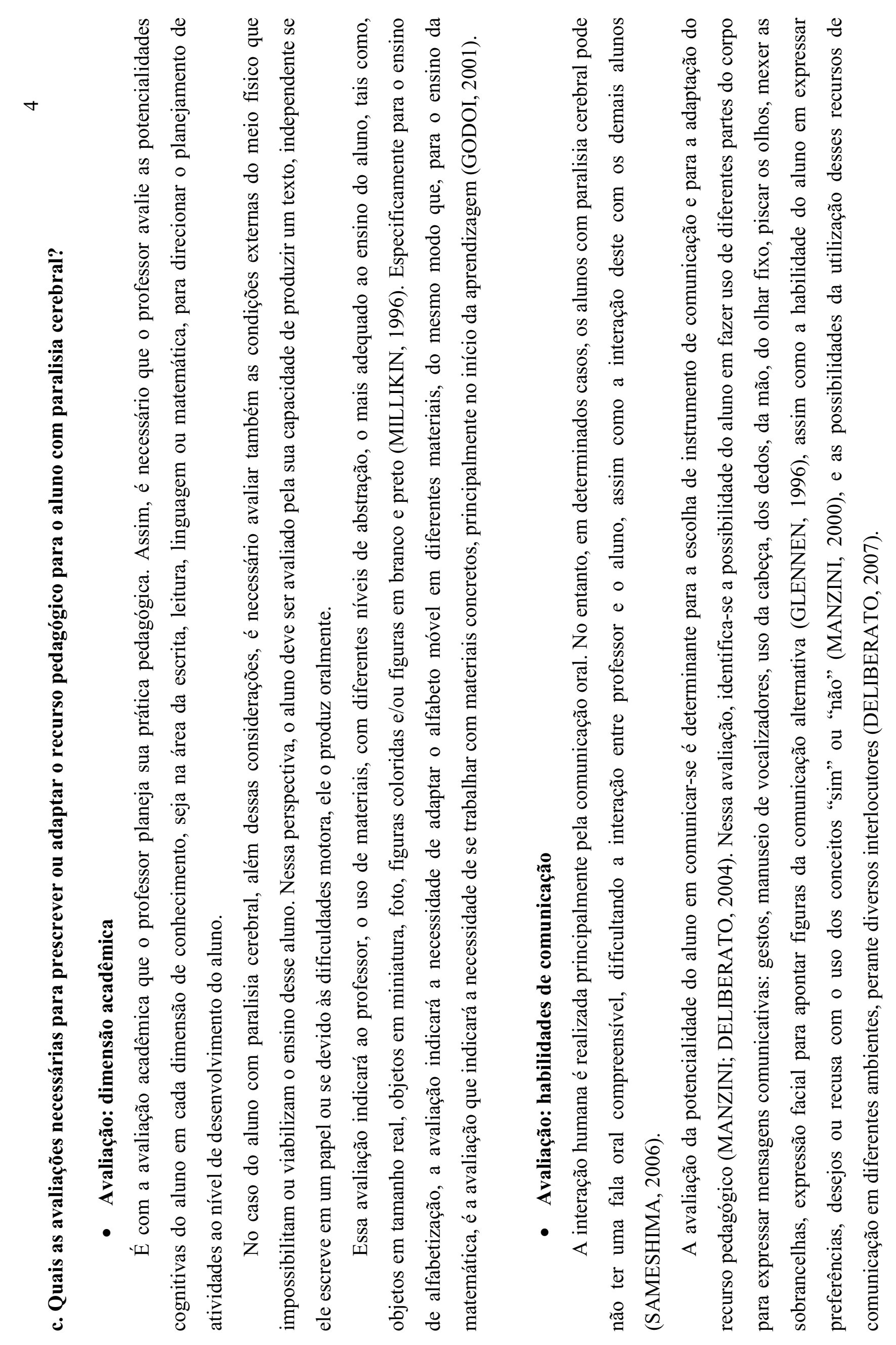




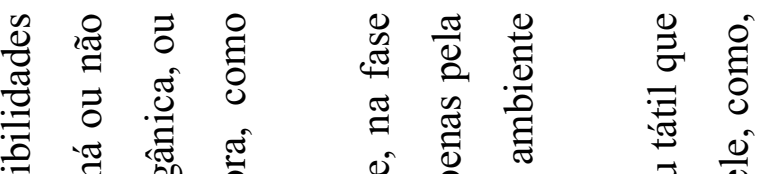

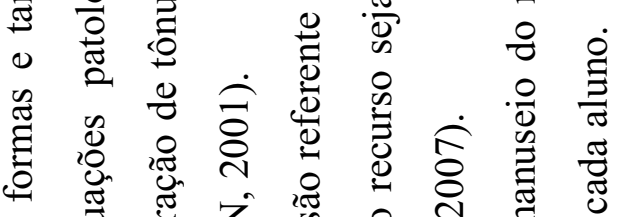

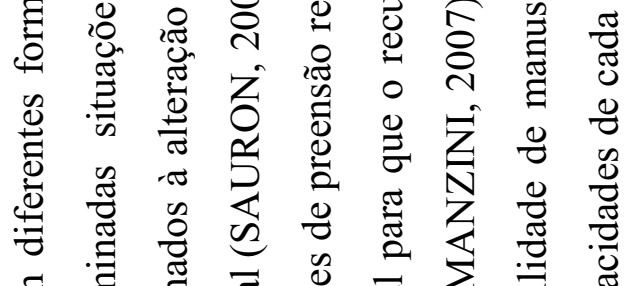

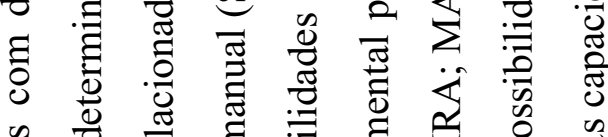

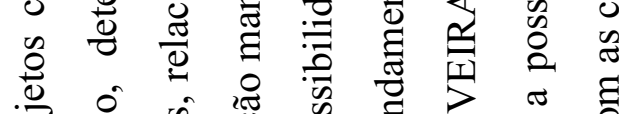

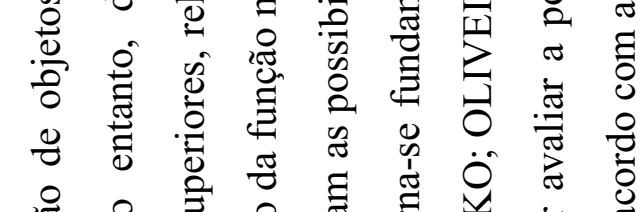

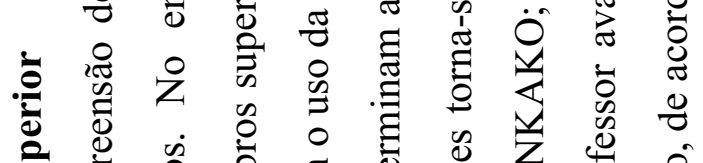

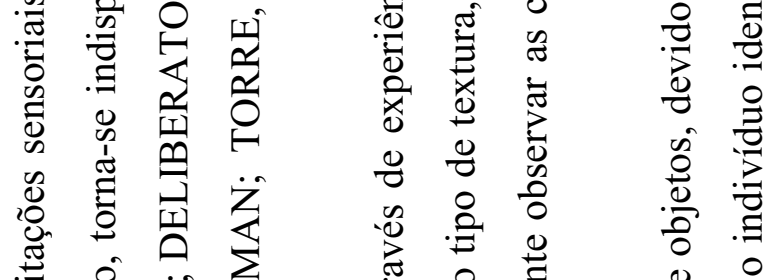

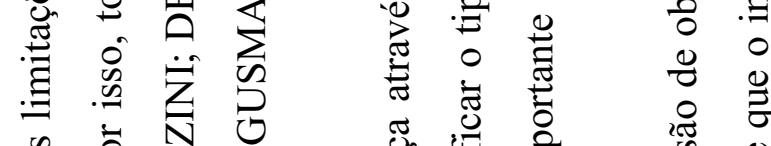

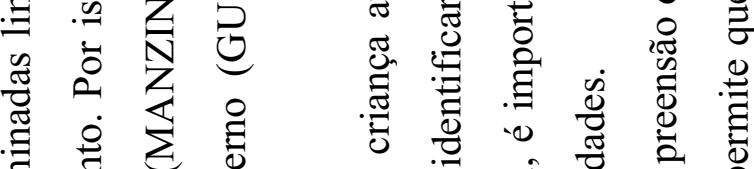

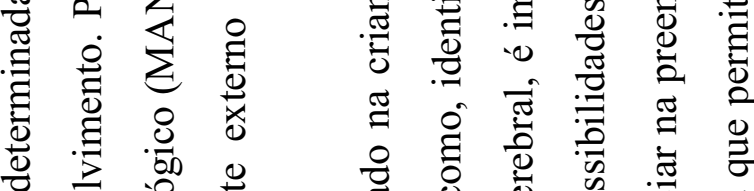

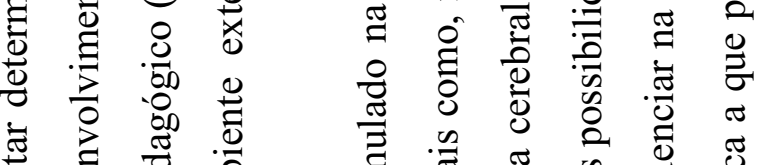

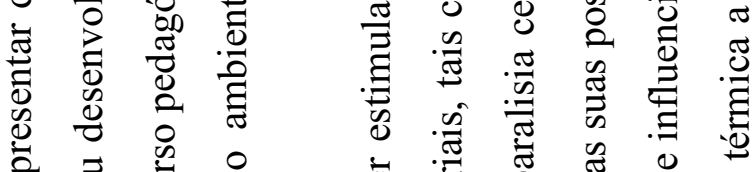

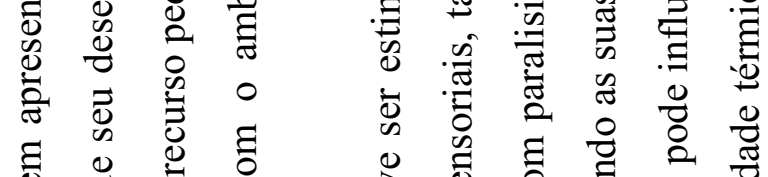

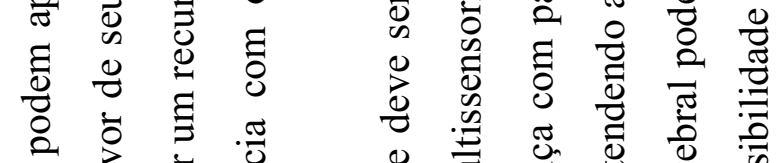

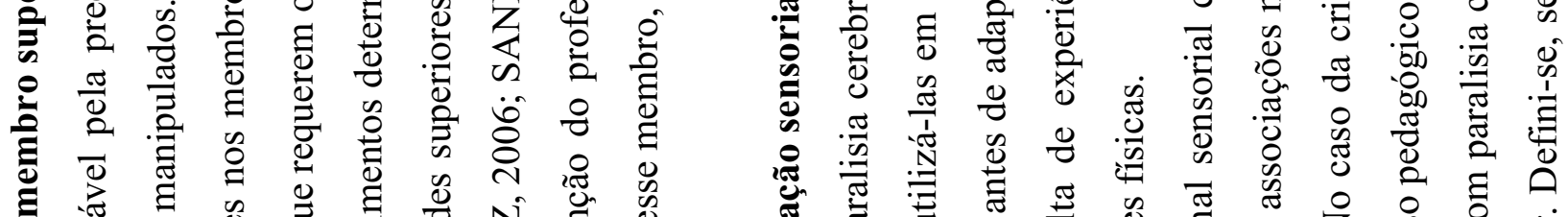
$\begin{array}{llll} & \\ 0\end{array}$

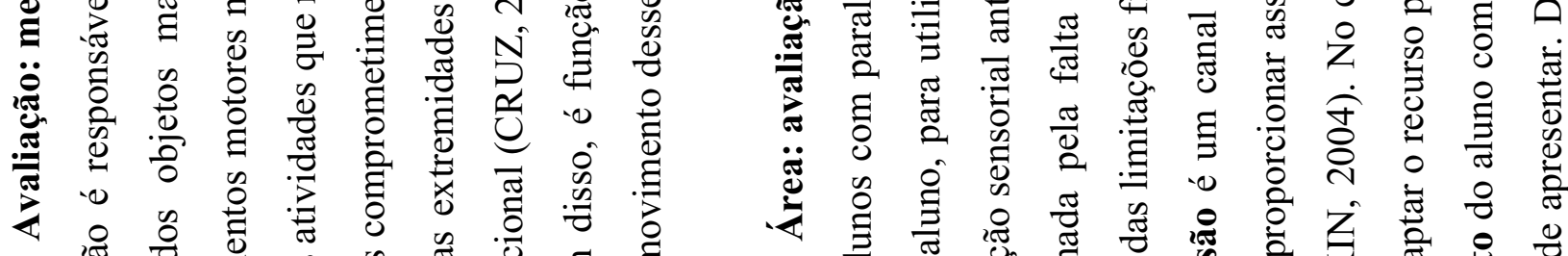

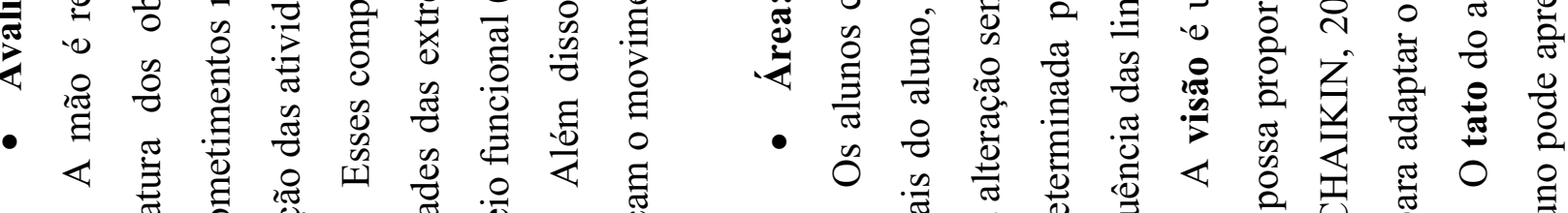
$\begin{array}{llll} & \\ 0\end{array}$ 


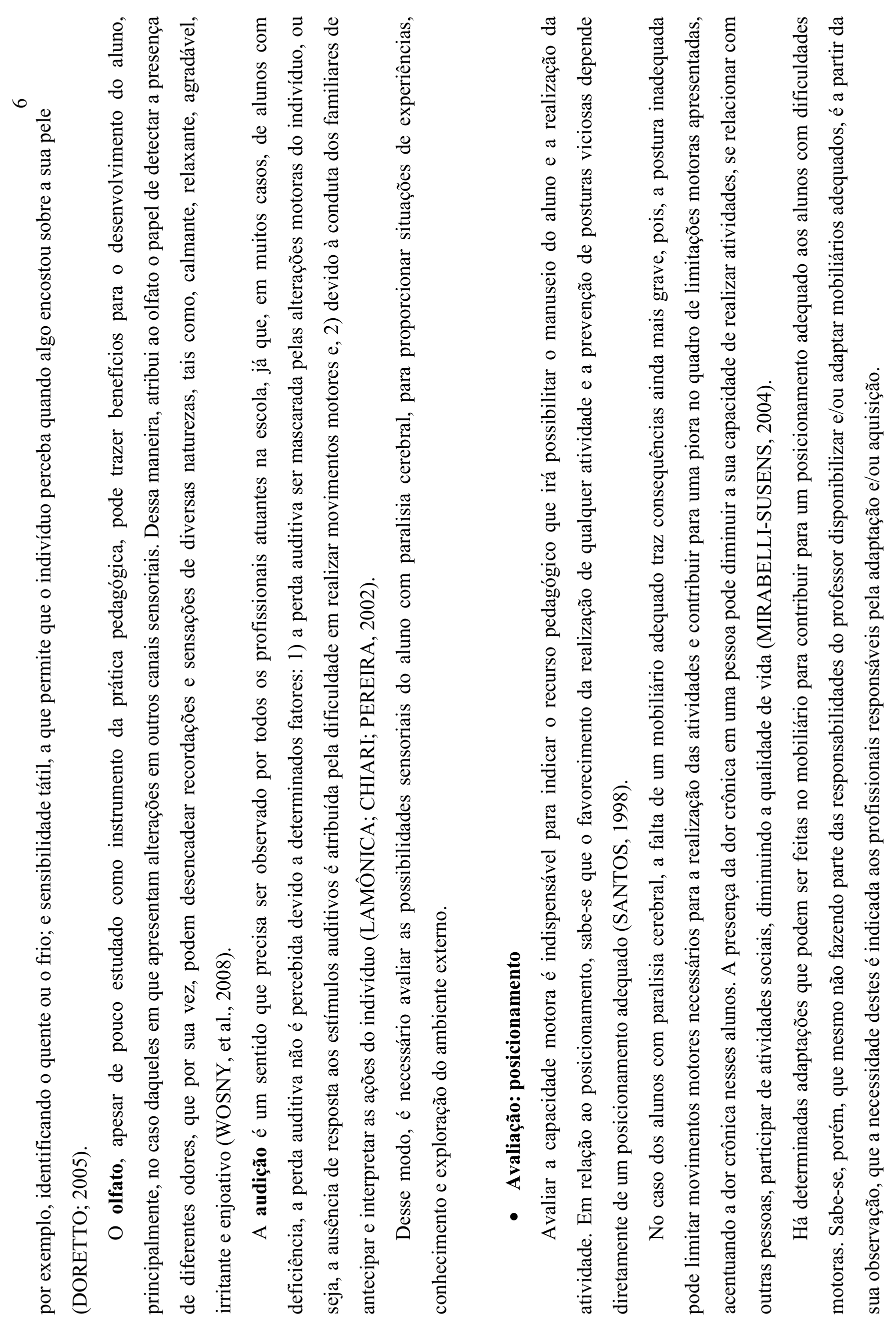




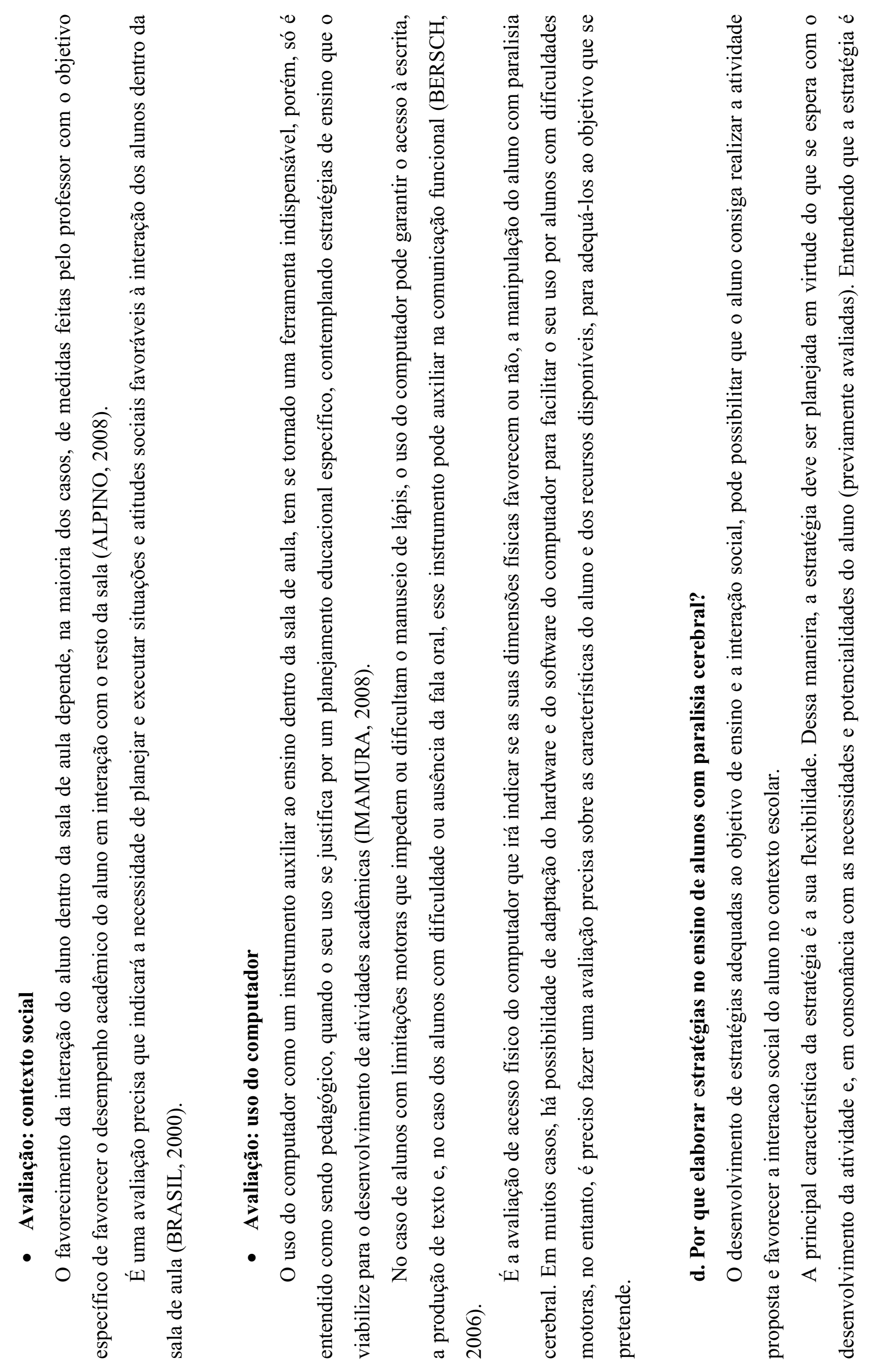




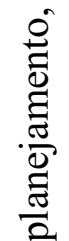

ప

○

蒈

팡

2:

.

ซิ

$\circ \pi$

ठั

.

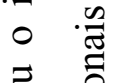

ప

感

की

츨 으

寻 :

过

응

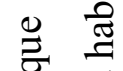

敢

क

糬 


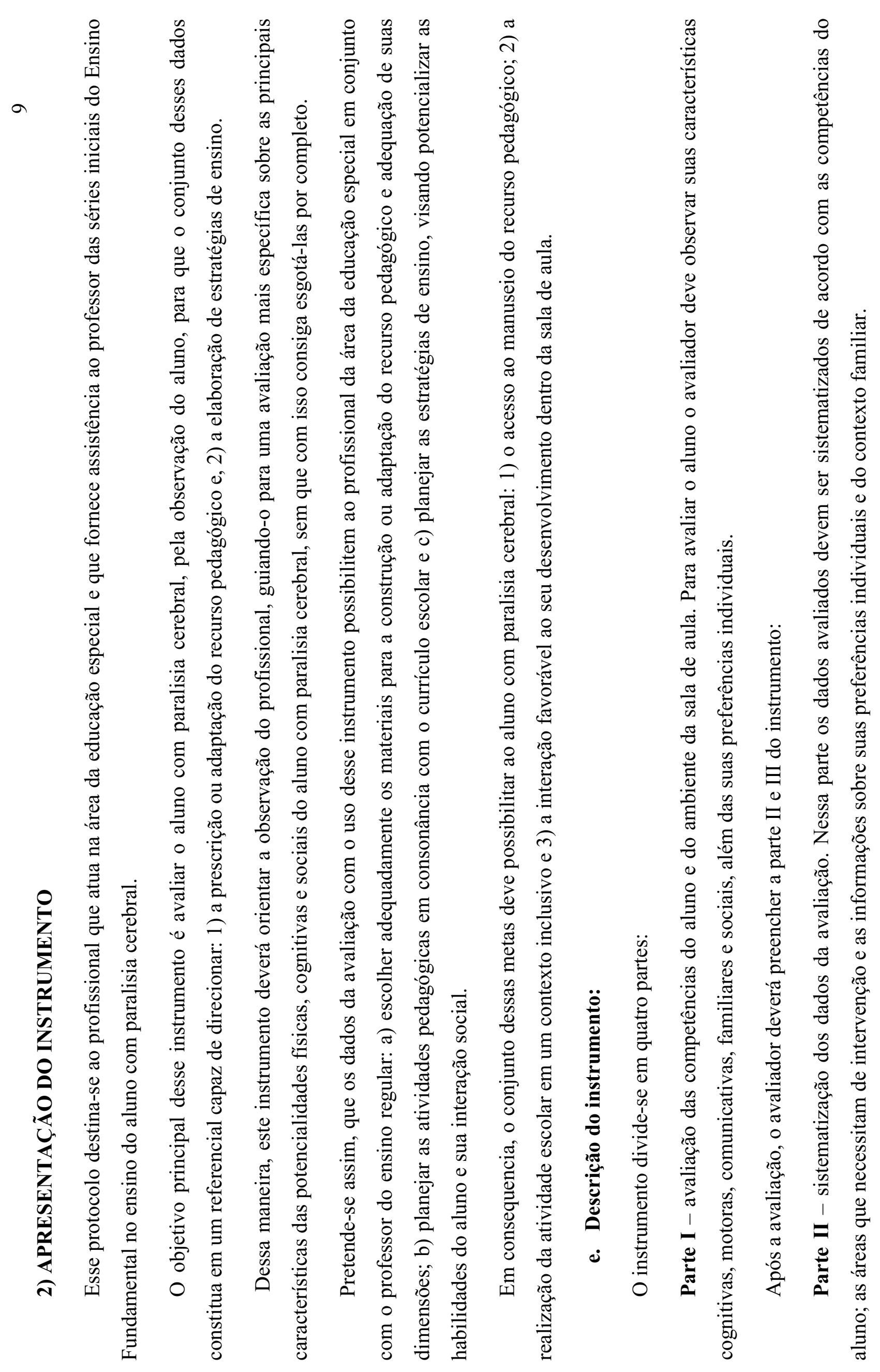




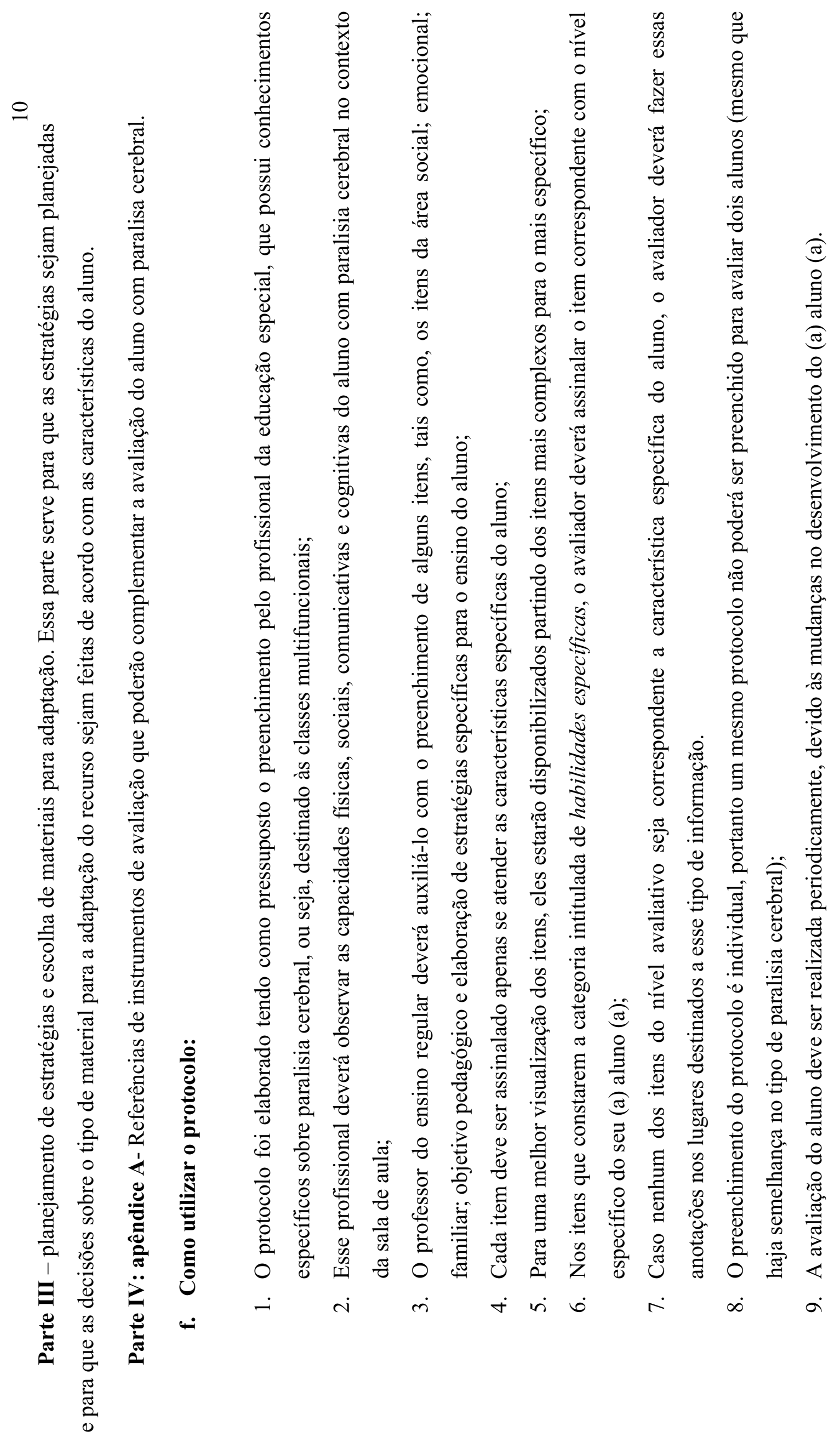




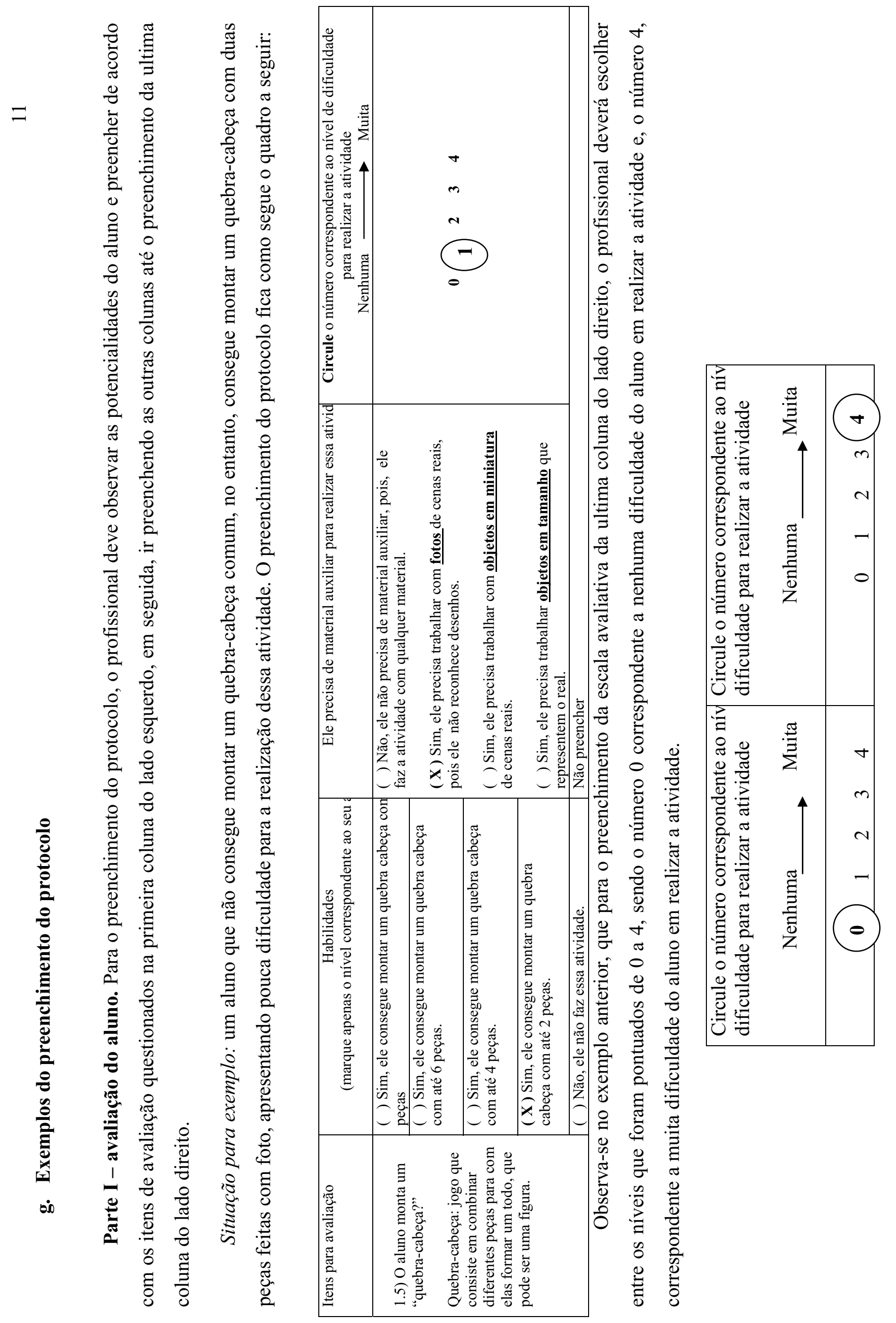




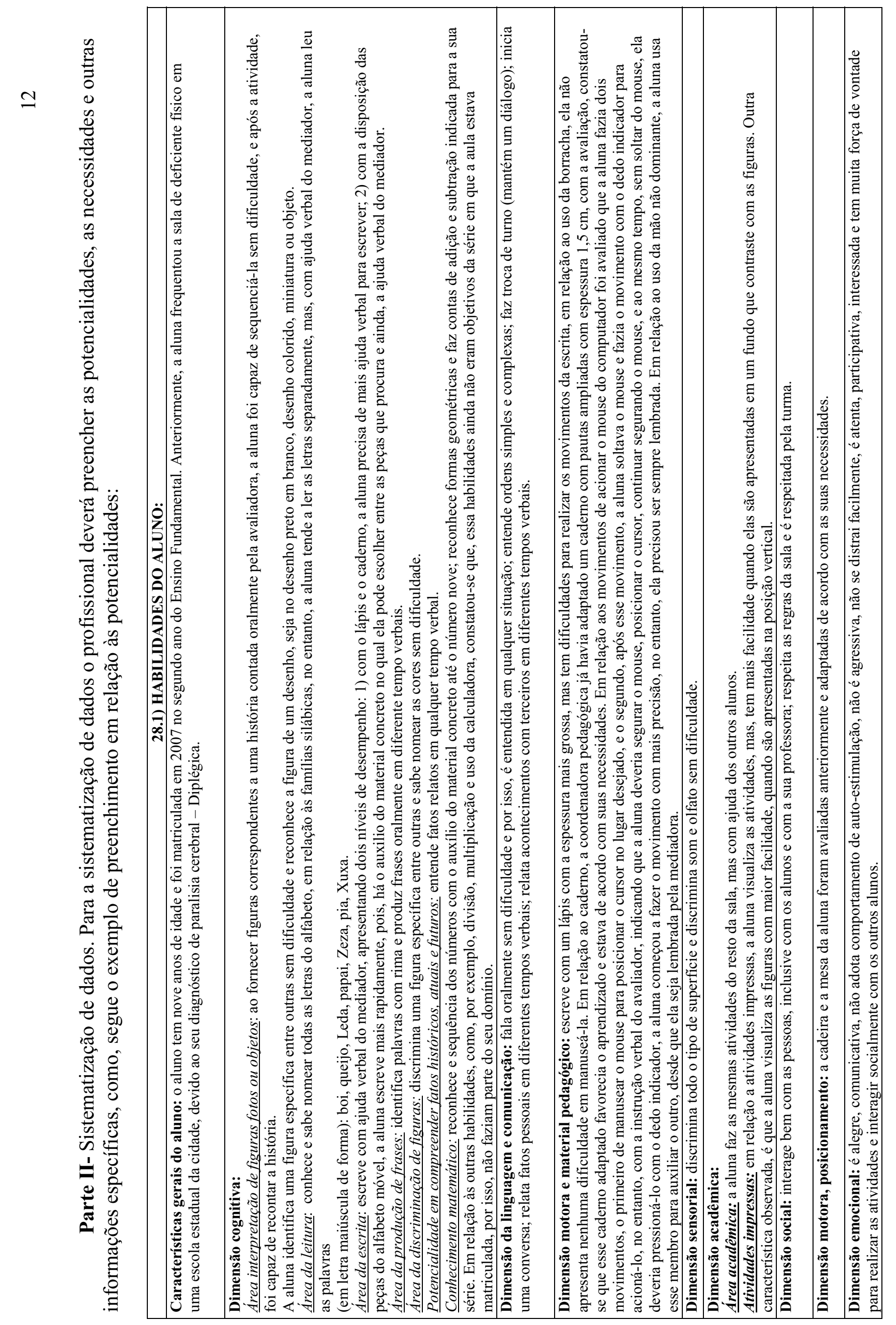




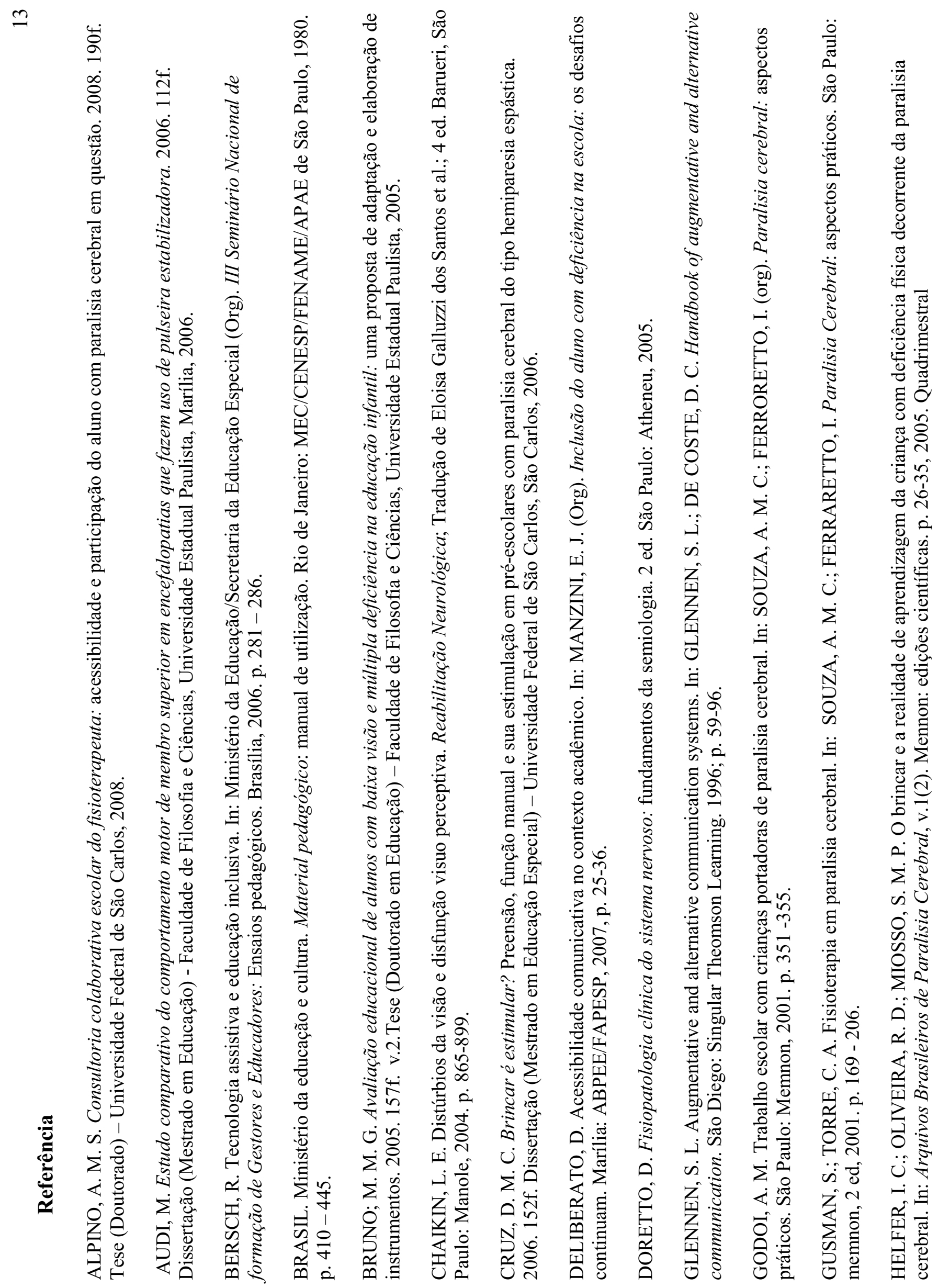


$\pm$

莺

मे

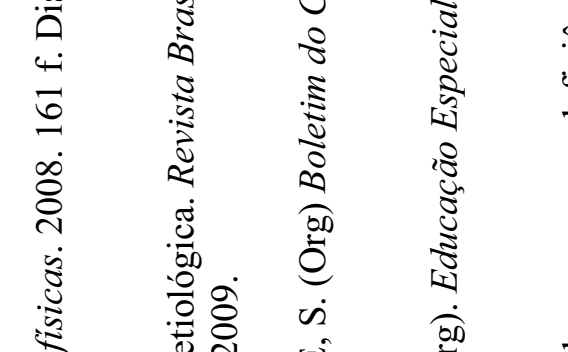

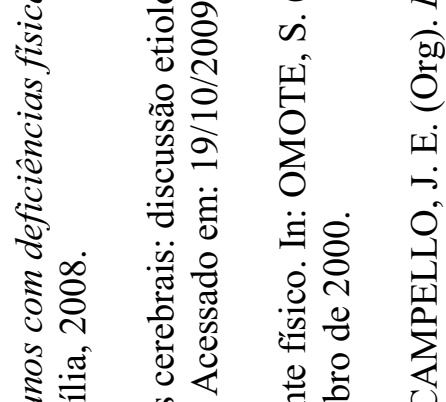

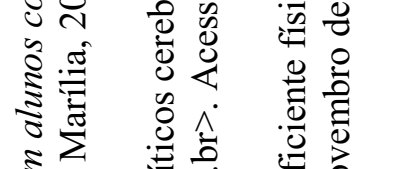

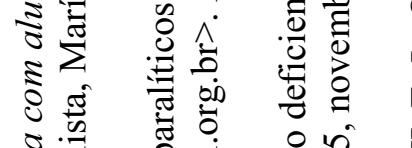

然

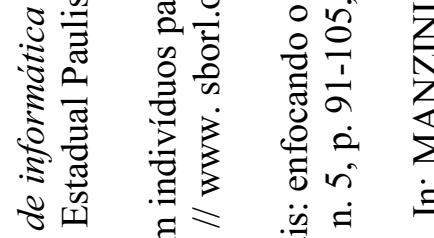

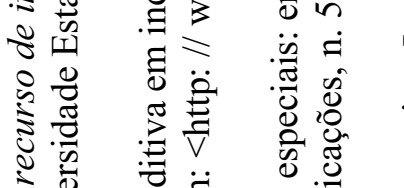

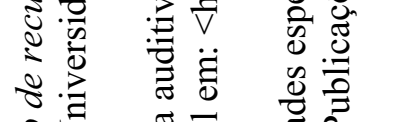

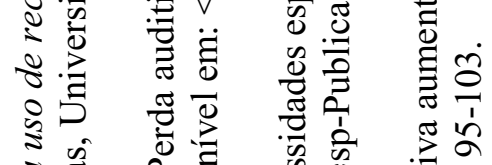

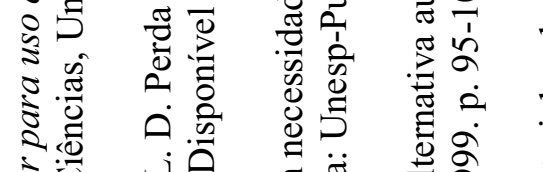

为

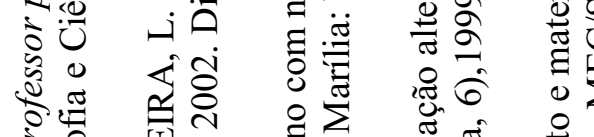

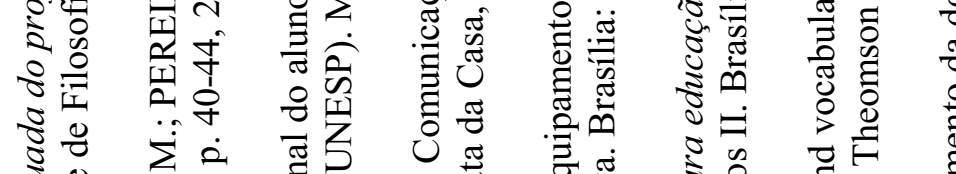

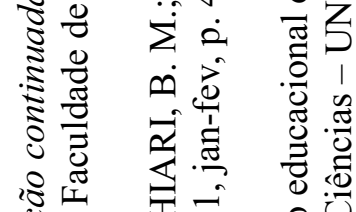

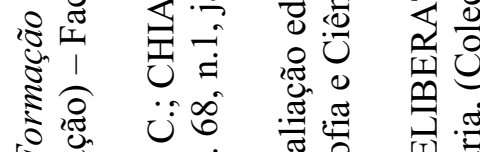

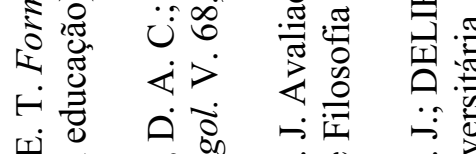

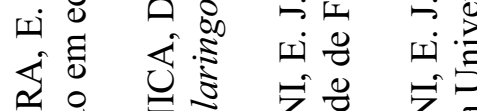

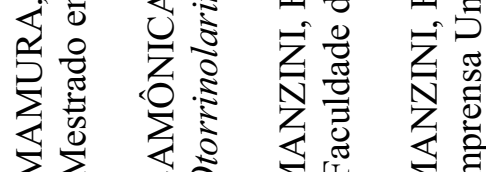

ชิ

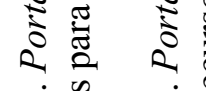

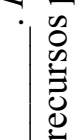

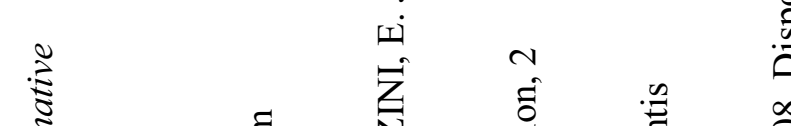

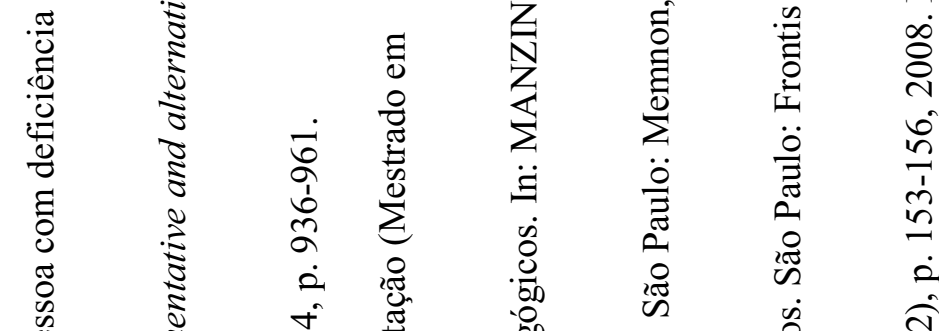

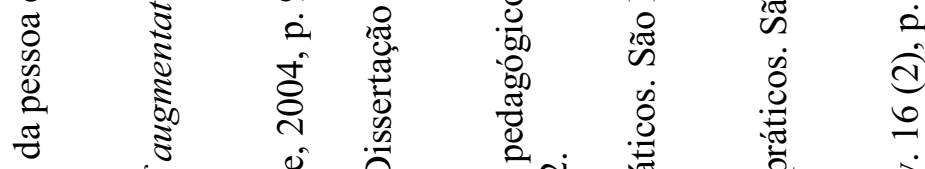

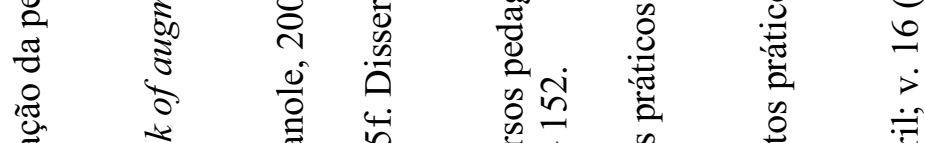

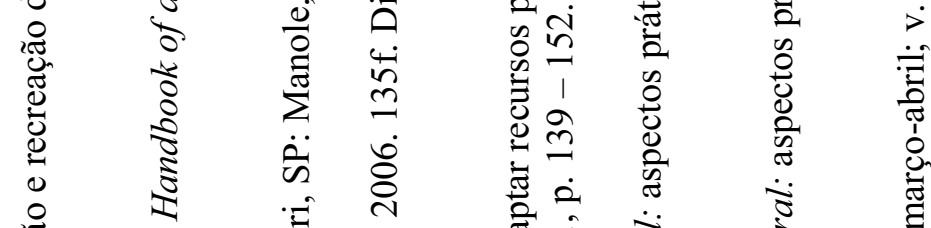

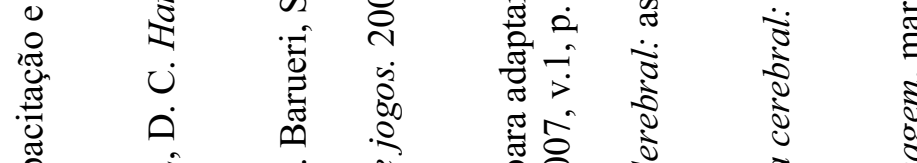

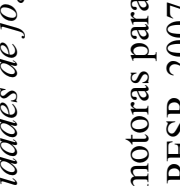

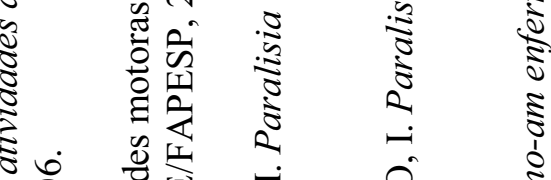

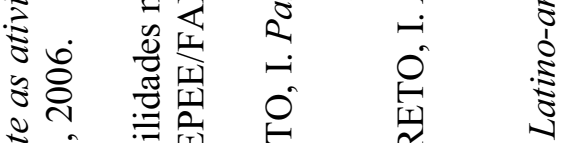

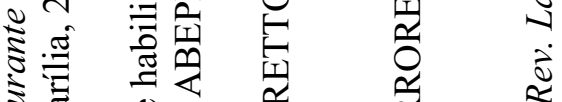

ป

苞

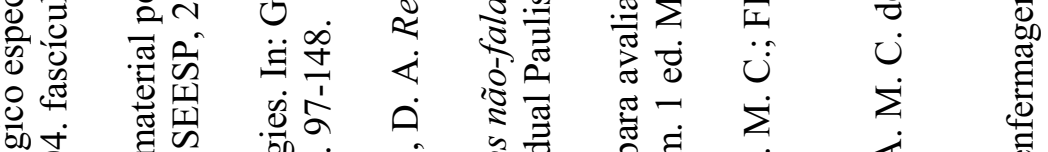

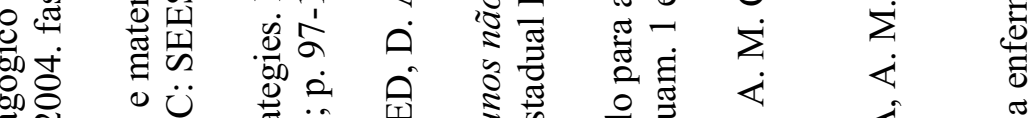

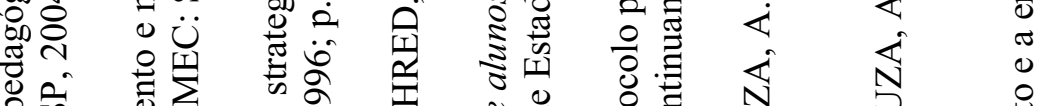

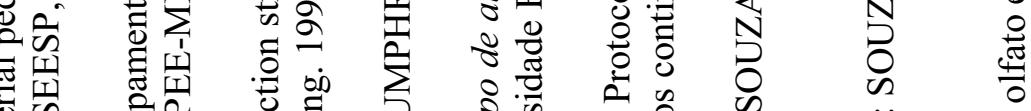

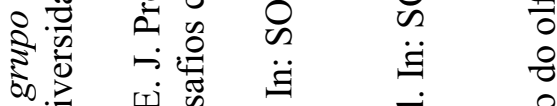

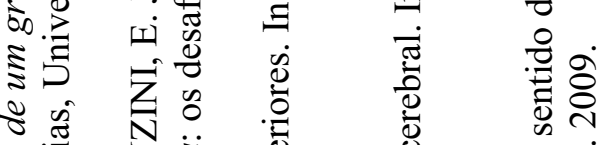

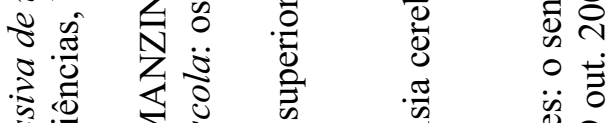

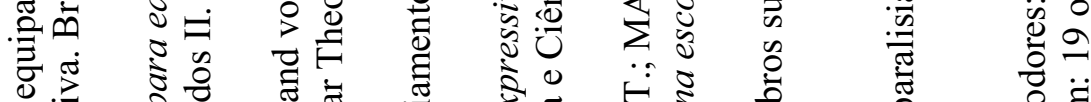

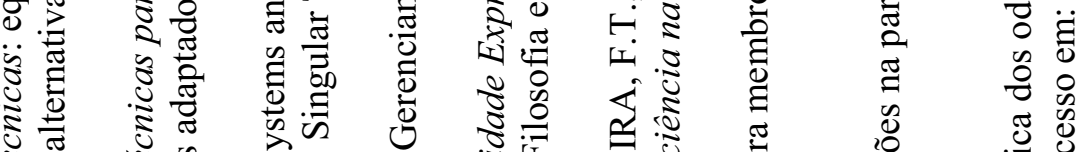

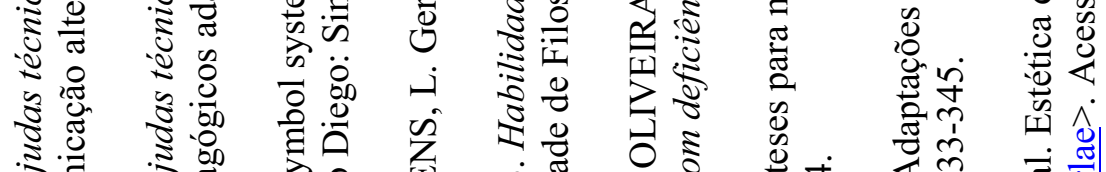

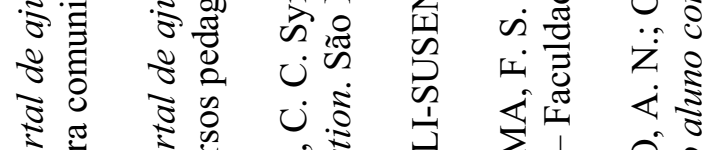

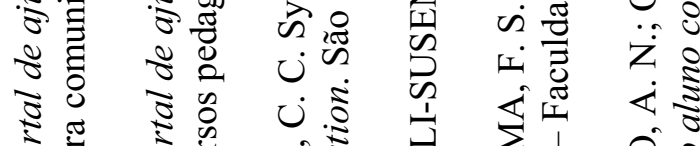

通

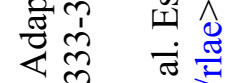

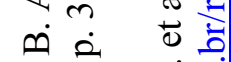

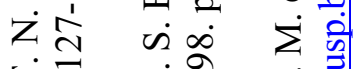

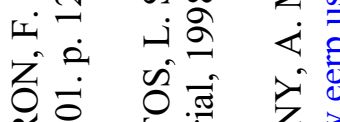

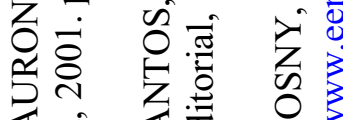


APÊNDICE B- PROTOCOLO PARA PRESCRIÇÃO OU ADAPTAÇÃO DE RECURSOS PEDAGÓGICOS PARA ALUNOS COM PARALISIA CEREBRAL 


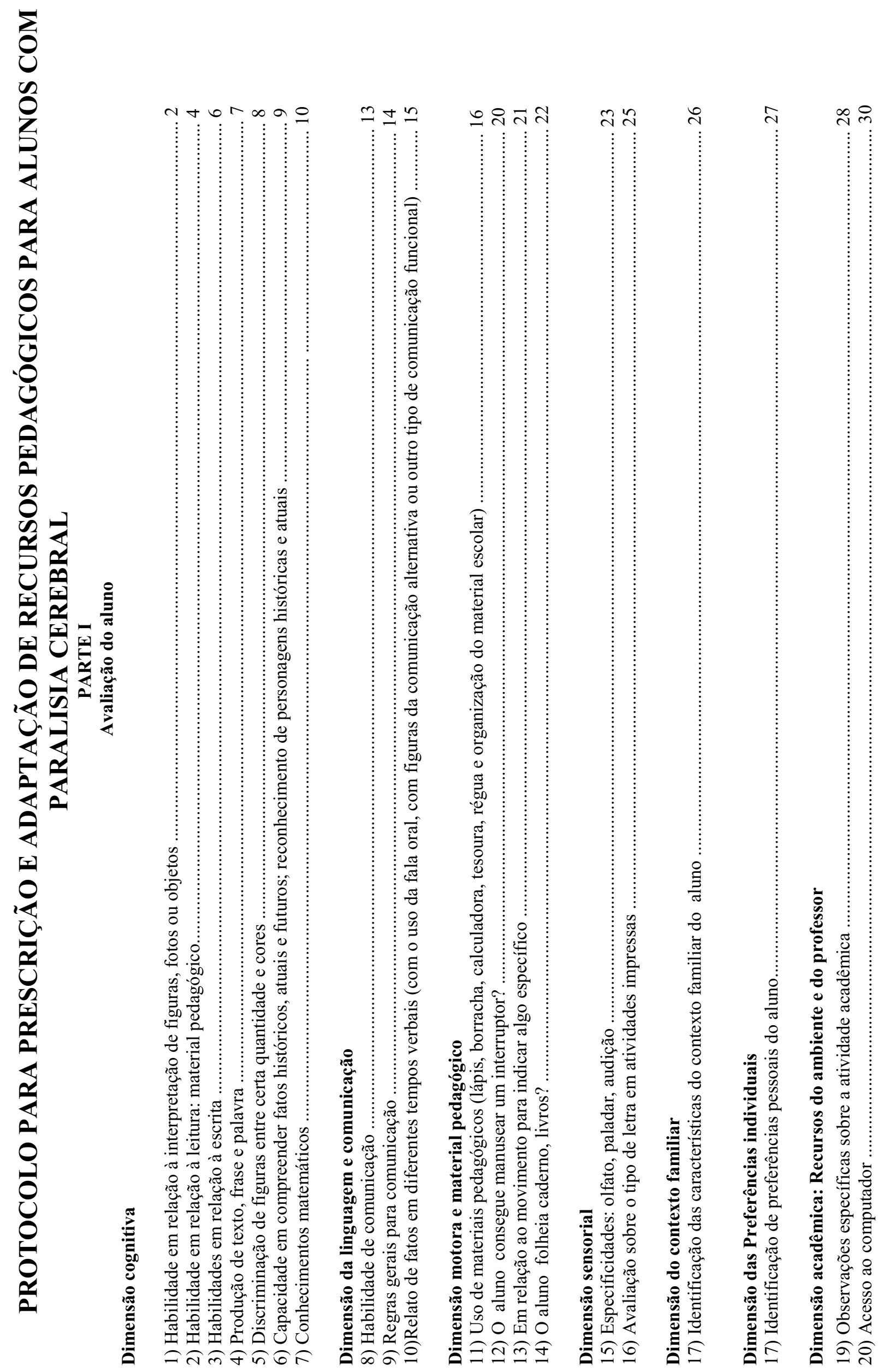




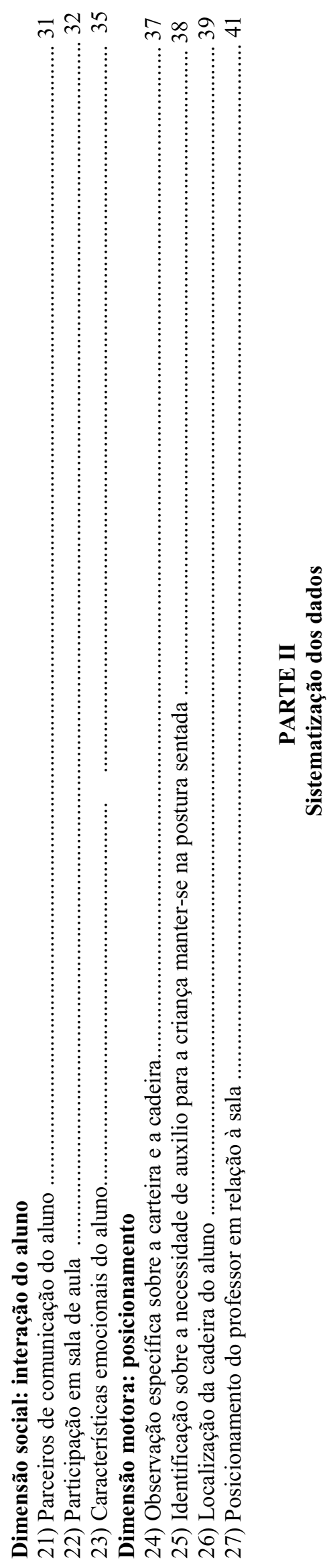

丹学专骂

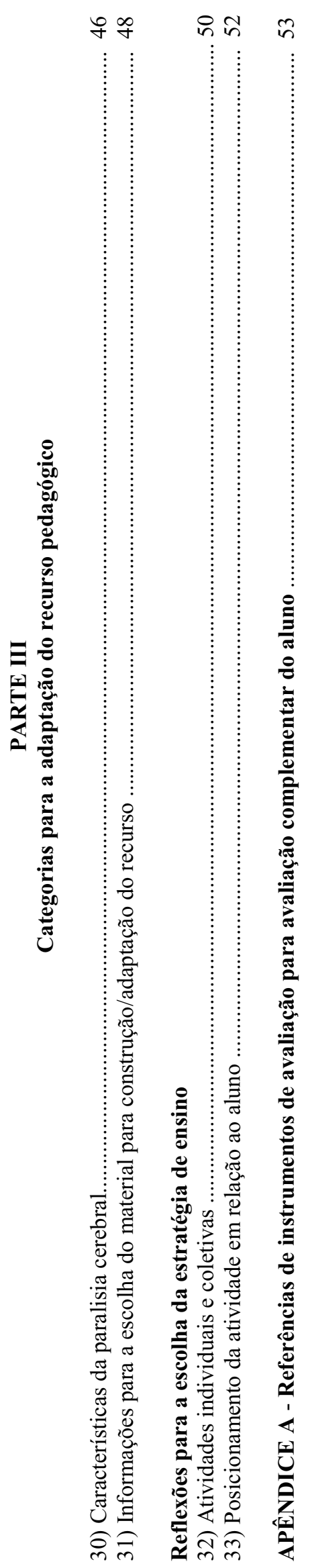




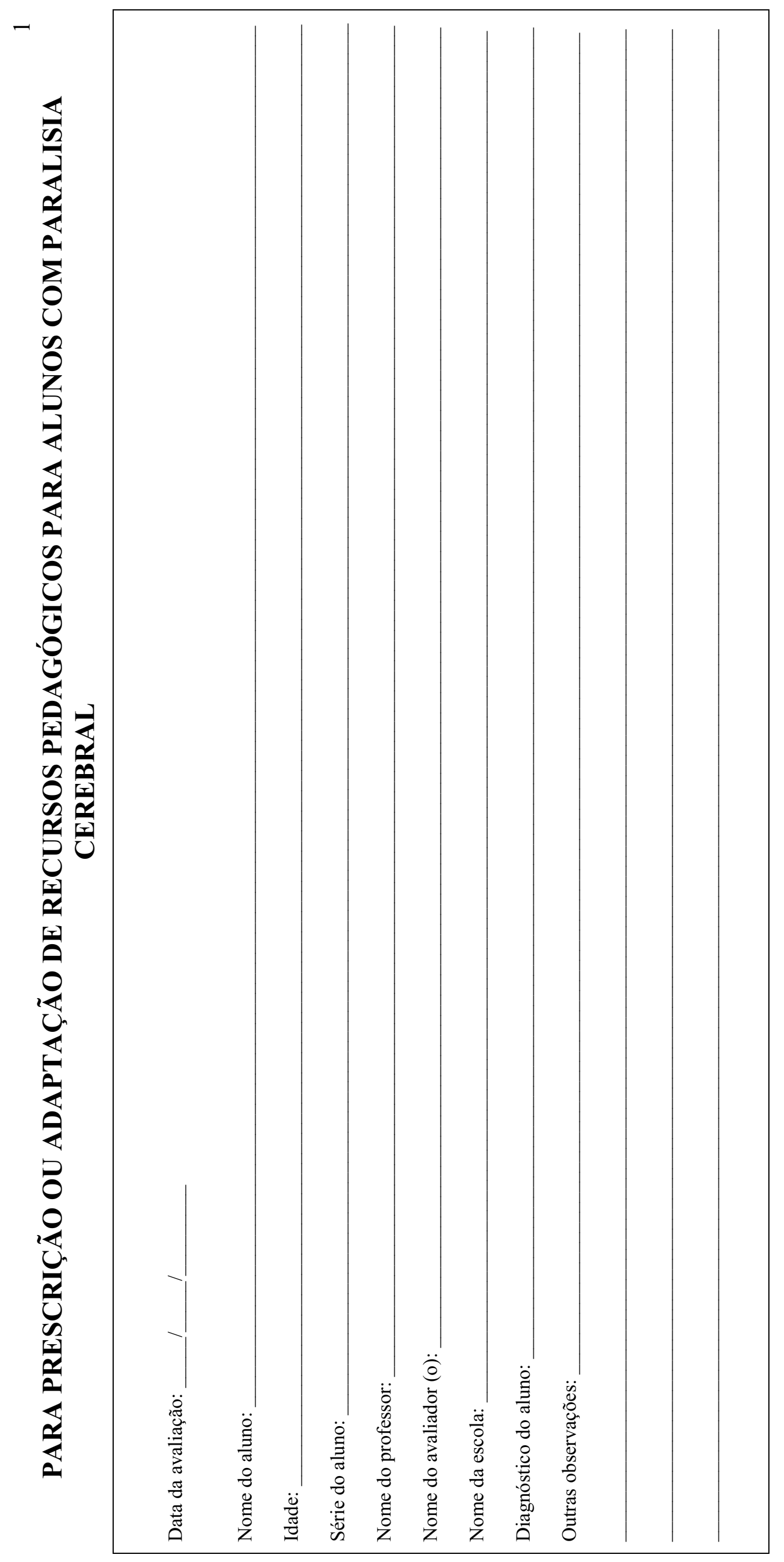

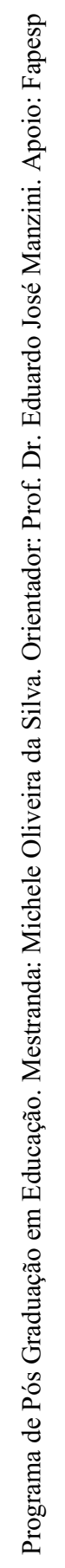




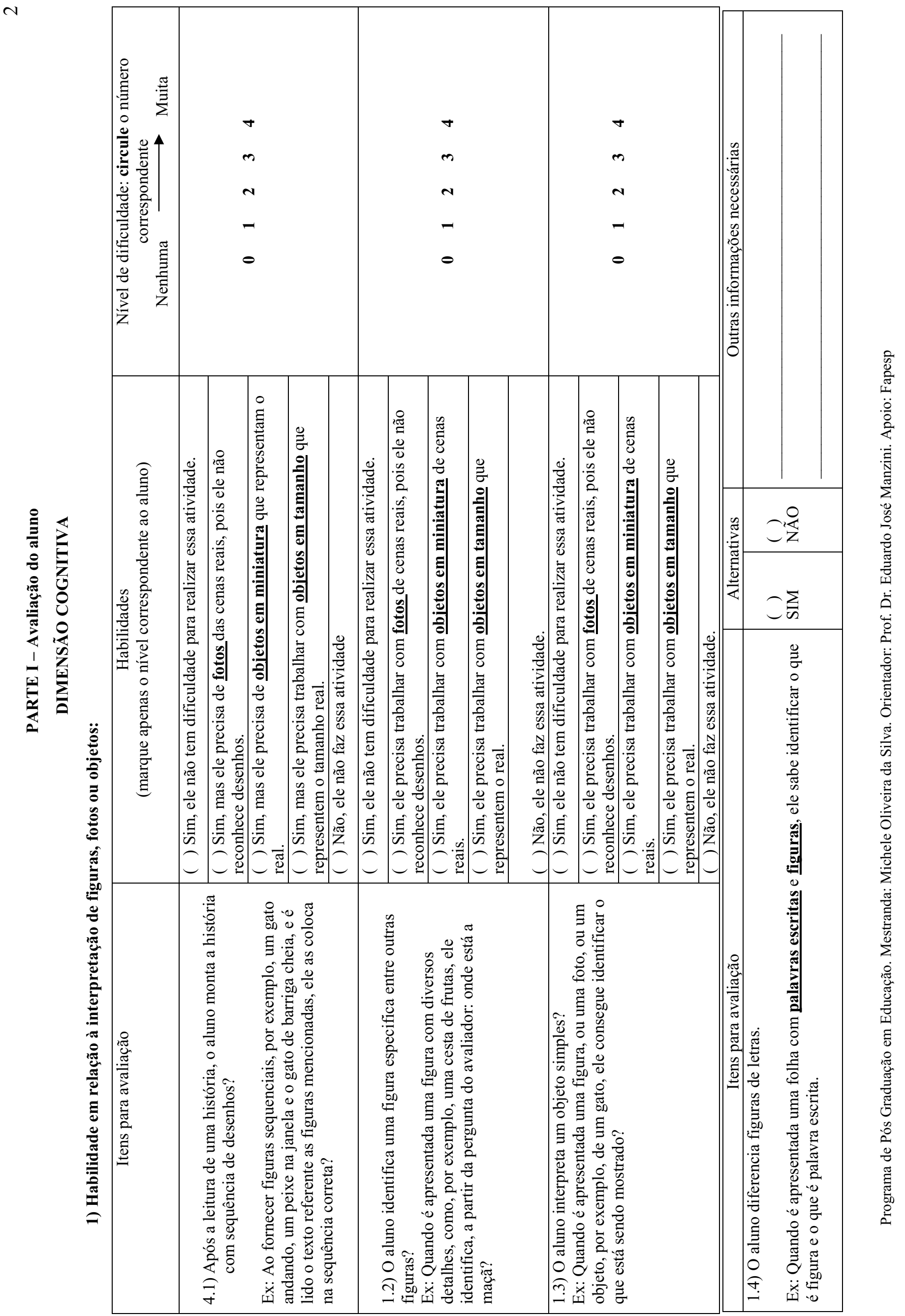



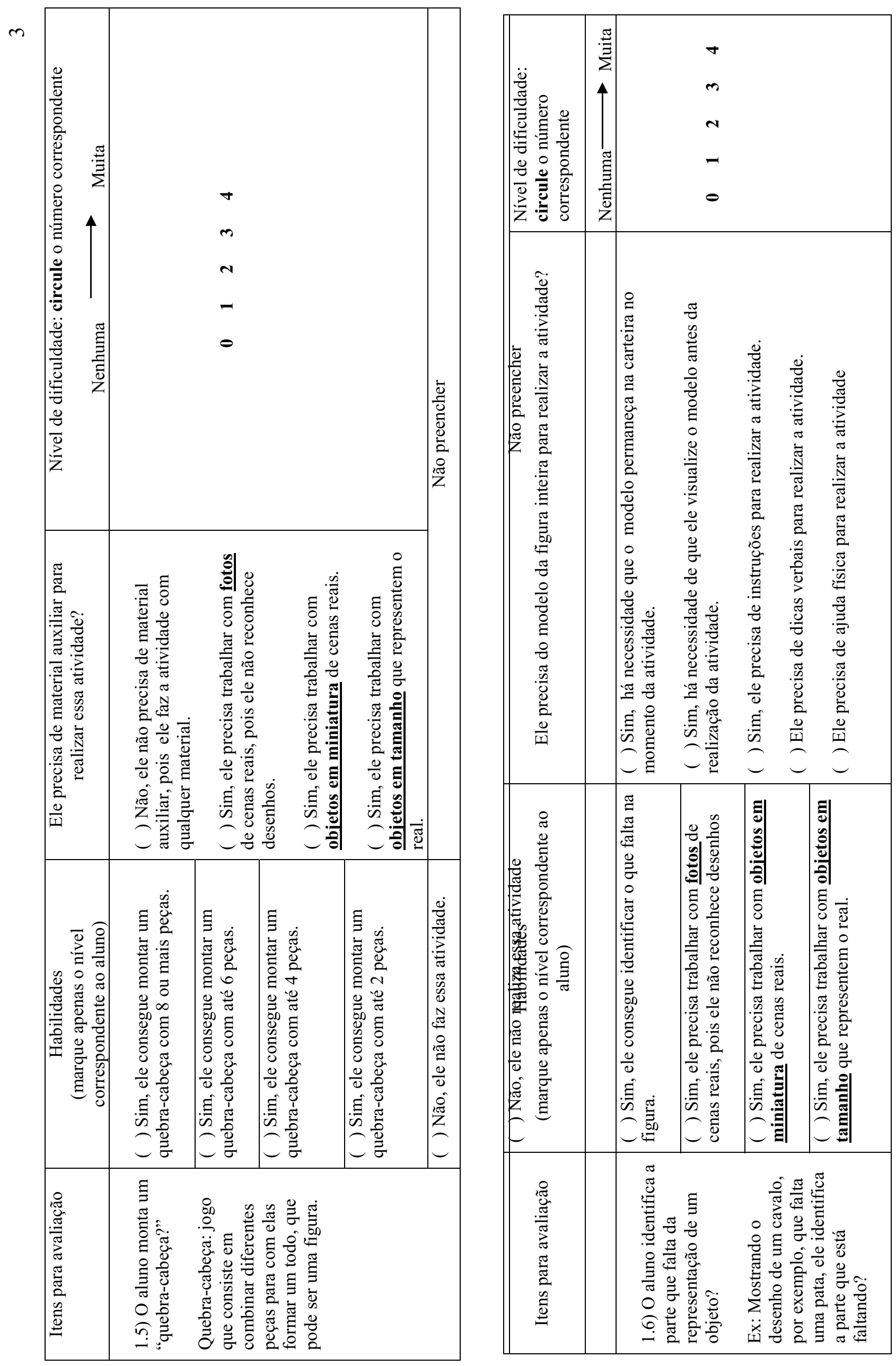

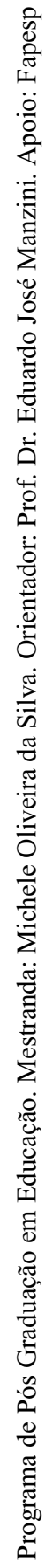




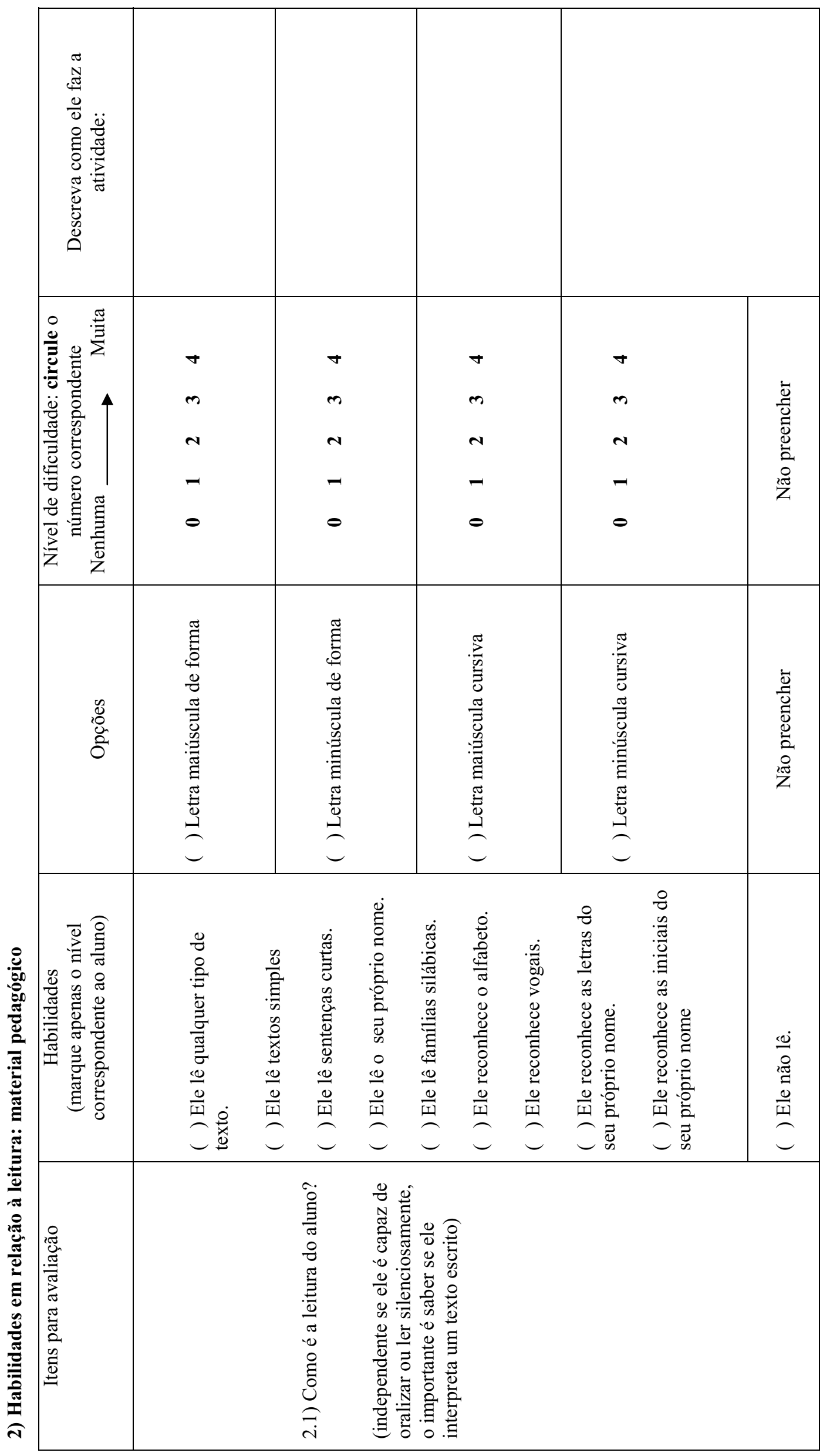




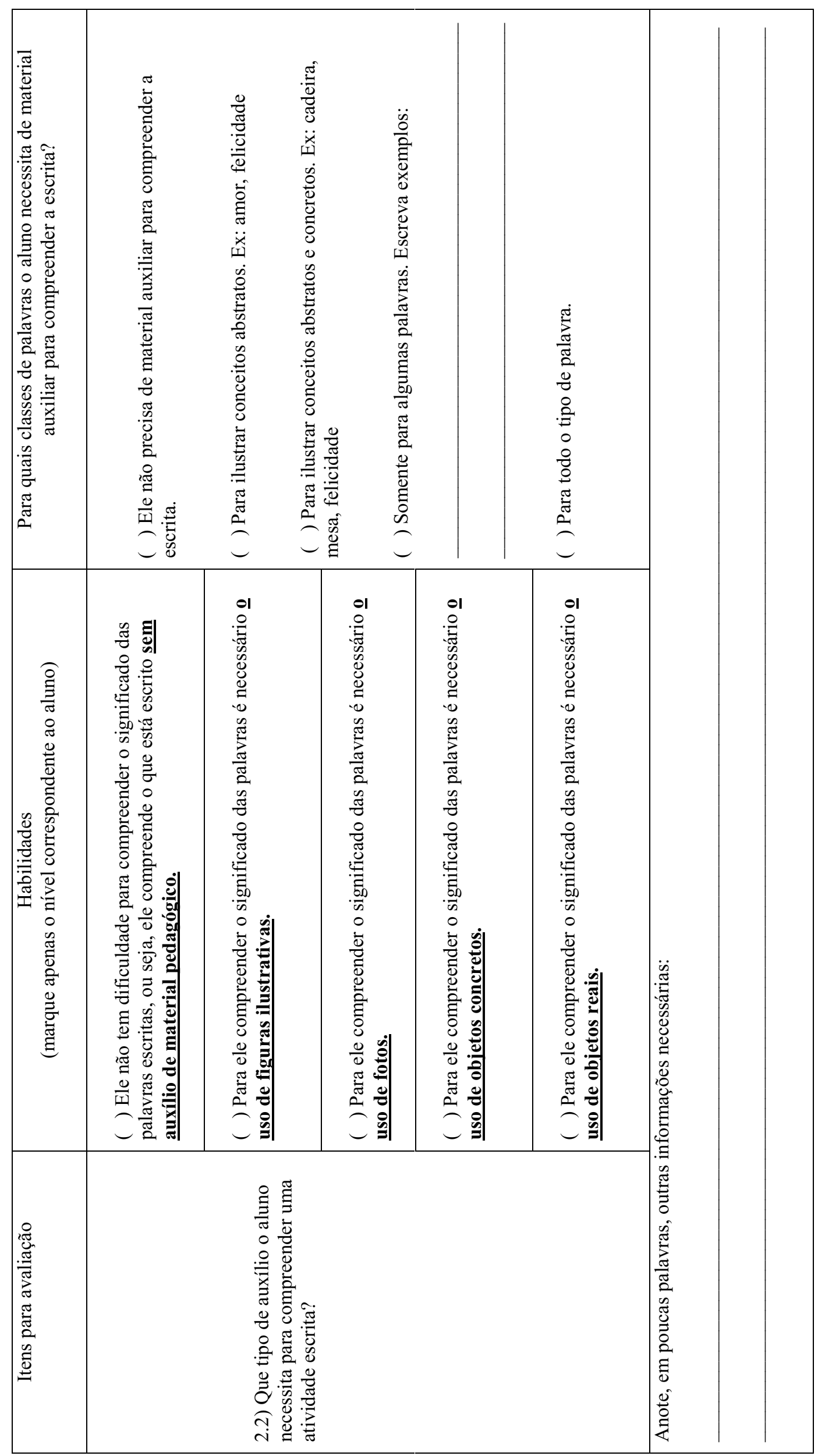

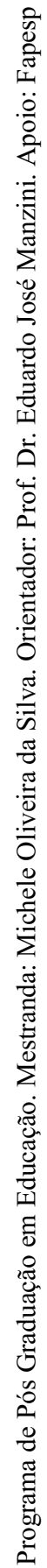




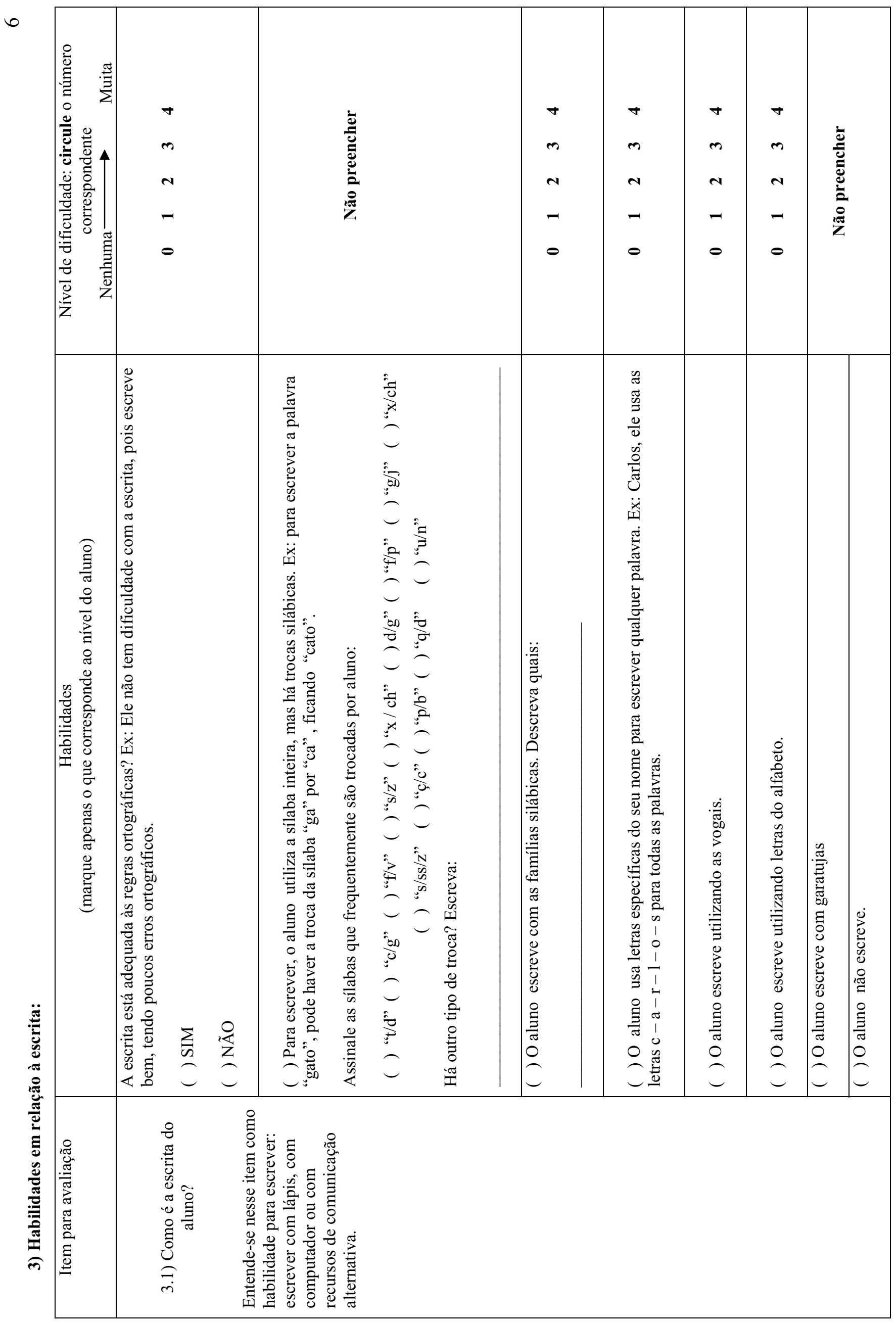




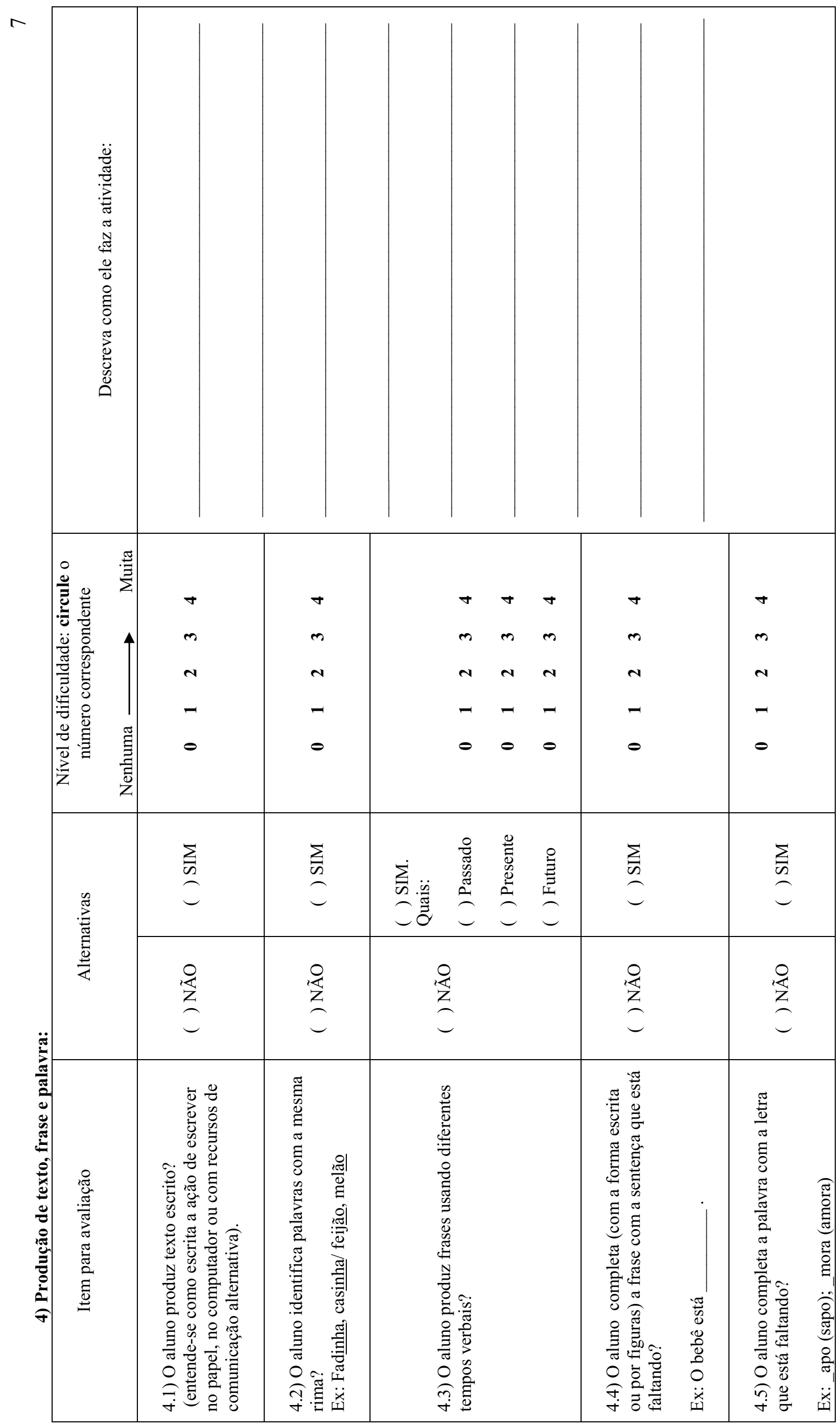

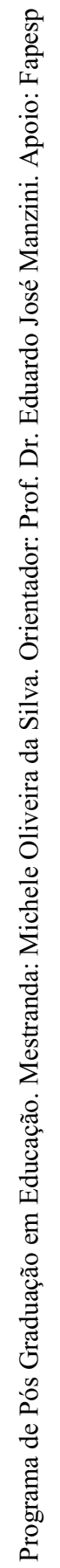




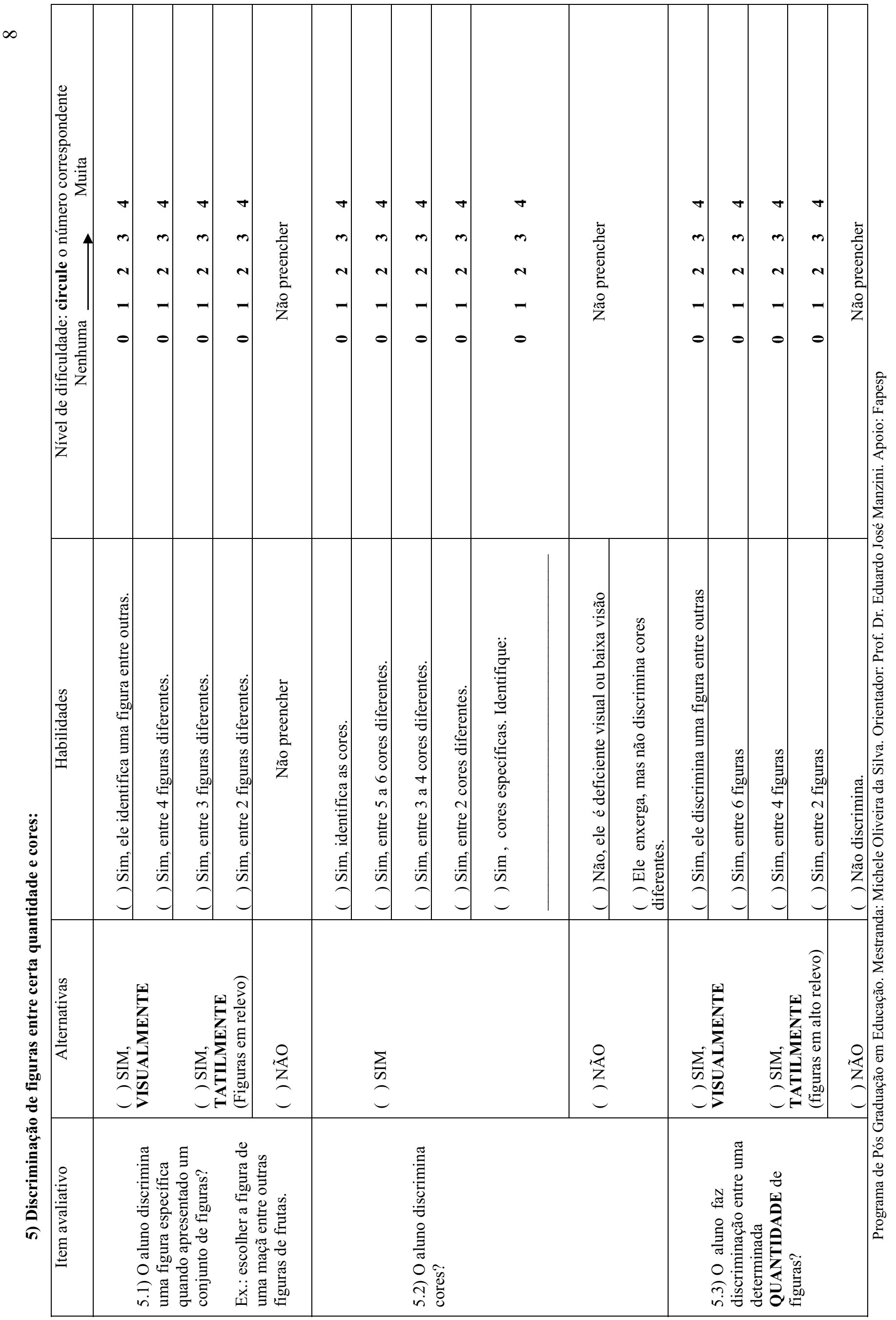




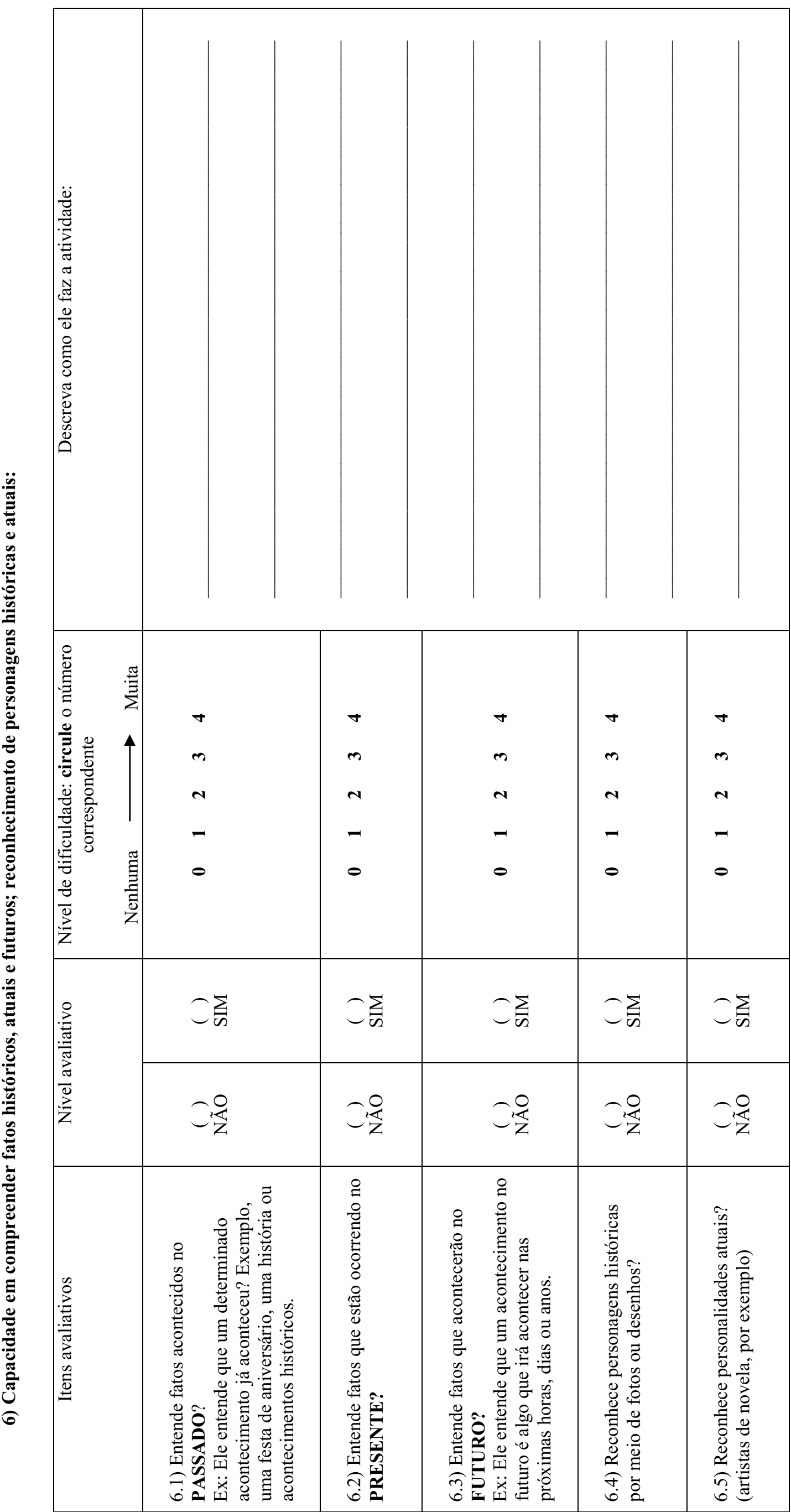




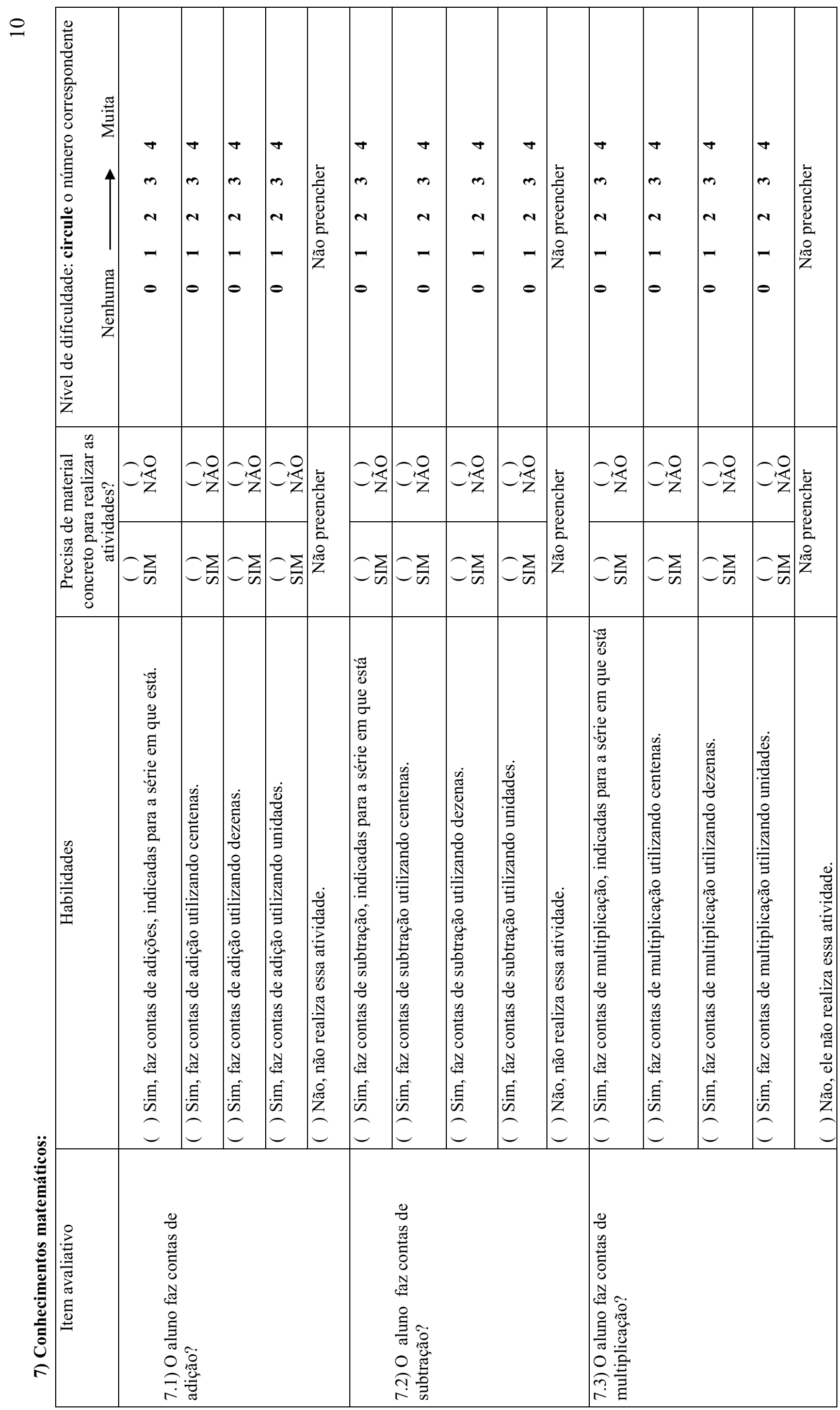

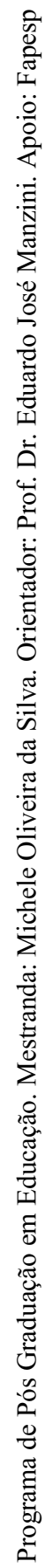




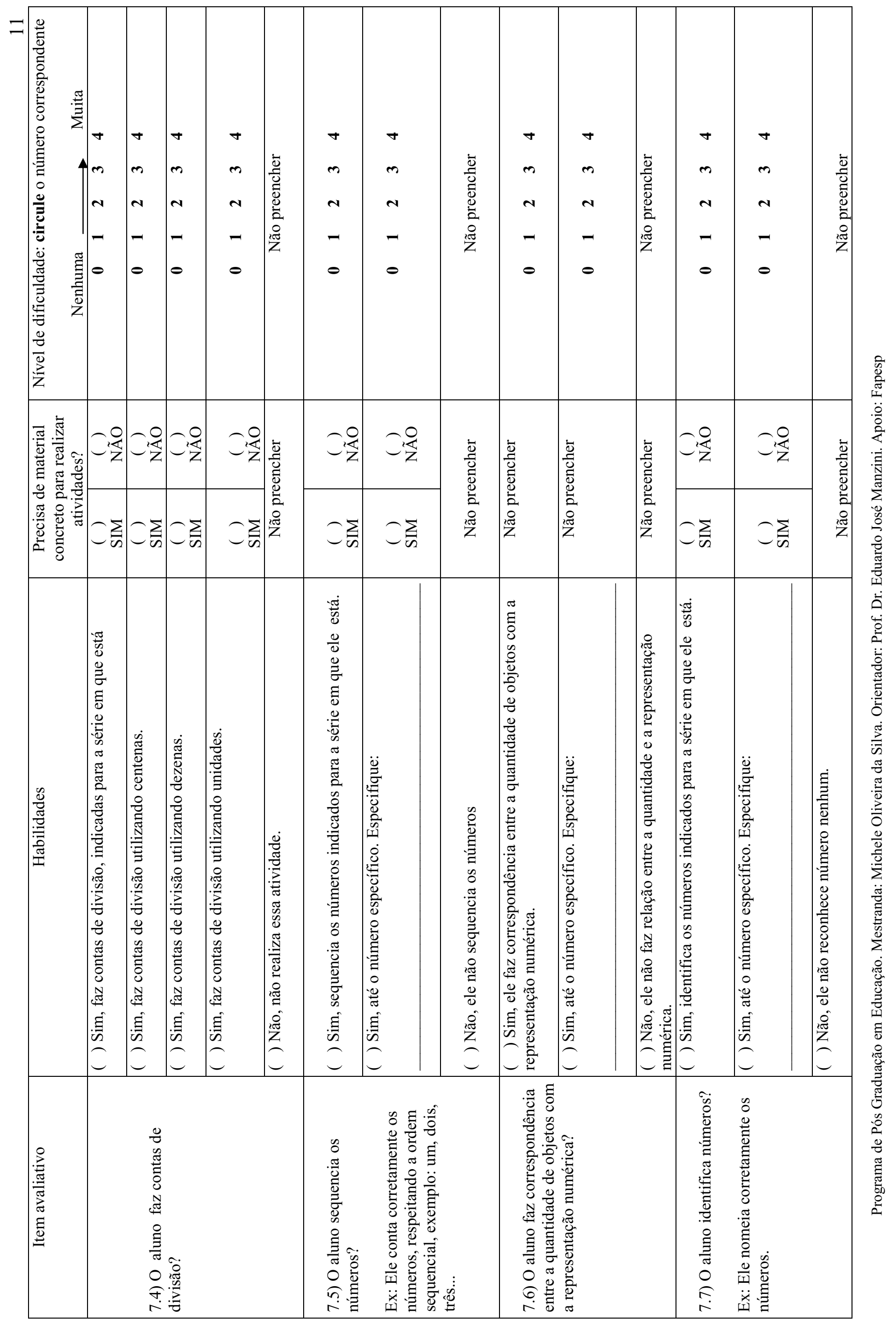




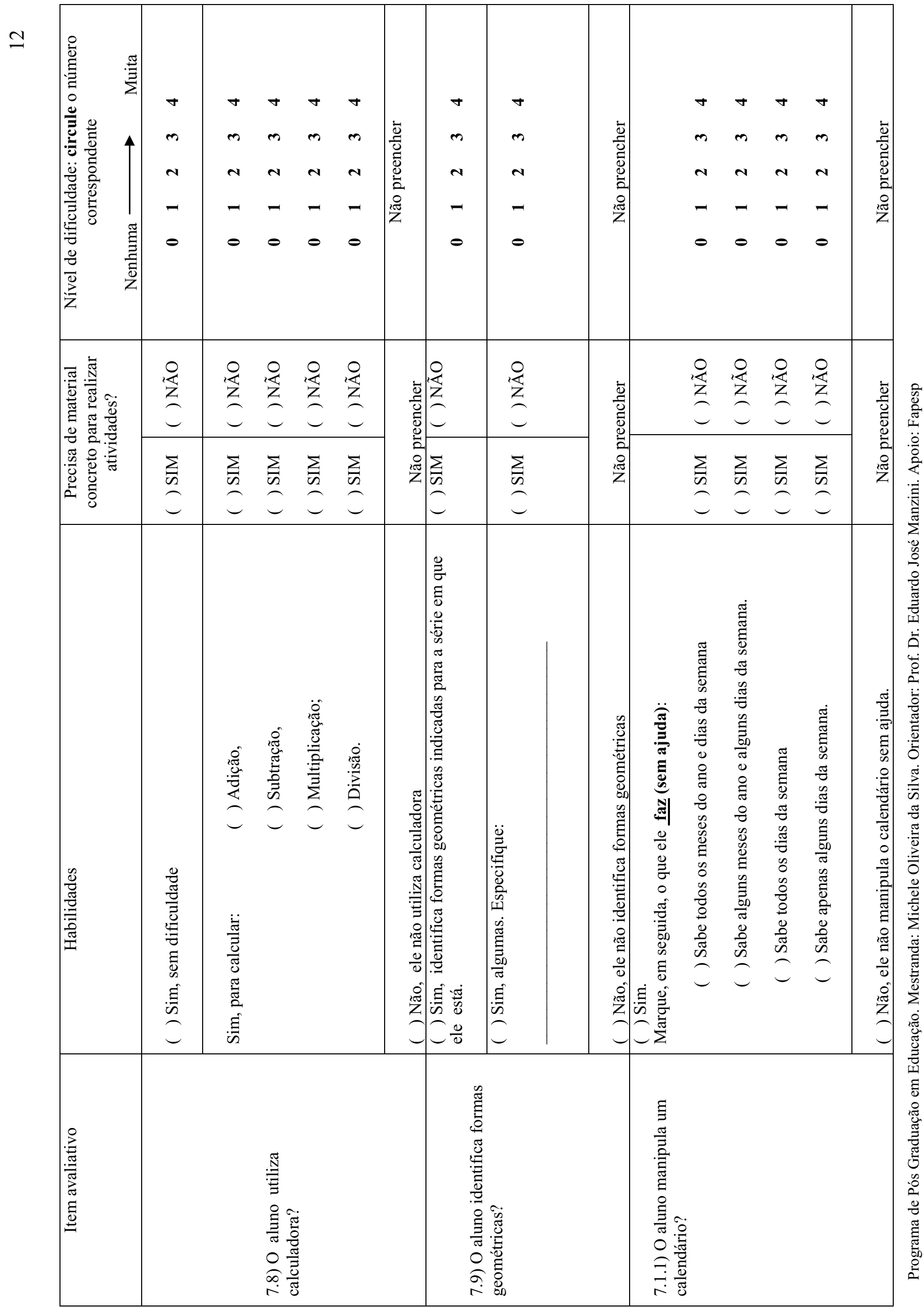


9

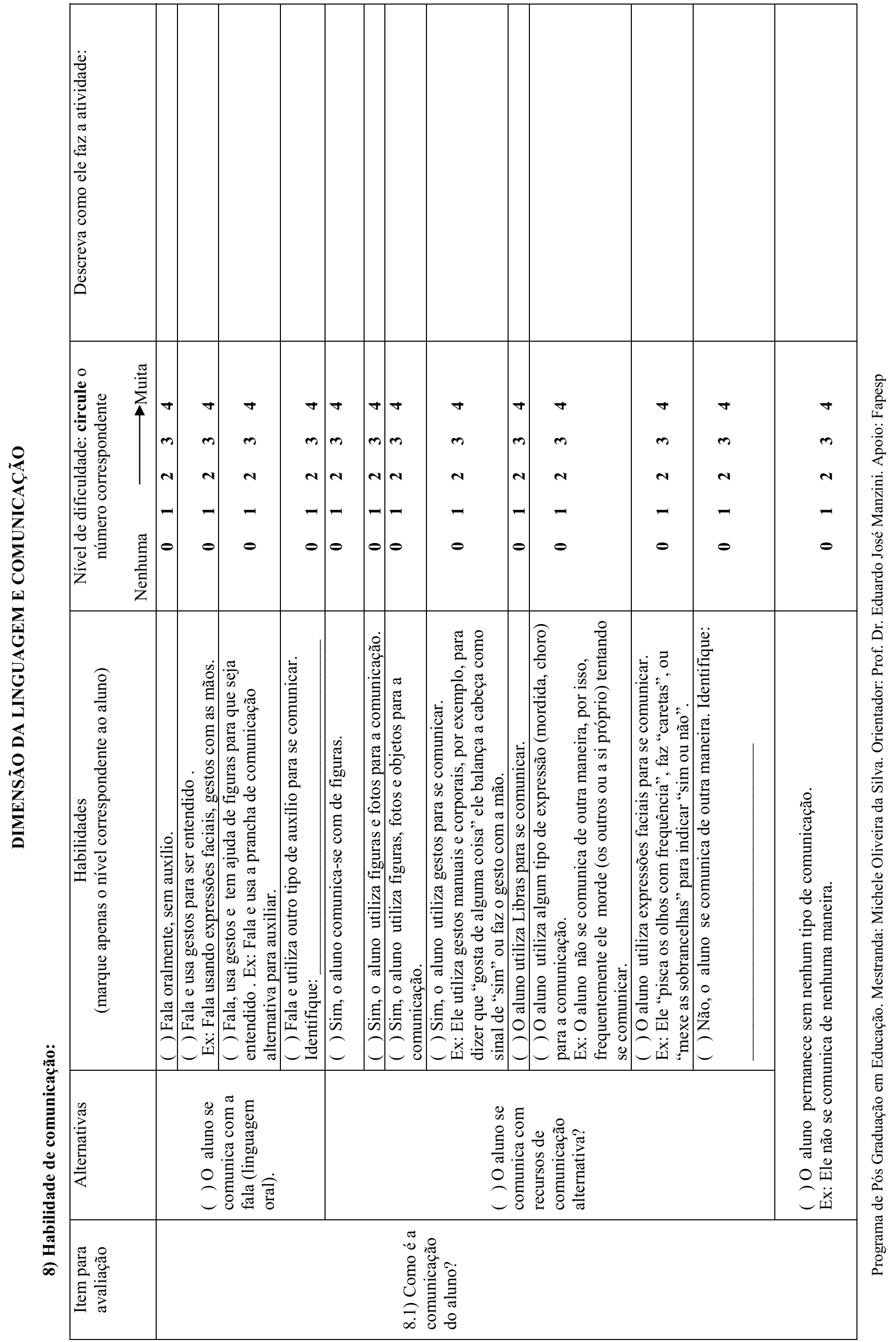


$\pm$

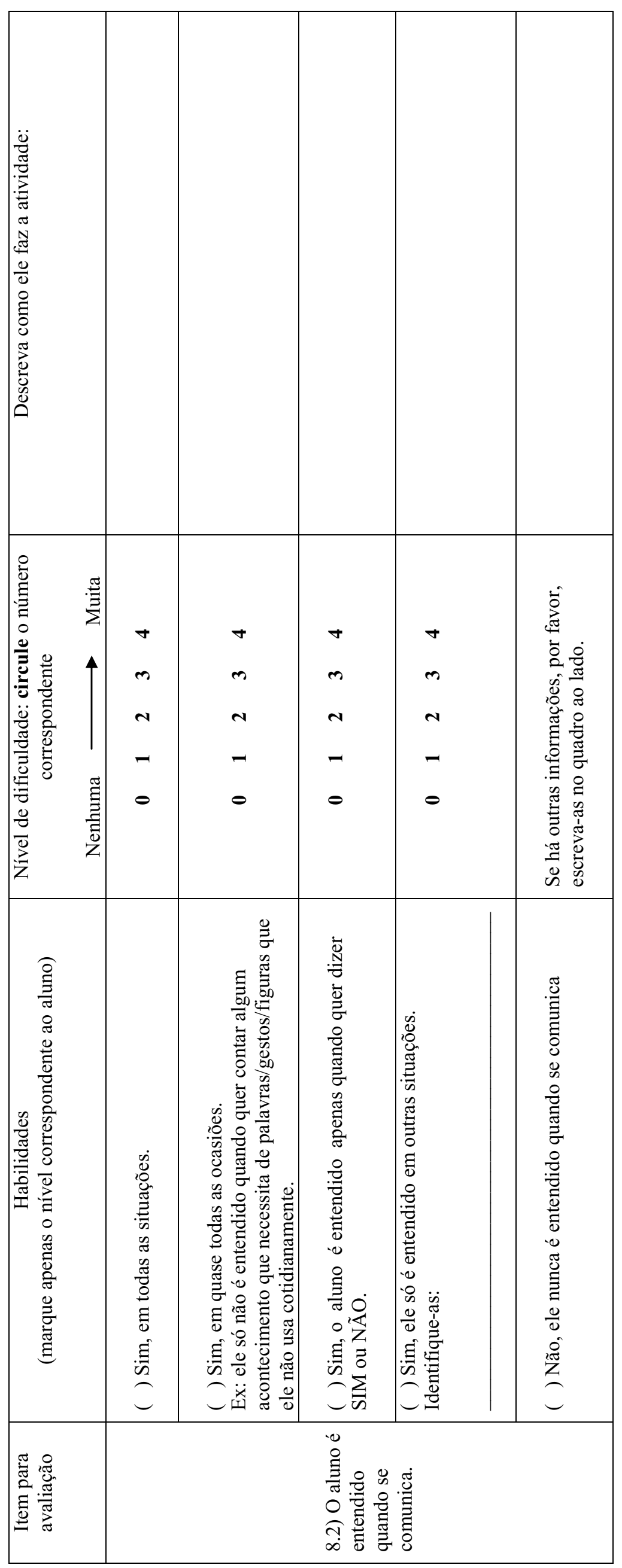

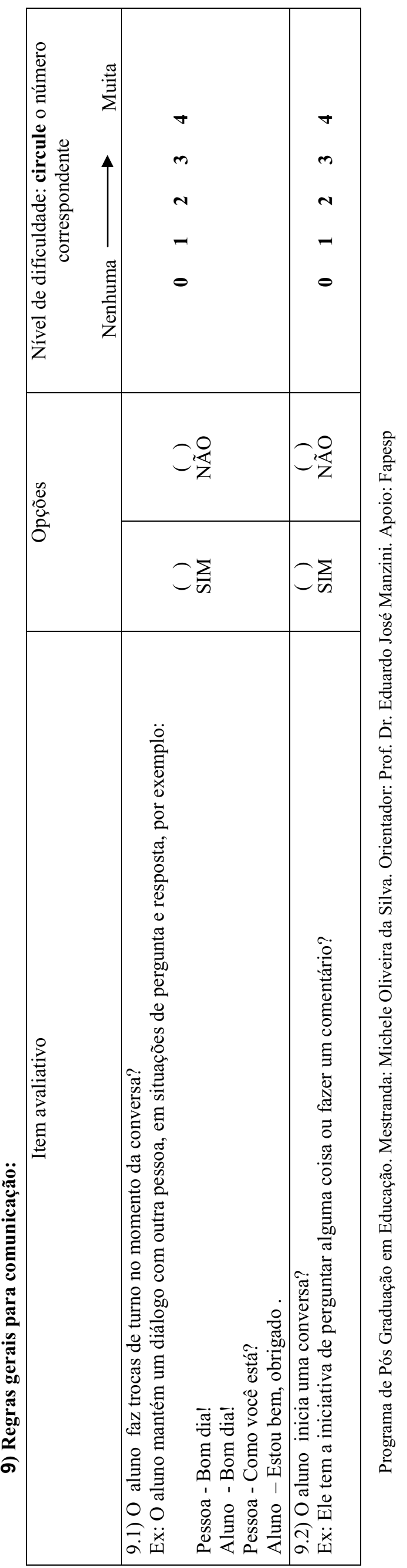




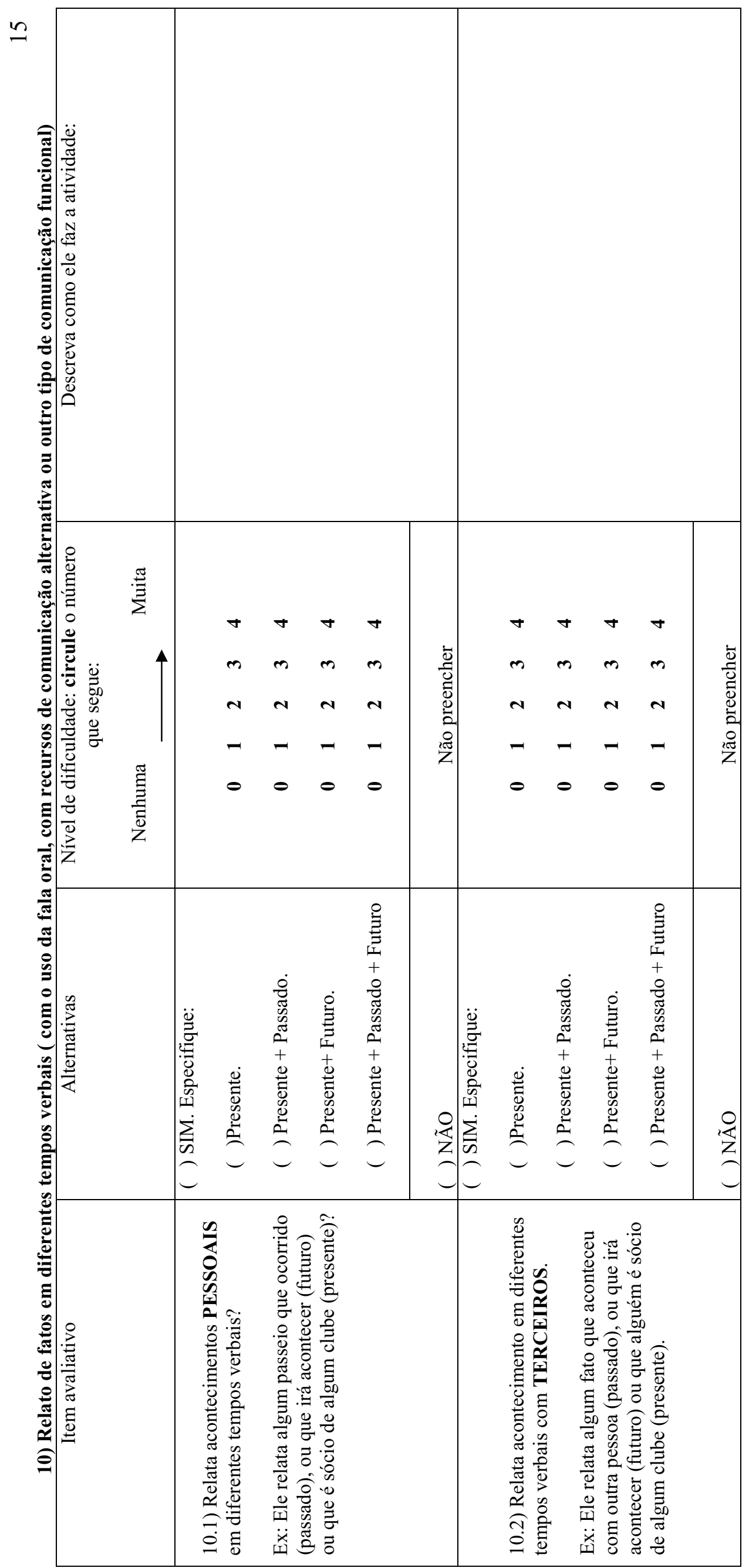




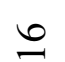

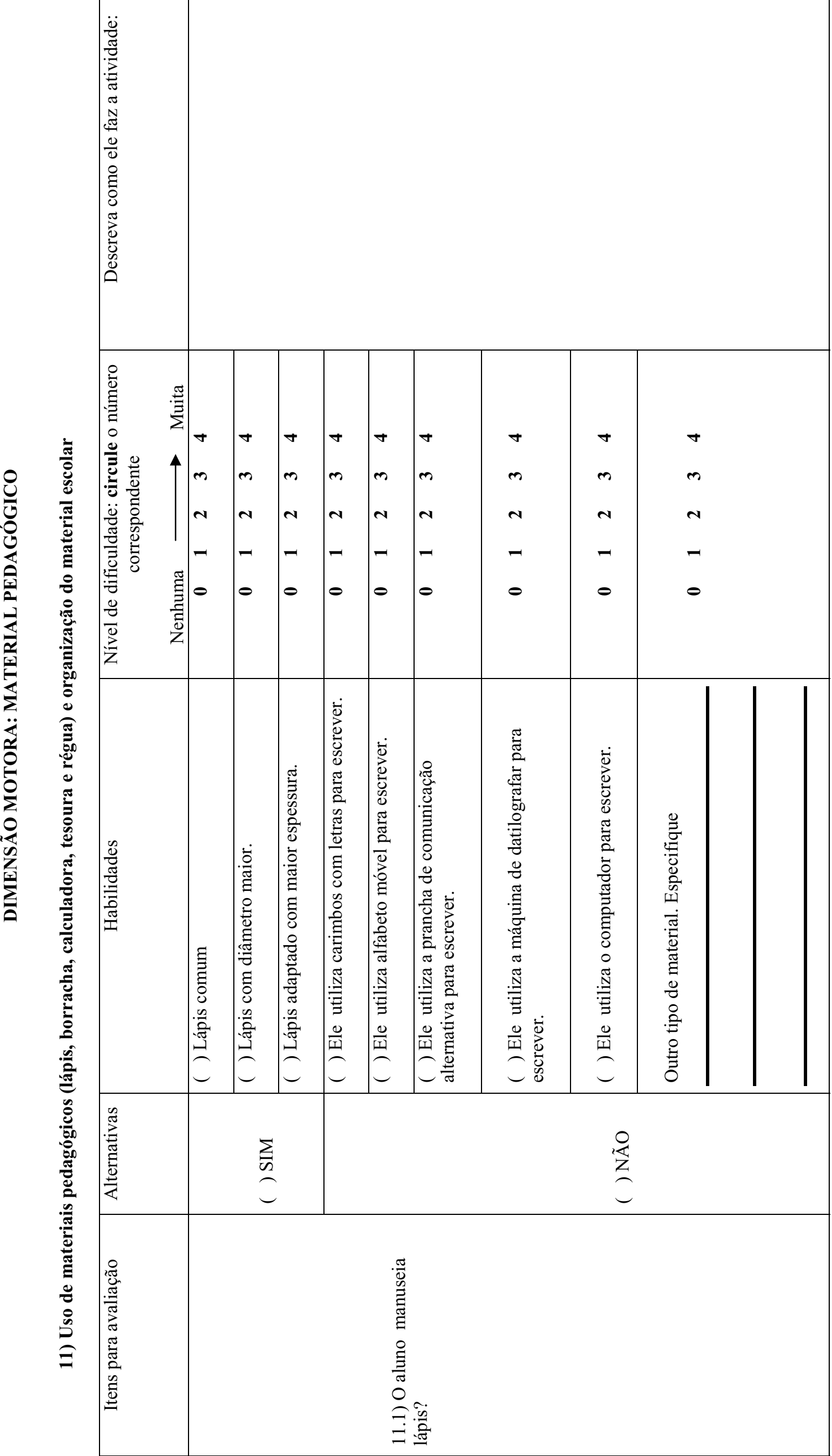




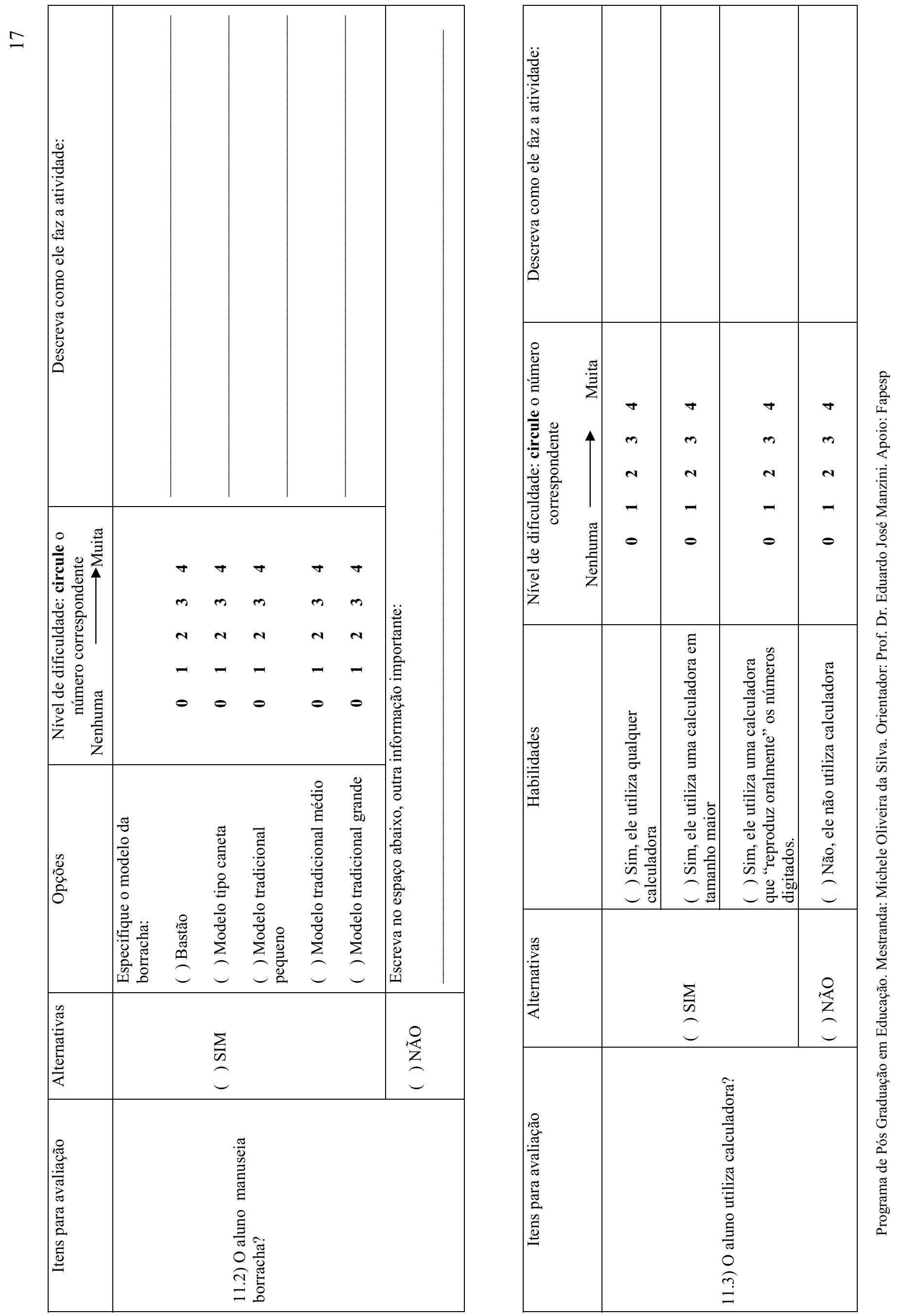




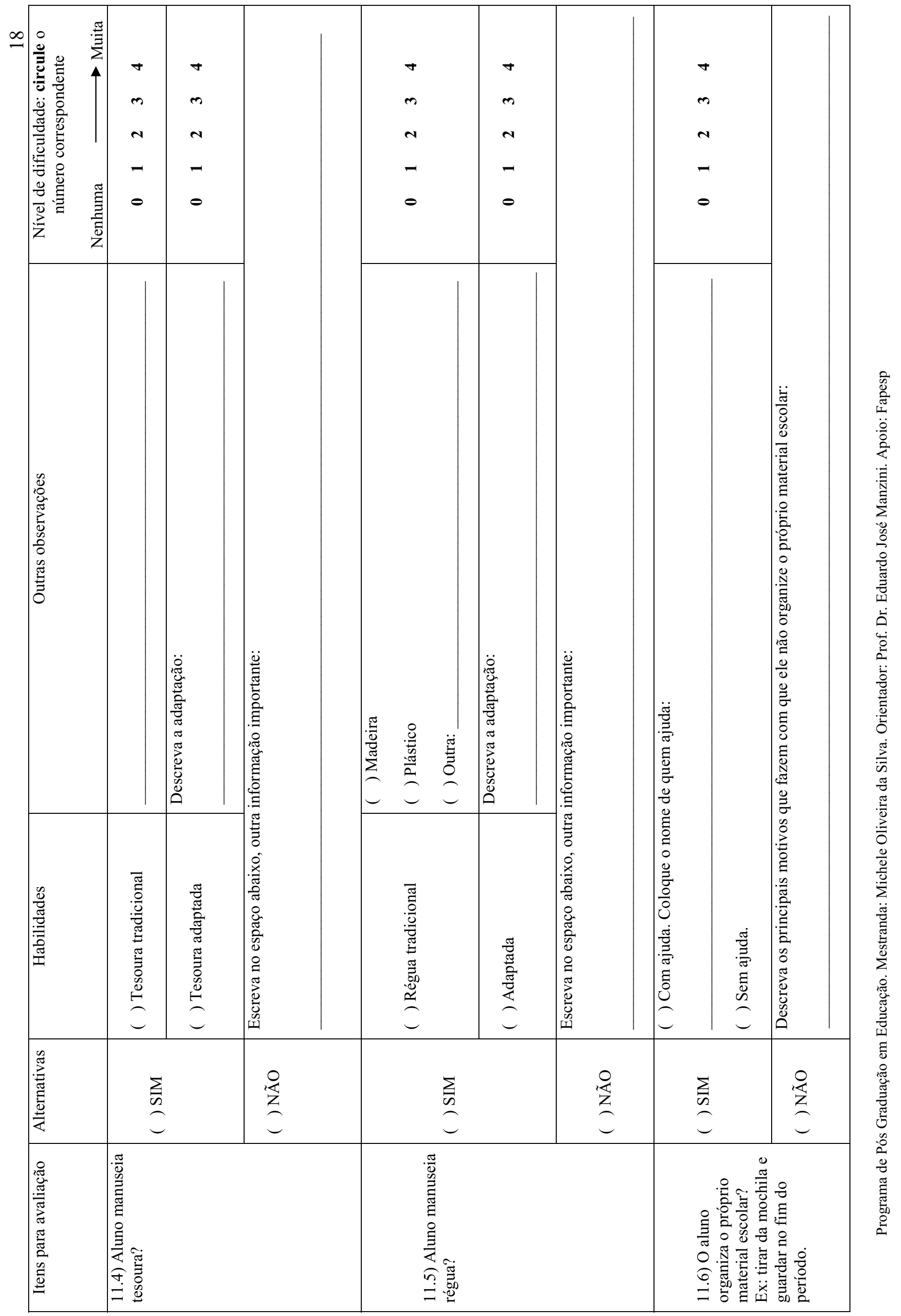




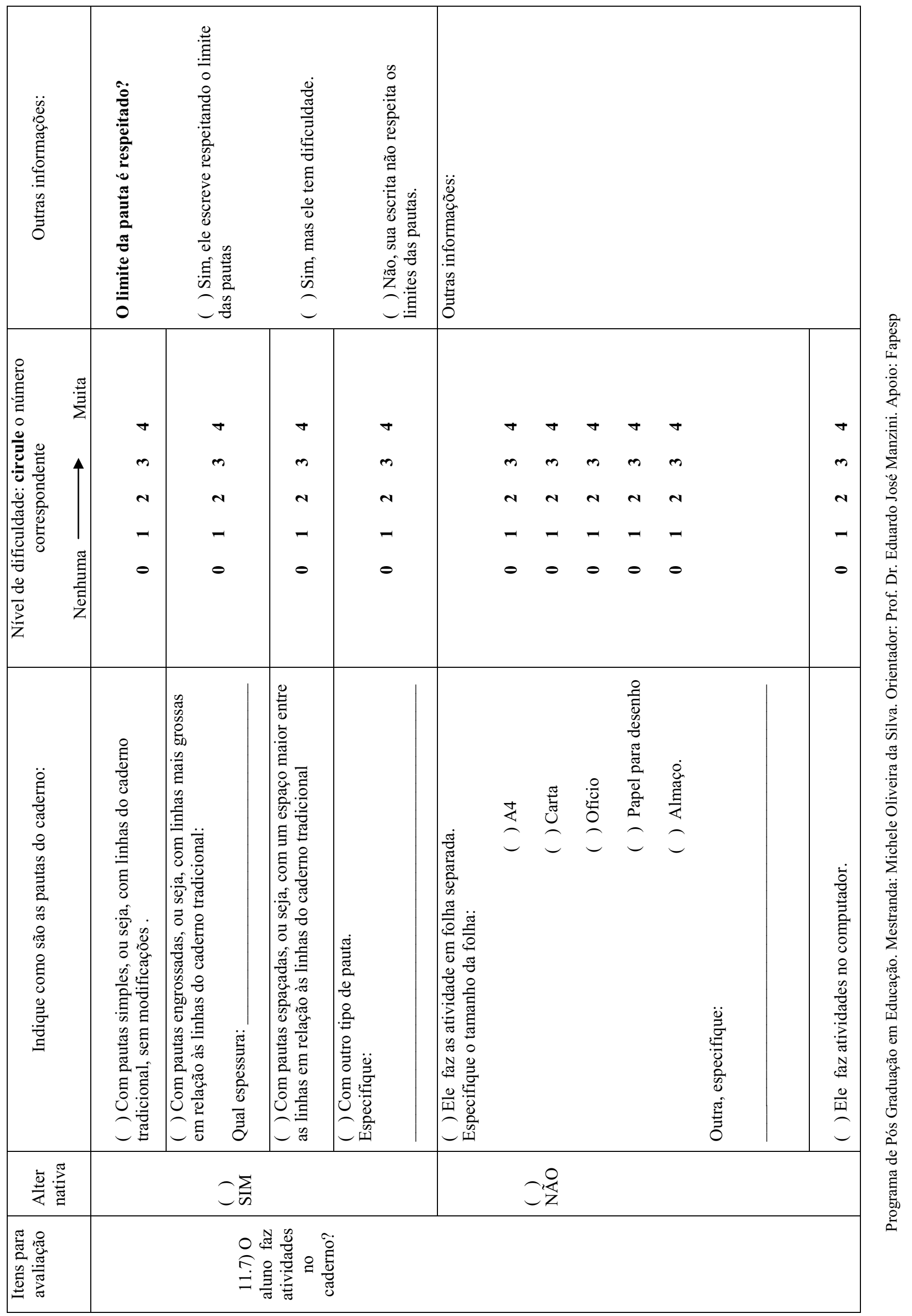


오

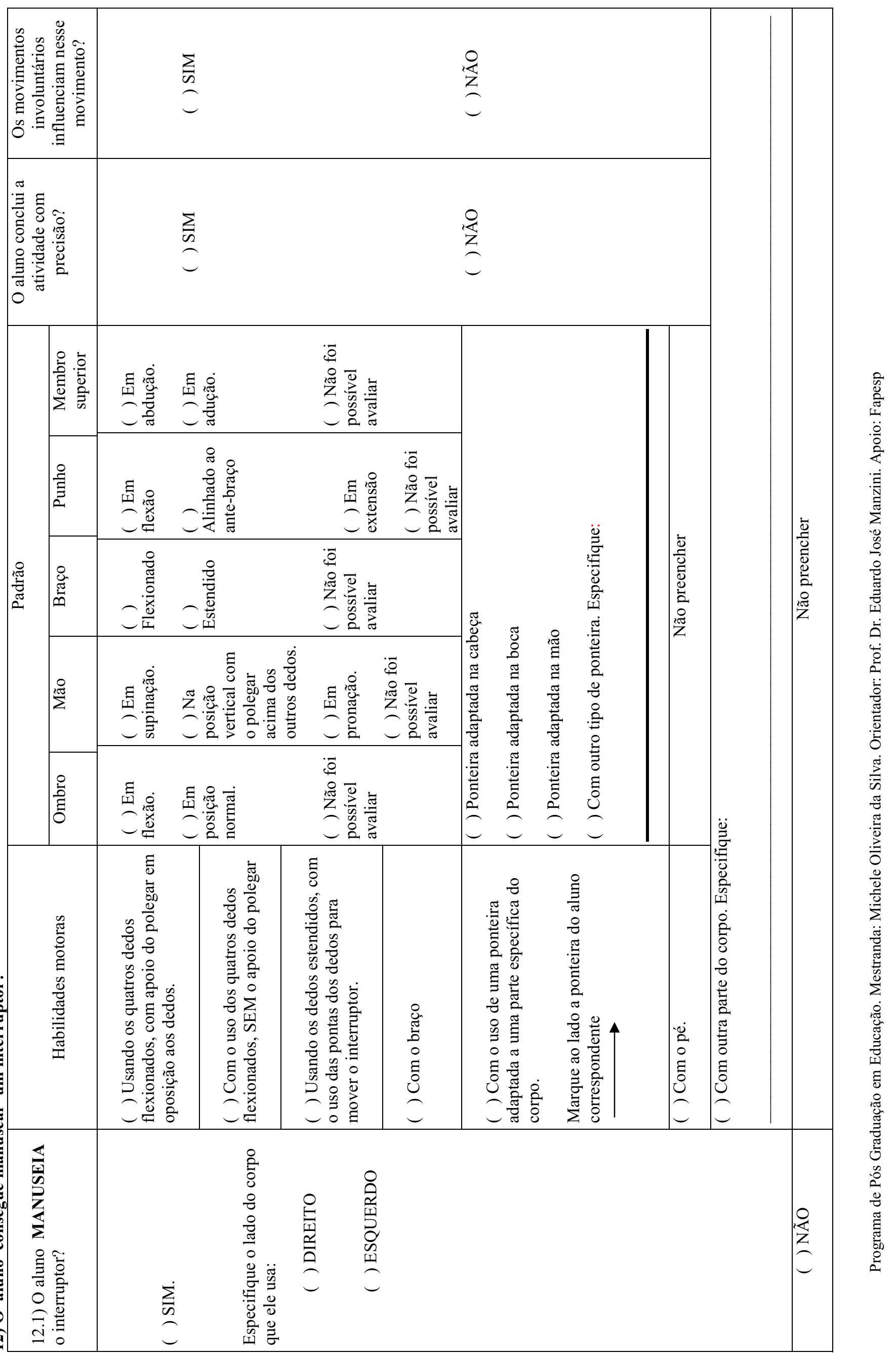




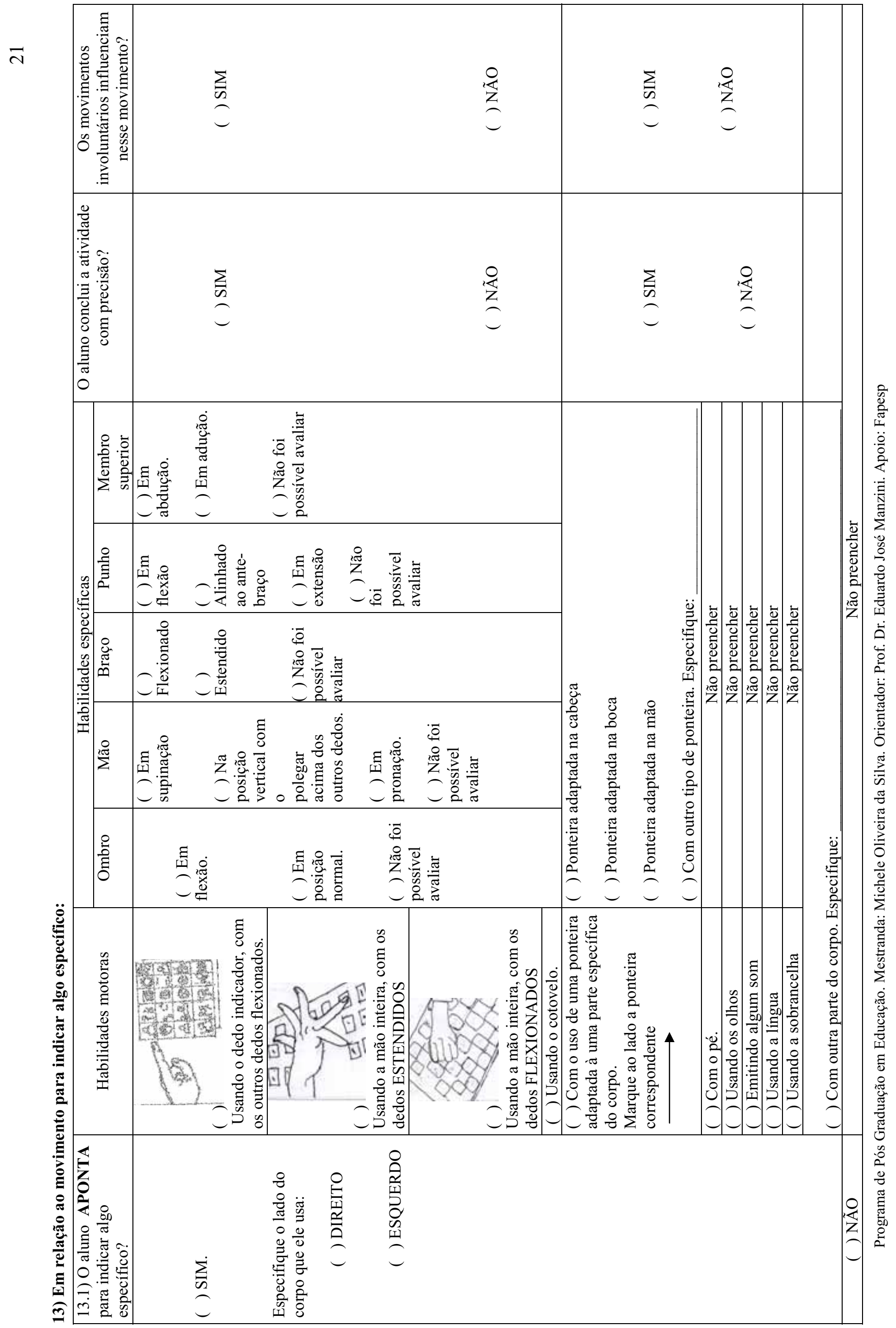


ส

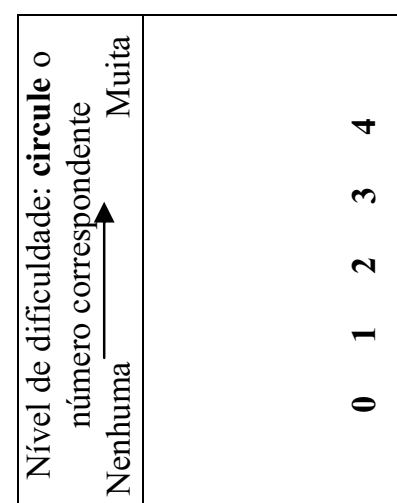

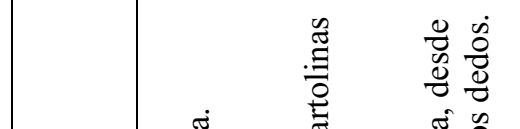

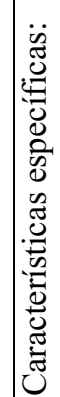

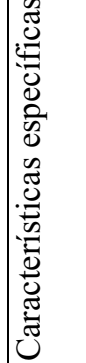

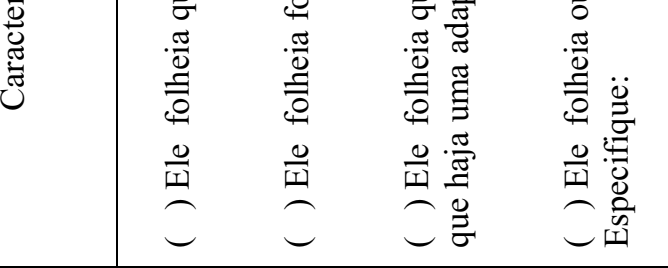
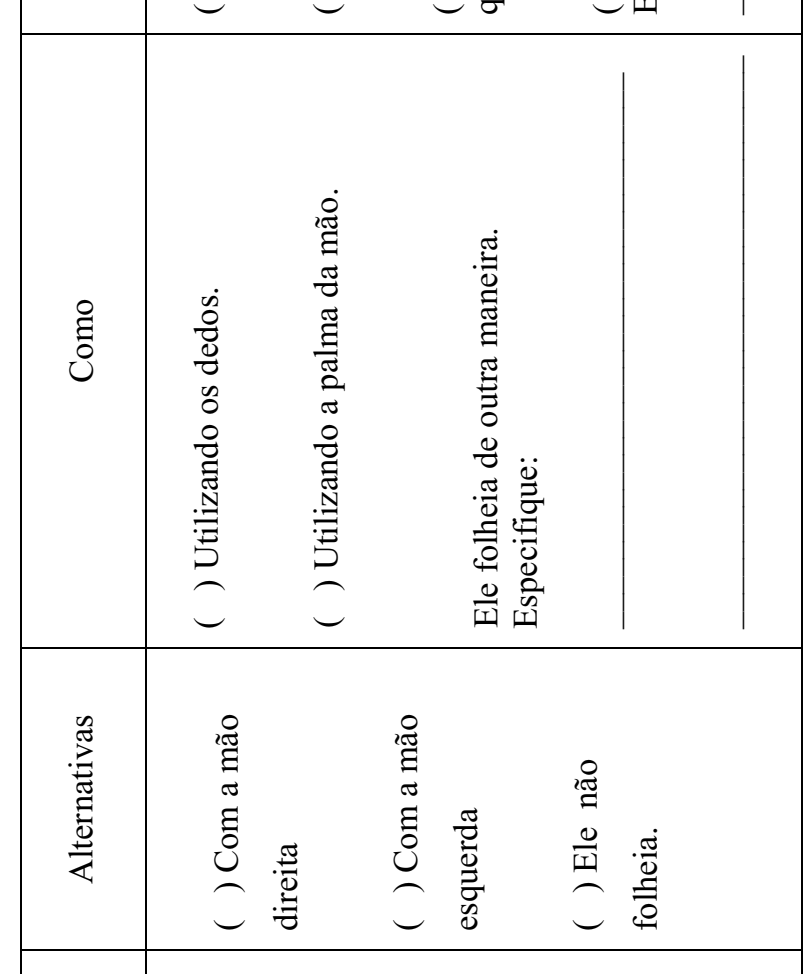

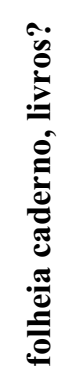
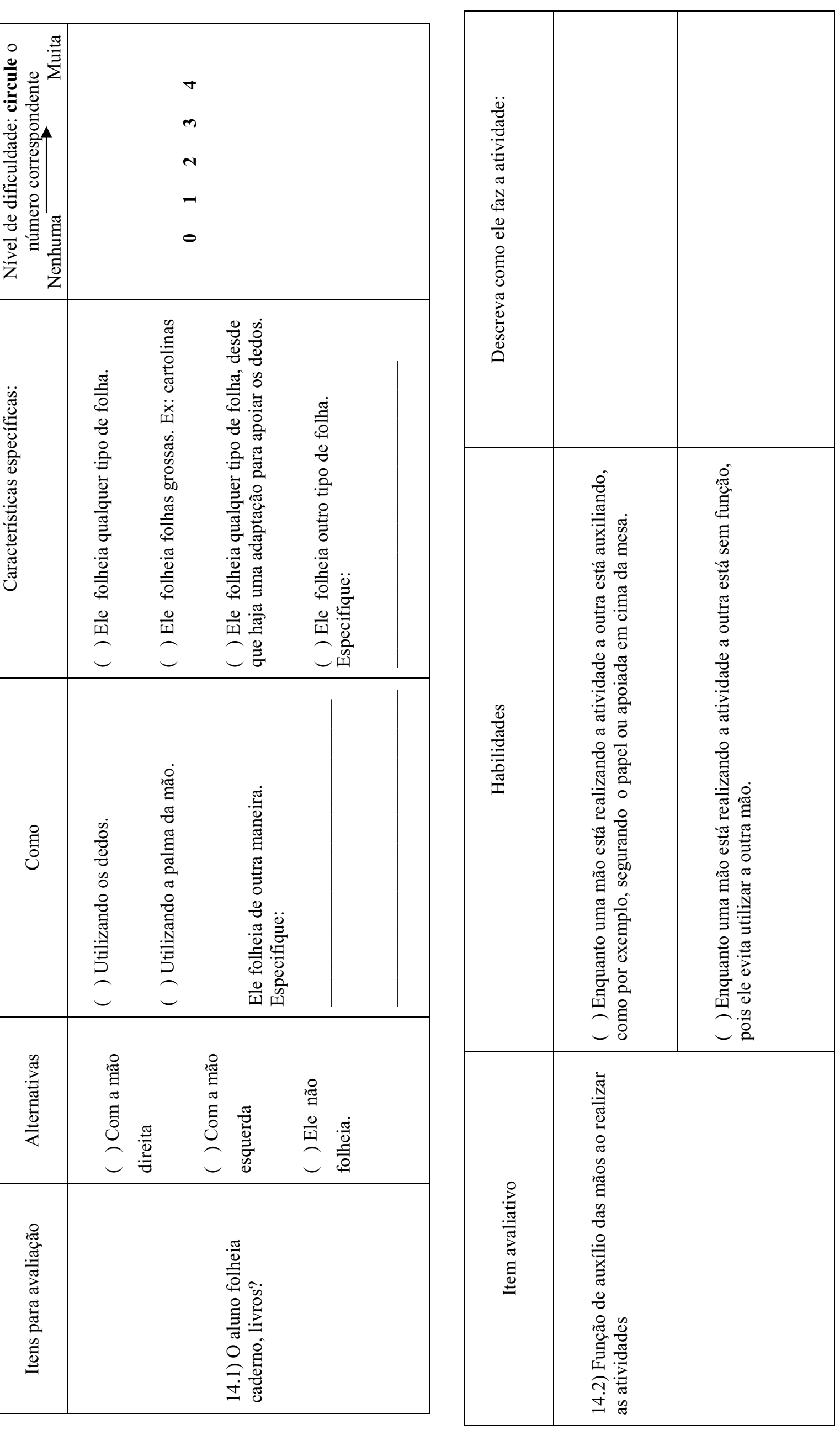

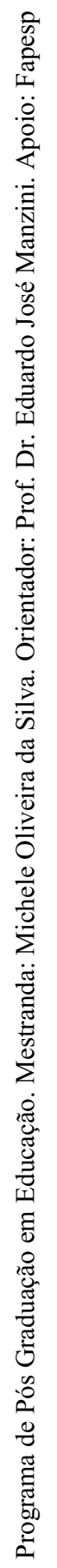


$\pi$

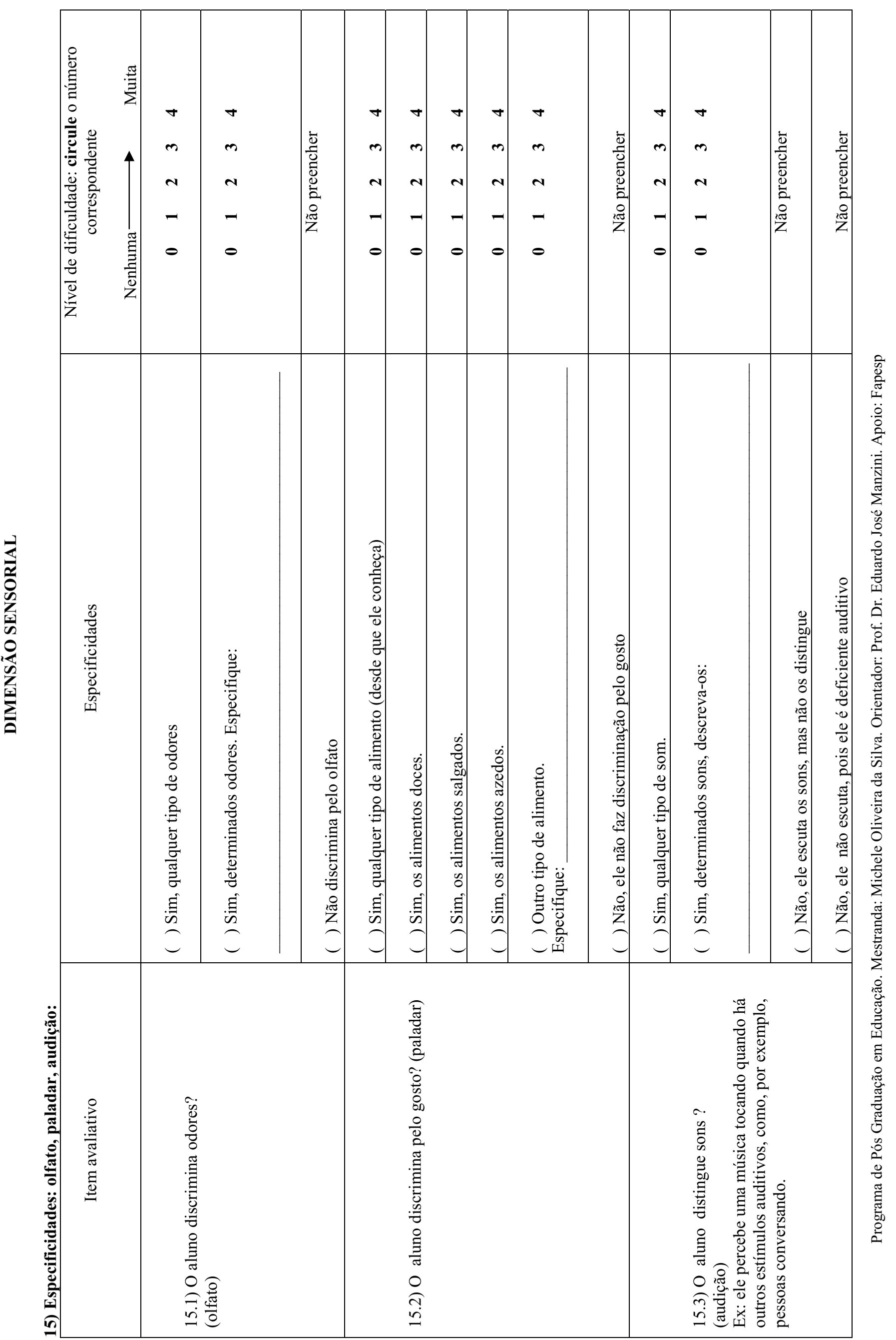




\begin{tabular}{|c|c|c|c|c|c|c|}
\hline 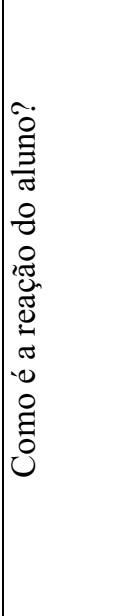 & 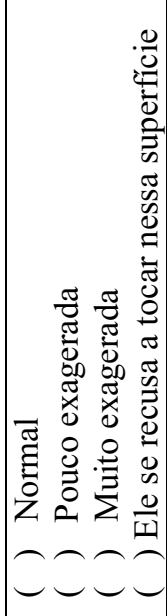 & 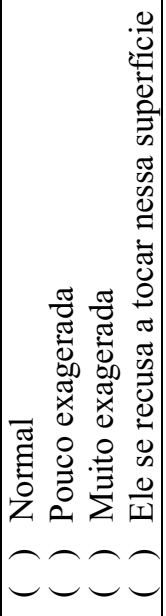 & 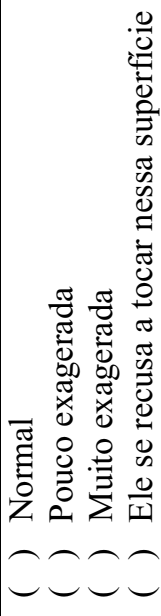 & 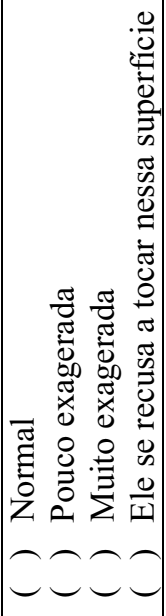 & 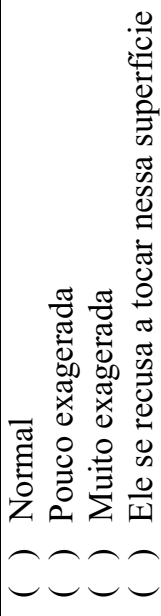 & 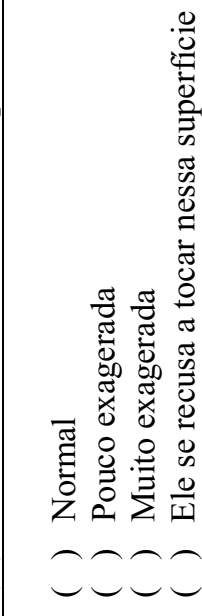 \\
\hline 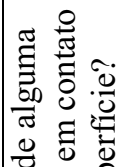 & 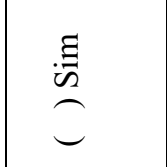 & $\stackrel{\Xi}{\stackrel{\Xi}{\complement}}$ & 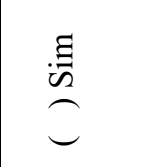 & 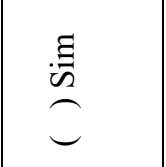 & $\stackrel{\Xi}{\check{\overbrace{}}}$ & 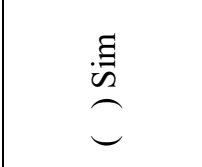 \\
\hline 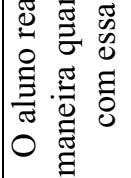 & 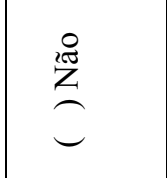 & 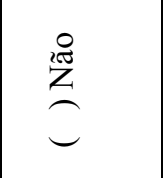 & $\stackrel{\text { Z̃ }}{\text { Z }}$ & 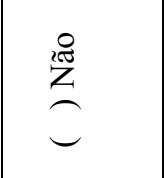 & $\stackrel{\substack{\text { Z } \\
\hdashline}}{\smile}$ & $\overbrace{\substack{\text { Z } \\
\hdashline}}^{\mathfrak{C}}$ \\
\hline $\begin{array}{l}0 \\
0 \\
0 \\
.0 \\
0 \\
0 \\
0\end{array}$ & $\stackrel{\Xi}{\stackrel{\Xi}{\check{2}}}$ & $\stackrel{\Xi}{\stackrel{\Xi}{\check{C}}}$ & $\stackrel{\Xi}{\check{C}}$ & $\stackrel{\Xi}{\mathfrak{\Xi}}$ & $\stackrel{\Xi}{\stackrel{\Xi}{\Xi}}$ & $\stackrel{\Xi}{\mathfrak{E}}$ \\
\hline 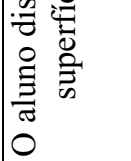 & $\underbrace{}_{\substack{\text { Z̃ } \\
\text { ? }}}$ & 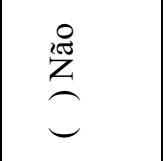 & 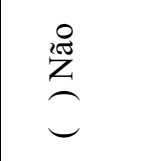 & 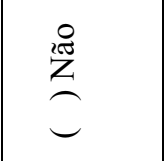 & $\stackrel{\substack{\text { Z̃ } \\
\text { Z }}}{\smile}$ & 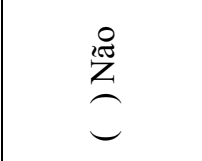 \\
\hline $\begin{array}{l}0 \\
0 \\
0 \\
0 \\
0 \\
0 \\
0\end{array}$ & $\stackrel{\Xi}{\stackrel{\Xi}{\check{C}}}$ & $\stackrel{\Xi}{\stackrel{\Xi}{\complement}}$ & $\stackrel{\Xi}{\check{E}}$ & 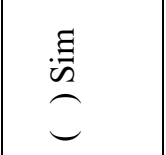 & 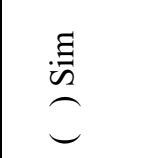 & $\stackrel{\Xi}{\mathfrak{C}}$ \\
\hline 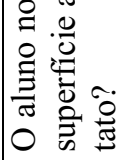 & $\underbrace{}_{\substack{\text { Z } \\
\hdashline}}$ & $\overbrace{\substack{\text { Z } \\
\hdashline}}^{\mathfrak{C}}$ & $\overbrace{}^{\stackrel{2}{Z}}$ & $\stackrel{\substack{\text { Z } \\
\text { 乙 }}}{\smile}$ & $\stackrel{\substack{\text { Z } \\
\text { 己 }}}{\smile}$ & $\underbrace{\mathfrak{C}}_{\substack{\text { Z̃ } \\
\hdashline}}$ \\
\hline 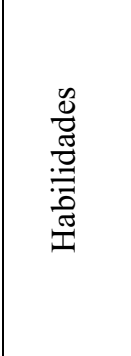 & 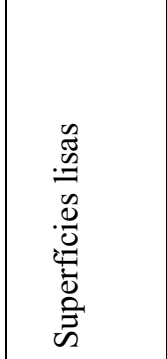 & 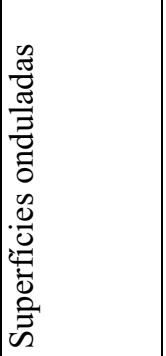 & 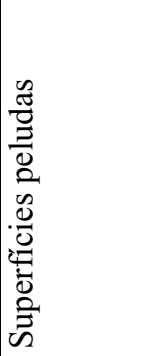 & 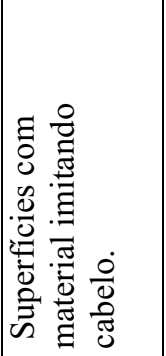 & 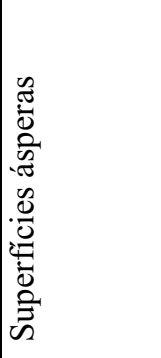 & 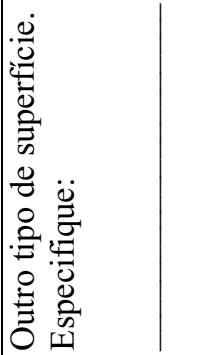 \\
\hline 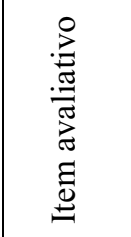 & \multicolumn{6}{|c|}{ 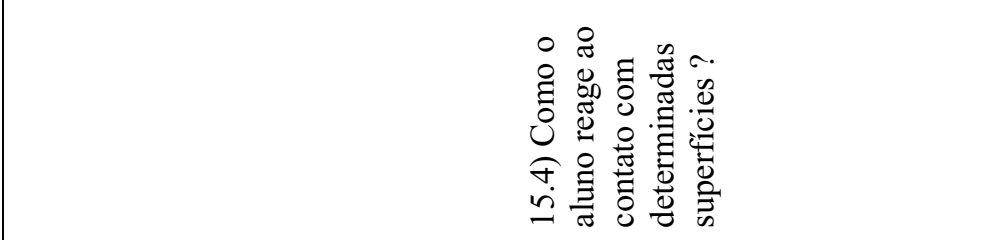 } \\
\hline
\end{tabular}

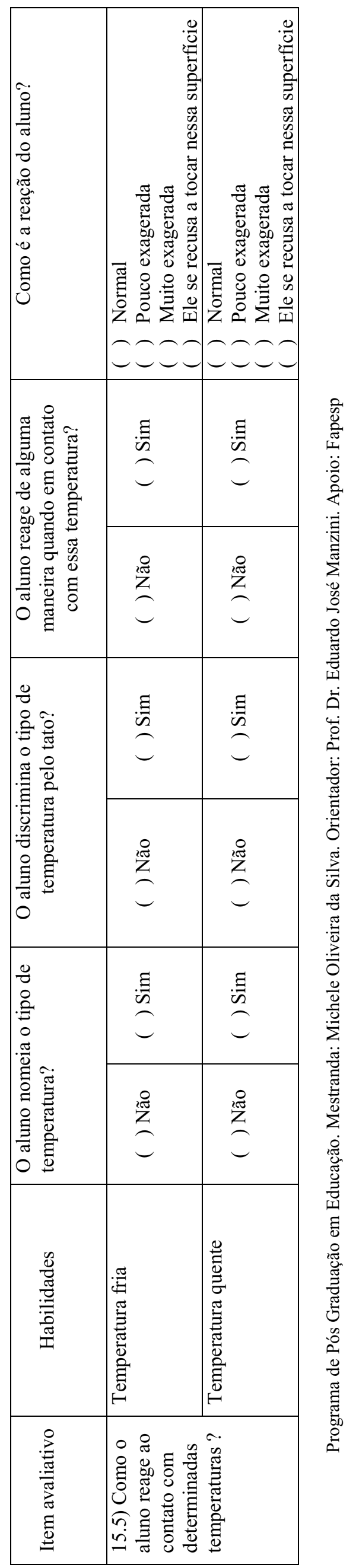




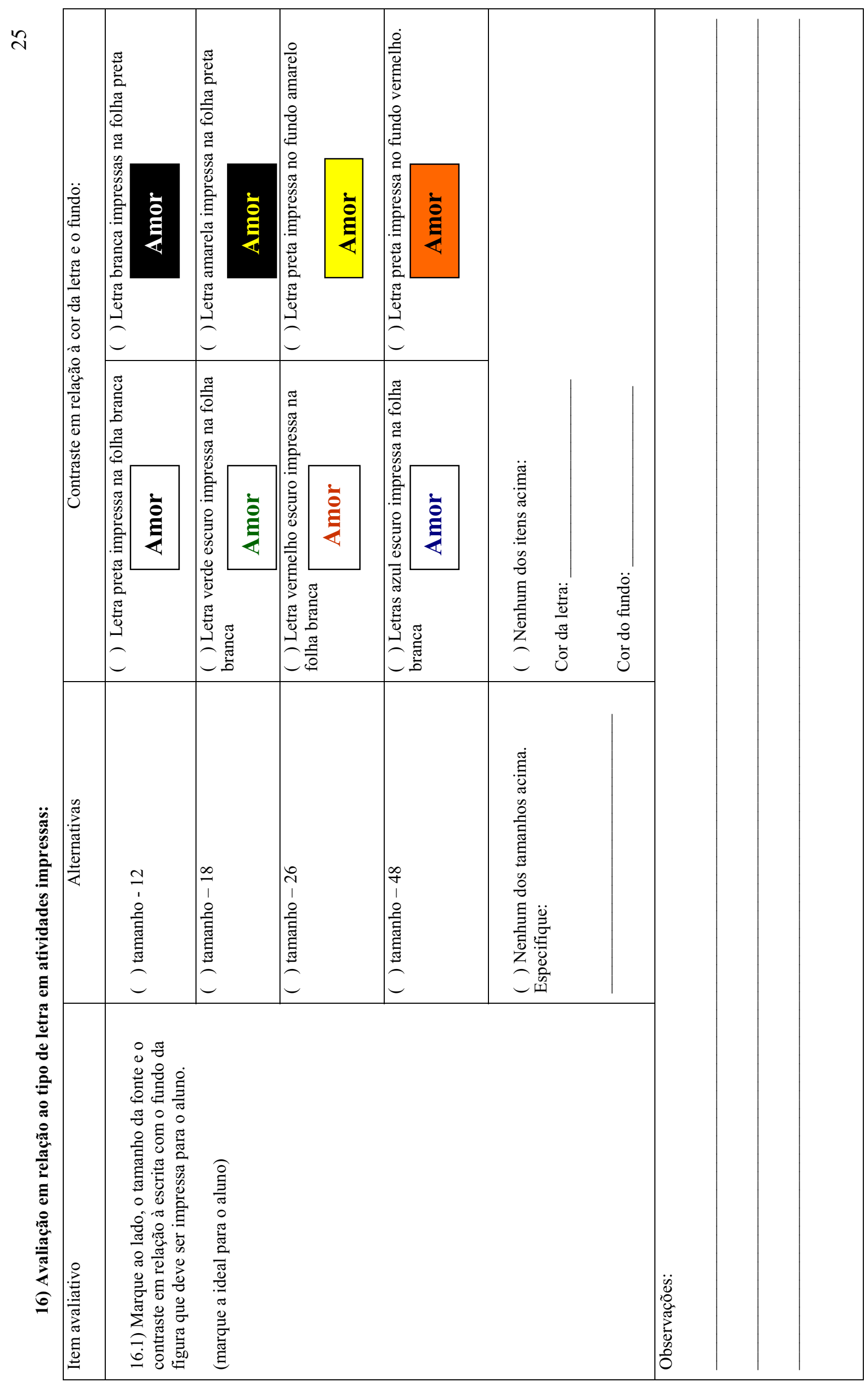

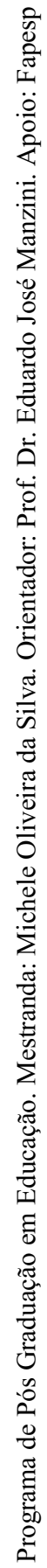


i

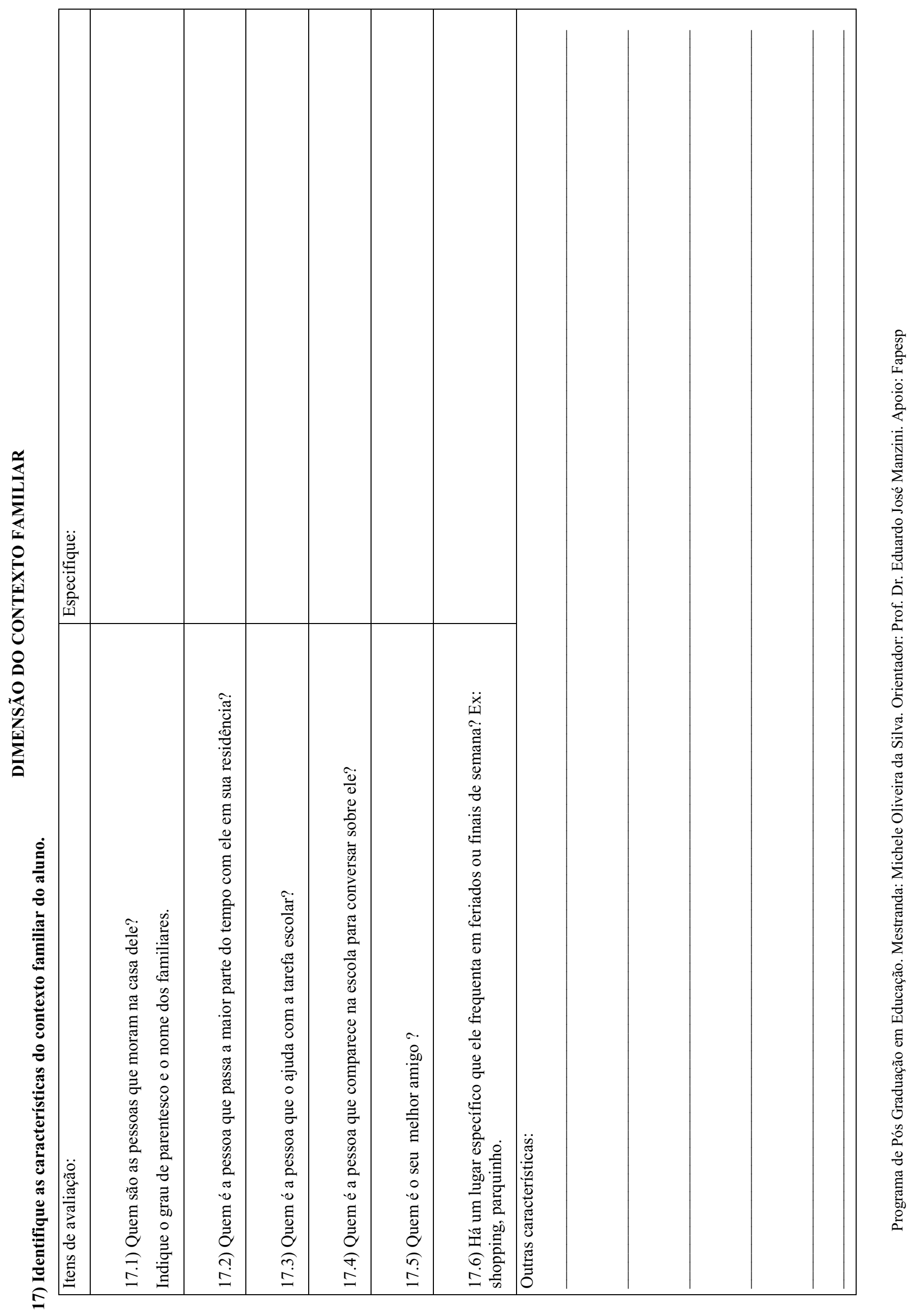


ง

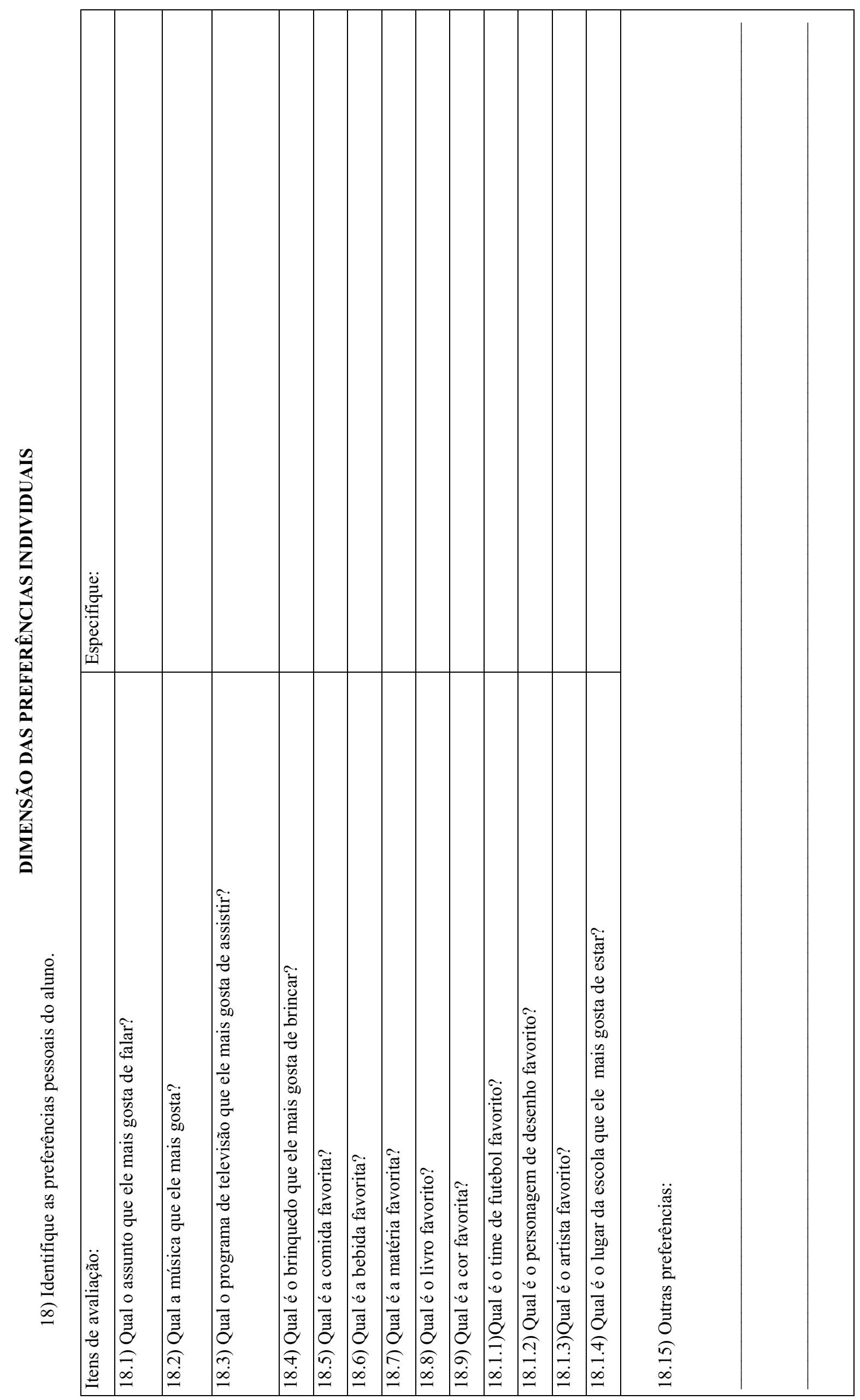

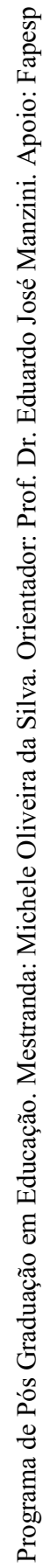


$\stackrel{\infty}{\sim}$

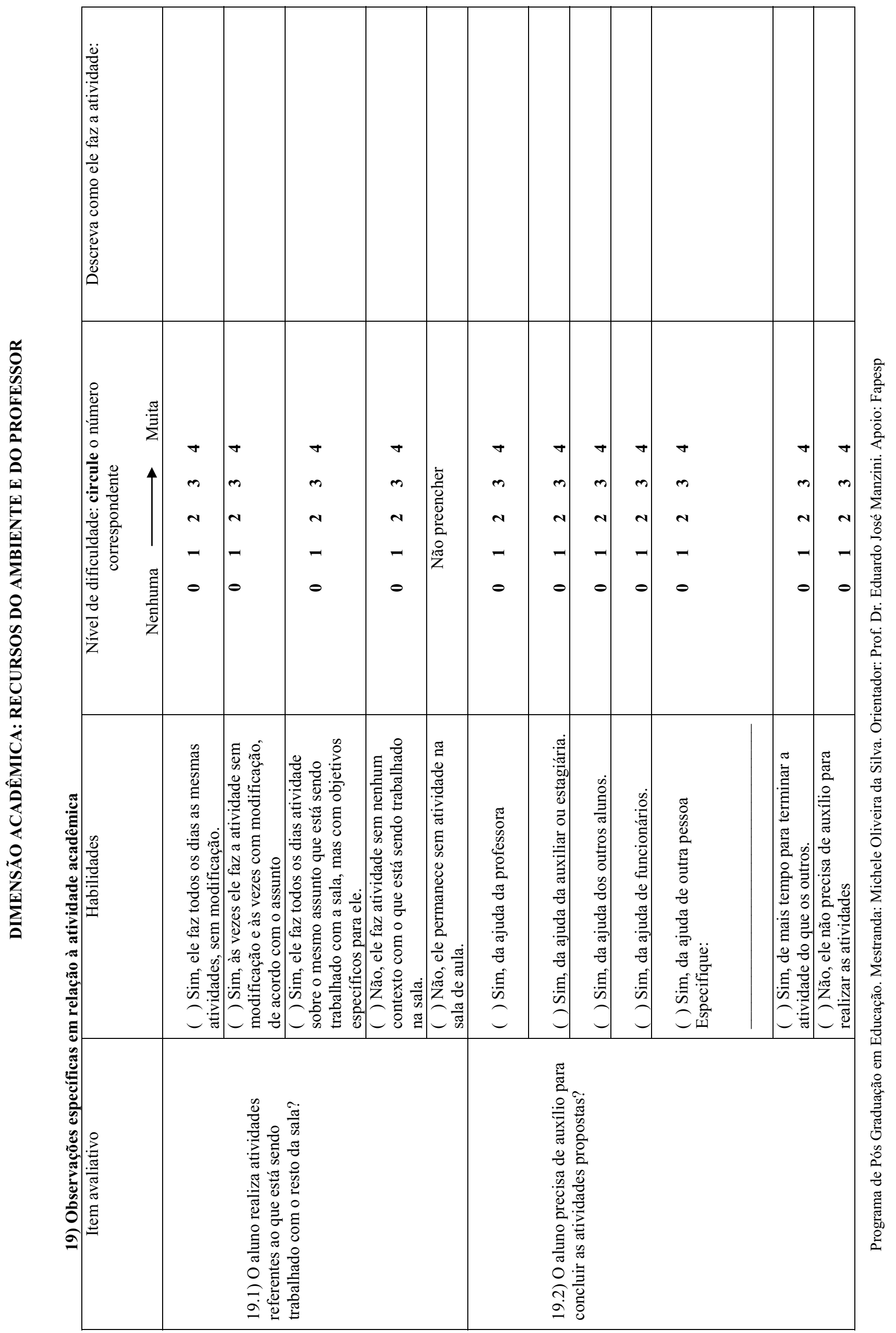




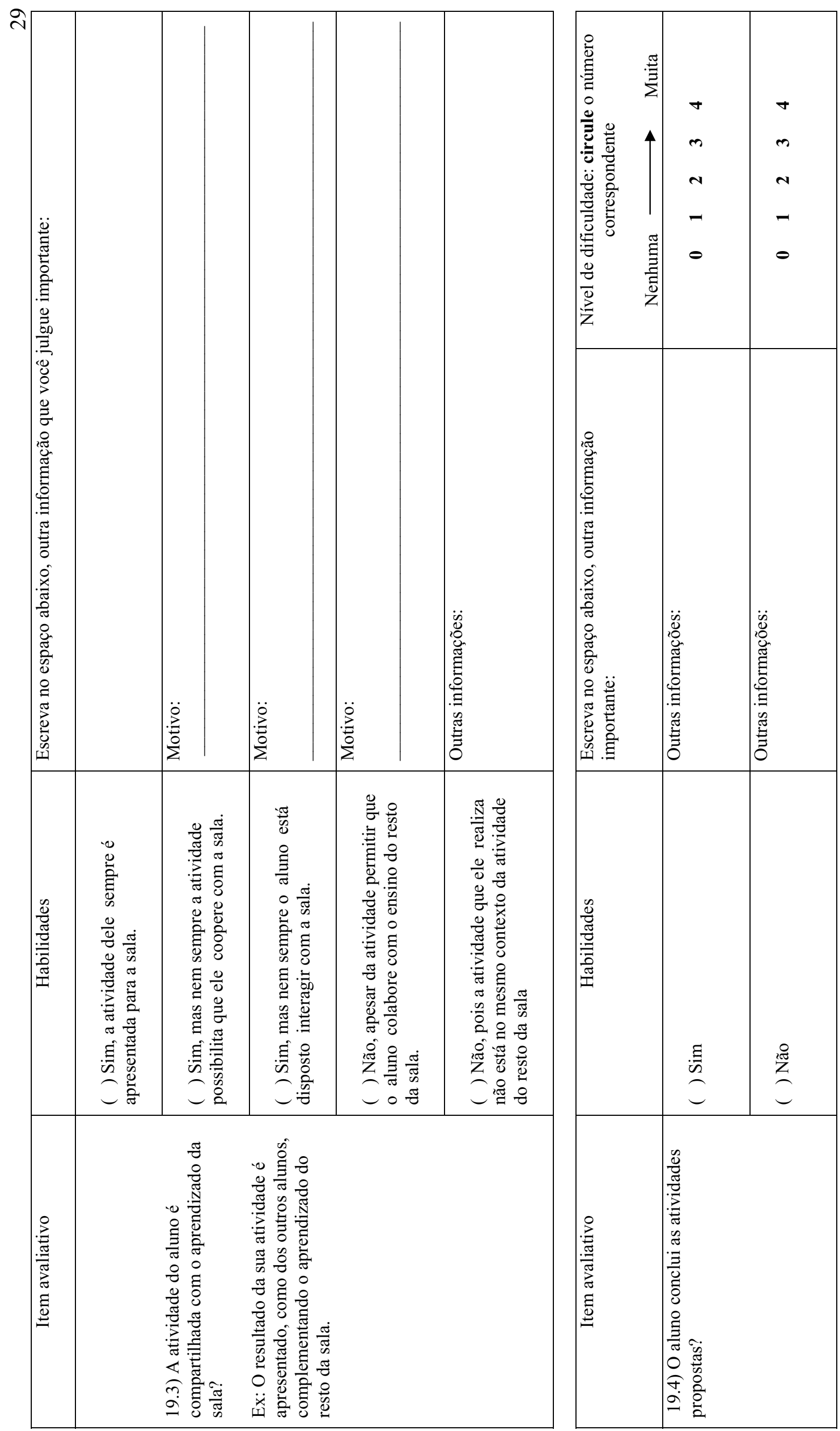

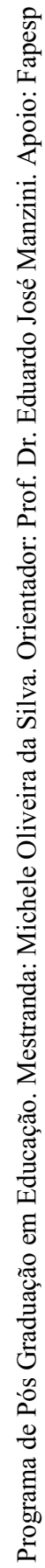




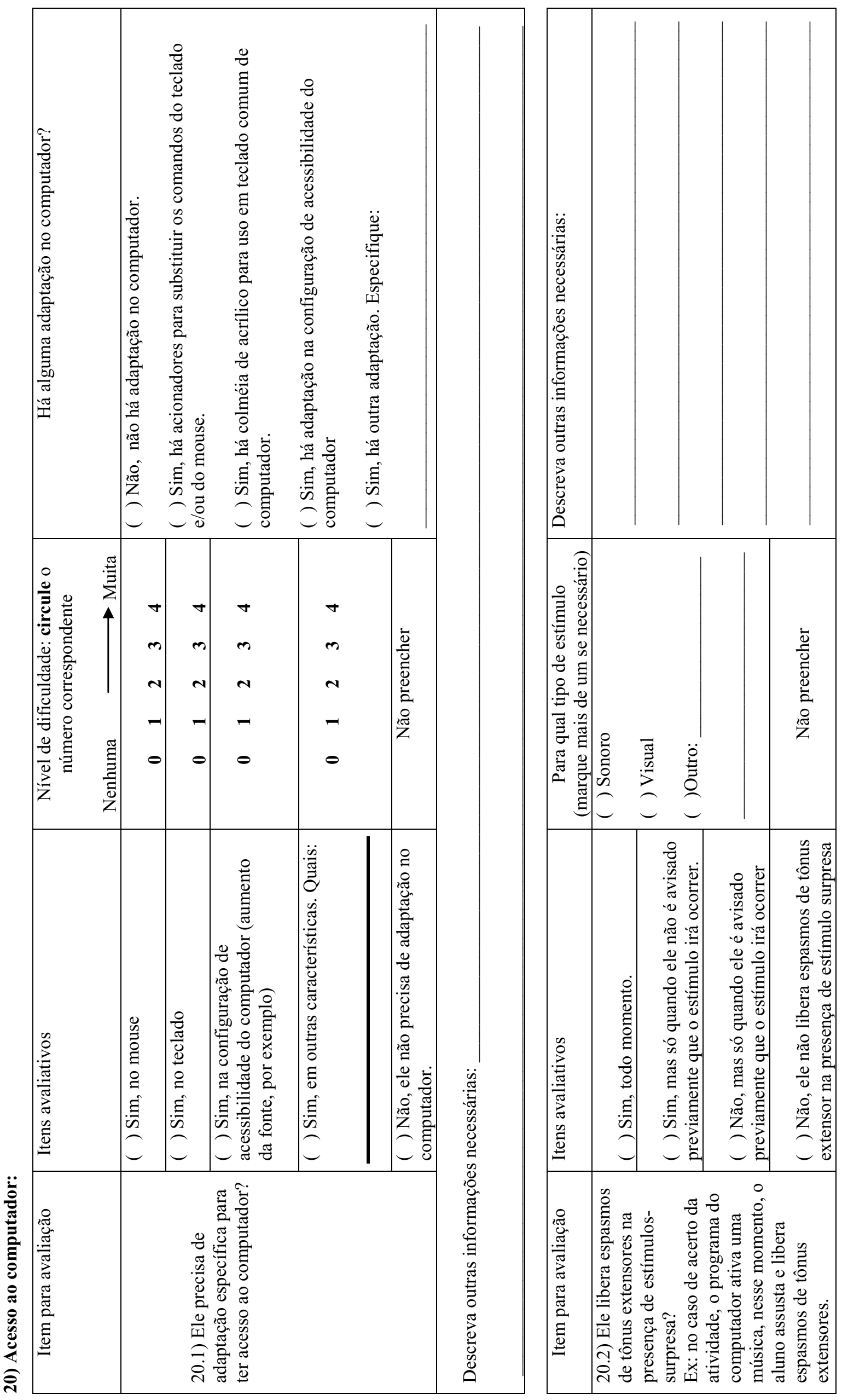




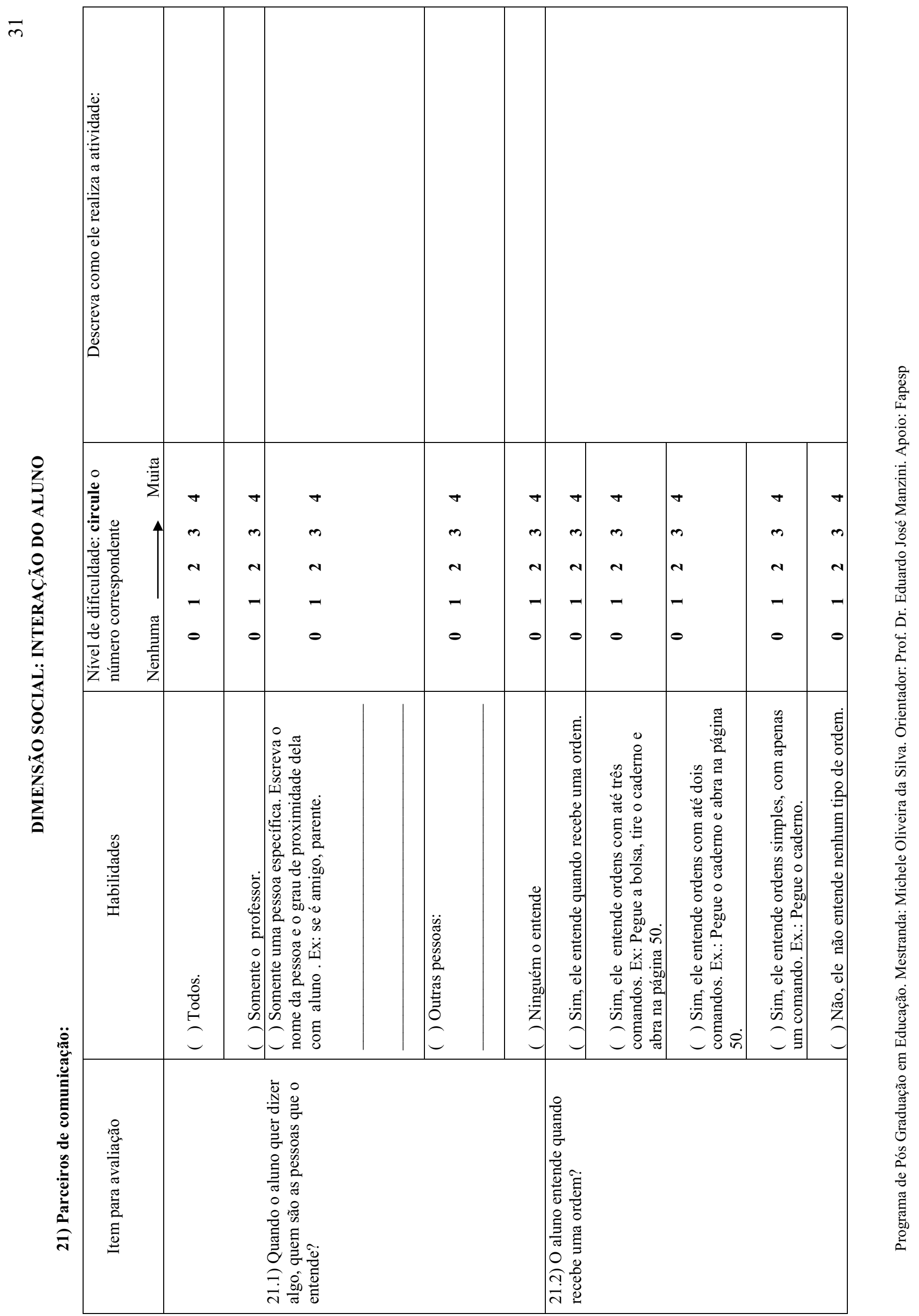


లె

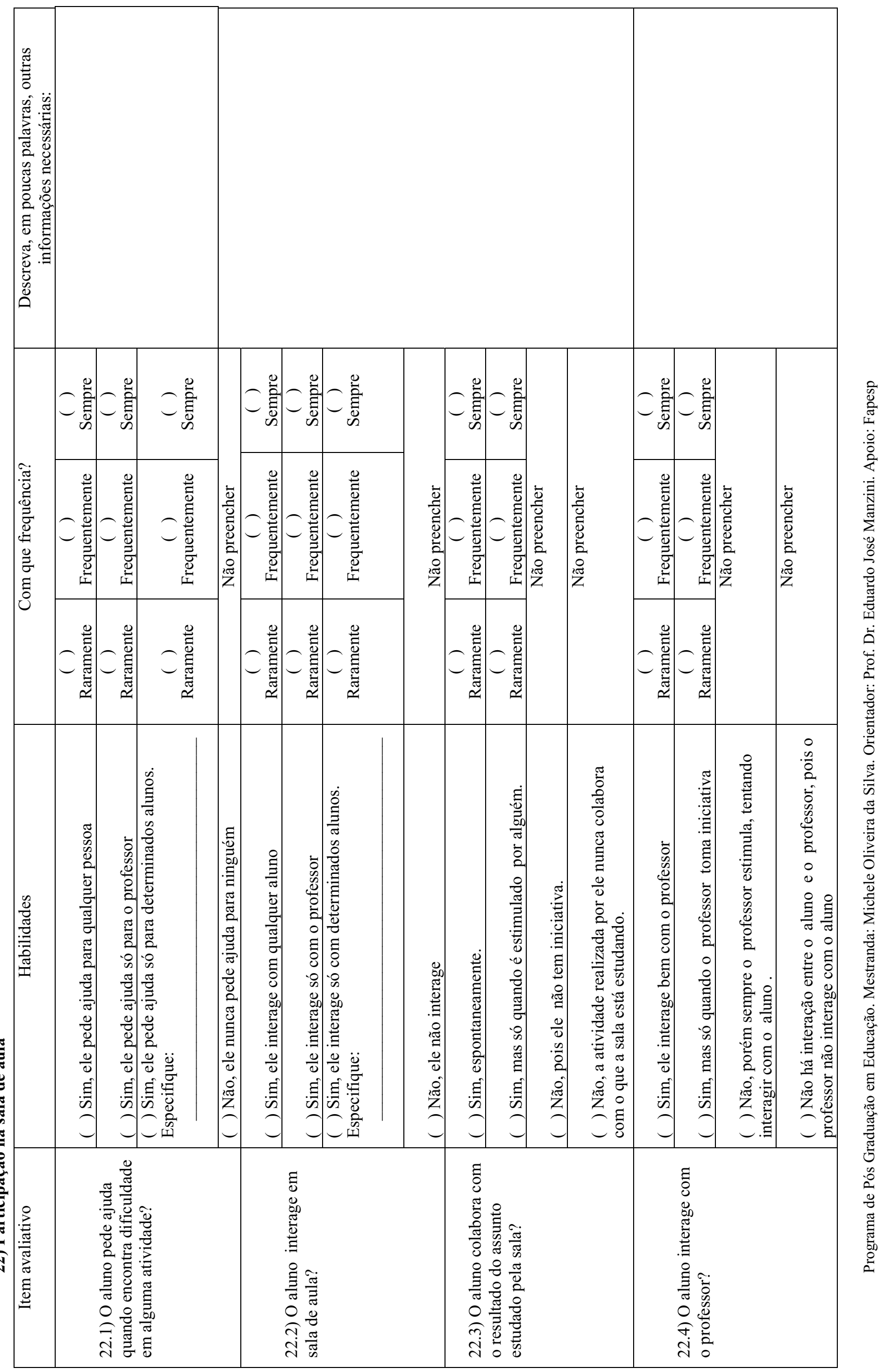




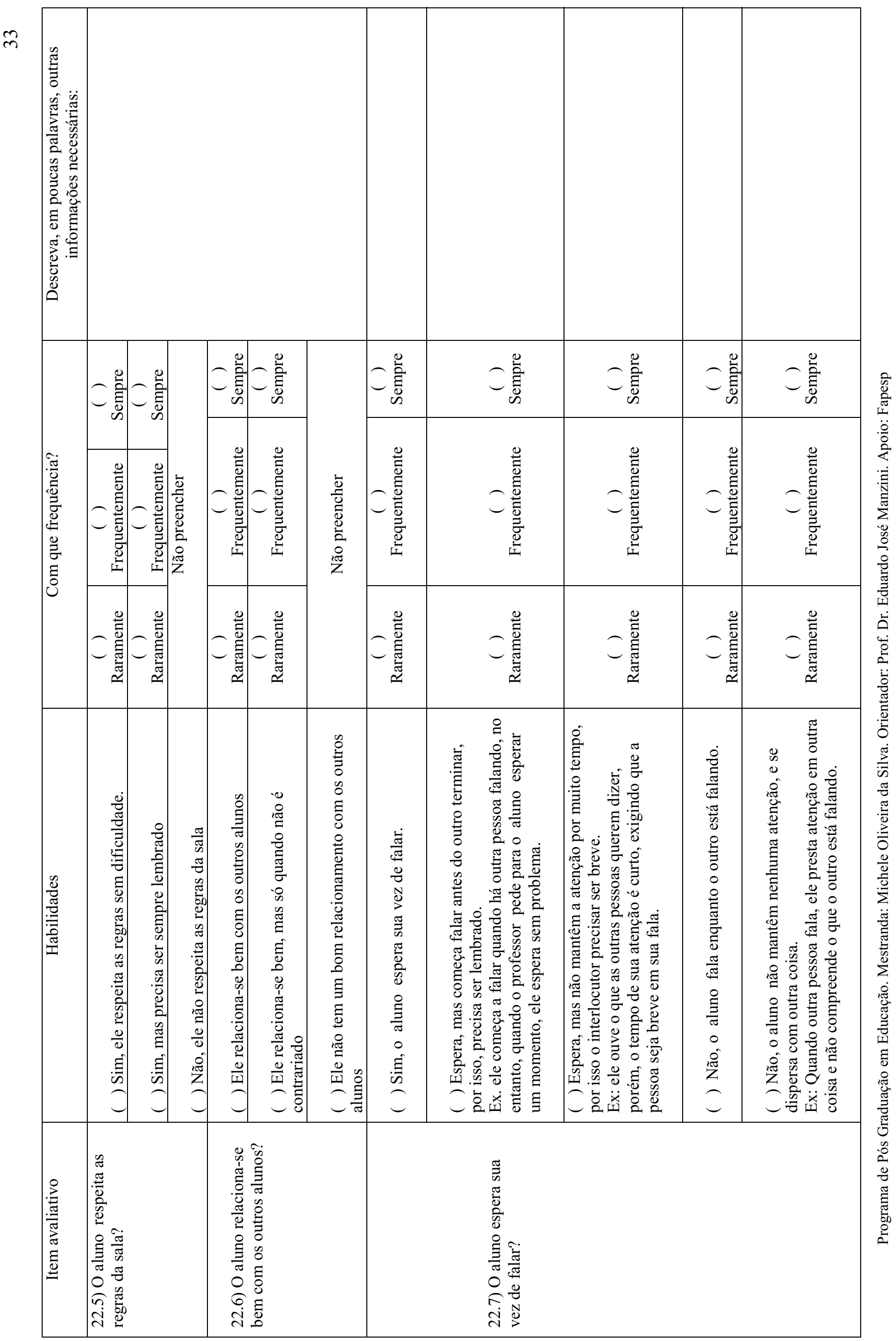




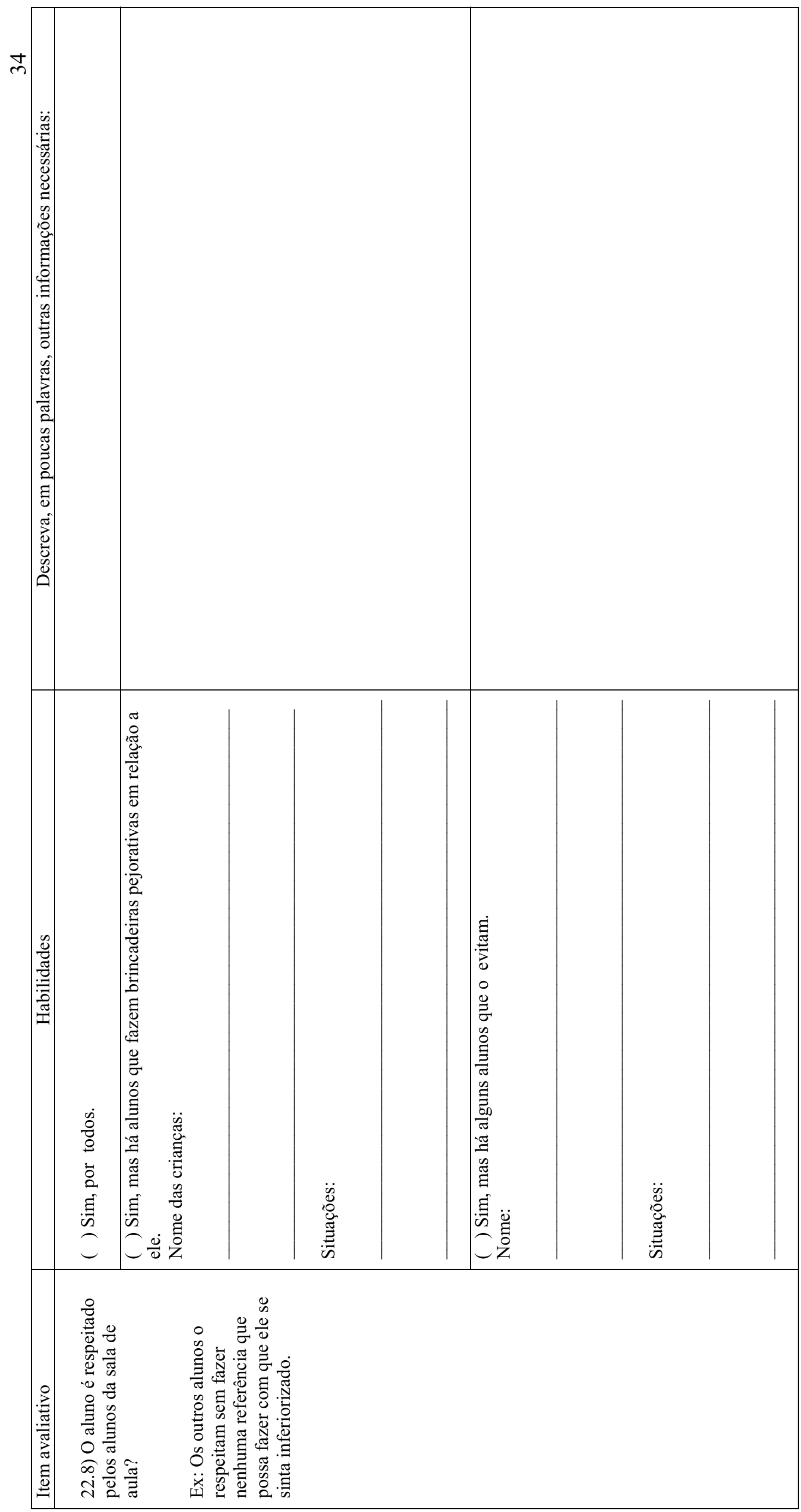




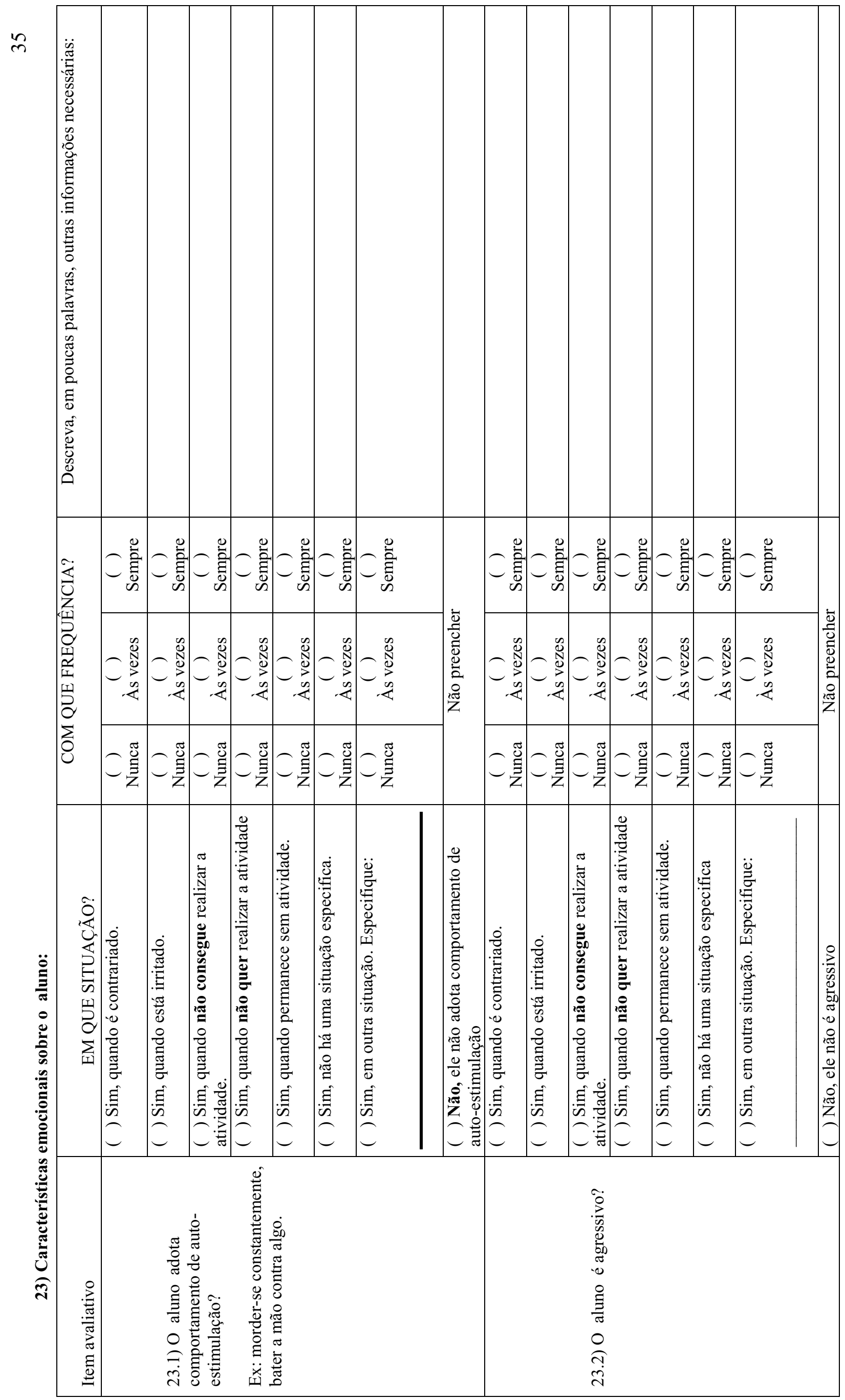

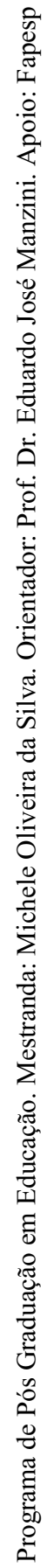




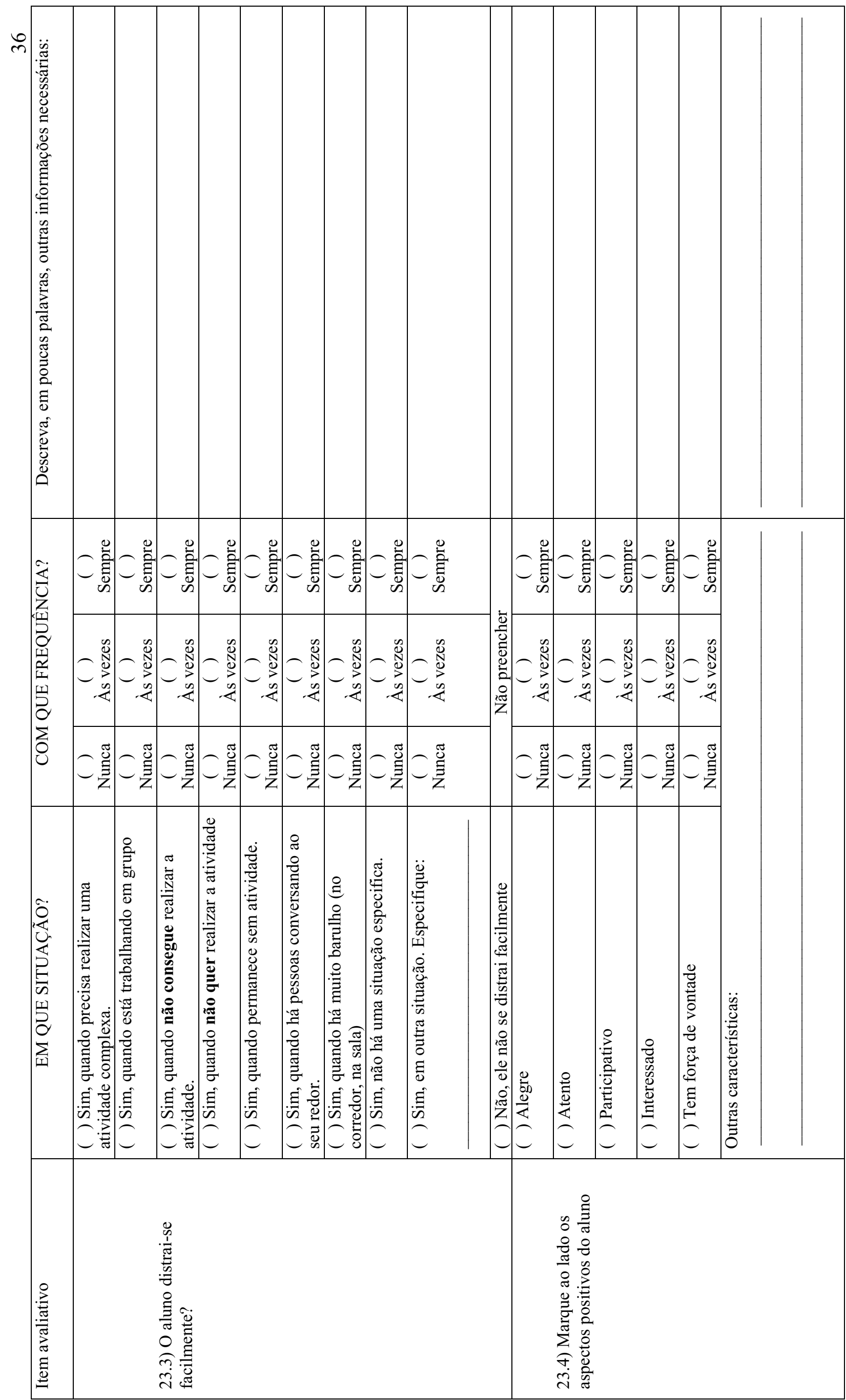

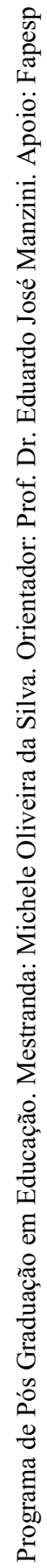




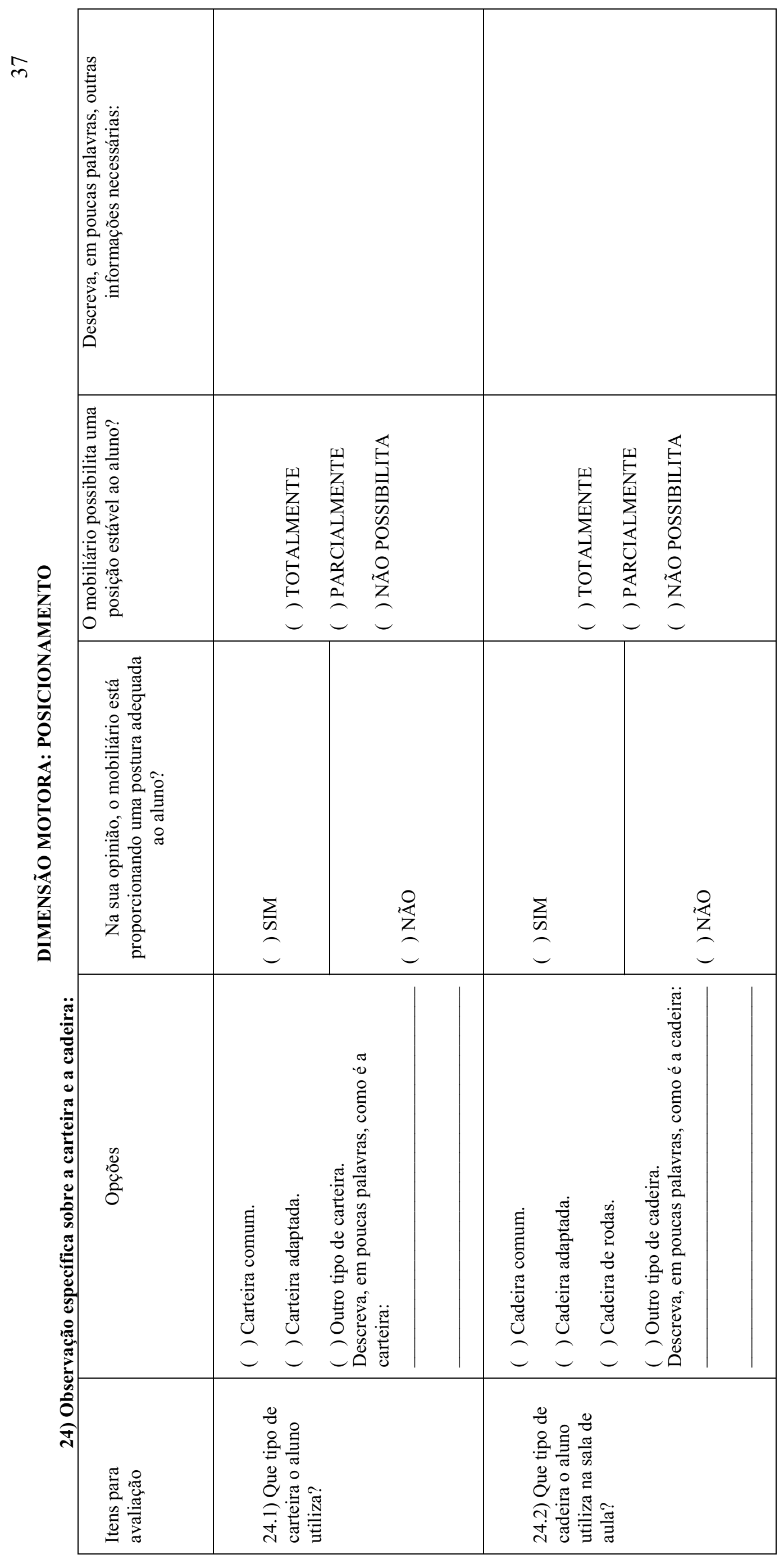

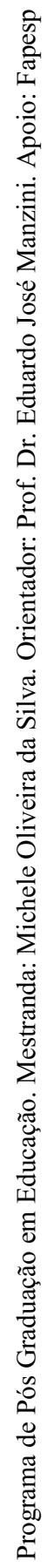


$\infty$

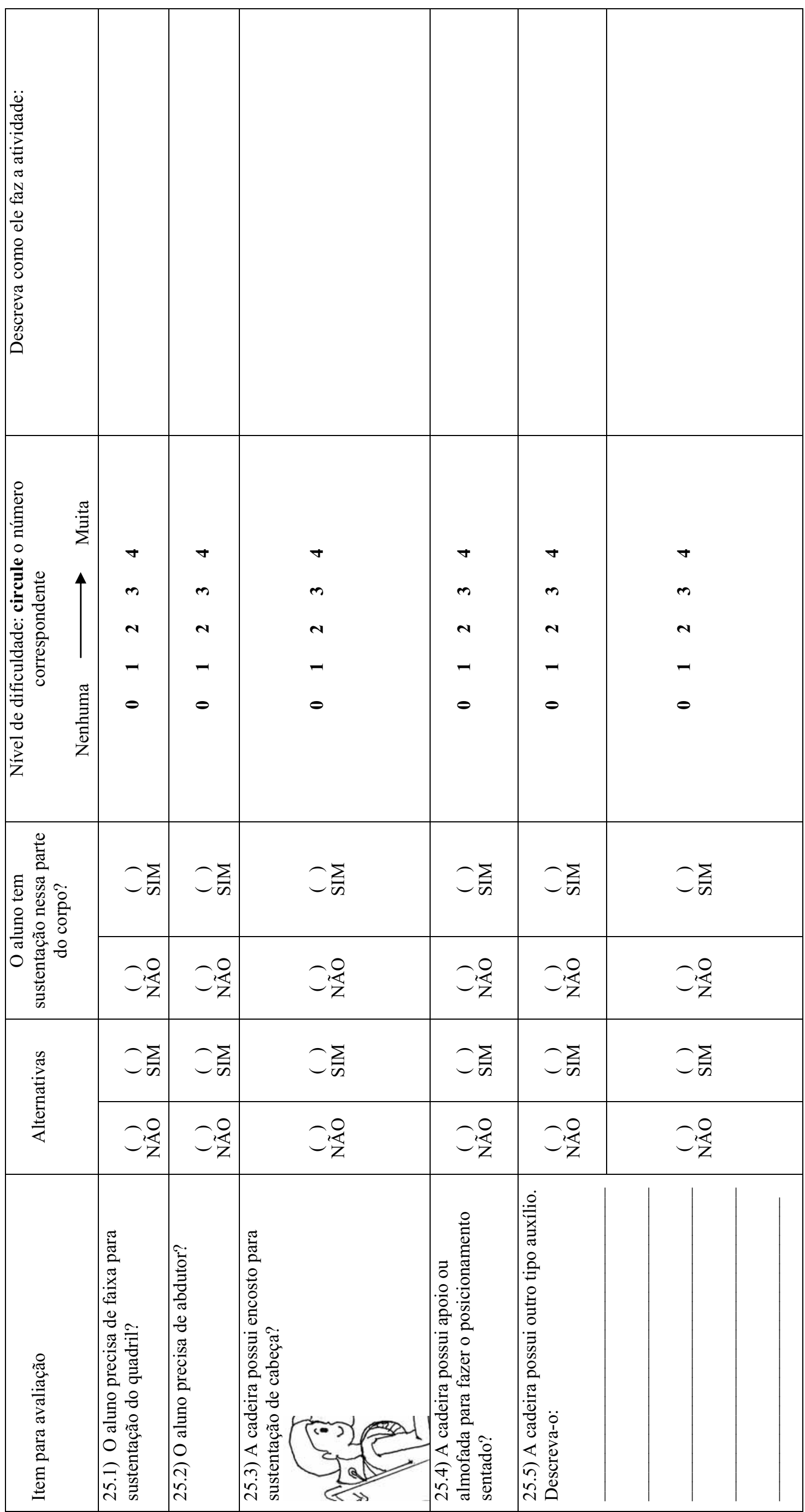


ले

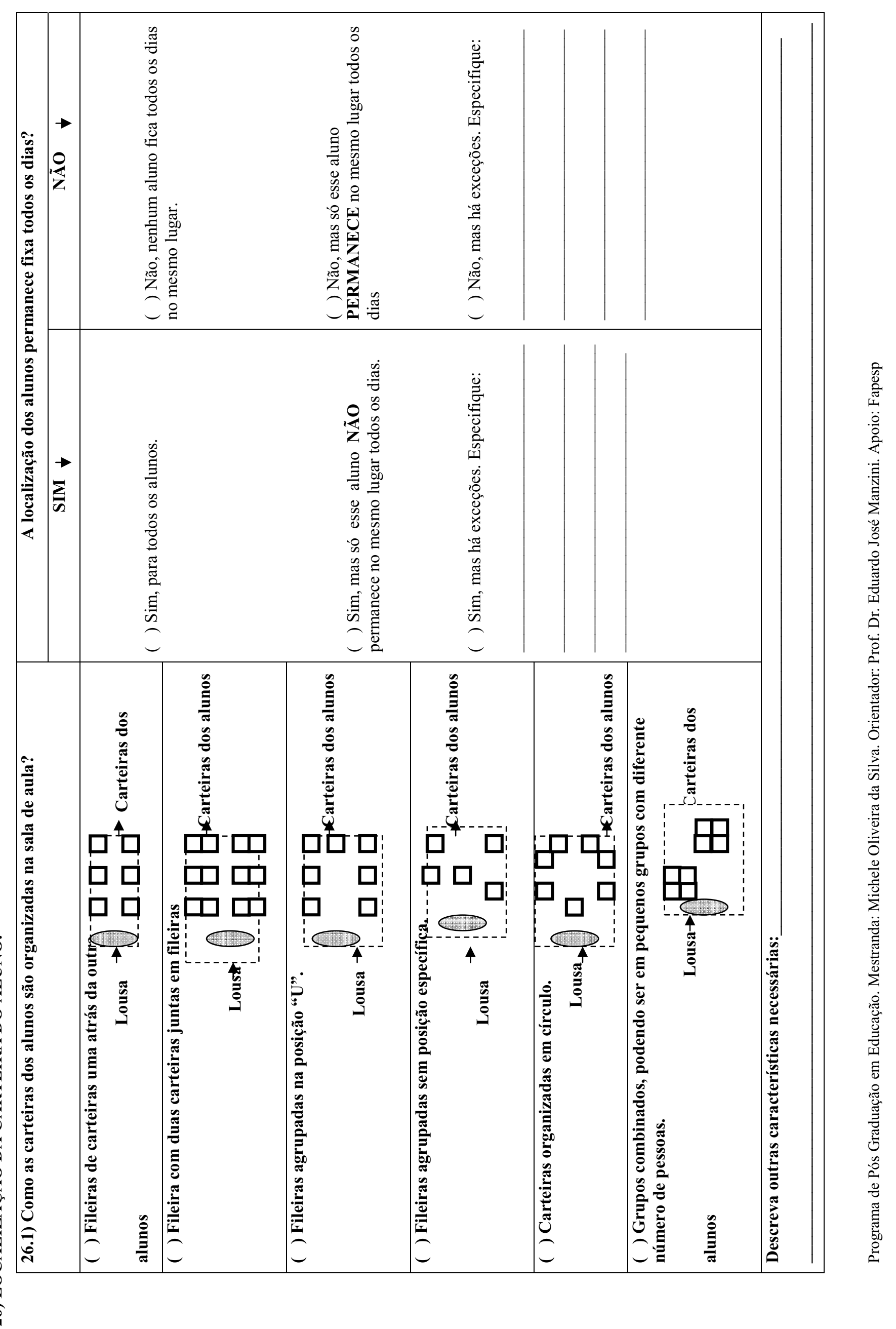


위

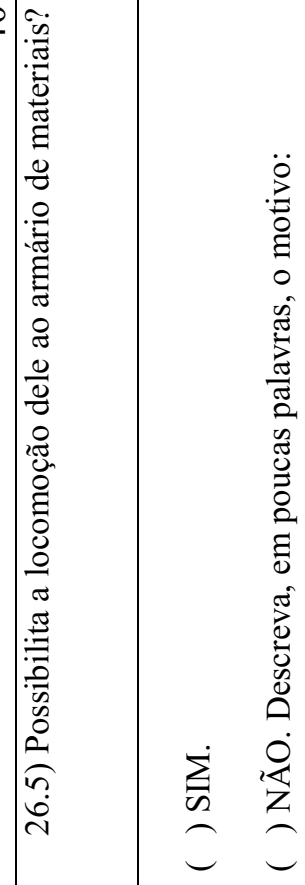

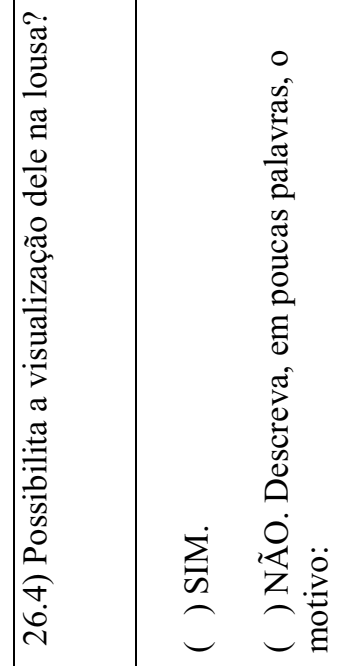

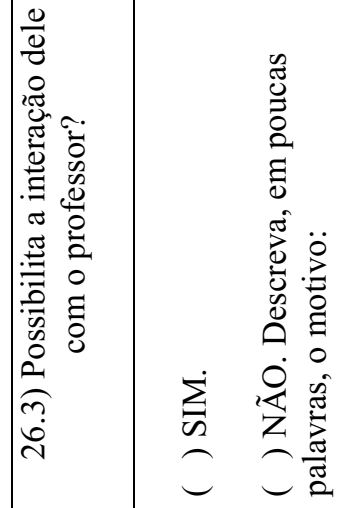

웅

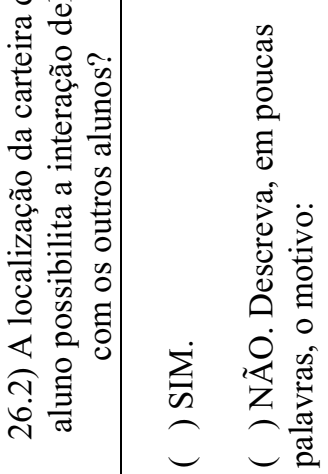




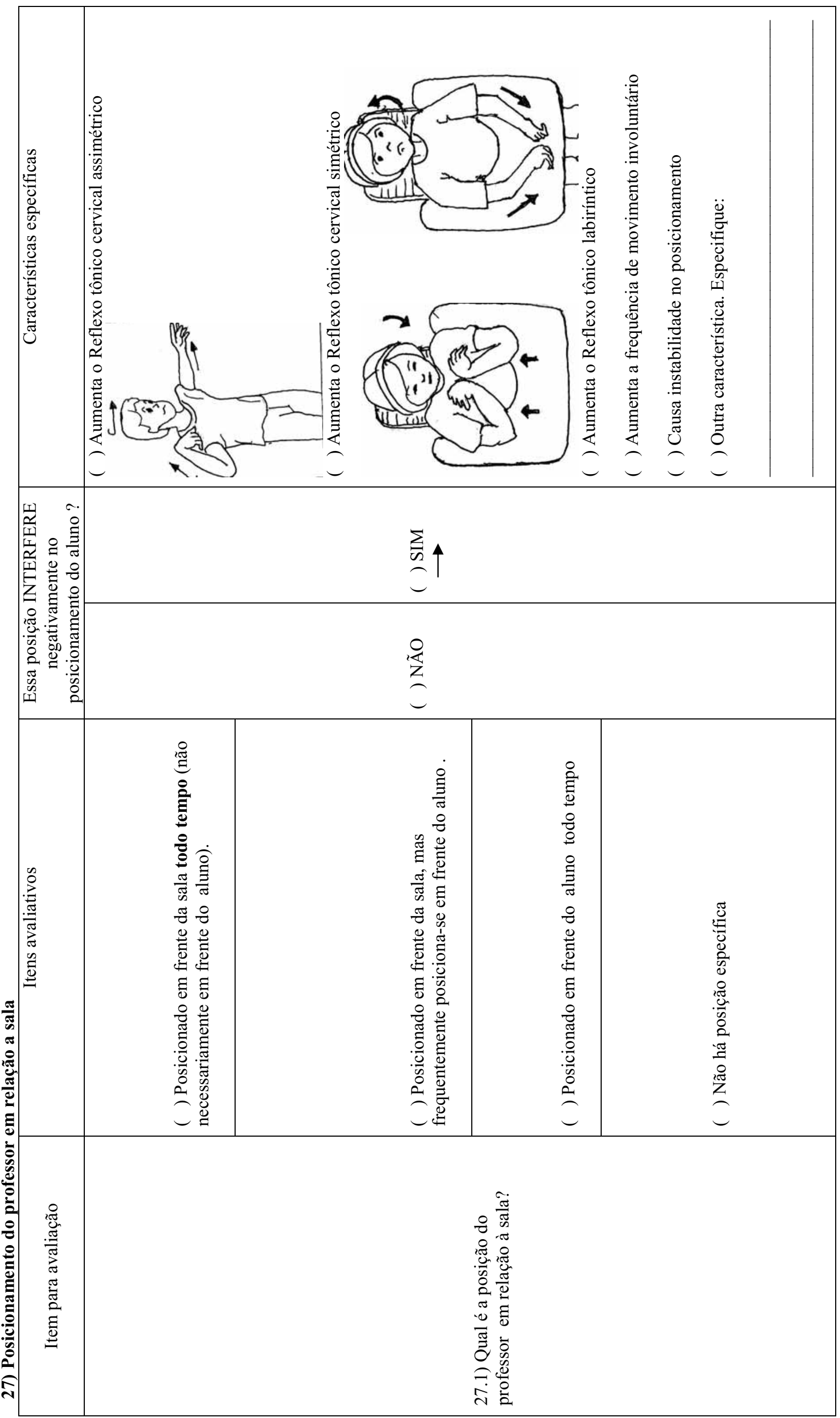




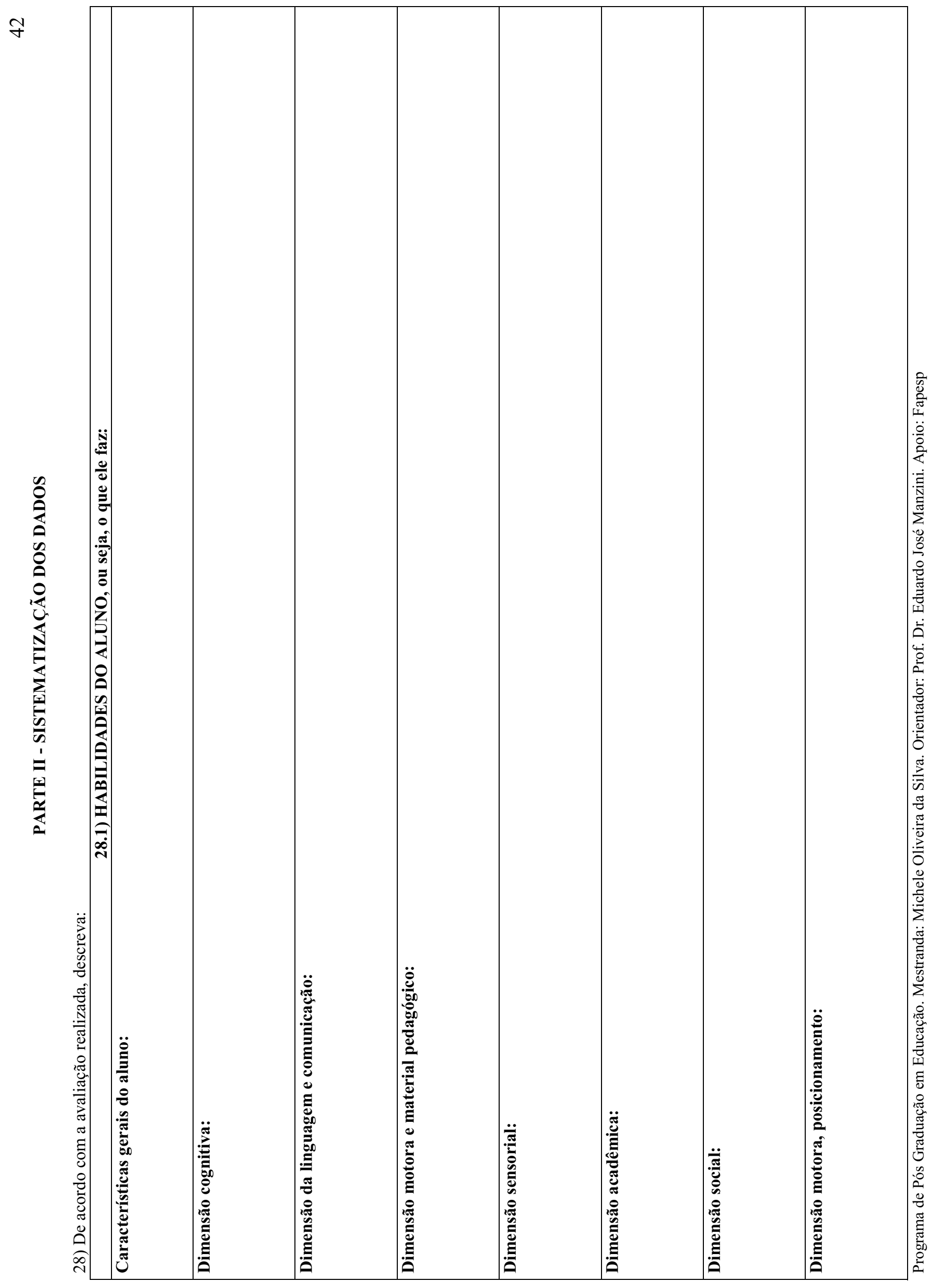



Hinll 


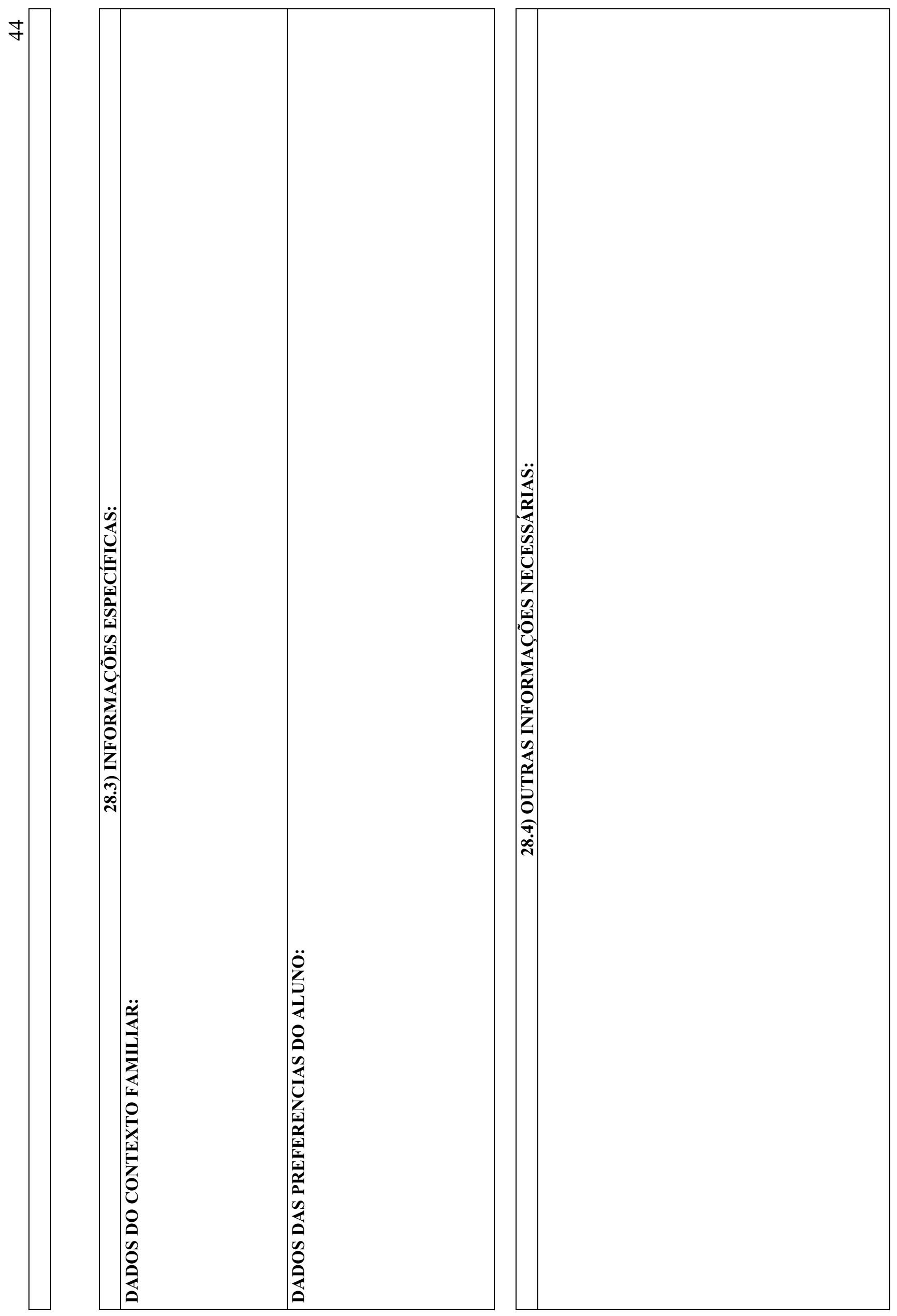

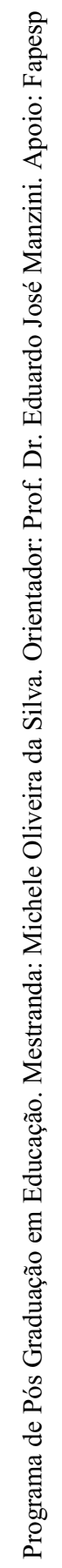


i

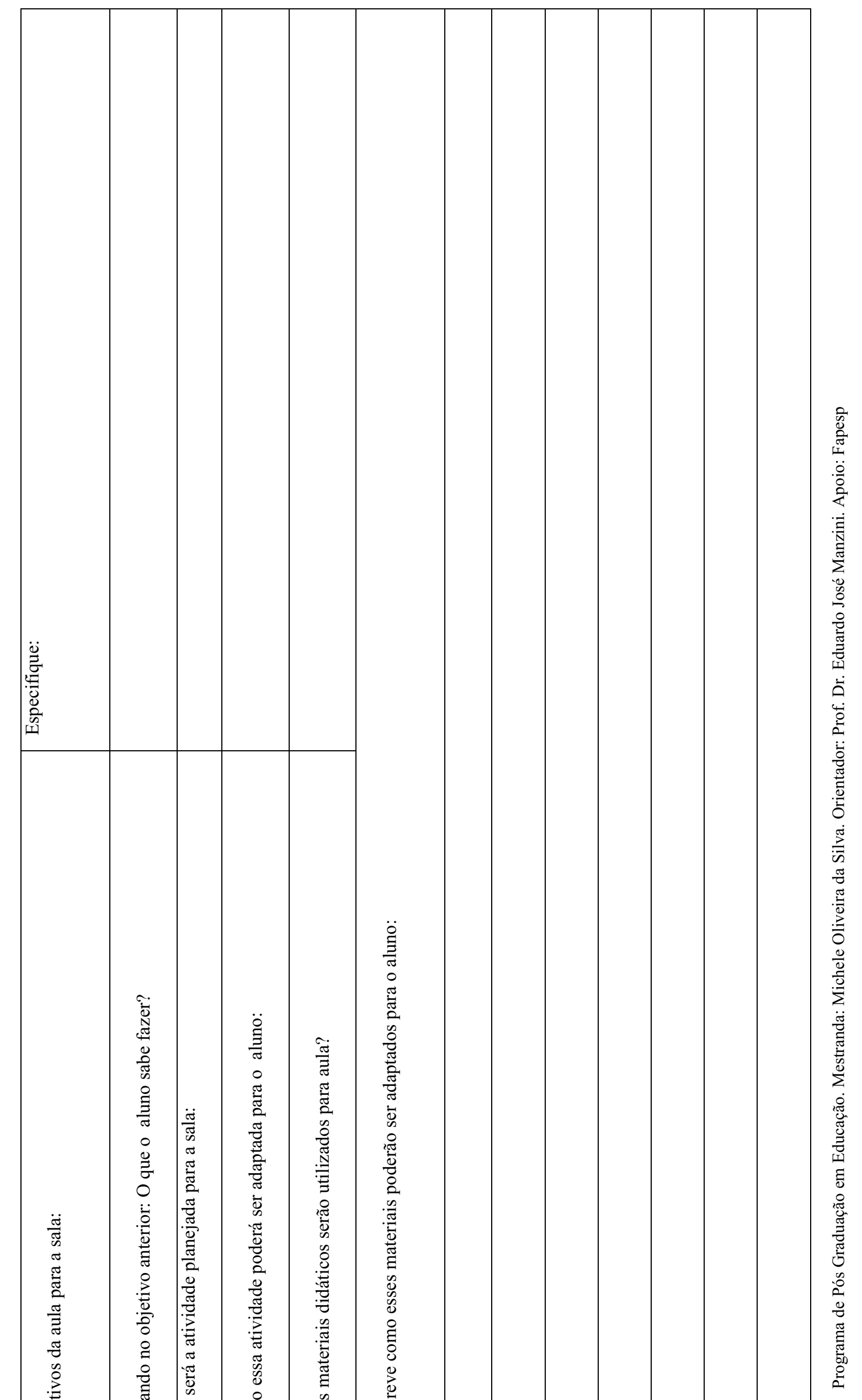




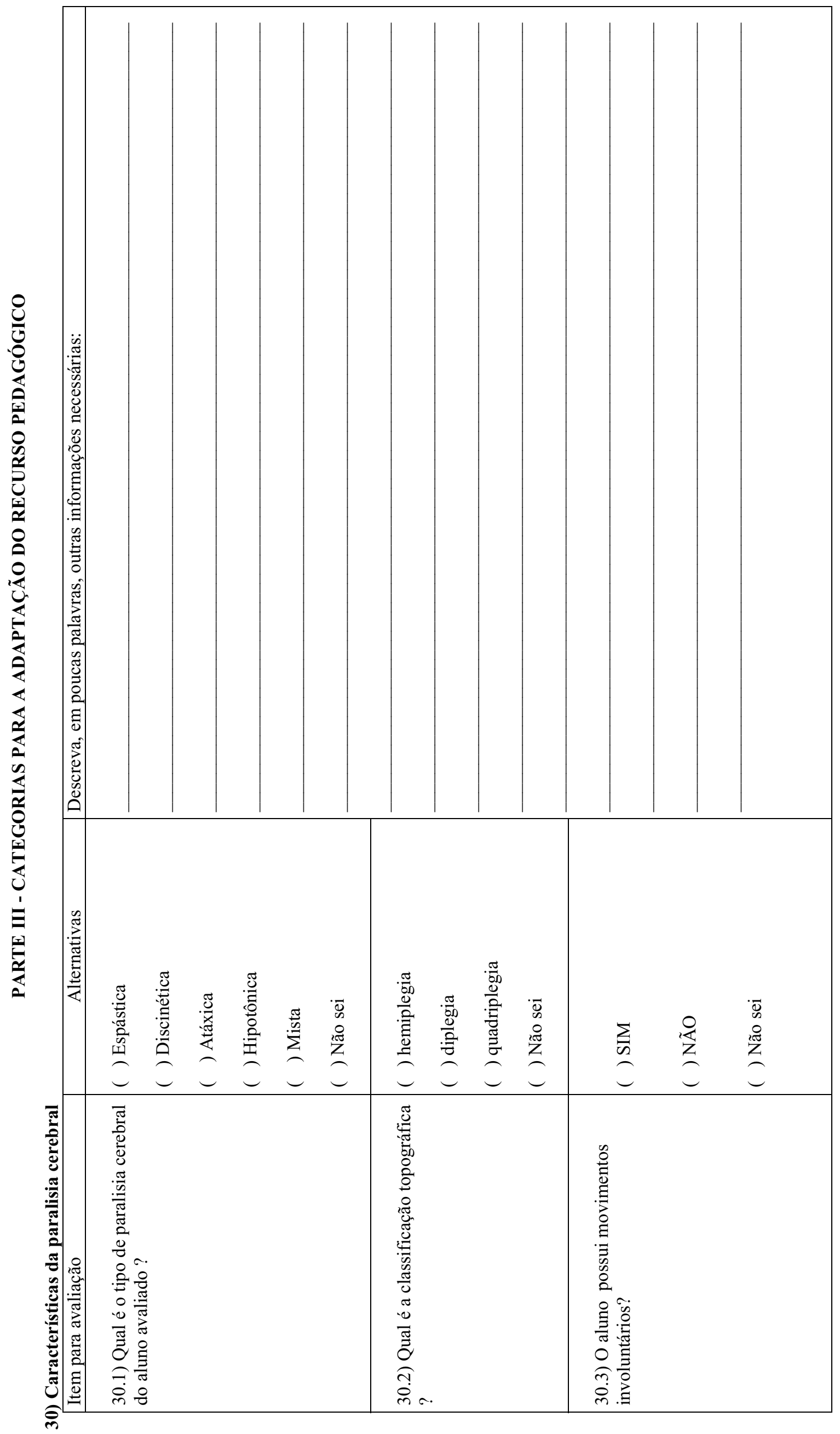

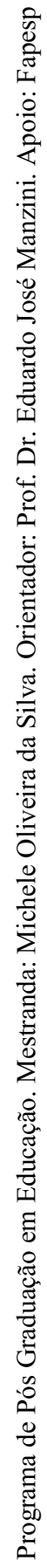




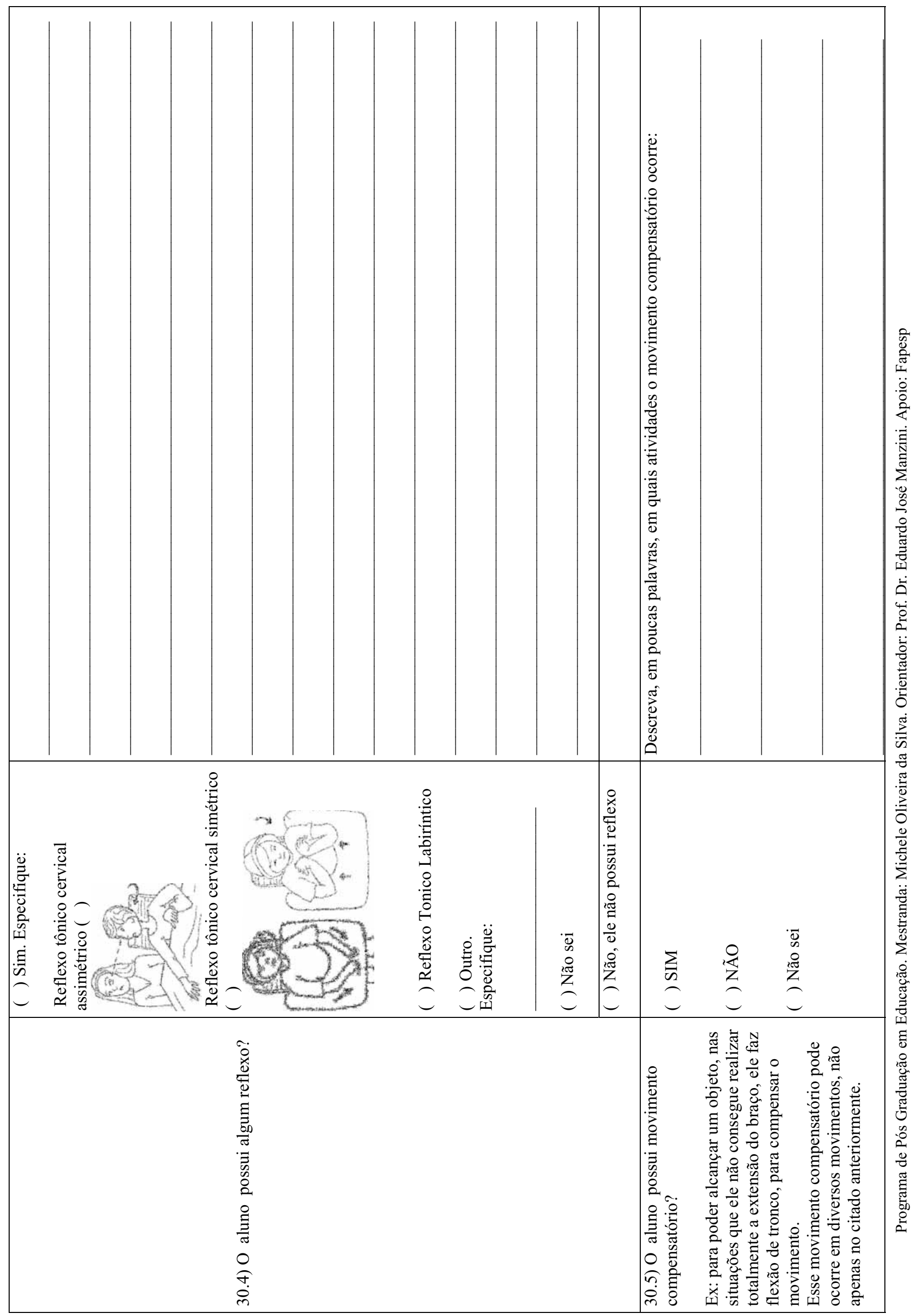




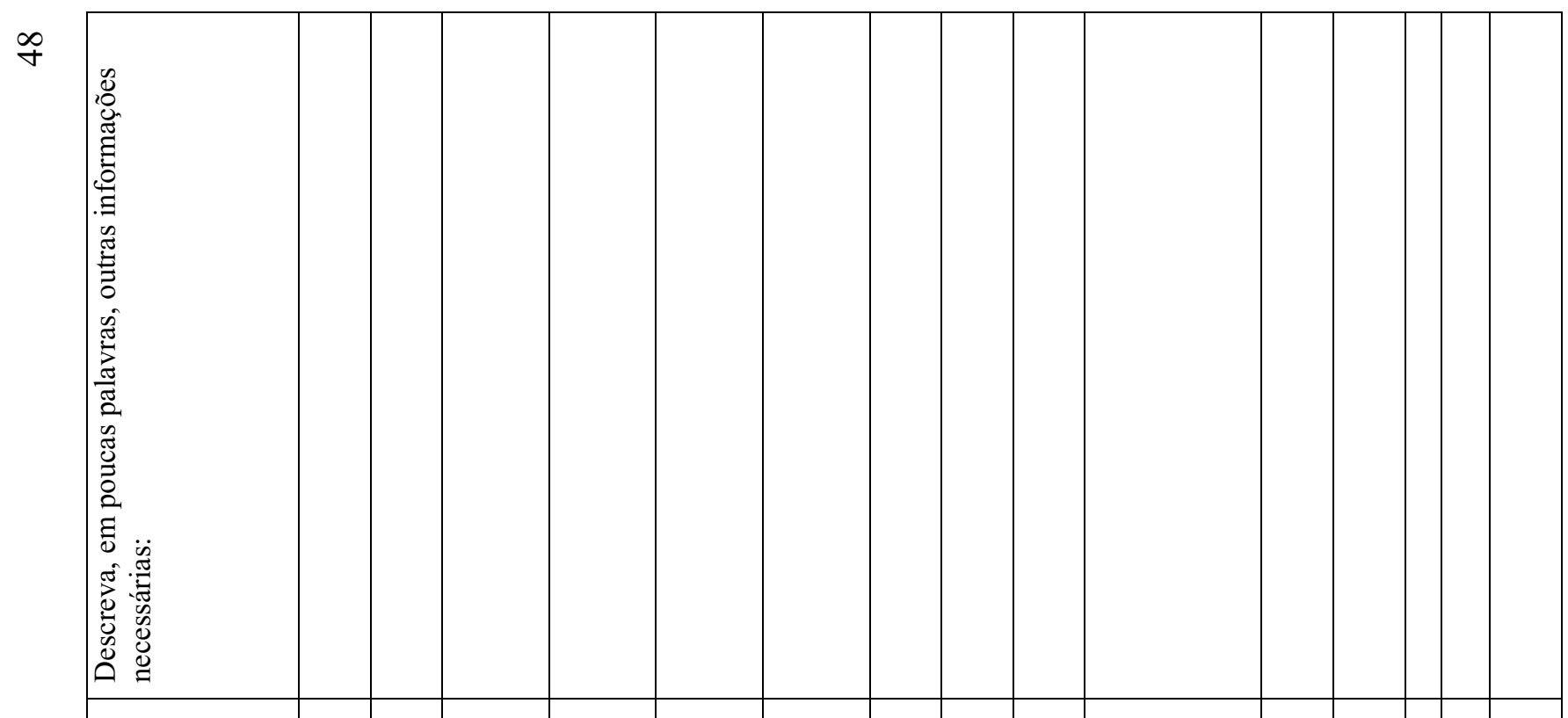

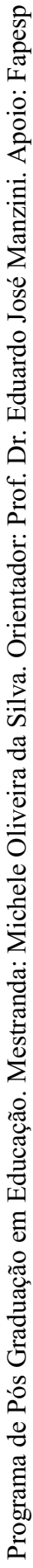



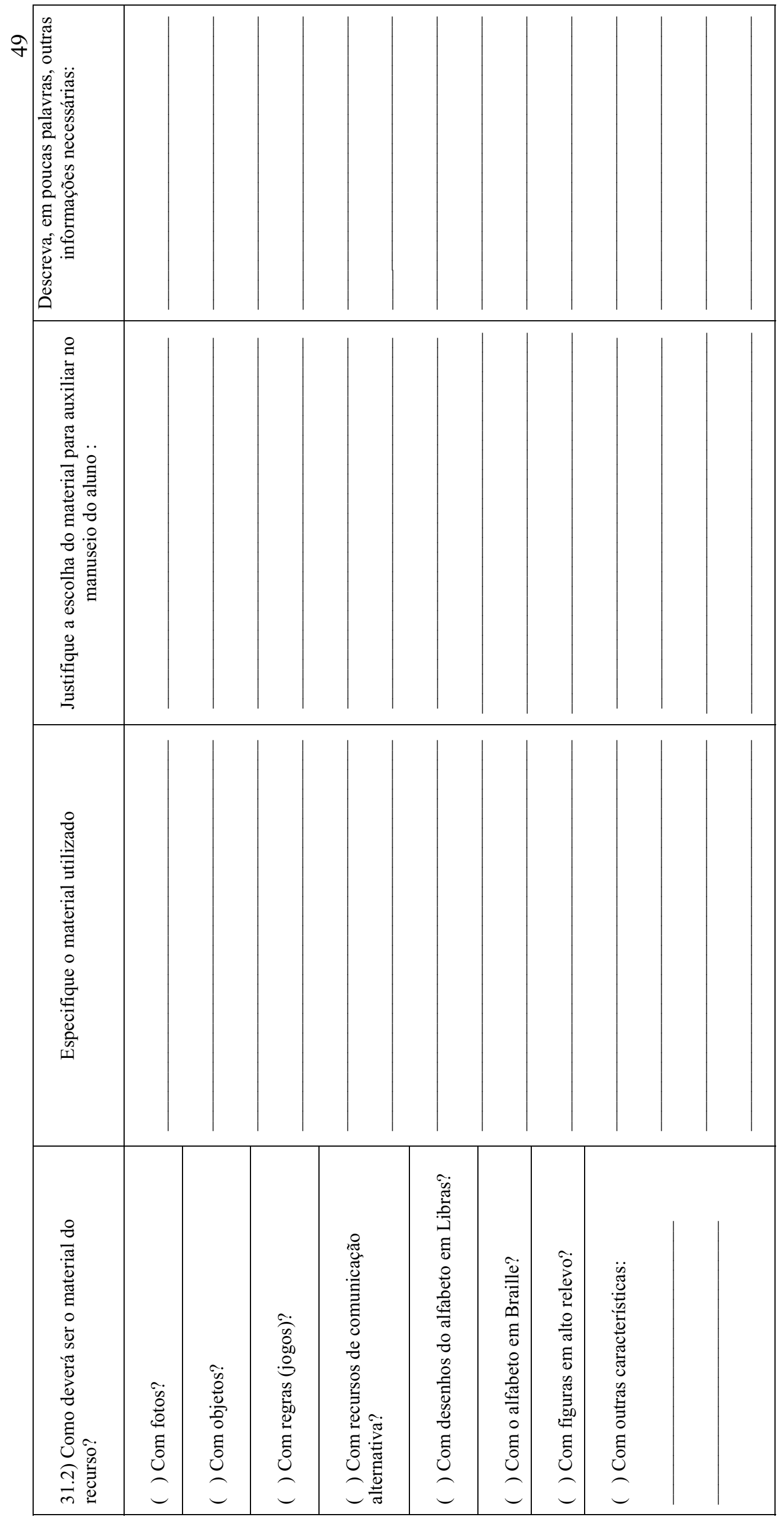

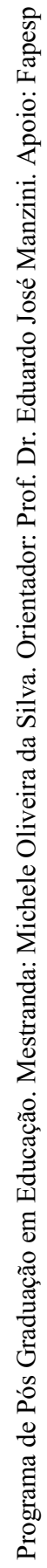


in

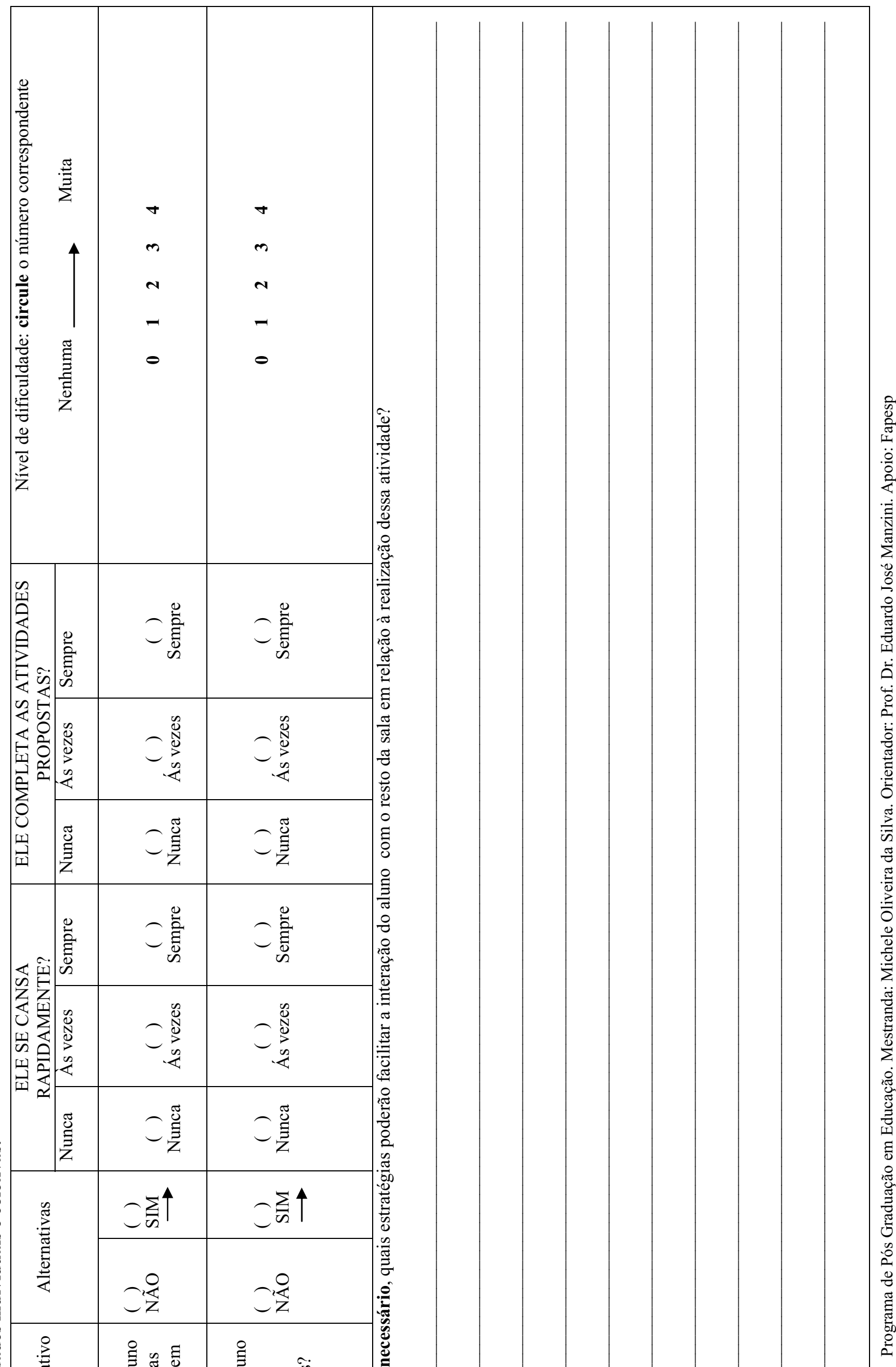

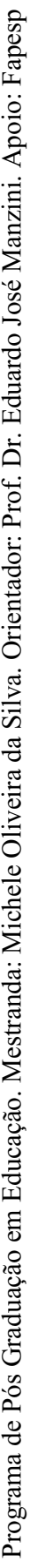




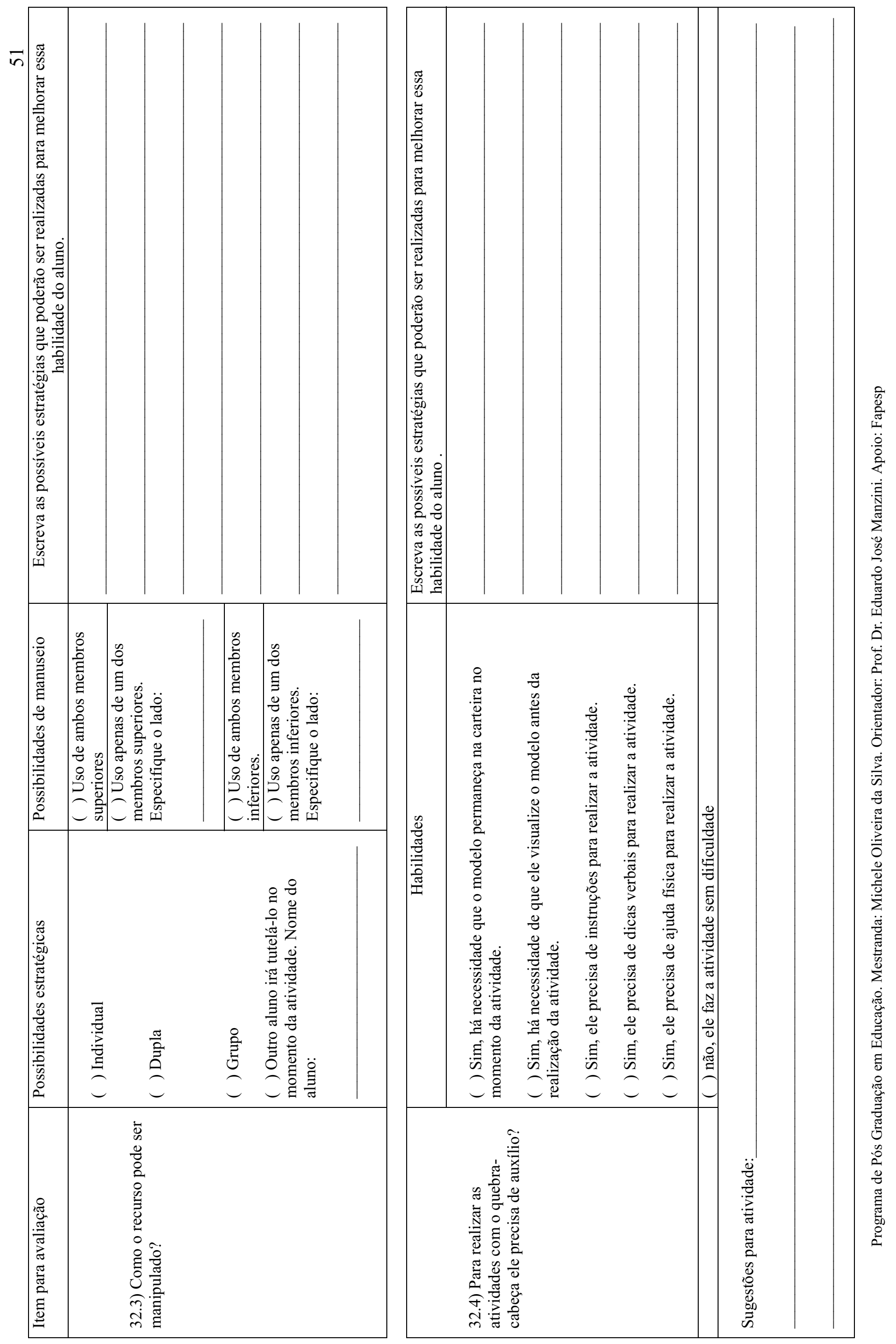




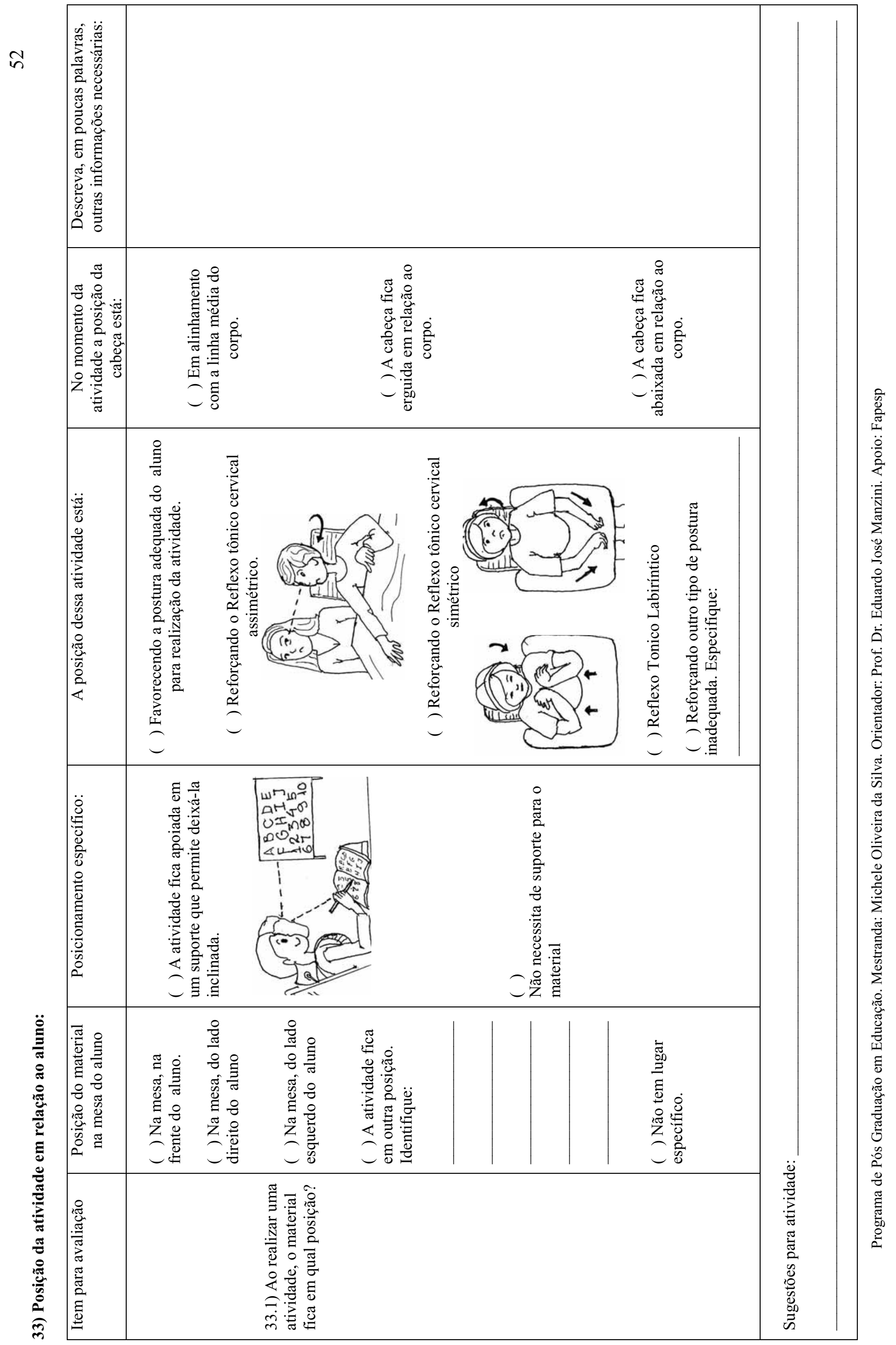


